\title{
Chinese Statistics: Output Data
}

China is the world's second-largest economy and its output data are being closely watched. The release of the latest GDP data by China's National Bureau of Statistics can be felt on stock markets around the globe, and may influence a broad range of economic decisions ranging from companies' investment strategies to monetary policy.

But China's GDP data are poorly understood. GDP in one year may be revised upward by 16.8 percent, while rural household consumption falls by 26.6 percent and government consumption rises by 41.1 percent. Data series appear to be revised every few years, even outside official benchmark revisions. The labor share in income is retrospectively revised to fall by more than 10 percent, and a few years later it is raised back to near its original level. Nominal data are retrospectively revised when an economic census newly discovers previously uncounted economic activities in the census year, but real growth rates are not retrospectively revised, implying a revised deflator for periods many years earlier. Data series end while series with similarly sounding labels newly start. The list is long. But explanations of what is happening to the data are almost always missing.

This manuscript first specifies what official data are available for

- GDP, including sectoral value-added, with a subsector breakdown for the tertiary sector as well as for industry (in the latter case limited to certain types of enterprises),

- aggregate expenditures, including the different types of expenditures, and

- national income, including income components.

It then proceeds to examine the quality of these data: it explains statistical breaks, resolves inconsistencies to the extent possible, and describes the limitations of different series. Third, it recommends particular output series for use in economic analysis and provides these data.

Journal of Economic Literature classification codes. all China:

C82 Data Collection and Data Estimation Methodology; Computer Programs - Methodology for Collecting, Estimating, and Organizing Macroeconomic Data

R1 General Regional Economics

P27 Socialist Systems and Transitional Economies - Performance and Prospects

O53 Economywide Country Studies - Asia including Middle East

Keywords (all: China): national income accounting; compilation of GDP and value-added, aggregate expenditures, and national income; national statistical system.

Carsten A. Holz cholz@stanford.edu

Stanford Center for International Development Stanford University 366 Galvez Street, Stanford, CA 94305-6015 


\section{Contents}

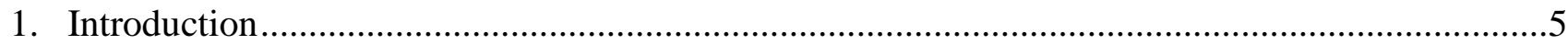

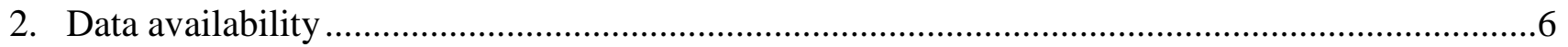

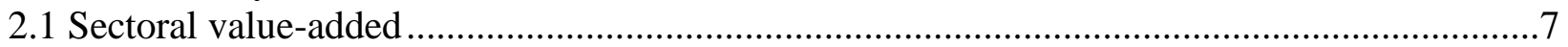

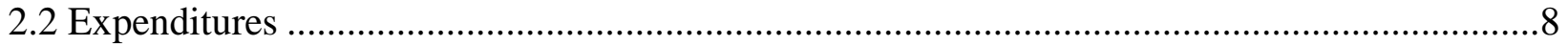

2.3 Income

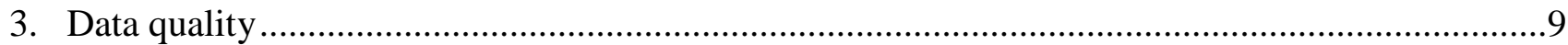

3.1 Comparison of the results of the three approaches to the calculation of GDP .....................10

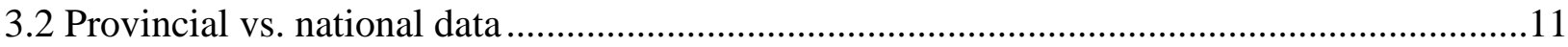

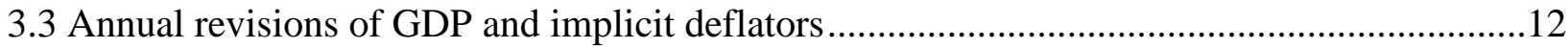

3.4 1995 benchmark revision of NIPA data following the 1993 tertiary sector census ................14

3.51996 benchmark revision of industry data following the industrial sector census 1995 and of agriculture data following the agricultural censuses of 1996 and 2006................................14

3.6 2006 benchmark revision of NIPA data following the 2004 economic census ......................14

3.6.1 Nominal 2006 benchmark revision values vs. earlier published values ......................15

3.6.2 National nominal 2006 benchmark revision values vs. original provincial values.......16

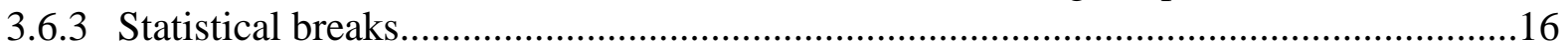

3.6.4 Benchmark revision real growth rates...............................................................17

3.6.5 Benchmark revision of expenditure data...........................................................20

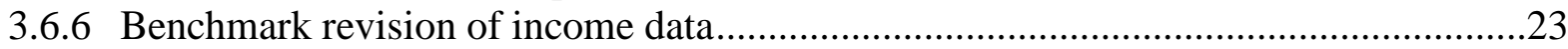

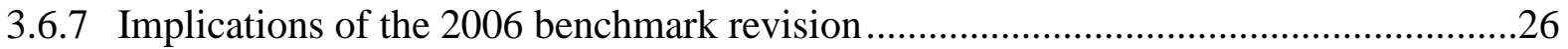

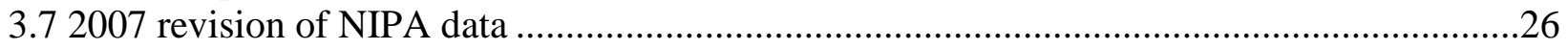

3.82010 benchmark revision of NIPA data following the 2008 economic census ......................27

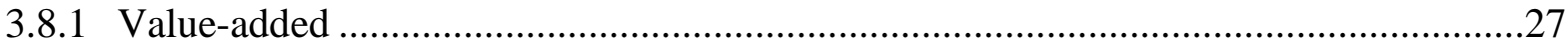

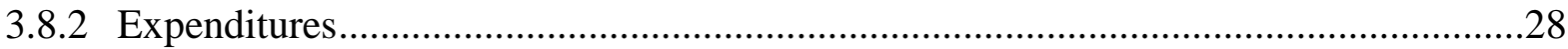

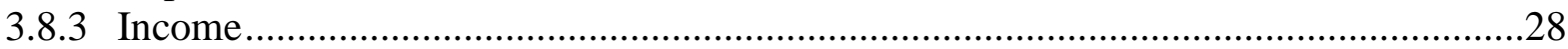

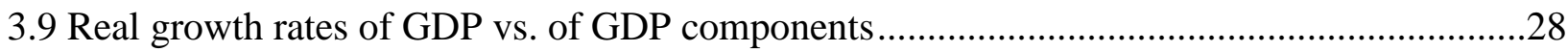

3.10 GDP deflator and NBS compilation of sectoral real output .........................................30

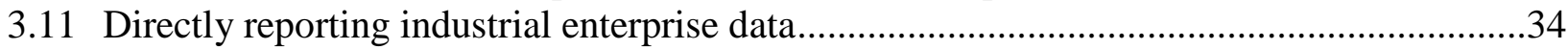

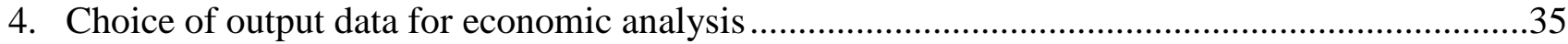

4.1 GDP and value-added of the three main economic sectors ................................................35

4.1.1 Published prior to the 2006 benchmark revision.......................................................35

4.1.2 Published after the 2006 benchmark revision .....................................................36

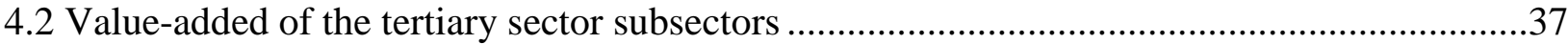

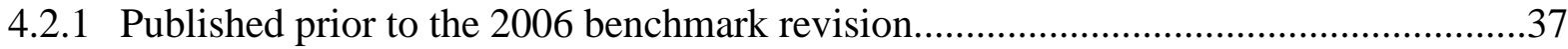

4.2.2 Published after the 2006 benchmark revision .......................................................39

4.2.3 Summary of tertiary sector sub-sector data availability...........................................39

4.3 Value-added of the directly reporting industrial enterprises............................................39

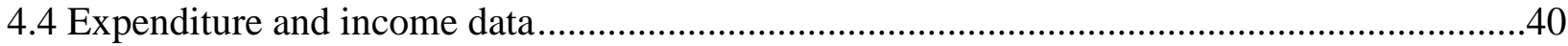

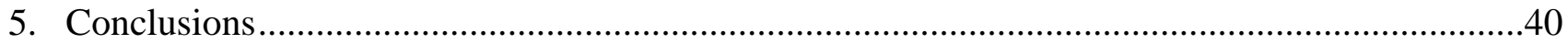




\section{Tables}

Table 1. Value-Added, Expenditures, Income: Key Data Sources and Their Coverage .....42

Table 2. Three Approaches to the Calculation of GDP (values in \%) ...............................44

Table 3. $\quad$ Summed Provincial Value-Added Divided by National Value-Added ....................46

Table 4. Annual Revisions to National Value-Added....................................................48

Table 5. $\quad$ GDP Real Growth Rates (in \%) .................................................................50

Table 6. $\quad$ Pre- versus Post-Economic Census 2004 Nominal Value-Added for 1978-2004.51

Table 7. Ratio of Post- to Pre-Economic Census Expenditure Values ...............................54

Table 8. Real Growth Rates and Implicit Deflators of Expenditures, Post- Vs. Pre-

Economic Census.............................................................................................56

Table 9. Real Growth Rates and Implicit Deflators of Aggregate Vs. Per Capita Household

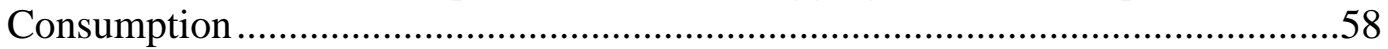

Table 10. Post- Vs. Pre-Economic Census Income Values, National and Selected Provinces,

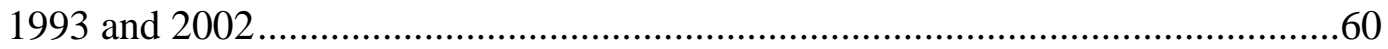

Table 11. $\quad$ Pre- and Post-Economic Census 2008 Value-Added........................................62

Table 12. Post- versus Pre-Economic Census 2008 Expenditures (percentage difference) ..63

Table 13. Official GDP Real Growth Rate Less (Various Versions of) the Weighted Sum of the Sectoral Real Growth Rates ....................................................................64

Table 14. Deflators for Industrial Output...................................................................66

Table 15. $\quad$ Expenditure Deflators and Price Indices.......................................................71

\section{Figures}

Figure 1. Nominal GDP: Production Value-Added Divided by Expenditure Value ...........45

Figure 2. $\quad$ Pre- and Post-Economic Census 2004 GDP, 1992-2004....................................53

Figure 3. Ratio of Post- to Pre-Economic Census Population Numbers Implicit in Aggregate and Per Capita Household Consumption Values ................................55

Figure 4. Shares of Individual Components in Income Approach GDP ............................59

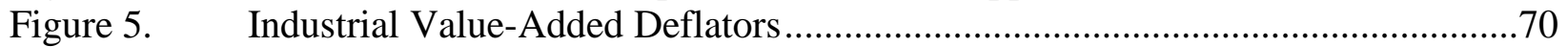

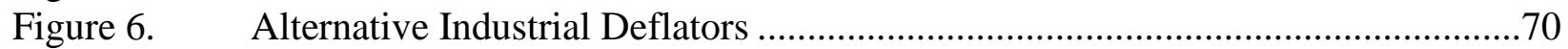

\section{Appendices}

Appendix 1. Nominal GDP and Sectoral Value-Added, 1952-2005 (b yuan, pre-GB2002, preand post-economic census 2004) ................................................................75

Appendix 2. Real Growth Rates of GDP and Sectoral Value-Added, 1953-2005 (annual, in \%, pre-GB2002, pre- and post-economic census 2004) ...........................................77

Appendix 3. GDP and Sectoral Value-Added, 1952-2011, Nominal Values and Real Growth Rates, GB2002, Post-economic Census 2004, 2008........................................79

Appendix 4. Implicit Deflators As First Published and Corresponding Real Growth Rates,

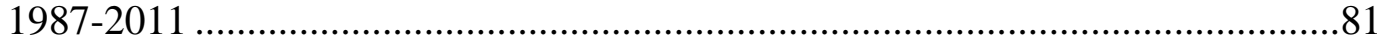

Appendix 5. Tertiary Sector Nominal Value-Added and Real Growth Rates, 1952-1995 (GB1984 with adjustments). 
Appendix 6. Tertiary Sector Nominal Value-Added and Real Growth Rates, 1990-2003 (GB1994), Pre-Economic Census 2004 ..........................................................87

Appendix 7. Tertiary Sector Value-Added, 2004-2010 (b yuan, GB2002), Post-Economic

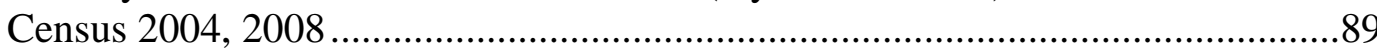

Appendix 8. Tertiary Sector Nominal Value-Added and Real Growth Rates, 1952-2011, GB2002, Post-economic Census 2004, 2008.....................................................90

Appendix 9. Directly Reporting Industrial Enterprise Output Measures 1993-2002 (b yuan) ..92 Appendix 10. Directly Reporting Industrial Enterprise Value-added 2003-2007 (b yuan) ..........96 Appendix 11. Directly Reporting Industrial Enterprise Gross Output Value 2003-2011 (b yuan)97 Appendix 12. Ex-Factory Price Index (Producer Price Index) by Industrial Sector (in \%), 20022011 .99

Appendix 13. Aggregate Expenditures and Real Growth Rates................................................101

Appendix 14. Economy-wide Income (b yuan). 


\title{
Chinese Statistics: Output Data
}

\author{
Carsten A. Holz
}

\section{INTRODUCTION}

The output measure examined in this manuscript is value-added, i.e., GDP at the national level, or regional gross value-added ("provincial GDP") at the provincial level. Both nominal and real growth series are covered, and a detailed sectoral breakdown is provided for the three main economic sectors, the directly reporting industrial enterprises (DRIEs), and the tertiary sector subsectors. GDP is the output series most closely watched by policymakers and the public

Aggregate expenditures and income, both with a breakdown into their major components, are also discussed. By definition GDP equals aggregate expenditures as well as income. Expenditure and income data are often of separate interest in economic analysis. For example, data on consumption vs. gross fixed capital formation can inform the debate on macroeconomic "imbalances" within China. Income data such as on the labor vs. profit share can inform a discussion of the attractiveness of China as a location for foreign direct investment.

The only potentially possible alternative to the output variable value-added (and expenditures and income) is gross output value. Data on gross output value are very scarce in comparison to the value-added, expenditure, and income data compiled as part of China's National Income and Product Accounts (NIPA). The variable gross output value is not further pursued here.

Value-added reported by sector follows the particular sectoral classification system in use at the time. China's sectoral classification system changed four times in the reform period:

- Prior to 1984, the NBS used a classification system that had not been formally approved by China's authority in charge of standards.

- The first formal classification standard (GB, guobiao) was issued in 1984, labeled GB/T4754-1984 (in the following abbreviated "GB1984”).

- GB1984 was revised in 1994 (GB/T4754-1994, or "GB1994”), following a trial revision in 1992.

- In 2002, GB2002 was issued (GB/T4754-2002, “GB2002”).

- In 2011, GB2011 was issued (GB/T4754-2011, “GB2011”).

The impact of changes to the sectoral classification system on the allocation of value-added to the three economic sectors (primary, secondary, tertiary sector), as well as to industry vs. construction within the secondary sector, is small. One particular instance where it matters is pointed out below. Changes to the sectoral classification system have a significant impact for some tertiary sector subsectors. ${ }^{1}$

The manuscript proceeds in three stages. The second section outlines data availability. The third section focuses on data quality, explaining statistical breaks, resolving inconsistencies to the extent possible, and describing the limitations of different output series. In the fourth section, particular output series for use in economic analysis are provided. The most recent data considered, when available, are of 2011. 


\section{DATA AVAILABILITY}

Prior to the reform period and through 1992, China's NIPA followed the Material Product System (MPS) with its coverage of material production only. In 1988, the NBS began to provide a basic set of NIPA data in accordance with the United Nation's System of National Accounts (SNA), at first with data on gross national product (GNP) and primary, secondary, and tertiary sector value-added going back to 1978. For 1992, the NBS reported a more detailed set of GDP data. Starting with the 1993 data, the NBS adopted the 1993 version of the SNA (with minor and, over time, decreasing deviations in the Chinese case) and abandoned the MPS. ${ }^{2}$ Output data in accordance with the SNA were compiled retrospectively for the years 1952-77 and first became available in GDP 1952-95 (which covers all years 1952-1995) and then in GDP 1952-2004. ${ }^{3}$

Data on value-added are available in the (national) annual Statistical Yearbook, starting with the 1988 issue, and in the three compendia GDP 1952-95, GDP 1996-2002, and GDP 1952-2004. The latter incorporates the 2006 benchmark revision of 1993-2004 data following the 2004 economic census. ${ }^{4}$ With the publication of GDP 1952-2004, the earlier publications became redundant for most but not all national data since 1952 and for provincial data since $1993 .{ }^{5}$ For specific sectors or subsectors, corresponding yearbooks may be available; for the case of industry, this is the Industrial Yearbook.

Each Statistical Yearbook issue contains provincial-level NIPA data for the current year (and sometimes the provincial GDP values of a few earlier years). Since the late 1980s, each province has also been publishing its own provincial annual statistical yearbook. Each issue of a province's statistical yearbook tends to provide more provincial time series data than the national annual Statistical Yearbook does. Data published in the provincial statistical yearbooks typically match those reported in the other sources, apart from occasional revisions. ${ }^{6}$

Four further sources contain national and provincial output data with limited sectoral coverage and limited coverage of the different approaches to calculating GDP. These sources are Seventeen Years, Fifty Years, Fifty-five Years, and Sixty Years. Apart from the more limited coverage, data reported in these compendia come without definitions of variables and without notes that flag changes in the definitions of variables over time. Only the most recent issue, Sixty Years, incorporates the 2006 benchmark revision of 1978/1993-2004 data, but still not the 2010 benchmark revision, affecting the years 2005-2008 (and in the expenditure approach the years 2001-2004, also). The subsequent discussion of output data does not consult these compendia except for the most recent one when it provides a long data series not found in this completeness elsewhere.

Table 1 summarizes the data coverage of the key sources for Chinese NIPA data compiled and published in accordance with the SNA. The NBS's calculation of China's GDP values officially follows the production approach. In practice, this means that the production approach is used in some sectors (such as agriculture and industry) and supplemented by the income approach in others (some service subsectors). ${ }^{7}$

[Table 1 about here]

The 2004 economic census in 2006 led to an extensive benchmark revision of NIPA data for 1993-2004 (and extending back to 1978 for some variables). In comparison, the 2010 benchmark revision following the 2008 economic census comprised only minor revisions, for 2005-2008 (and in the expenditure approach also 2001-2004). The 2006 benchmark revision raises a number of questions and is discussed in detail below. 
Most of the more recent NBS data publications come with a CD that contains Excel files of the tables in the publication. Often, data in the Excel files are reported with more decimals than in the hard copy publication. This may make a difference when numbers are in the single digits. The data checks conducted below typically use the data on the CD if a CD is available. When these data go through manipulations and are then compared to a print series, small differences could simply be due to rounding in the print series.

\section{$2.1 \quad$ Sectoral value-added}

The production approach to the calculation of value-added proceeds sector by sector. In each sector, value-added equals gross output value (GOV) less intermediate inputs, plus, since 1995, the value-added tax. (Prior to 1995, a then minor value-added tax was already included in GOV and thus did not have to be added; it has not been included in GOV since 1995.) For several tertiary sector subsectors, the NBS substitutes income approach data for value-added. Economywide, production approach GDP equals the sum of value-added across the three main economic sectors: the primary, secondary, and tertiary sectors.

The Statistical Yearbook of each year (starting with varying details in the 1988/1990/1991 issues) publishes nominal national data and real growth rates for the previous year and all earlier years since 1978 (real growth rates since 1979). It also publishes the nominal provincial data for the previous year and sometimes provincial nominal GDP and real GDP growth rates of several previous years. The typical coverage comprises the primary sector, the secondary sector (with separate data on the two exhaustive subsectors of industry and construction), and the tertiary sector. Through 2006, separate data are available on two non-exhaustive tertiary sector subsectors: 'transport and communication' and 'commerce and catering.' The 1998 and 1999 issues, exceptionally, report national data going back to 1952-1953.

Separately, GDP 1952-95 covers GOV and value-added of the main economic sectors for 1952-1995, at the national and provincial levels, including both nominal values and real growth rates (since 1953). Besides the secondary sector breakdown into industry and construction, GDP 1952-95 also offers data on eight exhaustive tertiary sector subsectors (but for these latter only value-added data). GDP 1996-2002, similarly, covers the years 1996-2002 with occasionally

additional values for some earlier years. ${ }^{8}$ The sectoral classification in these publications largely follows GB1994. GDP 1952-2004 reports GDP (but not GOV) of the main economic sectors at the national level for all years since 1952 and incorporates the 2006 benchmark revision. It follows GB2002. The subsectoral coverage extends to the two secondary sector subsectors of industry and construction and to six exhaustive tertiary sector subsectors. Provincial-level data on GOV and GDP cover the years 1993-2004 and follow GB1994; the coverage of tertiary sector subsectors is limited to five. Sixty Years reports nominal values and real growth rates following GB2002 for 1952-2008 (including on industry, construction, and the two tertiary sector subsectors 'transport, storage, and post' and 'wholesale and retail trade').

For the tertiary sector, a more detailed classification with 13 subsectors is available in the Statistical Yearbook, at the national level, for 1990-2003 following GB1994 but with an additional category "agricultural services.” Not every issue repeats the nominal values and real growth rates of all earlier years and publication occurs with an extra year time lag (year t values are published in Statistical Yearbook t+2). GDP 1952-95 covers an exhaustive 12 subsectors, following an adjusted GB1984, also with data only for the years since 1990, while GDP 19962002 covers an exhaustive 13 subsectors for 1996-2002 (in slight variation of GB1994, also 
including "agricultural services"). These compendia include the corresponding provincial-level data. All data are pre-economic census values. GDP 1952-2004 provides the full post-economic census 14-sector breakdown of the tertiary sector following GB2002, for 2004 only, and only at the national level; the Statistical Yearbook 2007 and subsequent issues continue with the 2005 and subsequent data.

The industry section of each issue of the Statistical Yearbook reports output values of the directly reporting industrial enterprises (DRIEs) for the previous year by individual industrial sector. Output data typically comprise value-added starting with data for the year 1992 (net material product for 1992 and earlier years) and GOV. ${ }^{9}$ The Statistical Yearbook also reports provincial DRIE output values of the previous year. Publication of DRIE value-added data ends with the 2007 values.

The Industrial Yearbook series reports similar national data by industrial sector but also provincial data by industrial sector (no 1996 and 2004 data are available). Apart from valueadded (through 2007) and GOV, the Industrial Yearbook series also reports GOV at constant prices for the years through 2003 (except for 1998). The Industrial Census 1995 has these data for 1995; the Economic Census 2004 and 2008 volumes only report GOV. The provincial statistical yearbooks typically report the previous year's provincial output values of the DRIEs by industrial sector; the degree of completeness of the statistics varies from province to province. The 2006 benchmark revision did not lead to a revision of DRIE data, presumably because these data have always been accurate to begin with. ${ }^{10}$

\section{$2.2 \quad$ Expenditures}

In the expenditure approach to the calculation of GDP, GDP equals the sum of consumption (household and government consumption), gross capital formation (gross fixed capital formation and inventory investment), and exports, less imports. The Statistical Yearbook beginning with the 1995 issue reports the nominal values of these expenditure items for the years since 1978 (but not for 1996). Export and import data are only available in form of net exports. The Statistical Yearbook does not report real growth rates, except for per capita household consumption (with a breakdown into rural and urban).

GDP 1952-95 reports national nominal data and real growth rates for consumption and gross capital formation with detailed breakdowns for the years 1952/53-1995, but no data on total expenditures or exports. ${ }^{11}$ GDP 1996-2002 further includes nominal values of total expenditures and net exports; it also has real growth rates of household consumption (rural/urban), government consumption and gross capital formation (gross fixed capital formation and inventory investment) for 1979-2002. GDP 1952-2004, incorporating the 2006 benchmark revision, reports nominal values of total expenditures, household consumption (urban/rural), government consumption, gross capital formation (gross fixed capital formation and inventory investment), and net exports for 1952-2004; real growth rates are again not available for total expenditures and for net exports, but for consumption (with its breakdown into household, including rural vs. urban, and government) and for gross capital formation (with its breakdown into gross fixed capital formation and inventory changes), for 1953-2004. Sixty Years reports national expenditure approach nominal values incorporating the 2006 benchmark revisions for 1952-2008.

GDP 1952-95 offers a further breakdown of rural and, separately, urban household consumption nominal values by consumption category, GDP 1996-2002 does so only in the 
provincial data, while GDP 1952-2004 offers no breakdown. Starting with the Statistical Yearbook 2007, the Statistical Yearbook series reports rural and urban household consumption values by consumption category for one or two to four earlier years.

At the provincial level, besides data on consumption and gross capital formation, GDP 195295 typically also reports total expenditures and net exports (for some provinces in some years with a breakdown into imports and exports), but not real growth rates for total expenditures and for net exports. Most provinces set total expenditures equal to the summed sectoral value-added in the production approach and obtain net exports as summed sectoral value-added less consumption and gross capital formation. GDP 1996-2002, for 1996-2002, provides the same coverage and follows the same practices. ${ }^{12}$ The same type of provincial data, now revised in the 2006 benchmark revision, are reported in GDP 1952-2004 for 1993-2004, but without separate provincial export and import values, and without explanation of the data compilation practices. Sixty Years reports provincial expenditure approach nominal values incorporating the 2006 benchmark revisions, for 1952-2008.

\section{$2.3 \quad$ Income}

In the income approach to the calculation of GDP, GDP equals the sum of labor remuneration (with an official label "compensation of employees"), depreciation, net taxes on production, and operating surplus. No national data are available; what are available are provincial nominal data.

The Statistical Yearbook series, starting with the 1995 issue, reports the (provincial nominal) data of two years earlier, and more recently, of the previous year. (Data for 1995, 2004, and 2008 are missing.) GDP 1952-95 and GDP 1996-2002 report the provincial nominal data for the years since 1978, province-wide, as well as by main economic sector within each province (with the secondary sector breakdown into industry and construction and a 10/12 subsector breakdown of the tertiary sector). GDP 1952-2004 has the data for the years 1993-2004, with revised values in the overlapping years, but provides only a five-sector breakdown of the tertiary sector (following GB1994).

National data could be pieced together independently from two sources: input-output tables and flow of funds tables. Input-output tables are only published in five-year intervals (with the occasional table in between). Flow of funds tables are available since 1992. Bai Chong-en and Qian Zhenjie (2009) report that the long-term trends and the relative changes over time of the income components are similar across all three data sources. The provincial data provide the longest time series.

\section{DATA QUALITY}

This section discusses five aspects of data quality. First, to what extent are the official GDP values corroborated through identical results of different methods of calculating GDP and by GDP values calculated as the sum of provincial values? Second, what do the regular annual revisions reveal about the reliability of the published GDP data? Third, what is the extent and size of the various benchmark revisions that the NBS has undertaken at different points in time? Fourth, how does the NBS obtain the real growth rate of the official GDP value from the 
underlying sectoral data, and to what extent does the real growth rate depend on the choice of (implicit) GDP deflator? A final subsection discusses the quality of the data on DRIEs.

\subsection{Comparison of the results of the three approaches to the calculation of GDP}

Theoretically, the three approaches to the calculation of GDP should yield identical results. But none of the three approaches is perfect. The problems range from the imputation of the rental value of owner-occupied housing to the calculation of depreciation and the compilation of data on labor remuneration.

With income data available at the provincial level only, comparisons of GDP obtained according to the three different approaches to calculating GDP are best conducted at the provincial level. Table 2 provides a comparison of provincial GDP, calculated according to the three approaches, in the years 1993 (the first year for which the Statistical Yearbook reported provincial expenditures and income), 1995, 2000, 2003, and 2007 (with post-economic census 2004 data used only for 2007). In 1993, aggregate value-added (production approach GDP) equals aggregate expenditures (expenditure approach GDP) in almost all provinces and equals income in all provinces. In subsequent years, value-added and income continue to be identical across all provinces, while expenditures in 1995 differed in about one-third of all provinces and in fewer provinces in the subsequent years. ${ }^{13}$ The 2010 pattern (not reported in the table is virtually identical to that of 2007). ${ }^{14}$

[Table 2 about here]

When provincial GDP values are equal across two if not all three approaches to the calculation of GDP, provincial statistics offices presumably calculate some expenditure and income items as residuals. GDP 1952-95 and 1996-2002 say as much: for "most provinces," net exports (to other provinces and other countries) are obtained as residual.

At the national level, aggregate value-added can be up to five percent lower and up to three percent higher than aggregate expenditures. Figure 1 shows the ratio of these two values using two different sets of data, one consisting of first published data, the second of data published in the Statistical Yearbook 2012 (incorporating all benchmark revisions for all years). The ratios do not follow any systematic pattern except that there seems to be a tendency for aggregate valueadded to be slightly lower than aggregate expenditures.

[Figure 1 about here]

A closer examination of the expenditure approach reveals that NBS explanations on how household consumption is calculated are not consistent across different NBS sources. This matters because household consumption accounts for approximately one-half of expenditure approach GDP. Reconstructing household consumption values according to the official explanations of how the NBS compiles these data does not lead to values that match the official data. The gap between the reconstructed and the official data is often substantial (several percentage points), but not systematic over time. ${ }^{15}$

When the NBS announces GDP values to the media, it reports the production approach data, supplemented or replaced in some sectors by income data. These are regarded as the official values. The focus on the production approach can be traced back to the use of the MPS in statistical accounting prior to the reform period and into the late 1980s. The MPS relies on the sectoral calculation of output values. The sum of the separately compiled expenditure values on consumption and accumulation, terms specifically defined in the MPS, is by definition not equivalent to aggregate output. 


\subsection{Provincial vs. national data}

National GDP should equal the sum of provincial GDP. But the sum of provincial GDP routinely exceeds national GDP. Table 3, for data as first published, shows the difference between the NBS's national GDP data and the summed provincial values for sectoral value-added and for expenditures. After 1996, in both approaches, summed provincial values increasingly exceed the NBS's national value. By 2004, summed provincial value-added was 19.3 percent larger than the national value reported by the NBS. The summed provincial values exceed the NBS's national values for the secondary sector and in particular for the tertiary sector. Revisions to national data following the 2004 economic census and the 2008 economic censuses lowered the discrepancy somewhat (see sections below), but it has never been fully eliminated. In the expenditure approach, the NBS through 2004 reports higher national household consumption than the summed provincial values, and lower values since then. Thoughout, the NBS reports lower national government consumption (very significantly lower through 2004) and significantly lower gross capital formation.

[Table 3 about here]

The increasing gap starting 1996 coincided with a wave of reports on local data falsification in 1997 through approximately 2001. In response, in 1997-1998, the NBS with support of the State Council and the Chinese Communist Party Central Committee's Disciplinary Commission started a campaign against local data falsification. The continuing difference between the national values and the summed provincial values would suggest that the campaign was not successful.

In 2004, the then NBS commissioner, Li Deshui, gave the following reasons for the discrepancy between national GDP and summed provincial value-added: provinces use 1990 base year prices when calculating industrial real growth, while the NBS makes adjustments to this procedure based on a price index (and starting in 2004 the NBS, for agriculture and industry, relies only on a a price index); provinces double-count cross-provincial economic activities; provinces still use (presumably questionable) report forms for industrial enterprises with annual sales revenue below $5 \mathrm{~m}$ yuan (non-DRIEs); provinces use the opportunity of the as yet incomplete measurement of tertiary sector activities to adjust tertiary sector output upward such that the sectoral data add up to their desired aggregate output value; and provinces have incentives to exaggerate output (due to growth targets, comparisons of different localities by their output growth rates, and the use of statistics to measure local cadres' "achievements").

To the extent that the NBS uses provincial data in deriving the national total, the question arises how the NBS adjusts provincial value-added data in deriving national GDP values. In February 2000, Liu Hong, the then NBS commissioner, offered two comments. The NBS contrasts provincial GDP data with key economic data obtained through sample surveys in each province. The NBS also has available data on variables related to GDP and assumes that the values of these variables cannot grow at a speed that is much different from that of GDP. ${ }^{16} \mathrm{Li}$ Deshui's 2004 reasoning on the differences suggests that, in addition, the NBS also considers a price index and survey data on small industrial enterprises, and controls against double-counting.

In the literature, some Chinese authors attribute the discrepancy to data falsification at lower tiers and to problems in calculating provincial-level, let alone municipal- and county-level GDP. In the production approach (supplemented by income data), alleged local exaggeration in the tertiary sector is attributed to a lack of local data, with nationwide data presumably collected through centrally organized, nationwide sample surveys. In the expenditure approach, local imports and exports, which at the local level include trade with other localities, are impossible to 
determine, and data on changes in inventories are supposedly highly incomplete since such data are only available for the directly reporting enterprises. ${ }^{17}$

Despite these arguments in favor of the national rather than the summed provincial data, the 2004 economic census with the subsequent 2006 benchmark revision to the GDP values of 19932004, discussed below, suggests that the provincial GDP values, and thereby summed provincial value-added, may in recent years - at least throughout the mid-2000s-have been more accurate than the national data.

\subsection{Annual revisions of GDP and implicit deflators}

The NBS retrospectively revises data in annual and in benchmark revisions. Every year, the NBS in the Statistical Yearbook provides a revised set of production approach nominal GDP and sectoral value-added for the last previously published annual data, and similarly for expenditures. For example, the Statistical Yearbook 2012, published in September 2012, provides (final) revised nominal GDP data for 2010 together with preliminary GDP data for the latest year, 2011. Year 2010 (production approach) GDP was revised upward by 0.1 percent. Prior to the publication of the Statistical Yearbook, the revised, final 2010 figure already appeared in the Statistical Abstract 2012, published in May 2012, which otherwise provided the first comprehensive data for 2011. Retrospective annual revisions that go back more than one year are rare; when they do occur, they are on a very minor scale, except in the Statistical Yearbook 1989 — in the very early years of the adoption of the SNA — where revisions went back several years and for some years reached a scale of about 3 percent.

The NBS reports nominal values (of current-price value-added, expenditures, and income) and real growth rates (of value-added and some expenditure categories, for the latter through 2004), but not deflators. An implicit deflator can be calculated by dividing the growth rate of the nominal values (1.X) by the real growth rate (1.Y).

While the nominal data of a particular year are revised in the next year's issue of the Statistical Yearbook, the real growth rates are typically not revised. Yet, in as far as the first published (implicit) sectoral deflators constitute the final estimates of the true deflators, they are applicable not only to the first published GDP data but also to the later revised nominal GDP data. $^{18}$

First published implicit deflators are likely to be the final ones because the revisions to nominal data are largely, if not exclusively, based on revised data from those statistical units that do not report directly to the NBS. The data collected from or guesstimated for these statistical units are likely to consist only of nominal data (no constant-price output values), in many instances not even of direct output measures but of related measures such as sales revenue. Deflators, in contrast, in most sectors, are derived by the NBS from data provided by the directly reporting statistical units. Such data are typically not revised later, i.e., the first data are final data. When the NBS uses price indices, such as for some subsectors of the tertiary sector, these are final by the time the NIPA data are first published in the Statistical Yearbook; the price indices published in the Statistical Yearbook have never been retrospectively revised. But if the first published (implicit) deflators of sectoral value-added are final, then later revisions to nominal value-added should trigger corresponding revisions to real growth rates, which, in practice, they usually do not.

If real GDP growth were derived from weighted sectoral growth rates using previous-year nominal sectoral shares or the Törnqvist index (which is not the official procedure, explained 
below), revisions to nominal sectoral data (the relative weights) may impact on real GDP growth. Changes to nominal sectoral data, thus, even if they were accompanied by changes of similar size to the sectoral deflator-which, as argued in the previous paragraph, is not plausible-could affect real GDP growth through changing weights as long as sectoral real growth rates are not identical.

Table 4 reports the annual revisions to nominal value-added and expenditures, ignoring the retrospective 2006 and 2010 benchmark revisions of several earlier years' values. Apart from the tertiary sector census year 1993 and the economic census years 2004 and 2008 (when the annual revisions coincided with the benchmark revisions), the annual retrospective revisions to GDP in most years were minor. The extremes are an upward correction to production approach GDP in 1994 of 3.9 percent, a downward correction to production approach GDP in 1998 of 1.3 percent, and downward corrections to 1995 and 1997 expenditure approach GDP by 1.6 and 1.5 percent. In individual sectors and expenditure categories the corrections can be slightly larger. The varying but often very large revisions to inventory investment (in the expenditure approach) either suggest considerable problems in obtaining accurate data on inventory investment, or reflect the derivation of inventory investment as residual. Because inventory investment since the mid-1990s accounts for a lower single-digit percentage share in GDP only, the impact of revisions to inventory investment on aggregate GDP is small.

[Table 4 about here]

The first column of Table 5, for the years 1987-2011, reports real GDP growth rates as first published. ${ }^{19}$ The second column reports real GDP growth rates as most recently published prior to the 2006 benchmark revision, in the Statistical Yearbook 2005; these values incorporate the benchmark revision following the 1993 tertiary sector census. Throughout the early 1990s, first and later published real GDP growth rates differ by up to approximately one percentage point. Between 1995 and 2003, real growth rates were rarely revised. The 2006 and 2010 benchmark revisions (reflected in the Statistical Yearbook issues of 2009 and 2012, third and fourth columns of Table 5) bring two further rounds of growth rate revisions (for 1993-2004 and 2005-2008), never more than one percentage point per year, except in 2006 and 2007 with 1.1 and 1.2 percentage points.

The last four columns of Table 5 report real GDP growth rates obtained by combining two sets of published nominal values with the deflators implicit in the first published (nominal and real) data. The two sets of nominal values are the pre-benchmark revision 2006 nominal values and the most recently published nominal values. Two methods are used to calculate these real growth rates: one is to deflate nominal GDP growth using the first published implicit GDP deflator, the second is to apply this method to the three main economic sectors, and to then aggregate the sectoral real growth rates using a Törnqvist index; the difference in outcome between these two methods is sufficiently minor to not warrant further attention.

The underlying assumption for the last four columns of Table 5 is that the first published implicit GDP deflators are correct, i.e., the annual revisions to nominal data should trigger similar revisions to real growth rates (which they usually do not). The resulting real growth rates for 1991-1994 are substantially different from those first published. The 1991-1993 difference can possibly be explained by the incorporation of tertiary sector census results in the more recent set of nominal data. It is also possible that in these years of large-scale price liberalization the implicit deflators are little more than haphazard guesses and that the NBS felt the revisions to nominal values more likely reflect previously poorly measured deflators than poorly measured real growth rates. 
In the subsequent years, the difference can reach up to close to two percentage points, with one exception: the derived real growth rate of 2007 is almost five percentage points higher than the first published one. Real growth in 2007 is 16.8 percent if the first published implicit deflator is used, compared to a first published real growth rate of 11.9 percent that was later raised to 14.2 percent. $^{20}$

[Table 5 about here]

\subsection{5 benchmark revision of NIPA data following the 1993 tertiary sector census}

Following the 1993 tertiary sector census, tertiary sector value-added for the years 1978-1993 was revised, and consequently so was GDP. The Statistical Yearbook 1995 and all subsequent issues of the Statistical Yearbook, as well as GDP 1952-95, incorporate the 1995 benchmark revision of tertiary sector value-added (and thereby also GDP) for the years 1978-1993. Tertiary sector value-added for 1993 was revised upward by 32.04 percent, and GDP was thereby revised upward by 9.99 percent. Tertiary sector value-added and GDP of all years back to 1978 were revised, with 1978 revisions of 4.37 percent and 1.00 percent, respectively. The real growth rates reported in the second data column of Table 5 (with data from the Statistical Yearbook 2005) for the years 1987-1993 reflect these revisions.

\subsection{6 benchmark revision of industry data following the industrial sector census 1995 and of agriculture data following the agricultural censuses of 1996 and 2006}

The industrial census of 1995 led to a downward revision of industrial GOV for 1991 through 1994 by 6, 7, 9 and 10 percent, respectively, in the Statistical Yearbook 1996 (p. 401). ${ }^{21}$ Yet, industrial value-added and GDP for these years were not retrospectively revised. This is plausible only if the value of intermediate inputs was revised downward in these four years by exactly the same absolute amount. Industry-wide census data on intermediate inputs are not available. $^{22}$

The agricultural census of 1996 appears to have had no impact on the value-added of the primary sector. The agricultural census of 2006 led to a retrospective 2.82 percent downward revision in the value-added of the primary sector in both 2005 and 2006, with a corresponding revision of GDP. The real growth rates of primary sector value-added in both years remained unchanged. $^{23}$

\subsection{6 benchmark revision of NIPA data following the 2004 economic census}

The "economic census" of 2004 led to a benchmark revision of NIPA data in 2006. This benchmark revision is of such size and of such importance in terms of innovations to data compilation methods that it is is discussed in some detail here.

The benchmark revision was announced by the NBS on 9 January 2006 with economy-wide revised nominal values and real growth rates of value-added for the three main economic sectors, including for the breakdown of the secondary sector into industry and construction, for 19932004. ${ }^{24}$ A follow-up announcement on 8 March 2006 elaborated further. A four-volume compendium solely on the 2004 economic census (Economic Census 2004) became available in June 2006. Subsequent Statistical Yearbook issues (of 2006 onwards) contain additional details 
that also cover the expenditure and income approaches. GDP 1952-2004 provides a complete, updated set of NIPA data for these years, incorporating the 2006 benchmark revision. Sixty Years also incorporates the 2006 benchmark revision (but provides only a limited amount of NIPA data).

The NBS does not provide an explanation for why the year 1993 is the earliest year for which NIPA data are being revised. The previous benchmark revision, following the 1993 tertiary sector census, led to a revision in the Statistical Yearbook 1995 of the 1991-1992 values as well as of the previously published 1993 values. I.e., the 1993 values have now been revised twice, in the benchmark revision following the 1993 tertiary sector census and in the benchmark revision following the economic census of 2004.

The Statistical Yearbook 2006 reproduces the earlier announced revised values, now expanded to include data on the two tertiary sector subsectors of 'transport and communication' and 'commerce and catering.' Tertiary sector value-added and GDP for 1978-1992 are also (slightly) revised. Exhaustive tertiary sector subsector value-added data following the economic census are available for 2004 only; revised detailed tertiary sector subsector values (on 14 subsectors) are not available for earlier years.

In the expenditure approach to the calculation of GDP, the Statistical Yearbook 2006 reports revised values for GDP and for expenditures, for the years since 1979. In the income approach to the calculation of GDP, the Statistical Yearbook 2006 reports post-economic census provincial data on GDP and its components for 2005; revised values of earlier years became available only with the publication of GDP 1952-2004.

The 2006 benchmark revision incorporates three types of data changes. First, presumably reliable data were collected. This matters most for those parts of the economy that are otherwise only covered in low-quality surveys or by guesstimates.

Second, the 2006 benchmark revision expanded the coverage of economic activities in the NIPA to include (i) economic activities previously ignored, such as those occurring in subordinate units of an enterprise and outside the main business of the enterprise, and (ii) economic activities captured through statistical compilations outside the economic census (and previously not included in GDP), such as homeowners renting out housing, home teaching, or childcare services (Xu Xianchun, 2006, p. 17). ${ }^{25}$

Third, the 2006 benchmark revision also incorporated three innovations in the calculation of sectoral value-added, implemented to comply with international practices (Xu Xianchun, 2006, pp. 17f.). Interest on household savings deposits was previously counted as financial sector value-added and is now attributed to the individual sectors that produced the particular valueadded. Depreciation on residential housing was previously based on construction costs, but is now based on current market values. Expenditures on computer software are not handled uniformly by all statistical units in China; the economic census collected data on income from computer software sales, which allows the NBS to include approximate expenditures on computer software in gross fixed capital formation. ${ }^{26}$

\subsubsection{Nominal 2006 benchmark revision values vs. earlier published values}

Section A of Table 6 presents the percentage difference of the revised nominal data (following the 2004 economic census) compared to the original nominal values (as previously published in, most recently, the Statistical Yearbook 2005) for the years 1978-2004. The revised nominal GDP figure for 2004 is 16.8 percent higher than the originally published one, with most of this 
increase due to an almost 50 percent upward revision to tertiary sector value-added. The primary sector was not part of the economic census. Nevertheless, primary sector value-added was revised upward for all years (1993-2004), by up to 0.9 percent. Upward revisions to industrial value-added remain below 4 percent, while construction value-added was reduced by up to 9.2 percent. Tertiary sector value-added increased by 5.9 percent in 1993 and by 48.7 percent in 2004. Figure 2 charts the revisions to GDP.

[Table 6 about here]

[Figure 2 about here]

\subsubsection{National nominal 2006 benchmark revision values vs. original provincial values}

Contrary to (former) NBS commissioner Li Deshui's justification for the discrepancies between national and summed provincial data (reported above), the 2004 economic census results imply that provinces did not over-report output values. The pre-economic census discrepancy between the summed provincial values and the first published national values was documented above in Table 3 (based on each year's Statistical Yearbook values), with, for example, a 19.3 percent higher summed provincial value than the national value in 2004. It is also documented in Section B of Table 6 with a comparison between summed provincial pre-economic census values and a set of (pre-economic census) national values that have undergone only the usual annual revisions (and are reported in the Statistical Yearbook 2005).

Post-economic census, the picture is reversed. Section $C$ of Table 6 compares the summed provincial pre-economic census values to the post-economic census national values. If the national data from the 2006 benchmark revision are correct, the provinces previously underreported tertiary sector value-added (whereas former NBS commissioner Li Deshui claimed that they over-reported), presented accurate data for the primary sector (agriculture), and over-reported for industry and especially for construction. The pre-economic census summed provincial GDP was larger than the revised national figure only in 2004, by 2.1 percent. The preeconomic census national data, on the other hand, were rather inaccurate, as Section A of Table 6 attests.

Post-economic census 2004 provincial GDP values continue to exceed the national values every year, now rather consistently, by close to ten percentage points (Table 3). At the sectoral level, the summed provincial values tend to be little different from the national values in the primary sector and only a very few percentage points higher in the tertiary sector, but are more than ten percentage points higher in the secondary sector and jumping to almost twenty percent in 2010 and 2011 (Table 3).

The NBS has stated its intention to move to its own calculation of provincial GDP values, which would then presumably side-track data that come out of the provincial statistics bureaus altogether. ${ }^{27}$ But at least through 2004, provincial statistics have retrospectively been proven to be more accurate than national values.

\subsubsection{Statistical breaks}

The 2006 benchmark revision changed the nominal value-added of all sectors in 1993-2004 (Section A of Table 6), even though the primary sector was not part of the economic census. The most plausible explanation is that the coverage of economic activities in the economic census 
was expanded. The NBS also used the opportunity of the 2006 benchmark revision to introduce various innovations, including the allocation of interest on household savings deposits to the sector that produced the particular value-added. Presumably one or more of these innovations or the expansion in coverage affected primary sector value-added.

The economic census stipulation requires the economic census to classify data in accordance with GB2002 (SC, 5 Sept. 2004). GB2002 incorporates a number of innovations in comparison to GB1994. For example, in GB2002 'logging and transport of timber and bamboo' and 'preliminary processing of textile fibers' move from industry into agriculture. In the agricultural sector, 'household sideline business' is dissolved into the corresponding other (including industrial) sectors. The three main economic sectors thus are only approximately compatible between GB1994 and GB2002.

The NIPA section of the Statistical Yearbook 2006, which first incorporates the benchmark revision of 1993-2004 values, does not specify which classification system the data of the individual years follow. A note to the first table in the section (p. 57, note b) for two subsectors of the tertiary sector explicitly lists a number of reclassifications that start in 2005 only; these de facto correspond to the transition from GB1994 to GB2002. It also states that agricultural services are included with agriculture only since 2005, as they ought to be following GB2002but also following GB1994 prior to (and through) 2004, except that the official NIPA statistics de facto never followed GB1994 in this one respect. ${ }^{28}$ If these two signals were indicative of all sectoral data, then they imply a statistical break in all sectoral value-added between 2004 and 2005 in the Statistical Yearbook 2006 due to the switch to GB2002. The Statistical Yearbook 2007 (and subsequent issues) resolve the issue by publishing new sectoral data for all years since 1978 according to the GB2002: the value-added of industry and construction (and thus of the secondary sector) for 1978-2004 remain unchanged, the values of the tertiary sector are revised downward by approximately 1 percent, and those of the primary sector are revised upward by exactly the same absolute amount, corresponding to 1-2 percent of agricultural value-added.

The 2006 benchmark revision of 1993-2004 data was presumably conducted using GB1994. According to $\mathrm{Xu}$ Xianchun (head of the national income accounts division of the NBS), in revising pre-2004 values, the NBS followed OECD advice and used the "trend-difference" method: the 1992-2004 trend is established twice, using the pre-economic census (original) 2004 value as well as the post-economic census (new) 2004 value, and the annual relative divergence from the original trend is then applied to the new trend line to obtain annual post-economic census values for 1993-2003 (Xu Xianchun, 2006, p. 17). Figure 2, for GDP, suggests that such a procedure was indeed used. It appears that the NBS, before applying the trend-difference method, first rearranged the post-economic census 2004 data (compiled in accordance with the GB2002) to match the GB1994 in use in earlier years.

\subsubsection{Benchmark revision real growth rates}

The 2006 benchmark revision changed the real growth rates of tertiary sector value-added, but not those of the primary and secondary sectors. This is problematic. First, the retention of the original primary and secondary sector real growth rates is not plausible. Second, in one respect, a technically correct procedure has undesired implications. Third, the 2006 benchmark revision incorporated a revision of tertiary sector nominal values for the years 1978-1992 (and thereby also of GDP for those years), even though the benchmark revision was only supposed to cover 
the years 1993-2004. The overall impact was an upward revision of real GDP growth by less than the revision to nominal GDP values implies.

First, the 2006 benchmark revision left the real growth rates of primary and secondary sector value-added unchanged. One could believe a constant real growth rate series if the 1993 nominal primary sector value had been revised by the same percentage as the 2004 primary sector value, but that is not what the statistics show. The post-economic census adjustments to primary sector nominal value-added increased the previously published value of 1993 by only 0.1 percent, but that of 2004 by 0.9 percent (with a continuous increase in the years in between, see Section A of Table 6). The value of the newly found agricultural activities between 1993 and 2004 increased significantly faster than the value of the original agricultural activities, and if the newly found activities were subject to a similar deflator as the original ones, the resulting real growth rate of total agricultural activities should go up. What the NBS has done, instead, by not changing the real growth rates, is to impose an upward revision on the implicit deflator.

Compared to the primary sector, the revisions to 2004 value-added in the secondary sector are much larger (+3.8 percent for industry, -9.2 percent for construction). But the pattern of change over time is similar to the primary sector in that the revisions to the 1993 values are also significantly smaller (+0.3 percent, -0.8 percent) than those to the 2004 values. The two secondary sector subsectors experienced changes in nominal output that differ significantly from the pattern inherent in the previously published data. One would consequently expect the real growth rates to change correspondingly, but those have remained unchanged. The implication of not changing real growth rates is that the NBS raised the implicit deflator for industry and lowered that for construction.

There are two possible interpretations of this pattern. The first is that the NBS used the opportunity of the 2006 benchmark revision to switch to a new deflator for agriculture, industry, and construction. The purpose of the census was to collect 2004 nominal secondary and tertiary sector data, in particular output data; the purpose was not to collect comprehensive price data for 1993-2004 across these three sectors. The new deflators, thus, would have to come from some other source. But where do such new deflators come from? ${ }^{29}$ And why are they exactly the size that keeps the real growth rates of all years unchanged and thus causes a 1:1 change in nominal values, when the economic census collected new nominal output data for industry and construction (and the tertiary sector), and new data were, according to Xu Xianchun of the NBS, indeed collected? ${ }^{30}$ This scenario is not plausible.

A second possible interpretation is that the implicit deflators are not changed. Then, either the revised 1993-2004 nominal values or the unchanged real growth rates (or both) must be incorrect. To take the case of industry, the 2004 economic census resulted in an increase in the 2004 nominal value-added of industry by 3.8 percent and no change in the 1992 value.

Suppose that all of the 2004 adjustments were due solely to reallocations among sectors. Then, the reduction in reallocations to zero in 1992 is not plausible. More likely than not, the reallocation ought to occur in roughly the same proportion in each year. Reducing the revisions to zero in 1992 would simply be a matter of convenience. The implication would be that the earlier in the reform period, the (unnecessarily) less accurate are sectoral nominal value-added data. In the case of agriculture, industry, and the tertiary sector, official nominal value-added of the earlier years would be an understatement.

But even if reclassifications occurred, they could hardly account for all of the revision to 2004 industrial nominal value-added. The NBS in the Statistical Yearbook 2005 published preeconomic census 2004 values for the DRIEs. The post-economic census 2004 number of DRIEs 
reported in Economic Census 2004 is 26 percent higher than the pre-economic census 2004 value, and their post-economic census $2004 \mathrm{GOV}$ is eight percent higher than the pre-economic census 2004 value (with similar changes for other variables). Values change across virtually all individual industrial sectors, and these changes happen regardless of whether or not the label of the industrial sector changed due to the switch in the classification system from GB1994 to GB2002. ${ }^{31}$

Alternatively, suppose that all of the 2004 adjustment were due to an expanded coverage of economic activities in the economic census. The revised data for 2004 then may simply reflect the inability of the NBS to capture the proliferation of economic activities in recent years. But in that case, real growth rates should have been revised, which they were not.

Perhaps the truth is somewhere in between: real growth rates of all years prior to 2004 (and going back beyond 1993) should have been revised, and nominal value-added of earlier years should have been revised by more than it was. The implicit deflators, in all likelihood, should not have been revised.

A second issue is that the NBS's retention of the unchanged pre-economic census secondary sector real growth rates is not plausible. The secondary sector real growth rate is a weighted average of the real growth rates of industry and construction. Retaining the pre-economic census secondary sector real growth rates implies that the NBS did not change the weights of industry and construction in the calculation of secondary sector real growth rates. This is despite the increase in nominal value-added of industry and the decrease in nominal value-added of construction and even though these changes were sufficiently large to at least in some years change the real growth rate of the secondary sector, calculated with one decimal point and using a Törnqvist index or previous-year weights.

The NBS can justify not revising secondary sector real growth rates with its practice of using a Laspeyres volume index with decade (since 2000: five-year) base years to calculate real growth rates. The NBS's procedure and the procedure's shortcomings are discussed in detail in a separate section below.

Third, in the tertiary sector, economic census results led to upward revisions to both the nominal values and the real growth rates of 1993-2004. There is, thus, no issue of unrevised real growth rates. But the benchmark revision included revised tertiary sector nominal values for 1978-1992 (rather than only for 1993-2004). ${ }^{32}$ The corresponding real growth rates remained unchanged, implying changes to the implicit tertiary sector value-added deflator for these years. Because the proportion of the change to tertiary sector value-added is rather similar in 1978 and 1992, with 2.5 percent and 3.1 percent upward revisions, retaining the old real growth rates appears to be a simplifying assumption with limited consequences.

Perhaps these revisions reflect an expansion of the coverage of economic activities for 19781992, limited to the tertiary sector. Or the revisions to tertiary sector values of 1978-1992 could be a measure potentially unrelated to the 2004 economic census; it was not mentioned in any of the announcements on the 2004 economic census. One possibility then is that an error in the earlier data was corrected. GDP 1952-95 (preface, p. 1) states that the national and provincial data reflect the benchmark revision that followed the 1993 tertiary sector census, except for the case of Guangdong. The phrasing is ambiguous, but suppose that the national data in GDP 195295 incorporates the pre-tertiary sector census values for Guangdong's tertiary sector. The value of national 1992 tertiary sector value-added in the Statistical Yearbook 2005 (p. 51) is identical to that in GDP 1952-95 (p. 27), i.e., the pre-economic census national values in the Statistical Yearbook likely are also based on Guangdong values that do not incorporate the 1993 tertiary 
sector census. The Statistical Yearbook 2006 (p. 57), revising the 1978-1992 tertiary sector value-added (in addition to the post-economic census benchmark revision of the years 19932004), raises tertiary sector value-added of 1992 by 28.54b yuan. This amount is equal to 37 percent of the published Guangdong 1992 tertiary sector value-added of 77.41b yuan (GDP 1952-95, p. 724), which does not incorporate the tertiary sector census revisions. This percentage is remarkably close to the average (i.e., national) upward adjustment of 1992 tertiary sector value-added by 33 percent (Statistical Yearbook 1994, p. 32, 2005, p. 51). ${ }^{33}$

Overall, in the years 1993-2004, with only the tertiary sector real growth rates allowed to increase, the effect on real GDP growth is smaller than the increase in nominal 2004 GDP of 16.8 percent. The original average annual real growth rate between 1992 and 2004 using first published values is 9.2 percent; using the most updated pre-economic census 2004 real growth rates (from the Statistical Yearbook 2005) it is 9.4 percent, and using post-economic census 2004 published real growth rates it is 9.9 percent. ${ }^{34}$ (See Table 5 for the annual real growth rates.) Going one step further, and applying the first published implicit sectoral deflators of the primary, secondary and tertiary sectors to the post-economic census revised nominal sectoral values, and aggregating into real GDP growth using the Törnqvist index, results in an average annual real growth rate for 1993-2004 of 10.9 percent, 1.7 percentage points higher than the annual average of the first published real growth rates, and 1.0 percentage points higher than the annual average of the revised (most updated) official real growth rates. ${ }^{35}$ In other words, post-economic census 2004, the official real GDP growth rate was revised upward by 0.7 percentage points per year, but it should probably have been revised upward by more than twice that amount.

For the period 1993-2011, the official average annual real growth rate as first published of 9.4 percent compares to an updated official average annual real growth rate of 10.1 percent. The Törnqvist index using the most updated official nominal values and the first published implicit deflators of the three economic sectors yields 10.8 percent.

Compared to the real growth rates as first published (Table 5, first columns), the combination of post-economic census $(2004,2008)$ nominal values (published in the Statistical Yearbook 2006 and 2010 or more recent issues) and the first published implicit deflator yields real growth rates that in 1993 and 1994 are several percentage points higher (the 1993 difference may in part represent the benchmark revision following the 1993 tertiary sector census), and in the years since are higher by between a fraction of a percentage point and up to approximately two percentage points, except in 1996, with a small decline, and in 2007, with a 4-5 percentage point increase.

\subsubsection{Benchmark revision of expenditure data}

In the expenditure approach to the calculation of GDP — which is not the official approach to calculating GDP in China - the NBS chose to revise all nominal values from 1979 through 2004. In comparison to the revised production approach value of GDP (discussed above), the revised expenditure approach value is 1.1 percent lower in 1978, 2.3 percent higher in 2004, and 0.6 percent higher in 2008.

The Statistical Yearbook does not report real growth rates in the expenditure approach except for per capita household consumption. GDP 1952-95 and GDP 1996-2002 report pre-economic census real growth rates of consumption and gross capital formation (each with their main subcategories) for 1952-2002, and GDP 1952-2004 the corresponding post-economic census real growth rates for $1952-2004 .^{36}$ 
Table 7 shows the revisions to the nominal data. Expenditure approach GDP in 2004 was revised upward by 12.6 percent. This comprises, first, a 15.4 percent upward revision to final consumption, which in turn reflects an 8.2 percent upward revision to household consumption and a 41.1 percent upward revision to government consumption. Under household consumption, rural consumption was revised downward by 26.6 percent and urban consumption upward by 31.9 percent. Second, gross capital formation was revised upward by 10.0 percent, which in turn reflects a 4.4 percent upward revision to gross fixed capital formation and a 673.2 percent upward revision to inventory investment.

[Table 7 about here]

A redefinition of the two categories "rural” and "urban" population goes a long way towards explaining the redistributions within the category household consumption. Figure 3 shows how the (unchanged) total population is newly split into rural vs. urban for all years since 1978 with the relabeling of a large share of the rural population as urban population in the most recent years; in 2004, the post-economic census rural population is 16 percent smaller than the pre-economic census rural population, and the urban population 38 percent larger. The newly adopted ruralurban population data implicit in the aggregate and per capita household consumption data closely match the rural-urban population data published in the population section of the Statistical Yearbook series. ${ }^{37}$

[Figure 3 about here]

Prior to the 2006 benchmark revision, household consumption was derived largely, but not solely, from "social retail sales." 38 Since the economic census, the NBS in determining household consumption relies on household survey rather than on retail sales data (NBS 2007, p. 92). Across countries, consumption values collected in household surveys typically fall short of actual consumption. In China, consumption values from household surveys are one-quarter below consumption values based on retail sales. The NBS's new reliance on household survey rather than retail sales data thus tends to lower household consumption values. Per capita nominal consumption values of the rural and urban population were indeed revised downward (Table 7), but in the aggregate these downward revisions were more than made up for by the shift of low-consuption rural to high-consumption urban population.

The revisions to government consumption are very large and one may wonder where the 41.1 percent upward revision could possibly come from. Does the government spend many times more on the military than originally thought? A double-check with the definitions reveals no obvious reason for the size of the revisions. Prior to the benchmark revision, government consumption comprised: (i) regular (jingchangxing) budgetary business expenditures for relevant public institutions (youguan shiye), which includes military expenditures, (ii) regular extrabudgetary business expenditures, (iii) depreciation of fixed assets of administrative units and non-profit facilities/units, and (iv) the difference between gross output value and business income of urban and rural neighborhood committees (NBS 1997, p. 154). Since the 2006 benchmark revision, government consumption is defined as regular business expenditures plus depreciation of fixed assets less business income of the different types of government departments (NBS 2007, p. 101). ${ }^{39}$

Beginning in 1997, summed provincial government consumption began to ever more exceed the national value of government consumption to reach a 48.1 percent discrepancy in 2004 (Table 3). This could suggest that the provincial data were more accurate to begin with and that the NBS did not have (or decided not to provide) accurate data on nationwide government consumption. ${ }^{40}$ But if it were a recent problem (since 1997), the NBS should then not have 
revised upward government consumption for all years since 1978, or the choice to revise data for all years was arbitrary, perhaps to obtain a smooth series of government consumption. Separately, government consumption could comprise a large residual element now that household consumption is determined based on survey data rather than on social retail sales data (with the former yielding lower values than the latter).

The seven-fold upward revision to inventory investment suggests that inventory investment is a rather meaningless residual in the NBS's calculations. ${ }^{41}$ This implies, for example, that the data on inventory change cannot serve as a measure of macroeconomic cycles. ${ }^{42}$

The 2006 benchmark revision also led to a new set of real growth rates for 1979-2004 for all cagetories of consumption and gross capital formation. Per capita (total/rural/urban) real growth rates of consumption were revised slightly in all years, rising from an average annual 7.03 percent to 7.35 percent for the total population (with an almost perfectly identical annual change in the real growth rate of either 0.3 or 0.4 percentage points for 1979-2004), falling from 6.24 percent to 5.71 percent for the rural population, and falling from 6.28 percent to 6.18 for the urban population (for the changes, see central columns of Section A, Table 8). ${ }^{43}$ The implicit average annual deflators, at one decimal of a percentage point, are unchanged for the total and for the rural population, and differ by one decimal point for the urban population (Section B, Table 8); individual annual implicit deflators are revised by up to 0.5 and 0.9 percentage points in the rural and urban case.

[Table 8 about here]

Real growth rates of aggregate consumption in 1978-2002 were revised up by a nearconstant factor every year, with minor discrepancies possibly due to rounding in the published real growth rates: total consumption by 0.7 percentage points, household consumption by 0.4 percentage points, and government consumption by 1.5 percentage points; only rural and urban household consumption experience somewhat more variation (Section A, Table 8). The implicit deflators are virtually unchanged on average, with the same type of annual variation as in the case of per capita data (Section B, Table 8). The implicit deflators of the aggregate household consumption data (total/rural/urban) are near-identical to the deflators of per capita household consumption (Table 9). ${ }^{44}$

[Table 9 about here]

One scenario to make sense of the revisions to per capita and aggregate household consumption is the following. The NBS retained the 1978 nominal aggregate household consumption values (total/rural/urban). These come with corresponding 1978 per capita values as well as 1978 rural-urban population numbers that are identical to the population numbers in the Statistical Yearbook. For 2004, the NBS started with the rural and urban household survey consumption values (and separate, non-survey data on additional consumption items). These per capita nominal values were aggregated into aggregate rural and aggregate urban nominal household consumption values using the population statistics. The rural plus urban aggregates then yield total household consumption. ${ }^{45}$

In order to obtain a set of nominal values and real growth rates for 1979-2003/2004, the NBS may first have compared the 2004 to the 1978 aggregate nominal total household consumption values. A new average annual real growth rate (growth trend) may have been calculated by retaining the original deflators. The previous deviations from the previous growth trend were then superimposed on the new growth trend, yielding a rather systematic average annual increase in the real growth rate of $0.3-0.4$ percentage points. ${ }^{46}$ By retaining the original deflators, these revised real growth rates imply nominal (total) household consumption values for 1979-2003. 
The population statistics then imply a breakdown into nominal rural and urban household consumption, including per capita values, and the application of the original implicit deflators then imply the corresponding real growth rates of rural and urban household consumption (aggregate, and per capita values).

Gross fixed capital formation real growth rates were significantly revised for only a few years (in particular, for 1981 and 1982, and for 1998 and 1999), with no major aggregate effect over time (Table 8). The implicit deflators of gross fixed capital formation are unchanged except in 1998 (raised by 1.9 percentage points) and in 1999 (lowered by 2.0 percentage points). ${ }^{47}$ Inventory investment experienced numerous large changes to real growth rates as well as to implicit deflators that follow no particular pattern and do not offset each other.

The accuracy of the expenditure approach has been questioned before: calculating the component household consumption in the expenditure approach to GDP in accordance with the NBS's explanations of NBS practices, one is unable to replicate the NBS's results (Carsten Holz, 2004a). The 2006 benchmark revision contains three innovations: a redefinition of rural vs. urban population, a new method of data compilation for rural and urban consumption, and major changes to government consumption. The redefinition of the rural and urban population is most plausible. The new data compilation methods for rural and urban consumption remain to be replicated. ${ }^{48}$ The changes to government consumption are inexplicable.

\subsubsection{Benchmark revision of income data}

In the income approach to the calculation of GDP, GDP equals labor remuneration, net taxes on production, depreciation, and operating surplus. These data have always been published at the provincial level only, and only in nominal form. GDP 1952-2004 reports (revised) data, incorporating the 2006 benchmark revision, for the years 1993-2004.

Income approach data come with a high degree of inaccuracy. Thus, data on labor remunderation in the countryside are difficult to obtain. Data on rural household income are compiled by three different institutions, namely by the county statistics department through surveys, by the county rural economy committee (xian nongcun jingji weiyuanhui) through complete reporting based on village-level accounts, and by the rural survey teams through surveys. The results of all three differ. ${ }^{49}$ Households are unlikely to reveal all their income, especially if it is taxable. Similarly, localities may wish to underreport net taxes on production, whether to hide revenues or excess taxation practices.

Depreciation values tend to be underestimated as depreciation rates are low and are applied to the historical cost rather than to the current value of a fixed asset. In enterprise accounts, the underestimation of depreciation implies an overestimation of operating surplus and thus does not affect value-added. However, in those instances where operating surplus data are not available, underestimated depreciation implies that value-added is also underestimated. This is, for example, the case with imputations of the rental value of owner-occupied housing.

Operating surplus is sometimes obtained as a residual. For example, for agriculture, operating surplus is obtained as the difference between production approach value-added and the sum of labor remuneration, net taxes on production, and depreciation. For individual-owned commerce, at least through 2003, operating surplus is included in labor remuneration (and operating surplus is thus zero).

Using pre-economic census data, the shares of each of the four components in income approach GDP are approximately constant from 1978 through 2003. No data are available for 
2004. In 2005, with the now post-economic census data, the share of labor remuneration dropped from its 2003 level of 0.50 to 0.41 , and the share of operating surplus jumped from 0.20 to 0.30 . In other words, the NBS previously overestimated labor remuneration by 25 percent and underestimated operating surplus by 50 percent.

Because the official value-added data for the tertiary sector are mostly derived from income data, the adjustments to the income approach data have to square with the upward revision to tertiary sector value-added using the production approach. Given that the tertiary sector is relatively labor-intensive, one would expect an increase in tertiary sector value-added to go hand in hand with an increase in the economy-wide share of labor remuneration in GDP, rather than with a decrease. ${ }^{50}$ The economic census must have unearthed very large amounts of unreported or underestimated profit.

Between 2003 and 2005, summed provincial nominal value-added or income (with a preeconomic census 2003 value and a post-economic census 2005 value) increased by 46 percent. $^{51}$ Summed provincial labor remuneration increased by 22 percent, depreciation by 37 percent, and net taxes on production by 44 percent. The biggest difference is in operating surplus; between 2003 and 2005, operating surplus increased by 114 percent. $^{52} \mathrm{~A}$ first hunch is that the income (or value-added) of all activities newly included in the compilation of GDP data since the economic census has simply been attributed to operating surplus. If one were to subtract the newly found nominal production approach value-added of 2004 from the 2005 operating surplus, the thus adjusted 2005 operating surplus would be 29.57 percent higher than that of 2003, which would seem plausible. $^{53}$

However, the revised provincial income approach values for 1993-2004 as published in GDP 1952-2004 suggest more nuanced revisions in form of a gradual adjustment plus a final jump (in 2004). Figure 4 shows that in the revised data the reduction in the share of labor remuneration and the increase in the share of operating surplus have in part been distributed across all years back to 1993. There is still a clear break in the year of the economic census, with disontinuities in 2004. (For the analysis above, using the data published in the Statistical Yearbook series, no 2004 values are available; 2005 shares are similar to the post-economic census 2004 shares reported in GDP 1952-2004.)

[Figure 4 about here]

Going back to individual provinces' data, the degree of revisions over time varies drastically. For example, for 1993, Beijing revised labor remuneration down by 16 percent and operating surplus up by 52 percent. Inner Mongolia, on the other hand, revised labor remuneration up by 13 percent and operating surplus down by 36 percent. Henan left its data for 1993 largely unchanged but then implemented gradual changes in the following years until, by 2002, labor remuneration was down 24 percent compared to the pre-economic census figure, and operating surplus up 110 percent (Table 10). Not reported in the table, Liaoning stuck to its earlier data for all years and never made a jump in 2004; Tibet implemented consistent downward revisions to depreciation (in 2000 by 67 percent) and consistent upward revisions to net taxes on production (in 2000 by 541 percent).

Perhaps the one (weak) pattern across provinces is that much of the upward revision to operating surplus occurs in the tertiary sector. This also shows up nationwide, across the sum of all provinces. Agricultural operating surplus tends to fall, in some provinces very significantly, even though the 2004 economic census did not cover agriculture. Nationwide, labor remuneration in 2002 is revised downward by only 4 percent (with the largest change of 8 percent in the secondary sector), in contrast to the wide variation in revisions to labor 
remuneration across provinces. The proportionally largest changes to the shares of labor remuneration and operating surplus in income only happen in 2004, the year for which preeconomic census data are no longer published (Figure 4).

[Table 10 about here]

The 2004 economic census appears to have triggered systematic revisions in some but not all provinces. These revisions perhaps follow central instructions, should central instructions have been issued (none are in the public realm). Large redistributions between depreciation and net taxes on production go unnoticed in the summed provincial data because the redistributions by individual provinces cancel each other out. The revisions to income approach data, although occurring as part of the set of 2006 benchmark revisions triggered by the 2004 economic census, appear to follow their own rationales that go beyond adjusting the overall income value to match the overall output value (value-added, GDP).

The gradual adjustment in the summed provincial data appears as much due to individual provinces adopting revisions at different points of time as to an increasing scale of revisions for individual provinces over time. Assuming that the post-economic census values of the 2004 income components are correct, one may wonder if previous years' component values ought not to have been changed by the same percentage as the 2004 values. Across countries, labor remuneration as a share of GDP tends to be constant over time; the trend in the revised summed provincial series between 1993/95 and 2007 appears too steep to be plausible (Figure 4).

Bai Chong-en and Qian Zhenjie (2009, 2010) document two definitional changes introduced by the NBS in 2004. Starting with the 2004 data, first, all income of the owners of "individualowned enterprises" (the "self-employed") is newly included in operating surplus (rather than in labor remuneration, as before) and, second, the operating surplus of collective- and state-owned agricultural enterprises is newly included in labor remuneration with no further attempt to split operating surplus and labor remuneration (due to the difficulty of obtaining accurate data).

The authors distinguish between the period 2003-2004 and the earlier years 1995-2003, with a 5.25 and 5.48 percentage point drop in the labor share. They attempt to estimate the 2004 labor share according to the pre-2004 definition and conclude that the 5.25 percentage point drop in the share of labor remuneration between 2003 and 2004 comprises a 6.29 percentage point drop due solely to the redefinitions (with -7.09 percentage points due to the income of the selfemployed being counted as operating surplus, and +0.81 percentage points due to the operating surplus of collective- and state-owned agricultural enterprises being counted as labor remuneration). The authors try to explain the 5.48 percent drop in the labor share between 1995 and 2003 with (i) structural change, accounting for a 3.36 percentage point drop (labor moving from sectors with high labor remuneration shares to sectors with low labor remuneration shares) and (ii) changes to the labor share in individual sectors, accounting for the remaining 2.12 percentage point drop. ${ }^{54}$ Their later publication refines their analysis and extends it to 2007.

According to Bai Chong-en and Qian Zhenjie, thus, the income data and the newly published 2004 data reflect redefinitions as well as economic factors. The authors for their analysis use the post-economic census 2004 revised data only and attribute all definitional changes to the year 2004 (in comparison to the year 2003), i.e., they do not consider the possibility that some provinces may have retrospectively revised their earlier data to adopt the new definitions. The declining trend in the labor share could in part be due to only a very few provinces applying the new definitions retrospectively all the way back to 1995, with some provinces only going a few years back, and some provinces only implementing the new definitions with the 2004 data. The overall impression from individual provinces' data is that the retrospective revisions are rather 
unsystematic and could well reflect an amalgamation of different points in time when the new definition is adopted, revisions based on new data obtained in the 2004 economic census, and a possibly underlying downward trend in the labor share.

\subsubsection{Implications of the 2006 benchmark revision}

The 2006 benchmark revision reveals a number of problems in NBS practices. The fact that the 2004 economic census validated original provincial GDP data and invalidated original national GDP data raises questions about the capacity of the NBS to compile accurate national data. Primary and secondary sector real growth rates for 1993-2004 should have been revised but were not. The official revised average annual real GDP growth rate for 1993-2004 may be on the order of one percentage point too low.

In the expenditure approach, the NBS used the opportunity of the 2006 benchmark revision to implement adjustments to the values of all consumption categories for all years 1979-2004. Changes to nominal household consumption are at least partly explained by major innovations in data compilation methods. Implicit deflators are almost unchanged (with a continued, large discrepancy to the CPI in 1989) and instead real growth rates were revised. Drastic changes to government consumption are unexplained.

In the income approach — for which only provincial long-run data are available - the revisions affect all sectors (including the primary sector, which was not part of the economic census). The shares of labor remuneration and operating surplus in income change significantly. The revisions go back to 1993 with different provinces starting the revisions in different years and implementing them at a different pace. Apart fom the overall trends, the development of the four income shares can differ considerably between any two provinces, and revisions can move in different directions. Consequently, either the pre-economic census or the post-economic census income data, or both, are likely to be to be quite inaccurate, but not systematically so.

Prior to the release of the 2006 benchmark revision, the NBS repeatedly dropped hints that national tertiary sector value-added had been underreported, which suggests that it knowingly reported false GDP data for at least the most recent years prior to 2006. The fact that the implicit deflators of the primary and secondary sectors rather than their real growth rates were revised raises questions about the accuracy or relevance of the economic census in the secondary sector. It appears as if the NBS simply did not want to increase the real growth rates in these two sectors, which would imply that the NBS's priority is not to compile accurate statistics at all times, but to not revise GDP real growth rates by too much. ${ }^{55}$

With a solid basis in the form of the 2004 economic census, one would expect future data to be more reliable. But reports from the grassroots suggest that the economic census was, at least in some localities, poorly organized, possibly severely under-funded, and in several respects not suited to capture the value of economic activities. ${ }^{56}$ If the economic census were indeed a complete waste of time and money (unlikely), then the NBS may well have good reason to retain its earlier real growth rates in the primary and secondary sector.

\subsection{7 revision of NIPA data}

Primary and tertiary sector value-added of 1978-2004 were revised in the Statistical Yearbook 2007. Primary sector value-added increased by between 0.90 percent (identically across 1978- 
1990 ) and 2.18 percent (in 2004). Tertiary sector value added decreased by just above one percentage point (maximum 1.34 percent in 1982) to around 0.6 percent (in the 1990s and 2000s). The absolute changes in value-added of the two sectors exactly cancel each other out. This suggests that specific economic activities were re-classified from the tertiary sector to the primary sector. In all likelihood, these are the agricultural services, which in contradiction of the classification system, had been included in the tertiary sector until 2004 (including in the first released post-economic census 2004 data of 2006). ${ }^{57}$

\subsection{0 benchmark revision of NIPA data following the 2008 economic census}

The 2008 economic census led to a benchmark revision of 2005-2008 data first implemented with the data published in the Statistical Yearbook 2010. Both production and expenditure approach values were revised (the latter starting in 2001). Income data experience a statistical break between 2008 and 2009.

\subsubsection{Value-added}

Compared to the 2006 benchmark revision, the 2010 benchmark revision to 2005-2008 data is far less extensive. It is also more plausible in that the NBS allowed for significant revisions to real growth rates rather than relying predominantly on changes to the implicit deflators.

Nominal GDP of 2008 was revised upward by 4.4 percent, and GDP of 2005-2007 by 0.9, 2.1, and 3.3 percent (Table 11). Much of the adjustment comes from significant increases to value-added in construction (by a maximum of 9.8 percent in 2008) —in contrast to the 2006 benchmark revision which led to a -9.2 percent (downward) revision to 2004 value-added in construction —as well as to renewed upward adjustments to tertiary sector value-added (9.0 percent in 2008). Pre-economic census summed provincial values exceeded pre-economic census national values, as one would expect given past experience, and they continued to do so even for post-economic census national values (though no longer in construction and in the tertiary sector). Revised (post-economic census) provincial values are not available except for gross regional product, which was also revised upward, so that post-economic census summed provincial gross regional product continues to exceed the national post-economic census values (in 2005-2008, by 7.7, 7.6, 5.2, and 6.1 percent).

Real growth rates of national value-added were revised upward in construction and in the tertiary sector in all years, and significantly so (between 1.7 and 3.5 percentage points), with corresponding upward adjustments to secondary sector as well as total value-added. For 2008 (only), growth rates of the primary sector and of industry were also, minimally, adjusted. The implicit deflators changed by sufficiently small amounts (always below one percentage point) that they might just possibly be attributable to changing weights (due to new nominal values) applied to subsectors within each sector, though that argument still remains a bit of a stretch.

[Table 11 about here] 


\subsubsection{Expenditures}

The 2010 benchmark revision led to a revision of 2001-2008 consumption values, 2005-2008 gross capital formation values, and 2003-2008 net export values (Table 12). A 6.8 percent upward revision to 1999 net exports appears an exceptional revision.

The revisions are rather limited throughout, with a maximum revision of 3.8 percent, except for inventory changes, for which revisions are significantly larger (but inventory changes are often calculated from a very low base and likely obtained as residual). The following the previous economic census drastically revised upward government consumption values are now taken back slightly for the years 2001-2005, while household consumption increases. Gross fixed capital formation of 2005-2007 is revised downward, that of 2008 upward. Since after 2004, no real growth rates for consumption and gross capital formation have been published.

[Table 12 about here]

\subsubsection{Income}

In a rare occurrence, (provincial) income data for 2008 have not been published. The income data again published since 2009 go back to the patterns exhibited in the pre-economic census 2004 data (Figure 4). While the 2006 benchmark revision led to a severe downward revision to labor compensation and a corresponding upward revision to operating surplus, with retrospective revisions back to 1993, the 2010 benchmark revision raised the share of labor compensation in income GDP back to the higher level and the trend exhibited in the data published before the 2006 benchmark revision (with values through 2003), and the share of operating surplus correspondingly back to its earlier, lower level with its earlier trend. These reorganizations are so strikingly opposite to the 2006 benchmark revision that they are probably not so much due to data corrections than to (unspecified) re-definitions. In the early 2000s, following the stateowned enterprise (SOE) reform program of 1998-2000, policy makers' concern may have focused on profitability, while by the late 2000s focus shifted to the welfare of workers; an increase in operating surplus implies an increase in profitability (given the denominator of profitability), while an increase in labor remuneration implies an increase in workers' living standards.

If Bai Chong-en and Qian Zhenjie’s (2009, 2010) findings of two redefinitions of labor remuneration in 2004 are correct, then these redefinitions may simply have been reversed in 2010. The fact that the labor share returns to the trends inherent in the pre-economic census 2004 data suggests either that state-owned enterprise restructuring and increased monopolization has come to an end by the mid-2000s, or that some of the post-economic census 2004 retrospective revisions to earlier published provincial income data in fact reflected adoption of the new (now probably reversed) definitions by some provinces going back some years (rather than in 2004 only).

\subsection{Real growth rates of GDP vs. of GDP components}

In the Statistical Yearbook 2008, the NBS for the first time published real GDP figures for the reform period, i.e., annual GDP values expressed in base year prices, with 1970, 1980, 1990, 2000, and 2005 as base years for the subsequent years. For unexplained reasons, the 1980 and 
1990 GDP values differ slightly from the GDP values of these years as reported in the Statistical Yearbook table with nominal values, as do the tertiary sector values in these two years and the primary sector value in the first year. ${ }^{58}$

The summed sectoral real value-added (sectoral volume) equals real GDP. I.e., the NBS creates a real value-added series for each sector and then sums the sectoral values to obtain a real GDP series, from which GDP real growth rates can be calculated in a second step. This is equivalent to using previous-year weights, where the weights consist of sectoral real value-added in base year prices (see second-to-last column in Table 13). At the level of accuracy at which the NBS publishes real growth rates (with one decimal, in form of X.Y percent), the published real growth rates of GDP and of sectoral value-added match the real GDP series and sectoral real value-added. Likewise, industry and construction add up to secondary sector real value-added, and their implicit real growth rates match the published official ones.

[Table 13 about here]

The NBS thus uses a consistent procedure, a Laspeyres volume index in constant base year prices, to aggregate sectoral real growth rates into real GDP growth rates (and similarly for industry and construction). The Laspeyres volume index has the advantage of allowing full additivity of sectors and thus the aggregation of sectoral real values into real GDP. It is a procedure also traditionally used by statistical authorities in other countries.

However, this particular choice of procedure comes at the cost of weighting sectoral growth using a past price structure and, in the case of China, a past price structure that is up to ten years out-of-date. Given China's rapid economic development and growth, as well as structural change, this past price structure is potentially incompatible with the current price structure and thus may lead to biased real GDP growth rates.

A chain-linked index would seem preferable: the price weights reflect the actual price structure more accurately. Most Western countries have adopted a chain-linked index, typically a Laspeyres chain (using the previous year's price structure), and sometimes Fisher chains (geometric mean of a Laspeyres volume index and a Paasche volume index). China does not publish any form of chain-linked index and the available data do not allow the construction of a Laspeyres chain or a Fisher chain.

Table 13 contrasts the official real GDP growth rates, obtained by the NBS as described above, and real GDP growth rates reconstituted from sectoral real growth rates using four different methods. If the price structure between sectors changes over time, then the first three methods are likely to yield more accurate results for real GDP growth than the Laspeyres volume index at constant base year prices used by the NBS. ${ }^{59}$ Using the sum of annual absolute deviations as a measure of the discrepancy between the official real GDP growth rate and reconstituted real GDP growth rates, a Törnqvist index and previous-year weights are relatively close to the official real GDP growth rate, followed by current-year weights. ${ }^{60}$ Using decade nominal sectoral weights (year 1980 weights for the years 1981-1990, and similarly with 1990 and 2000 weights) yields results that are furthest from the official real GDP growth rates.

The Laspayres volume index (used by the NBS) tends to overstate real growth. The introduction of new products whose prices fall over time (for a given model), such as computers or cell phones, leads to an overstatement of growth because the rapidly increasing output quantity (that comes with price reductions) is weighted with the high base year price. At the level of the three main economic sectors, the data for China indeed show that the official real GDP growth rates (based on the NBS's Laspayres volume index) exceed real GDP growth rates which 
are aggregated from the real growth rates of sectoral value-added using more up-to-date price information (Table 13).

The Törnqvist index appears a particular attractive alternative to the officially used Laspayres volume index in that it uses previous-year and current-year price (and quantity) information. Ideally, what one would like to have is a much more detailed breakdown of data by subsector if not product, with subsector- or product-specific prices. The official real growth rates of sectoral value-added themselves are, after all, Laspayres volume indices with a decade (since 2000: fiveyear) base prices, and thus reflect potentially out-of-date price structures. Application of a Törnqvist index thus resolves only in part-between sectors - the issue of outdated price (weight) information. Using this limited Törnqvist index, China's official real growth rate on average exceeds the "actual” (limited Törnqvist) real growth rate by 0.05 (1978-2004) or 0.02 (19782011) percentage points per year-a very small discrepancy.

In the expenditure approach, the NBS reports the real growth rates of final consumption with its different components and of gross capital formation with its two components. It does not report real growth rates of net exports or of GDP. ${ }^{61}$ The NBS does not specify how it obtained the real growth rates of consumption and gross capital formation. One conjecture is that the NBS, as in the production approach, uses a Laspeyres volume index at constant base year prices. One can apply the published real growth rates for consumption and gross capital formation to the nominal 1970, 1980, 1990, and 2000 values in order to re-configure a volume series for consumption and gross capital formation (and their subcategories). The thus obtained volume series for rural and urban household consumption indeed add up to total household consumption, the volume series for total household consumption and government consumption add up to final consumption, and the volume series for gross fixed capital formation and inventory investment add up to gross capital formation, all with very minor margins of error as plausible given that the published official real growth rates come with only one percentage decimal. ${ }^{62}$

Adding a volume series of net exports, approximated by deflating nominal net exports using the implicit deflator of production approach GDP, allows the construction of a volume series for expenditures. The resulting real growth rates of aggregate expenditures (last column of Table 13) in most years differ noticeably from the official production approach real GDP growth rates, with annual growth up to 3.9 percentage points higher and up to 3.0 percentage points lower. But on average, official annual (production approach) real GDP growth rates are only 0.1 percentage points different from (higher than) expenditure real growth rates. ${ }^{63}$

In conclusion, while China's official GDP real growth rates are based on a traditional calculation method that is likely to overstate real growth, applying a more meaningful method to the available sectora data in deriving GDP real growth yields no significantly different results. It would be desirable to work with much more disaggregated constant-price subsectoral data, but such data are not available. Similarly, expenditure real growth rates derived from constant-price individual expenditure components are not significantly different from the official GDP real growth rates.

\subsection{GDP deflator and NBS compilation of sectoral real output}

The NBS does not publish GDP deflators. An implicit deflator can be obtained by dividing nominal GDP growth (in form of 1.X) by real GDP growth (1.Y), where nominal GDP is the sum of sectoral nominal value-added and real GDP is the sum of sectoral real value-added. 
One would like to think of a deflator as a price index in terms of a Laspeyres or a Paasche price index, i.e., as

$$
\frac{\sum p_{t} q_{t-1}}{\sum p_{t-1} q_{t-1}} \quad \text { or } \quad \frac{\sum p_{t} q_{t}}{\sum p_{t-1} q_{t}}
$$

where p denotes price, $\mathrm{q}$ denotes quantity, $\mathrm{t}$ denotes time, and the sum is across products. But with the NBS's Laspeyres volume indices at constant base year prices for real growth, the implict deflators reduce to a Laspeyres price index only if the product coverage is limited to one product. Take, for example, period 3. Dividing nominal by real growth to obtain the implicit deflator translates into

$$
\frac{\sum p_{3} q_{3}}{\sum p_{2} q_{2}} / \frac{\sum p_{0} q_{3}}{\sum p_{0} q_{2}}
$$

which in turn reduces to $\mathrm{p}_{3} / \mathrm{p}_{2}$ only if there is just one product. ${ }^{64}$

The NBS presumably does not publish deflators for its NIPA because for most sectors it does not operate with deflators. It obtains values for nominal value-added and for value-added at base year prices. The remainder of this section examines how the NBS obtains real value-added across the different sectors.

In agriculture, through at least 2003, the NBS obtained real value-added (with value-added taxes added separately in those years when not included in GOV) as the difference between real GOV and the real value of intermediate inputs. Real GOV was obtained by first multiplying individual output quantities by NBS-provided constant prices and then applying the resulting aggregate constant-price real growth index to the base year value of agricultural GOV. The real value of intermediate inputs was obtained by applying 14 price indices to the current-price values of 14 different categories of intermediate inputs. ${ }^{65}$

The procedure is likely to have changed in 2004. NBS (2007) specifies the practices used in the compilation of the 2004 economic census data. While the primary objective of the publication appears to be to provide details on the compilation of nominal data, it also contains instructions for the calculation of real growth rates. The 2006 benchmark revision of nominal data was conducted by applying the trend deviation method for the years between 1992 and 2004, rather than by compiling new data for each year. For real growth rates, it is unlikely that the NBS switched to new deflation methods of retrospective data. Since 2004, the deflation practices described in NBS (2007) for 2004 presumably equally apply to the subsequent years' data. For agriculture, NBS (2007, pp. 12f.) again specifies real value-added as the difference of real GOV and real intermediate inputs. But these latter two are now both obtained by dividing the nominal values by corresponding price indices. ${ }^{66}$

In construction, real value-added is obtained using a price index. In the tertiary sector, most subsectors use price indices, but real value-added of some activities in 'transport and communication' is obtained using constant prices, while for other activities the base year valueadded is multiplied by an output quantity growth factor. ${ }^{67}$

Given the criticism of official real growth rates of industry in the literature, the case of industry is in the following examined in greater detail. ${ }^{68}$ Prior to 2004, the NBS obtained real 
growth rates for industry by applying a deflator to current-price industrial value-added. The details are as follows.

Current-price value-added of all industry is the sum of two separate datapoints. In the case of the DRIEs, value-added is obtained as the difference between GOV and the value of intermediate inputs, plus, since 1995 (when GOV no longer included value-added taxes), value-added taxes applicable to the products produced. In the case of all other industrial enterprises, a sample survey collects data on GOV and the income components of value-added; the ratio of valueadded to GOV in this sample is then applied to the GOV of all non-DRIEs. ${ }^{69}$

The deflator for industrial value-added is a GOV deflator with adjustments. The GOV deflator is obtained in a two-step procedure. First, enterprises-and presumably these are the DRIEs only-price their output at (base year) product-specific constant prices provided by the NBS and revised approximately every decade. ${ }^{70}$ Aggregating across products yields a constantprice GOV time series and thereby a constant-price (real) growth index. Since some NBSdetermined (base year) constant prices may differ from the base year market prices, the NBS applies this constant-price growth index to the base year's current (i.e., market) price GOV (of, again, presumably, the DRIEs) to obtain a real GOV time series in the (market) base year's prices for the (presumably) DRIEs. Contrasting this time series to the series of current-price GOV of these enterprises yields the deflator. For the purpose of deflating value-added, adjustments are made to this deflator depending on the development of the raw materials price index. (Otherwise, the underlying assumption for this deflator to be relevant for value-added would be that intermediate inputs experience the same price changes as GOV.) The adjusted deflator is finally applied to the value-added of all industry in order to obtain the real growth rate of industrial value-added.

Given the brevity and vagueness of the explanations on these procedures in $\mathrm{Xu}$ Xianchun (2000, pp. 76f) as well as in NBS (1997), the possibility cannot be ruled out that the NBS's calculations of the constant-price GOV growth index are based on all industrial enterprises. However, this appears technically impossible because the NBS does not have available product quantity data for all industry. ${ }^{71}$ According to the NBS (NBS Industry and Transport Division, 1999, p. 4), the regular annual statistical reporting system for industry comprises a number of report forms (listed in detail in this source). The only annual report form to include product quantities is a report form filed by the DRIEs. The reprinted report form for small enterprises (p. 38) collects data only on four variables, namely current-price GOV (or business revenue, yingye shouru, if GOV data are not available), tax payments, paid-in capital, and year-end employment.

The GDP Manual of 2001, an internal document on the compilation of GDP data, states that the GOV deflator, which is applied to current-price value-added in order to obtain real growth rates of value-added, is in fact the ex-factory price index compiled by the urban survey team (p. 67). This contrasts with the constant price method outlined above. Similarly, former NBS commissioner Li Deshui's statement regarding the reasons for the discrepancies between summed provincial and national GDP, reported above, suggests that the price index method (without specifying the use of the ex-factory price index) became the standard method at the national level in 2004. NBS (2007, p. 21), with its focus on the 2004 economic census, states that real value-added of individual industrial sectors is obtained by dividing nominal value-added by the corresponding component (sub-index) of the ex-factory price index of industrial goods. The Statistical Yearbook no longer reports GOV in base year prices for the DRIEs (or any other enterprise group) starting with the year 2004; all output values in the industry section of the Statistical Yearbook now are nominal values. ${ }^{72}$ 
As a double-check against the data, Table 14 reports three implicit deflators of industrial value-added in the NIPA and a wide range of related industrial deflators and price indices to compare the NIPA deflators to. All deflators are implicit deflators obtained from nominal values and real growth rates. The three implicit deflators of industrial value-added in the NIPA are compiled from pre-economic census data, post-economic census data, and the nominal values and real growth rates of a particular year as first published (before undergoing the annual revisions). In as far as prices (underlying the implicit deflators of industrial value-added) as well as the various alternative industrial output measures (in nominal form and real growth rates) are usually not revised in a later year, value-added deflators as first published, available for the years since 1991, appear the most relevant ones for comparison. ${ }^{73}$ Figure 5 charts the three series. The implicit deflator as first published is significantly higher than the other two in 1991 and significantly lower in 1994; otherwise the series move very closely in step.

[Table 14 about here]

[Figure 5 about here]

The nine deflators of various industrial output measures reported in Table 14 differ to varying extent from the three implicit deflators of industrial value-added, with measures of the differences provided at the bottom of Table 14. The NBS apparently does not follow strictly one specific procedure in deriving the implicit deflator (or the prices) of industrial value-added from the underlying industrial output data across all years.

One scenario that appears plausible, given the explanations on data compilation as well as the data themselves, is that the NBS used the GOV deflator of the enterprises at the township level and above through sometime around 1997 (when this series ends), although the stated adjustment to the GOV deflator based on the raw materials price index appears to not have happened (given that such an adjustment would in many years have moved the GOV deflator further away from the deflator of industrial value-added). After 1997, the NBS may have switched to the ex-factory price index of industrial products. ${ }^{74}$ The deflator of summed provincial GOV provides an only slightly inferior match across all years until 2002, when this series ends.

Figure 6 (with a different vertical scale than Figure 5) graphically illustrates the match between the two GOV deflators (GOV of the enterprises at the township level and above, summed provincial GOV) and the implicit deflator of industrial value-added. Relatively large discrepancies occur in 1989, when the implicit deflator of industrial value-added is a gross underestimate in comparison, ${ }^{75}$ and in 1994, when the GOV deflators are significantly lower than the implicit deflator of industrial value-added except in the latter's version as first published implicit deflator (compare Figure 5). The ex-factory price index of industrial products, in turn, diverges from the implicit deflator of industrial value-added through 1995, but matches well since then. (With data on only one of the included series, the ex-factory price index, extending beyond 2004, Figure 6 ends with the 2004 values. See Table 14 for the values of all years.)

None of the other series matches the three implicit deflators of industrial value-added as well over extended periods. These series include the deflator of industrial GOV; the deflator of GOV of the DRIEs or of their subgroup of SOEs; ${ }^{76}$ the purchasing price index of raw materials, fuel and power; and a value-added deflator obtained by deflating GOV and intermediate inputs separately. $^{77}$

In the expenditure approach, detailed explanations of the calculation of real expenditures are provided in NBS (1997). They are similar to those offered for the the year 2004, and presumably for the years since 2004, in NBS (2007), and are too lengthy to repeat in full here. In brief, according to NBS (2007), household consumption is deflated by product (service) category using 
sub-indices of the CPI, except that the investment in fixed assets price index is applied to the imputed value of owner-occupied housing services and enters a weighted deflator (together with the CPI) for financial services. ${ }^{78}$ Government consumption in form of fixed asset depreciation is deflated with the investment in fixed assets price index, and all other government consumption with the CPI. Gross fixed capital formation is deflated with the investment in fixed assets price index, while inventory investment is deflated by sector with a variety of methods. Exports and imports of goods and services are deflated with price indices that incorporate information from the Customs Office, other countries, and the service component of the CPI; these price indices are not published, and neither are real growth rates or real value series (which would allow the calculation of implicit deflators).

As shown in Table 15, the implicit deflators of household consumption closely follow the CPI, except in 1989, when the CPI is substantially higher, in the rural case by almost 10 percentage points. The implicit deflator of government consumption through the 1990s appears too low when compared to the CPI; in the early 1990s it could be the weighted average of the CPI and the investment in fixed assets price index, but then starting in the second half of the 1990s its values are usually outside the joint range of the CPI and the investment in fixed assets price index. The implicit deflator of gross fixed capital formation very closely matches the fixed asset price index.

[Table 15 about here]

\subsection{Directly reporting industrial enterprise data}

The available annual data on industrial sectors (i.e., individual industries) do not cover all industrial enterprises, but only the DRIEs, and some ownership groups within the DRIEs. Valueadded data on the DRIEs are available from 1992 through 2007. No value-added data on the DRIEs (or any other group of industrial enterprises) for the years prior to 1992 have been published retrospectively, and the data on the DRIEs as first published are always final.

For the years prior to 1993, the Industrial Yearbook 1993, pp. 90ff., reports sectoral data on the DRIEs in 30 sectors for the years 1980 and 1984-1992 (following GB1984). ${ }^{79}$ The output variables are GOV and net material product (following the MPS), both in current prices, as well as, in 1992 only, current-price value-added. Net material product equals value-added less depreciation, plus service charges paid to non-production units. Value-added for the years prior to 1992 could be approximated by adding depreciation values to net material product and deducting the service charges, but data on depreciation and service charges are not provided in this source. Service charges are presumably very small and could possibly be ignored. Depreciation values could be approximated by applying an assumed sectoral depreciation rate to the year-end sectoral original value of fixed assets; data on the original value of fixed assets are included in the source.

Value-added and GOV data are available for 1993-1997 (39 industrial sectors in GB1994), 1998-2002 (37 industrial sectors in GB1994), and for 2003-2011 (39 industrial sectors in GB2002) except that value-added data end in 2007. Data on GOV in base year prices are available for 1993-2003, except for 1998.

Sectoral output deflators are not available. For the years prior to 1993, the implicit GOV deflator of the industrial enterprises at the township level and above could be applied uniformly to all sectors, and in the more recent years, that of the DRIEs (for the deflators, see Table 14). Otherwise, the (14) subcategories of the ex-factory price index, reported, for example, in the 
price section of the Statistical Yearbook 1998, could be approximately matched with the industrial sectors, but Figure 6 suggests that the ex-factory price index of these years overestimates the deflator of industrial value-added. For the years 1993-2003 (except for 1998 and 1999), a sectoral GOV deflator can be calculated from the data on GOV in current prices and GOV in base year prices.

Starting with the Statistical Yearbook 2006, the price section contains ex-factory price indices - in the 2008 issue relabeled, in English only, "producer price index for manufactured goods"-for each individual industry. The classification system for the price indices by industrial sector is GB2002 and thus matches the classification used in the industry section of the Statistical Yearbook (which reports the output data) since 2003. ${ }^{80}$ These price indices are directly applicable to the output data reported in the industry section. The price data are available for the years since 2002.

In analysis of DRIE data, one also needs to bear in mind the change in the definition of the DRIEs in 1998, the de facto expanded coverage of DRIEs following the 2004 economic census, the slight re-definition in 2007, and the new size criterion for inclusion introduced with the 2011 data. The redefinition of 1998 is further accompanied by a change in the ownership classification among the DRIEs (for example, the SOE category prior to 1998 and since 1998 is not identically defined). Analysis that uses GOV data of DRIEs needs to consider the change in the definition of GOV in $1995 .{ }^{81}$

\section{CHOICE OF OUTPUT DATA FOR ECONOMIC ANALYSIS}

All value-added, expenditure, and income series in the NIPA were revised in the 2006 and 2010 benchmark revisions following the 2004 and 2008 economic censuses. While the most recently published data are preferable, the earlier published data may still have some uses, whether that is for the calculation of implicit deflators that are likely to be more reliable than if revised data are used, or whether some of the earlier data come in more detail than the revised data.

\subsection{GDP and value-added of the three main economic sectors}

\subsubsection{Published prior to the 2006 benchmark revision}

The production approach is China's official approach to calculating GDP. Pre-economic census data on GDP and value-added of the main economic sectors are available for the years 19522004 and are reproduced in Appendix 1. Real growth rates are reported in Appendix 2. For real GDP growth, one may want to replace the official data with a Törnqvist index of the official sectoral data, also reported in Appendix 2.

In the period 1990-2004, the value-added of the three main economic sectors as reported in the Statistical Yearbook series (and with identical values in GDP 1952-95 for the overlapping years) in all likelihood follows GB1994; the only exception is that agricultural services are included in the tertiary sector rather than, as stipulated by GB1994 (and GB1984 and GB2002), in the primary sector. The same tables in the Statistical Yearbook series also report values on the exhaustive two subsectors of industry and construction within the secondary sector, and on the 
two subsectors of 'transport and communication' and 'commerce and catering' within the tertiary sector; these series similarly follow GB1994. ${ }^{82}$

For the years prior to 1990, the choice of classification scheme is unclear. The preface to GDP 1952-95 contains a note stating explicitly that the data follow GB1984, with some exceptions. Two exceptions are potentially important for the main sectoral data. First, agricultural services are explicitly included in science etc., in the tertiary sector, rather than, as GB1984 requires, in agriculture. Second, if the default is indeed GB1984, then, implicitly, water conservancy is included in the primary sector rather than, as in GB1994, in the tertiary sector. At the level of the three main economic sectors, the first exception is consistent with the de facto practice in the years since 1990 (until the introduction of GB2002) of including agricultural services in the tertiary sector. The second exception is inconsistent with GB1994, where water conservancy is included in the tertiary sector. As explained below (Section 4.2), since 1990 it indeed is, but for the pre-1990 data no double-check is possible. I.e., it is possible that the preeconomic census data experience a (small) statistical break in 1990 with water conservancy moving from the primary to the tertiary sector; if there were no statistical break, then water conservancy is included in the tertiary sector in all years and the data follow GB1994 with the exception of the inclusion of agricultural services in the tertiary rather than the primary sector.

\subsubsection{Published after the 2006 benchmark revision}

Following the economic census of 2004, production approach GDP and sectoral value-added underwent two types of revisions. First, in the Statistical Yearbook 2006, the data of 1978/19932004 were revised (Appendix 1, Appendix 2). The sectoral classification follows GB1994 through 2004 (with the continued exceptional handling of agricultural services); the reported 2005 data follow GB2002. Second, since the Statistical Yearbook 2007, all data from 1978 onwards are classified according to GB2002 which, at the level of the three main economic sectors, means a transfer of agricultural services from the tertiary to the primary sector. ${ }^{83} \mathrm{GDP}$ 1952-2004, published in mid-2007, provides national data on GDP and the value-added of the three main economic sectors (with a breakdown of the secondary sector into industry and construction) for the years 1952-2004 in accordance with GB2002. I.e., a complete time series, economy-wide and for the three main economic sectors (and industry and construction), is now available for the years 1952 through today in accordance with GB2002. Appendix 3 reports these data in nominal form, as well as the real growth rates.

While the benchmark revision should yield superior data, the new data come with two caveats. First, real growth rates continue to be based on real output values priced in decade (since 2000: five-year) base year prices. Rapid economic development and structural change means that these real growth rates could be quite inaccurate several years after the base year.

Second, for the primary sector, industry and construction, the revision of only nominal values in the 2006 benchmark revision is not plausible. Even if the revision of nominal values in agriculture, industry, and construction were solely due to changes in the classification (not credible), one would still expect, given the systematic variation in the proportions of the revisions over time, that these changes in the sectoral allocation also lead to changes in real growth rates. The NBS practice of revising nominal but not real data means that the implicit deflators are being changed; but if real growth rates should have changed, then these revisions to implicit deflators capture not only the changed implicit deflators but also, in addition, the changes in the real growth rates. 
As an alternative, one could switch to the deflators implicit in the previously published data (Appendix 1 and Appendix 2). Or one could use the implicit deflator as first published; this would be the way to go if one believes that the NBS has available final prices when it first publishes the nominal values and real growth rates of a particular year in a Statistical Yearbook - which is highly likely, especially when output is priced at decade base year prices. Implicit deflators as first published are available only for the years since 1987/1992 and are reported in Appendix 4.

One shortcoming of switching to earlier published implicit deflators in the years 1993-2004 is that the benchmark revision led to changes in the relative weights of subsectors in the derivation of sectoral real growth rates (or deflators) due to differing degrees of newly covered economic activities in different subsectors and due to reclassifications among subsectors and the revision of the list of subsectors; a comprehensive set of revised subsector data is not available. Switching to implicit deflators as first published for the three main economic sectors, however, may still be desirable if one thinks these to be the most reliable deflators. The error introduced by the potential sectoral mismatch is probably of minor size (compared to attributing all, or much of the newly found value-added to the implicit deflators, as is the official practice). The same applies to GDP: the first published implicit deflators of the years through 2004 follow some adjusted version of GB1984 or GB1994, i.e., are not fully applicable to GB2002 data, but may be preferable to the "adjusted" implicit deflators following the 2006 benchmark revision.

Appendix 4, beyond the first published implicit deflators, also reports the real growth rates that are obtained if these first published implicit deflators are applied to the pre-economic census nominal values (following GB1994), to the post-economic census nominal values following GB1994, and to the post-economic census nominal values following GB2002. The differences to the official real GDP growth rates can be substantial. Comparing the official real GDP growth rates to those obtained by applying the first published implicit deflators to the most recently published nominal values (following GB2002), the official real GDP growth rates are lower by up to several percentage points in 1992-1994, 1999-2001, and 2007, and otherwise typically smaller by less than one percentage point.

\subsection{Value-added of the tertiary sector subsectors}

\subsubsection{Published prior to the 2006 benchmark revision}

For the years prior to 1990, GDP 1952-95 provides data on eight exhaustive tertiary sector subsectors for 1952-1995; these are reported in Appendix 5. Comprehensive tertiary sector subsector data on nominal value-added and real growth are available for 1990-2003 and reproduced in Appendix 6. For this comprehensive classification into 12 subsectors, the data are published with a one-year time lag, i.e., the published values already incorporate the annual revisions; this means the implicit deflator as "first published" is the "revised" one. The classification system is GB1994 with one exception: the tertiary sector includes data on a subsector agricultural services which, according to GB1994 (and GB1984 and GB2002), should be included in the primary sector. ${ }^{84}$ This is the practice in all published pre-economic census data.

Questions arise about the coverage of the first set of data, the 1952-1995 data on eight exhaustive tertiary sector subsectors published in GDP 1952-95. The preface to GDP 1952-95 contains a note stating explicitly that the data follow GB1984, with some exceptions. These are 
the following. (i) Agricultural services (services for farming, forestry, animal husbandry, fishery, and water conservancy) are included in science etc., i.e., in the tertiary sector, rather than, as in GB1984 (or GB1994 or GB2002), in the primary sector. ${ }^{85}$ (ii) Geological investigation and prospecting is also included in science etc. (rather than constituting a separate tertiary sector category as in GB1984, or a separate tertiary sector category together with 'water management' as in GB1994). (iii) 'Real estate administration, public facilities, resident services, and consulting services' (one subsector in GB1984) is split into 'real estate,' 'public facilities,' and (social) 'services,' a classification that is not present in this form in GB1994 (or in GB1984, or in the pre-1984 classification). The second and third exceptions are simple reclassifications within the tertiary sector. The first exception matches the practice in the 1990-2003 tertiary sector statistics and thus does not endanger comparability of the two sets of data.

One problem which the preface of GDP 1952-95 does not address is the extensive relabeling and reclassification among tertiary sector subsectors. ${ }^{86}$ This is particularly true for 'transport and communication' and for 'commerce and catering' (see Appendix 4). The explanations in the preface to GDP 1952-95 make no special mention that the 1952-1995 data for these two subsectors do not follow the default classification of GB1984. The preface to GDP 1952-95, furthermore, for these two subsectors, lists as complete titles (which are abbreviated in the statistical tables of this source) those that are used in GB1984, which immediately signals the different content in comparison to GB1994. ${ }^{87}$ However, the values of these two subsectors in 1990-1995, as reported in Appendix 5 (with all data from GDP 1952-95), are identical to those in Appendix 6 (with data for 1990-2003 from the Statistical Yearbook), and the latter follow GB1994. This means either that the preface is incorrect in its labeling and in its claim that GB1984 is the default classification system, or, alternatively, that the 1952-1995 data for these two sectors follow GB1994 in 1990-1995, but GB1984 in earlier years.

The values of the two tertiary sector subsectors of 'transport and communication' and of 'commerce and catering' in 1989 and 1990 indeed hint at a statistical break between 1989 and 1990, with the values through 1989 then presumably following GB1984, and those since 1990 GB1994 (Appendix 5). The value of 'transport and communication,' which in GB1994 newly (in comparison to GB1984) included storage, increased dramatically by nominally 46 percent in 1990, while the value of 'commerce and catering,' which in GB1994 newly excluded storage as well as marketing and supply cooperatives (the latter may have been reclassified within commerce), decreased by 16 percent.

A final issue is the treatment of water conservancy. If the data for 1952-1995 by default follow GB1984, as announced in the preface of GDP 1952-95, then water conservancy is included in the primary sector. However, the detailed tertiary sector statistics available for the years since 1990 list water conservancy together with geological prospecting as a separate tertiary sector category (as is the case in GB1994), and tertiary sector value-added for 1990-1995 is identical in the two sources (GDP 1952-95, and the Statistical Yearbook sources of the detailed tertiary sector statistics). ${ }^{88}$ Thus, water conservancy must have been included in the tertiary sector at least since 1990 and the preface of GDP 1952-95 failed to clarify this exception from GB1984. No double-check is possible to see if water conservancy was included in the tertiary sector total prior to 1990 or not. 


\subsubsection{Published after the 2006 benchmark revision}

Since 2004, detailed data on the nominal value-added of the tertiary sector subsectors come in fourteen exhaustive categories following GB2002 (Appendix 7). Revised data for earlier years, following this detailed classification, are not available.

In addition, starting with the 2007 issue, the Statistical Yearbook reports nominal valueadded of six exhaustive tertiary sector subsectors (five subsectors and one summary category "others") following GB2002 for all years since 1978, as well as real growth rates. ${ }^{89}$ GDP 19522004 reports the same type of data for 1952-2004 (Appendix 8). ${ }^{90}$

\subsubsection{Summary of tertiary sector subsector data availability}

To summarize, tertiary sector subsector data are available in four versions:

- 1952-1995: eight exhaustive subsectors (variation of GB1984);

- 1990-2003: twelve exhaustive subsectors (GB1994, except that agricultural services are included in the tertiary sector rather than in the primary sector);

- 2004-2011: fourteen exhaustive subsectors (GB2002), post-economic census $(2004,2008)$ values;

- 1952-2011: six exhaustive subsectors (GB2002 for five subsectors, with residual sixth subsector), post-economic census $(2004,2008)$ values.

\subsection{Value-added of the directly reporting industrial enterprises}

Output data for the years through 1992 follow GB1984. Exhaustive current price GOV and net material product data are available for the years 1980 and 1984-1992 in the Industrial Yearbook 1993. The Statistical Yearbook series prior to the 1993 issue covers similar data though not always with the same degree of sectoral details. Exhaustive sectoral value-added data on the DRIEs are available for 1992 in the Statistical Yearbook 1993. These data are not reported here.

Output data on the DRIEs according to GB1994 are available for the years 1993-2002 (Appendix 9). The output variables are GOV in 1990 constant prices, nominal GOV, and nominal value-added. The definition of GOV changed in 1995, and that of the DRIEs in 1998.

Since 2003, output data are classified according to GB2002; Appendix 10 reports the 20032007 value-added data. Value-added was not published by sector for 2004 but can be approximated by multiplying the available $2004 \mathrm{GOV}$ data by the sector-specific average of the 2003 and 2005 ratios of value-added to GOV. Value-added data end in 2007. The number of enterprises rose drastically in 2004 which suggests a de facto larger coverage of DRIEs since 2004 (following the economic census of 2004); a slight redefinition of DRIEs occurred in 2007, and the size criterion for inclusion in the group of DRIEs changed from $5 \mathrm{~m}$ to $20 \mathrm{~m}$ in 2011 . The series 'GOV in 1990 constant prices' ended with the 2003 data. Nominal GOV data continue to be available, for 2003-2011 (Appendix 11). The relevant industry-specific ex-factory price indices of industrial products, available for the years since 2002, are reported in Appendix 12. 


\subsection{Expenditure and income data}

Appendix 13 reports the nominal expenditure data published after the 2006 benchmark revision (including the 2010 benchmark revision) and the limited real growth data that are available. Appendix 14 reports all available income data, pre-and post-economic census. These values are summed provincial values.

\section{CONCLUSIONS}

This manuscript documented the availability of official Chinese data on nominal values and real growth rates for value-added, expenditures, and income, as well as on output of the DRIEs. It discussed the quality of these data and identified series suitable for use in economic analysis.

A number of conclusions emerge:

- When in doubt, the most recently published value-added and expenditure data are likely to be the over time most consistently defined series, and likely the most reliable series.

- A consistent set of income data is not available. One may want to use one's judgment and opt for relatively constant income shares of the four components in income over timefor example, through 1998—and/or impose a linear trend—for example, between 1998 and 2011.

- Output data for the DRIEs experience a number of breaks due to changes in enterprise coverage, in sectoral classification system, and in the coverage of output variables. Output of the DRIEs is best examined for different periods separately (such as using value-added for 1993-1997, 1998-2002, 2003, and 2004-2006, and GOV for 2007-2010, and 2011).

- In combining output data with data on other variables, such as employment or investment, caution is required to ensure that the data that are being matched follow the same classification system.

- The official data are beset by a variety of problems, documented throughout this manuscript. This includes, for example, the size of revisions to value-added, expenditures, and income in the 2006 benchmark revision, the reorganization of data (such as the reshuffling of rural vs. urban household consumption, and of household vs. government consumption), and the revisions to implicit deflators.

- The values of the deflators of 1989 and 1998 appear severe underestimates, with real growth rates then being overestimated. 1989 is the year of the Tian'anmen Massacre, and 1998 the first year of SOE reform.

- Real growth rates appear significantly manipulated in the 2006 benchmark revision. NBS staff could be following a reliable "gut feeling" as to what is plausible in deciding not to make adjustments to real growth rates to the extent indicated by revised nominal values and original deflators. But that would only go to show that the published values are rather haphazard values.

- Speculating about the reasons for various data problems, these could include the following. (i) The data on the early reform period may miss out on economic activities that at the time were not included in the official output measures (and the retrospective 
revisions may not do full justice to the missing activities). (ii) The data on the recent years may be of poor quality because of the increasingly diverse and unregulated character of the economy; the NBS's difficulty in capturing economic activities in smaller, non-state units becomes more relevant in recent years. (iii) The fact that DRIE value-added of 2007 (as reported in the industry statistics) exceeded the industrial valueadded of the larger set of DRIEs and non-DRIEs together (as reported in the NIPA) points at severe difficulties of the NBS in measuring industrial value-added even at a degree of up to, perhaps $+/-20 \%$ accuracy; ending the publication of DRIE value-added with the 2007 value is not a promising solution to the problem.

The data difficulties should not deter researchers and other consumers of Chinese statistics from using these data. Rather, they should encourage data users to inform themselves about the limitations of the data, and caution against drawing conclusions from minor variations in data values. 
Table 1. Value-Added, Expenditures, Income: Key Data Sources and Their Coverage

\begin{tabular}{|c|c|c|c|c|c|c|}
\hline & \multicolumn{2}{|l|}{ Statistical Yearbook } & \multicolumn{2}{|c|}{ GDP 1952-95 and GDP 1996-2002 } & \multicolumn{2}{|c|}{$\begin{array}{c}\text { GDP 1952-2004 (incorporates } 2006 \\
\text { benchmark revision) }\end{array}$} \\
\hline & nominal values & $\begin{array}{l}\text { real } \\
\text { growth }\end{array}$ & nominal values & real growth & nominal values & $\begin{array}{l}\text { real } \\
\text { growth }\end{array}$ \\
\hline \multicolumn{7}{|l|}{$\begin{array}{l}\text { Production } \\
\text { approach }\end{array}$} \\
\hline Total & $\begin{array}{l}\text { since } 1978 \text {, published } \\
\text { starting with } 1988 \text { issue }\end{array}$ & $\begin{array}{l}\text { same as } \\
\text { on left }\end{array}$ & $\begin{array}{l}\text { 1952-1995; 1996-02 } \\
\text { [also by province] }\end{array}$ & $\begin{array}{l}\text { same as on } \\
\text { left }\end{array}$ & $\begin{array}{l}\text { 1952-2004 } \\
\text { [by province 1993-2004] }\end{array}$ & $\begin{array}{l}\text { same as } \\
\text { on left }\end{array}$ \\
\hline $\begin{array}{l}\text { Main } \\
\text { economic } \\
\text { sectors }^{\mathrm{a}}\end{array}$ & $\begin{array}{l}\text { since 1978, published } \\
\text { starting with } 1988 \text { issue, no } \\
\text { subcategories of secondary } \\
\text { sector before } 1990 \text { issue, } \\
\text { and of tertiary sector before } \\
1991 \text { issue }\end{array}$ & $\begin{array}{l}\text { same as } \\
\text { on left }\end{array}$ & $\begin{array}{l}\text { 1952-1995 and } 1996-02 \text { with } \\
\text { secondary sector breakdown } \\
\text { into industry and construction } \\
\text { and two tertiary sector } \\
\text { subsectors transport and } \\
\text { commerce [also by province] }\end{array}$ & $\begin{array}{l}\text { same as on } \\
\text { left }\end{array}$ & $\begin{array}{l}\text { 1952-2004 with } \\
\text { secondary sector } \\
\text { breakdown into industry } \\
\text { and construction } \\
\text { [by province 1993-2004] }\end{array}$ & $\begin{array}{l}\text { same as } \\
\text { on left }\end{array}$ \\
\hline $\begin{array}{l}\text { Detailed } \\
\text { tertiary } \\
\text { sector } \\
\text { classify- } \\
\text { cation }^{\mathrm{b}}\end{array}$ & $\begin{array}{l}13 \text { subsectors for } 1990- \\
2003 \text {, published starting } \\
\text { with } 1998 \text { issue; } 14 \text { since } \\
2004 \text {, starting with } 2006 \\
\text { issue; } 6 \text { since } 1978 \text {, starting } \\
\text { with } 2006 \text { issue }\end{array}$ & $\begin{array}{l}\text { same as } \\
\text { on left } \\
\text { for } 13 \\
\text { and } 6\end{array}$ & $\begin{array}{l}12 \text { subsectors for } 1990-1995 ; 13 \\
\text { subsectors for } 1996-02 \text { [also by } \\
\text { province] }\end{array}$ & $\begin{array}{l}\text { same as on } \\
\text { left }\end{array}$ & $\begin{array}{l}6 \text { subsectors for } 1952- \\
2004,14 \text { subsectors with } \\
\text { sub-subsectors for } 2004 \\
\text { [by province: } 5 \\
\text { subsectors for } 1993- \\
2004 \text { ] }\end{array}$ & $\begin{array}{l}\text { same as } \\
\text { on left } \\
\text { for } 6 \\
\text { [prov.: } \\
\text { 5] sub- } \\
\text { sectors }\end{array}$ \\
\hline $\begin{array}{l}\text { Within } \\
\text { industry: } \\
\text { industrial } \\
\text { sectors }^{c}\end{array}$ & $\begin{array}{l}\text { only for DRIEs: nominal } \\
\text { value-added (ending with } \\
\text { the } 2007 \text { data) and GOV for } \\
\text { most years since } 1992\end{array}$ & n.a. & n.a. & n.a. & $\begin{array}{l}39 \text { subsectors in 2004, not } \\
\text { limited to DRIEs (data on } \\
\text { all two-digit sectors / sub- } \\
\text { sectors across economy) }\end{array}$ & n.a. \\
\hline $\begin{array}{l}\text { Expenditure } \\
\text { approach }^{\mathrm{d}}\end{array}$ & $\begin{array}{l}\text { since 1978, published } \\
\text { starting with } 1995 \text { issue; no } \\
\text { separate export and import } \\
\text { data, only net export data }\end{array}$ & n.a. & $\begin{array}{l}\text { 1952-95: only consumption and } \\
\text { gross capital formation (and } \\
\text { their subcategories) } \\
\text { [also by province; incl. a total } \\
\text { expenditure value and net } \\
\text { exports, also separate export/ } \\
\text { import data for some years] } \\
\text { 1996-02: same, but incl. a total } \\
\text { and net export data [provincial } \\
\text { data come with separate export/ } \\
\text { import data for some years] }\end{array}$ & $\begin{array}{l}\text { 1952-95, } \\
\text { 1996-02: } \\
\text { only for } \\
\text { consump- } \\
\text { tion and } \\
\text { gross } \\
\text { capital } \\
\text { formation } \\
\text { (and } \\
\text { subcatego- } \\
\text { ries) }\end{array}$ & $\begin{array}{l}\text { 1952-2004 (without } \\
\text { separate export/import } \\
\text { data, only net exports) } \\
\text { [also by province 1993- } \\
\text { 2004] }\end{array}$ & $\begin{array}{l}\text { same as } \\
\text { on left } \\
\text { but not } \\
\text { for net } \\
\text { exports } \\
\text { (or } \\
\text { exports/ } \\
\text { imports) }\end{array}$ \\
\hline Income & only provincial data, starting & n.a. & only provincial data, starting & n.a. & provincial data only, for & n.a. \\
\hline
\end{tabular}




$\begin{array}{ll}\text { approach }^{f} & \text { with } 1993 \text { data in } 1995 \text { issue } \\ & \text { [no 1995, 2004, and } 2008 \\ & \text { data] }\end{array}$

data] with 1978 data, with a

breakdown according to main

economic sectors, including

industry, construction, and 10

(1978-95) or 12 (1996-2002)

tertiary sector subsectors
1993-2004, with a

breakdown according to

main economic sectors,

including industry,

construction, and 5

tertiary sector subsectors

n.a.: not available.

a Main (economic) sectors: primary sector, secondary sector (with a breakdown into industry and construction), tertiary sector (in the Statistical Yearbook series through the 2005 data with a breakdown into 'transport and communication,' 'commerce and catering' (2005 data: following the new classification GB2002) and an implicit category other services).

b The detailed tertiary sector classification in GDP 1952-95 and in GDP 1996-2002 de facto follows GB1994 except that it, further, includes "services for farming, forestry, animal husbandry, and fisheries," which in GB1994 are part of the primary sector. In GDP 1952-95, "government agencies, party agencies and social organizations” and “others” are combined into one category. GDP 1952-2004 follows GB2002.

c For the years 1980-84, the Statistical Yearbook series reports GOV data on 13 to 14 sectors as well as a total (with limited enterprise coverage, for details see Carsten Holz and Yi-min Lin, 2001a); in the period 1985 through 1992, the Statistical Yearbook series reports GOV (and data on various balance sheet and profit and loss account items) for the DRIEs in each of up to 40 industrial sectors (apart from a "total" that may further comprise the military industry, and perhaps some residual “other” item or a group of smaller sectors); value-added values are available since 1992 (and net material product values for 1992 and earlier years. In the period 1993 through 1997, the industry classification covers 39 individual sectors (with possibly only the military industry omitted); beginning in 1998, the coverage extends to 37 industrial sectors, and since 2003 to 39 industrial sectors. The Industrial Yearbook series reports similar data. For example, the Industrial Yearbook 1994,1995 , and 1998 (with no 1996 and 1997 issues) report the same data as the Statistical Yearbook on 37 sectors for 1993, 1994, and 1997, including by province (unlike in the Statistical Yearbook, which reports industrial sectoral data at the national level only). The Industrial Yearbook issues of 2001 through 2004 report on 37 sectors in 1999-2002 and 39 industrial sectors in 2003; provincial sectoral data are only available for 25 sectors. The Industrial Census 1995 volumes have detailed data for 1995, the Economic Census 2004 and 2008 volumes for 2004 and 2008 (on GOV, not value-added). The Statistical Yearbook of a particular year in its industry section (not in the NIPA section) reports the industry data of the previous year only (i.e., no earlier data). The Industrial Yearbook of a particular year also reports the industry data of the previous year only, except for the 1998 issue which has data for 1996 and 1997, and for the 2001 issue which has data for 1999 and 2000. The Industrial Yearbook 1993 covers 40 sectors for 1980 and 1984 1992. Industry, Transport, and Energy 50 Years reports value-added by sector for 1993-1999, and net material product by sector for 1985-1992; the Statistical Yearbook and Industrial Yearbook series together report the data of the same (and other) years.

d Total, with breakdown into consumption (household [rural, urban], government), gross capital formation (gross fixed capital formation, inventory investment), exports, and imports.

e Starting with the 1998 issue, data on the real growth rate of per capita household consumption are available for the years 1978, 1980, 1985, and 1987 on. (Later issues drop values of some of the earlier years.)

f Total, with breakdown into labor remuneration (compensation of employees), depreciation, net taxes on production, and operating surplus. 
Table 2. Three Approaches to the Calculation of GDP (values in \%)

\begin{tabular}{|c|c|c|c|c|c|c|c|c|c|c|c|c|c|c|c|}
\hline & \multicolumn{3}{|c|}{1993} & \multicolumn{3}{|c|}{1995} & \multicolumn{3}{|c|}{2000} & \multicolumn{3}{|c|}{2003} & \multicolumn{3}{|c|}{2007} \\
\hline & $\mathrm{P} / \mathrm{E}$ & $\mathrm{P} / \mathrm{I}$ & $\mathrm{E} / \mathrm{I}$ & $\mathrm{P} / \mathrm{E}$ & $\mathrm{P} / \mathrm{I}$ & $\mathrm{E} / \mathrm{I}$ & $\mathrm{P} / \mathrm{E}$ & $\mathrm{P} / \mathrm{I}$ & $\mathrm{E} / \mathrm{I}$ & $\mathrm{P} / \mathrm{E}$ & $\mathrm{P} / \mathrm{I}$ & $\mathrm{E} / \mathrm{I}$ & $\mathrm{P} / \mathrm{E}$ & $\mathrm{P} / \mathrm{I}$ & $\mathrm{E} / \mathrm{I}$ \\
\hline National & 100 & & & 98 & & & 100 & & & 96 & & & 95 & & \\
\hline Beijing & 100 & 100 & 100 & 82 & 100 & 122 & 100 & 100 & 100 & 100 & 100 & 100 & 100 & 100 & 100 \\
\hline Tianjin & 100 & 100 & 100 & 100 & 100 & 100 & 100 & 100 & 100 & 100 & 100 & 100 & 100 & 100 & 100 \\
\hline Hebei & 100 & 100 & 100 & 100 & 100 & 100 & 100 & 100 & 100 & 100 & 100 & 100 & 100 & 100 & 100 \\
\hline Shanxi & 100 & 100 & 100 & 100 & 100 & 100 & 100 & 100 & 100 & 98 & 100 & 102 & 100 & 100 & 100 \\
\hline Inner Mon. & 100 & 100 & 100 & 102 & 100 & 98 & 101 & 100 & 99 & 99 & 100 & 101 & 100 & 100 & 100 \\
\hline Liaoning & 100 & 100 & 100 & 100 & 100 & 100 & 100 & 100 & 100 & 100 & 100 & 100 & 100 & 100 & 100 \\
\hline Jilin & 100 & 100 & 100 & 99 & 100 & 101 & 98 & 100 & 102 & 97 & 100 & 103 & 94 & 100 & 106 \\
\hline Heilongj. & 100 & 100 & 100 & 100 & 100 & 100 & 101 & 100 & 99 & 105 & 100 & 96 & 100 & 100 & 100 \\
\hline Shanghai & 100 & 100 & 100 & 100 & 100 & 100 & 100 & 100 & 100 & 100 & 100 & 100 & 100 & 100 & 100 \\
\hline Jiangsu & 100 & 100 & 100 & 101 & 100 & 99 & 101 & 100 & 99 & 100 & 100 & 100 & 100 & 100 & 100 \\
\hline Zhejiang & 100 & 100 & 100 & 99 & 100 & 101 & 100 & 100 & 100 & 100 & 100 & 100 & 100 & 100 & 100 \\
\hline Anhui & 100 & 100 & 100 & 100 & 100 & 100 & 100 & 100 & 100 & 100 & 100 & 100 & 100 & 100 & 100 \\
\hline Fujian & 100 & 100 & 100 & 100 & 100 & 100 & 101 & 100 & 99 & 101 & 100 & 99 & 99 & 100 & 101 \\
\hline Jiangxi & 100 & 100 & 100 & 99 & 100 & 101 & 101 & 100 & 99 & 100 & 100 & 100 & 100 & 100 & 100 \\
\hline Shandong & 100 & 100 & 100 & 102 & 100 & 98 & 100 & 100 & 100 & 100 & 100 & 100 & 100 & 100 & 100 \\
\hline Henan & 100 & 100 & 100 & 100 & 100 & 100 & 100 & 100 & 100 & 100 & 100 & 100 & 100 & 100 & 100 \\
\hline Hubei & 99 & 100 & 101 & 98 & 100 & 102 & 103 & 100 & 97 & 100 & 100 & 100 & 97 & 100 & 103 \\
\hline Hunan & 100 & 100 & 100 & 100 & 100 & 100 & 100 & 100 & 100 & 100 & 100 & 100 & 100 & 100 & 100 \\
\hline Guangdong & 100 & 100 & 100 & 94 & 100 & 107 & 100 & 100 & 100 & 100 & 100 & 100 & 100 & 100 & 100 \\
\hline Guangxi & 100 & 100 & 100 & 100 & 100 & 100 & 100 & 100 & 100 & 100 & 100 & 100 & 100 & 100 & 100 \\
\hline Hainan & 100 & 100 & 100 & 100 & 100 & 100 & 100 & 100 & 100 & 100 & 100 & 100 & 100 & 100 & 100 \\
\hline Chongqing & & & & & & & 99 & 100 & 101 & 97 & 100 & 103 & 96 & 100 & 104 \\
\hline Sichuan & 100 & 100 & 100 & 100 & 100 & 100 & 100 & 100 & 100 & 100 & 100 & 100 & 100 & 100 & 100 \\
\hline Guizhou & 100 & 100 & 100 & 100 & 100 & 100 & 100 & 100 & 100 & 100 & 100 & 100 & 100 & 100 & 100 \\
\hline Yunnan & 100 & 100 & 100 & 100 & 100 & 100 & 100 & 100 & 100 & 100 & 100 & 100 & 100 & 100 & 100 \\
\hline Tibet & 124 & 100 & 81 & 80 & 100 & 124 & 98 & 100 & 102 & 100 & 100 & 100 & 100 & 100 & 100 \\
\hline Shaanxi & 100 & 100 & 100 & 100 & 100 & 100 & 100 & 100 & 100 & 100 & 100 & 100 & 100 & 100 & 100 \\
\hline Gansu & 100 & 100 & 100 & 100 & 100 & 100 & 100 & 100 & 100 & 100 & 100 & 100 & 100 & 100 & 100 \\
\hline Qinghai & 100 & 100 & 100 & 100 & 100 & 100 & 104 & 100 & 96 & 100 & 100 & 100 & 100 & 100 & 100 \\
\hline Ningxia & 100 & 100 & 100 & 100 & 100 & 100 & 100 & 100 & 100 & 100 & 100 & 100 & 100 & 100 & 100 \\
\hline Xinjiang & 100 & 100 & 100 & 101 & 100 & 99 & 100 & 100 & 100 & 100 & 100 & 100 & 100 & 100 & 100 \\
\hline Min & 99 & 100 & 81 & 80 & 100 & 98 & 98 & 100 & 96 & 97 & 100 & 96 & 94 & 100 & 100 \\
\hline Max & 124 & 100 & 101 & 102 & 100 & 124 & 104 & 100 & 102 & 105 & 100 & 103 & 100 & 100 & 106 \\
\hline SD & 4 & 0.0 & 3.5 & 4.8 & 0.0 & 5.9 & 1.1 & 0.0 & 1.1 & 1.3 & 0.0 & 1.3 & 1.3 & 0.0 & 1.4 \\
\hline Mean & 101 & 100 & 99 & 99 & 100 & 102 & 100 & 100 & 100 & 100 & 100 & 100 & 100 & 100 & 100 \\
\hline
\end{tabular}

P, E, I: Provincial GDP calculated using the production approach, expenditure approach, and income approach. P/E: Summed sectoral value-added divided by (total) expenditures. P/I and E/I are similarly defined.

1993 is the first year for which the Statistical Yearbook reports provincial expenditures and income, 2003 the latest year for which the Statistical Yearbook (2004 or 2005) reports (provincial) income approach data before the post-economic census benchmark revision. All 1993 data are from the Statistical Yearbook 1995 which incorporates the benchmark revision following the 1993 tertiary sector census.

Sources: national values: Statistical Yearbook 1995, pp. 32, 36; 1996, pp. 42, 46; 2001, pp. 49, 61; 2004, pp. 53, 65; 2008, pp. 37, 54; provincial values: Statistical Yearbook 1995, pp. 34, 38, 41; 1996, p. 43; 1997, p. 48; 2001, pp. 57, 60, 63; 2004, pp. 61, 64, 67; 2008, pp. 50, 53, 58; GDP 1952-95, p. 79. 


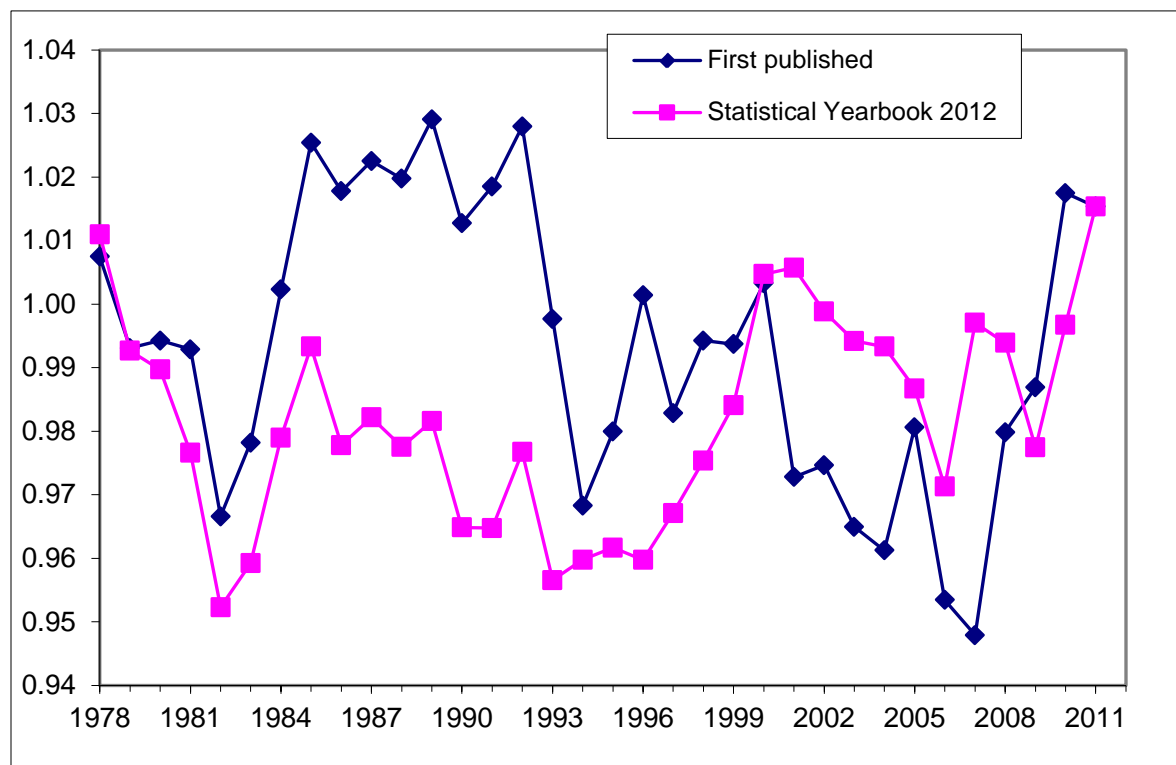

Sources: first published values from Statistical Yearbook 1995 (pp. 32, 36) for all years through 1994, and then each subsequent year's Statistical Yearbook. (Expenditure approach values became available in the Statistical Yearbook 1995 only, with data from 1978, and this source does not report production approach values of 1979 and 1981-83, but the Statistical Yearbook 1998, p. 55, does, with identical production approach values for 1978, 1980, and 1984 as in the Statistical Yearbook 1995); Statistical Yearbook 2010, pp. 44, 61.

Figure 1. Nominal GDP: Production Value-Added Divided by Expenditure Value 
Table 3. Summed Provincial Value-Added Divided by National Value-Added

\begin{tabular}{|c|c|c|c|c|c|c|c|c|c|c|}
\hline \multicolumn{11}{|c|}{ A. Production approach } \\
\hline & \multicolumn{2}{|c|}{$\begin{array}{c}\text { Total } \\
\text { (GDP) }\end{array}$} & $\begin{array}{l}\text { Primary } \\
\text { sector }\end{array}$ & \multicolumn{2}{|c|}{$\begin{array}{l}\text { Secondary } \\
\text { sector }\end{array}$} & \multicolumn{2}{|c|}{$\begin{array}{c}\# \\
\text { Industry }\end{array}$} & $\begin{array}{c}\# \\
\text { Construction }\end{array}$ & \multicolumn{2}{|c|}{$\begin{array}{l}\text { Tertiary } \\
\text { sector }\end{array}$} \\
\hline $1993^{\mathrm{a}}$ & \multicolumn{2}{|c|}{1.091} & 1.028 & & 1.004 & \multicolumn{2}{|c|}{1.001} & \multicolumn{2}{|c|}{1.019} & 1.307 \\
\hline 1994 & \multicolumn{2}{|c|}{1.013} & 0.982 & & 1.013 & \multicolumn{2}{|r|}{1.024} & \multicolumn{2}{|c|}{0.946} & 1.019 \\
\hline 1995 & \multicolumn{2}{|c|}{0.989} & 0.996 & & 0.957 & \multicolumn{2}{|r|}{ n.a. } & \multicolumn{2}{|c|}{ n.a. } & 1.034 \\
\hline 1996 & \multicolumn{2}{|c|}{1.000} & 1.004 & & 0.950 & \multicolumn{2}{|c|}{0.960} & \multicolumn{2}{|c|}{0.886} & 1.077 \\
\hline 1997 & \multicolumn{2}{|c|}{1.029} & 1.047 & & 0.981 & \multicolumn{2}{|c|}{0.994} & \multicolumn{2}{|c|}{0.898} & 1.093 \\
\hline 1998 & \multicolumn{2}{|c|}{1.043} & 1.018 & & 0.997 & \multicolumn{2}{|c|}{0.998} & 0.99 & & 1.123 \\
\hline 1999 & & 070 & 1.011 & & 1.008 & & 1.003 & 1.04 & & 1.194 \\
\hline 2000 & & 087 & 1.044 & & 1.007 & & 0.998 & 1.06 & & 1.232 \\
\hline 2001 & & 113 & 1.064 & & 1.016 & & 1.005 & 1.08 & & 1.283 \\
\hline 2002 & & 126 & 1.006 & & 1.038 & & 1.023 & 1.13 & & 1.316 \\
\hline 2003 & & 156 & 1.005 & & 1.084 & & 1.069 & 1.17 & & 1.336 \\
\hline 2004 & & 193 & 1.006 & & 1.139 & & 1.128 & 1.21 & & 1.370 \\
\hline 2005 & & 080 & 0.997 & & 1.113 & & 1.111 & 1.13 & & 1.067 \\
\hline 2006 & & 096 & 1.000 & & 1.121 & & 1.123 & 1.10 & & 1.093 \\
\hline 2007 & & 105 & 1.017 & & 1.140 & & 1.149 & 1.07 & & 1.087 \\
\hline 2008 & & 088 & 0.993 & & 1.142 & & 1.154 & 1.04 & & 1.051 \\
\hline 2009 & & 073 & 1.000 & & 1.141 & & 1.165 & 1.00 & & 1.017 \\
\hline 2010 & & 089 & 1.000 & & 1.173 & & 1.202 & 1.00 & & 1.019 \\
\hline 2011 & & 103 & 0.999 & & 1.197 & & 1.230 & 1.00 & & 1.025 \\
\hline B. Exp & & proach & & & & & & & & \\
\hline & $\begin{array}{c}\text { Total } \\
\text { (GDP) }\end{array}$ & $\begin{array}{l}\text { Final } \\
\text { con- } \\
\text { sump- } \\
\text { tion }\end{array}$ & $\begin{array}{c}\# \\
\text { House- } \\
\text { hold } \\
\text { cons. }\end{array}$ & $\begin{array}{l}\text { \#\# } \\
\text { Rural } \\
\text { house- } \\
\text { holds }\end{array}$ & $\begin{array}{c}\text { \#\# } \\
\text { Urban } \\
\text { house- } \\
\text { holds }\end{array}$ & $\begin{array}{c}\# \\
\text { Gov- } \\
\text { ernment }\end{array}$ & $\begin{array}{l}\text { Gross } \\
\text { capital } \\
\text { forma- } \\
\text { tion }\end{array}$ & $\begin{array}{c}\text { \# } \\
\text { Fixed } \\
\text { capital } \\
\text { form. }\end{array}$ & $\begin{array}{c}\# \\
\text { Change } \\
\text { in inven- } \\
\text { tories }\end{array}$ & $\begin{array}{c}\text { Net } \\
\text { exports }\end{array}$ \\
\hline $\begin{array}{l}1993 \\
\end{array}$ & 0.990 & 0.911 & 0.924 & 0.978 & 0.869 & 0.868 & 1.038 & 0.916 & 1.803 & -0.665 \\
\hline 1994 & 0.978 & 0.909 & 0.920 & 0.989 & 0.855 & 0.867 & 1.084 & 0.911 & 2.998 & 0.811 \\
\hline 1995 & 0.979 & 0.892 & 0.887 & 0.933 & 0.842 & 0.909 & 1.106 & 0.964 & 2.063 & 1.086 \\
\hline 1996 & 0.999 & 0.923 & n.a. & n.a. & n.a. & n.a. & 1.120 & n.a. & n.a. & 0.841 \\
\hline 1997 & 1.009 & 0.922 & 0.894 & 0.924 & 0.864 & 1.041 & 1.160 & 0.994 & 2.640 & 0.849 \\
\hline 1998 & 1.035 & 0.942 & 0.912 & 0.955 & 0.873 & 1.059 & 1.210 & 1.034 & 3.450 & 0.708 \\
\hline 1999 & 1.061 & 0.942 & 0.902 & 0.950 & 0.861 & 1.095 & 1.245 & 1.061 & 6.564 & 1.196 \\
\hline 2000 & 1.088 & 0.960 & 0.910 & 0.948 & 0.879 & 1.143 & 1.278 & 1.067 & -17.365 & 1.470 \\
\hline 2001 & 1.080 & 0.985 & 0.912 & 0.940 & 0.891 & 1.240 & 1.211 & 1.056 & 10.020 & 1.417 \\
\hline 2002 & 1.097 & 1.029 & 0.947 & 0.948 & 0.946 & 1.317 & 1.195 & 1.063 & 30.951 & 1.111 \\
\hline 2003 & 1.115 & 1.064 & 0.965 & 0.943 & 0.980 & 1.420 & 1.198 & 1.095 & 40.715 & 0.795 \\
\hline 2004 & 1.147 & 1.097 & 0.990 & 0.919 & 1.038 & 1.481 & 1.243 & 1.138 & 13.796 & 0.604 \\
\hline 2005 & 1.060 & 1.020 & 1.012 & 1.074 & 0.990 & 1.042 & 1.188 & 1.135 & 3.163 & 0.435 \\
\hline 2006 & 1.049 & 1.029 & 1.020 & 1.055 & 1.007 & 1.054 & 1.200 & 1.178 & 1.709 & 0.325 \\
\hline 2007 & 1.050 & 1.039 & 1.021 & 1.034 & 1.016 & 1.089 & 1.228 & 1.227 & 1.254 & 0.265 \\
\hline 2008 & 1.101 & 1.050 & 1.023 & 1.009 & 1.027 & 1.121 & 1.292 & 1.288 & 1.364 & 0.365 \\
\hline 2009 & 1.062 & 1.034 & 1.010 & 1.021 & 1.007 & 1.098 & 1.217 & 1.235 & 0.858 & -0.327 \\
\hline 2010 & 1.110 & 1.074 & 1.074 & 1.063 & 1.078 & 1.071 & 1.272 & 1.285 & 1.018 & -0.429 \\
\hline 2011 & 1.123 & 1.048 & 1.044 & 1.072 & 1.035 & 1.059 & 1.301 & 1.319 & 0.974 & -0.766 \\
\hline
\end{tabular}


\# denotes a subcategory, \#\# a sub-subcategory. The list of subcategories is exhaustive, as is the list of sub-subcategories.

Data are first published values, in the Statistical Yearbook of the year following the year covered by the data.

a The large downward adjustments to provincial production-income approach GDP in 1993 are due to the fact that 1993 provincial-level data, published a year late, already incorporate the retrospective upward revisions to GDP following the 1993 tertiary sector census, while the nationwide data do not.

1993 is the first year in which GDP data calculated according to the expenditure approach became available in the Statistical Yearbook. Provincial-level expenditure data for 1993 and 1994 were published only in the Statistical Yearbook 1995 and 1996, i.e. one year late; this implies that provincial-level data could be revised data (while nationwide data are those as first published). In all other instances, both provincial and nationwide data are as first published; no revised provincial data are usually published.

Sources: Statistical Yearbook 1994, pp. 32, 35; 1995, pp. 32-4, 36-40; 1996, pp. 42-44, 46-50; 1997, pp. 42, 44, 46-50; 1998, pp. 55, 62f., 67-71; 1999, pp. 55, 63, 67-71; 2000, pp. 53, 60f., 65-9; 2001, pp. 49, 57, 60-5; 2002, pp. 51, 59, 63-7; 2003, pp. 55, 63, 67-71; 2004, pp. 61, 67-9; 2005, pp. 59, 65-7; 2006, pp. 57, 61, 72f.; 2007, pp. 37, 42, 54f.; 2008, pp. 37, 42, 54f.; 2009, pp. 38, 43, 55f.; 2010, pp. 44, 49, 61f.; 2011, pp. 44, 49, 61f.; GDP 1952-96, p. 106 (for 1996 expenditure approach provincial-level data). 
Table 4. Annual Revisions to National Value-Added

\begin{tabular}{lccrrrr}
\hline \multicolumn{2}{c}{ A. Production approach } & \multicolumn{2}{c}{ Total } \\
& (GDP) & $\begin{array}{c}\text { Primary } \\
\text { sector }\end{array}$ & $\begin{array}{c}\text { Secondary } \\
\text { sector }\end{array}$ & $\begin{array}{c}\# \\
\text { Industry }\end{array}$ & $\begin{array}{c}\# \\
\text { Construction }\end{array}$ & $\begin{array}{c}\text { Tertiary } \\
\text { sector }\end{array}$ \\
\hline 1993 & 1.104 & 1.035 & 1.011 & 1.000 & 1.085 & 1.335 \\
1994 & 1.039 & 1.002 & 1.052 & 1.055 & 1.039 & 1.043 \\
1995 & 1.004 & 1.000 & 1.013 & 1.015 & 1.000 & 0.992 \\
1996 & 0.990 & 0.997 & 1.000 & 1.000 & 1.000 & 0.968 \\
1997 & 0.996 & 1.017 & 1.012 & 1.021 & 0.959 & 0.958 \\
1998 & 0.987 & 0.997 & 0.998 & 0.999 & 0.994 & 0.964 \\
1999 & 1.002 & 1.001 & 1.004 & 1.003 & 1.005 & 1.000 \\
2000 & 1.001 & 1.029 & 0.988 & 0.987 & 0.995 & 1.007 \\
2001 & 1.014 & 1.055 & 0.993 & 0.995 & 0.987 & 1.028 \\
2002 & 1.004 & 1.000 & 0.990 & 0.988 & 1.000 & 1.027 \\
2003 & 1.001 & 0.990 & 1.000 & 1.000 & 1.000 & 1.008 \\
2004 & 1.168 & 1.009 & 1.021 & 1.038 & 0.908 & 1.487 \\
2005 & 1.004 & 1.000 & 1.004 & 1.004 & 1.000 & 1.006 \\
2006 & 1.005 & 0.972 & 1.000 & 1.000 & 1.000 & 1.021 \\
2007 & 1.031 & 1.019 & 1.028 & 1.030 & 1.018 & 1.038 \\
2008 & 1.044 & 0.991 & 1.019 & 1.009 & 1.098 & 1.090 \\
2009 & 1.001 & 1.000 & 1.000 & 1.000 & 1.000 & 1.003 \\
2010 & 1.001 & 1.000 & 0.999 & 0.999 & 0.998 & 1.003 \\
\hline
\end{tabular}

\begin{tabular}{|c|c|c|c|c|c|c|c|c|c|c|}
\hline \multicolumn{11}{|c|}{ B. Expenditure approach } \\
\hline & $\begin{array}{l}\text { Total } \\
\text { (GDP) }\end{array}$ & $\begin{array}{l}\text { Final } \\
\text { con- } \\
\text { sump- } \\
\text { tion }\end{array}$ & $\begin{array}{c}\quad \# \\
\text { House- } \\
\text { hold } \\
\text { cons. }\end{array}$ & $\begin{array}{c}\text { \#\# } \\
\text { Rural } \\
\text { house- } \\
\text { holds }\end{array}$ & $\begin{array}{c}\text { \#\# } \\
\text { Urban } \\
\text { house- } \\
\text { holds }\end{array}$ & $\begin{array}{c}\# \\
\text { Gov- } \\
\text { ernment }\end{array}$ & $\begin{array}{l}\text { Gross } \\
\text { capital } \\
\text { forma- } \\
\text { tion }\end{array}$ & $\begin{array}{c}\# \\
\text { Fixed } \\
\text { capital } \\
\text { form. }\end{array}$ & $\begin{array}{c}\# \\
\text { Change } \\
\text { in inven- } \\
\text { tories } \\
\end{array}$ & $\begin{array}{l}\text { Net } \\
\text { exports }\end{array}$ \\
\hline 1994 & 1.005 & 1.005 & 1.005 & 1.028 & 0.984 & 1.005 & 1.017 & 0.969 & 1.546 & 0.720 \\
\hline 1995 & 0.984 & 0.962 & 0.968 & 0.970 & 0.966 & 0.939 & 1.012 & 0.988 & 1.179 & 1.105 \\
\hline 1996 & 0.998 & 0.996 & 0.987 & 1.007 & 0.966 & 1.035 & 1.000 & 1.000 & 1.000 & 1.000 \\
\hline 1997 & 0.985 & 0.973 & 0.965 & 0.972 & 0.958 & 1.009 & 0.996 & 0.979 & 1.153 & 1.041 \\
\hline 1998 & 0.989 & 1.000 & 1.000 & 1.000 & 1.000 & 1.000 & 0.972 & 0.981 & 0.865 & 1.000 \\
\hline 1999 & 1.003 & 1.001 & 0.998 & 1.003 & 0.995 & 1.010 & 1.007 & 1.000 & 1.201 & 1.000 \\
\hline 2000 & 1.003 & 1.000 & 1.000 & 0.990 & 1.007 & 1.000 & 1.008 & 1.000 & 0.336 & 1.000 \\
\hline 2001 & 1.000 & 1.000 & 0.999 & n.a. & n.a. & 1.000 & 1.000 & 1.000 & 1.000 & 1.000 \\
\hline 2002 & 1.004 & 1.007 & 1.007 & 1.004 & 1.009 & 1.006 & 0.999 & 0.994 & 2.066 & 1.000 \\
\hline 2003 & 1.002 & 1.001 & 1.000 & 1.000 & 1.000 & 1.003 & 1.003 & 1.001 & 1.866 & 0.998 \\
\hline 2004 & 1.126 & 1.154 & 1.082 & 0.734 & 1.319 & 1.411 & 1.100 & 1.044 & 7.732 & 1.000 \\
\hline 2005 & 1.011 & 1.009 & 1.004 & 1.011 & 1.002 & 1.023 & 1.014 & 0.998 & 1.595 & 1.000 \\
\hline 2006 & 1.002 & 1.002 & 1.004 & 1.000 & 1.006 & 0.994 & 1.003 & 1.000 & 1.076 & 1.000 \\
\hline 2007 & 0.999 & 1.003 & 1.003 & 1.000 & 1.004 & 1.002 & 0.996 & 1.002 & 0.885 & 1.000 \\
\hline 2008 & 1.026 & 1.022 & 1.020 & 1.011 & 1.024 & 1.025 & 1.035 & 1.015 & 1.383 & 1.004 \\
\hline 2009 & 1.004 & 1.008 & 1.000 & 1.000 & 1.000 & 1.029 & 1.000 & 1.000 & 1.000 & 1.000 \\
\hline 2010 & 1.022 & 1.039 & 1.056 & 1.035 & 1.062 & 0.995 & 1.010 & 1.007 & 1.068 & 0.961 \\
\hline
\end{tabular}

All ratios through 2003 are obtained as national value published in the Statistical Yearbook 2005 divided by the national value as first published in the then current year Statistical Yearbook. After 2003, all data are from the Statistical Yearbook series (second-most recent year's value in this issue divided by most recent value in the previous issue). For further notes and data sources see previous table. 
Year 1993 production approach GDP was retrospectively revised upward by 10 percent largely because of a 33.45 percent upward revision to tertiary sector value-added following the 1993 tertiary sector census. Tertiary sector value-added was first revised in the Statistical Yearbook 1995, and then a second time (which is unusual), by a very minor amount, in the Statistical Yearbook 1996. (The value in the latter has been reprinted in later editions.) 
Table 5. GDP Real Growth Rates (in \%)

\begin{tabular}{|c|c|c|c|c|c|c|c|c|}
\hline & \multicolumn{4}{|c|}{ Official values } & \multirow{2}{*}{\multicolumn{4}{|c|}{$\begin{array}{l}\text { Constructed series: first implicit deflators, } \\
\text { nominal values from Statistical Yearbook }\end{array}$}} \\
\hline & \multirow{3}{*}{$\begin{array}{l}\text { As first } \\
\text { published }\end{array}$} & \multirow{2}{*}{\multicolumn{3}{|c|}{$\begin{array}{l}\text { As published in } \\
\text { Statistical Yearbook }\end{array}$}} & & & & \\
\hline & & & & & & & & 2012 \\
\hline & & 2005 & 2009 & 2012 & & $\begin{array}{l}\text { in- } \\
\text { adex }\end{array}$ & & $\begin{array}{l}\text { as Törn- } \\
\text { qvist index }\end{array}$ \\
\hline 1987 & 10.4 / 11.1 & 11.6 & 11.6 & 11.6 & & 10.8 & & 10.9 \\
\hline 1988 & 10.4 / 11.2 & 11.3 & 11.3 & 11.3 & & 11.7 & & 11.7 \\
\hline 1989 & $3.5 / 4.3$ & 4.1 & 4.1 & 4.1 & & 3.6 & & 3.3 \\
\hline 1990 & $5.0 / 3.9$ & 3.8 & 3.8 & 3.8 & & 3.8 & & 3.9 \\
\hline 1991 & 7.8 / 8.0 & 9.2 & 9.2 & 9.2 & & 12.2 & & 12.4 \\
\hline 1992 & 13.2 & 14.2 & 14.2 & 14.2 & 17.2 & 17.4 & 17.6 & 17.8 \\
\hline 1993 & 13.4 & 13.5 & 14.0 & 14.0 & 14.5 & 14.8 & 15.5 & 15.8 \\
\hline 1994 & 11.8 & 12.6 & 13.1 & 13.1 & 15.8 & 15.9 & 17.0 & 17.0 \\
\hline 1995 & 10.5 & 10.5 & 10.9 & 10.9 & 10.7 & 10.5 & 11.6 & 11.4 \\
\hline 1996 & 9.6 & 9.6 & 10.0 & 10.0 & 8.5 & 8.2 & 9.4 & 9.1 \\
\hline 1997 & 8.8 & 8.8 & 9.3 & 9.3 & 8.4 & 8.2 & 9.6 & 9.1 \\
\hline 1998 & 7.8 & 7.8 & 7.8 & 7.8 & 6.4 & 6.2 & 8.1 & 7.6 \\
\hline 1999 & 7.1 & 7.1 & 7.6 & 7.6 & 7.3 & 7.2 & 8.9 & 8.6 \\
\hline 2000 & 8.0 & 8.0 & 8.4 & 8.4 & 8.0 & 7.9 & 9.6 & 9.4 \\
\hline 2001 & 7.3 & 7.5 & 8.3 & 8.3 & 8.8 & 8.8 & 10.5 & 10.6 \\
\hline 2002 & 8.0 & 8.3 & 9.1 & 9.1 & 8.4 & 8.4 & 10.1 & 10.2 \\
\hline 2003 & 9.3 & 9.5 & 10.0 & 10.0 & 9.4 & 9.5 & 10.7 & 10.9 \\
\hline 2004 & 9.5 & 9.5 & 10.1 & 10.1 & 9.5 & 9.5 & 10.5 & 11.0 \\
\hline 2005 & 10.2 & & 10.4 & 11.3 & & & 11.3 & 11.4 \\
\hline 2006 & 11.1 & & 11.6 & 12.7 & & & 13.3 & 13.4 \\
\hline 2007 & 11.9 & & 13.0 & 14.2 & & & 16.8 & 16.9 \\
\hline 2008 & 9.0 & & 9.0 & 9.6 & & & 10.2 & 10.2 \\
\hline 2009 & 9.1 & & & 9.2 & & & 9.2 & 9.2 \\
\hline 2010 & 10.4 & & & 10.4 & & & 10.5 & 10.4 \\
\hline 2011 & 9.3 & & & 9.3 & & & 9.3 & 9.3 \\
\hline
\end{tabular}

As first published: individual issues of the Statistical Yearbook series. 1987-1991 data on GDP are not available; for these years, the first figure represents the weighted average of the real growth rates of the three main economic sectors (using previous-year nominal values as weights), the second figure is the one published retrospectively in the Statistical Yearbook 1993, pp. 31f.

Constructed series: first implicit deflator, Statistical Yearbook nominal values: in compiling the Törnqvist index, the nominal growth rates of the three main economic sectors are divided by the corresponding first published implicit deflators in order to obtain these sectors' real growth rates, which are then aggregated into real GDP growth rates using a Törnqvist index with the nominal shares from the Statistical Yearbook as weights. 
Table 6. Pre- versus Post-Economic Census 2004 Nominal Value-Added for 1978-2004

\begin{tabular}{|c|c|c|c|c|c|c|}
\hline & GDP & $\begin{array}{c}\text { Primary } \\
\text { sector }\end{array}$ & $\begin{array}{l}\text { Secondary } \\
\text { sector }\end{array}$ & $\begin{array}{c}\# \\
\text { Industry }\end{array}$ & $\begin{array}{c}\# \\
\text { Construction }\end{array}$ & $\begin{array}{c}\text { Tertiary } \\
\text { sector }\end{array}$ \\
\hline \multicolumn{7}{|c|}{ A. Post-economic census national vs. pre-economic census national values, percentage difference } \\
\hline 1978 & 0.58 & 0.00 & 0.00 & 0.00 & 0.00 & 2.45 \\
\hline 1979 & 0.60 & 0.00 & 0.00 & 0.00 & 0.00 & 2.82 \\
\hline 1980 & 0.62 & 0.00 & 0.00 & 0.00 & 0.00 & 2.88 \\
\hline 1981 & 0.60 & 0.00 & 0.00 & 0.00 & 0.00 & 2.75 \\
\hline 1982 & 0.54 & 0.00 & 0.00 & 0.00 & 0.00 & 2.50 \\
\hline 1983 & 0.48 & 0.00 & 0.00 & 0.00 & 0.00 & 2.12 \\
\hline 1984 & 0.52 & 0.00 & 0.00 & 0.00 & 0.00 & 2.10 \\
\hline 1985 & 0.58 & 0.00 & 0.00 & 0.00 & 0.00 & 2.02 \\
\hline 1986 & 0.72 & 0.00 & 0.00 & 0.00 & 0.00 & 2.48 \\
\hline 1987 & 0.80 & 0.00 & 0.00 & 0.00 & 0.00 & 2.74 \\
\hline 1988 & 0.77 & 0.00 & 0.00 & 0.00 & 0.00 & 2.54 \\
\hline 1989 & 0.49 & 0.00 & 0.00 & 0.00 & 0.00 & 1.54 \\
\hline 1990 & 0.65 & 0.00 & 0.00 & 0.00 & 0.00 & 2.06 \\
\hline 1991 & 0.76 & 0.00 & 0.00 & 0.00 & 0.00 & 2.27 \\
\hline 1992 & 1.07 & 0.00 & 0.00 & 0.00 & 0.00 & 3.12 \\
\hline 1993 & 2.02 & 0.08 & 0.16 & 0.31 & -0.80 & 5.90 \\
\hline 1994 & 3.08 & 0.15 & 0.33 & 0.63 & -1.59 & 9.05 \\
\hline 1995 & 3.96 & 0.23 & 0.50 & 0.94 & -2.38 & 11.96 \\
\hline 1996 & 4.85 & 0.30 & 0.66 & 1.26 & -3.16 & 14.82 \\
\hline 1997 & 6.06 & 0.38 & 0.86 & 1.57 & -3.93 & 17.96 \\
\hline 1998 & 7.73 & 0.45 & 1.00 & 1.89 & -4.69 & 22.27 \\
\hline 1999 & 9.27 & 0.53 & 1.17 & 2.21 & -5.46 & 26.10 \\
\hline 2000 & 10.89 & 0.60 & 1.38 & 2.53 & -6.21 & 30.22 \\
\hline 2001 & 12.68 & 0.68 & 1.56 & 2.85 & -6.96 & 34.61 \\
\hline 2002 & 14.41 & 0.75 & 1.73 & 3.17 & -7.70 & 39.15 \\
\hline 2003 & 15.70 & 0.83 & 1.90 & 3.49 & -8.44 & 43.71 \\
\hline 2004 & 16.81 & 0.90 & 2.10 & 3.81 & -9.17 & 48.71 \\
\hline \multicolumn{7}{|c|}{$\begin{array}{l}\text { B. Summed provincial pre-economic census vs. national pre-economic census values, percentage } \\
\text { difference }\end{array}$} \\
\hline 1993 & -1.17 & -0.66 & -0.77 & 0.09 & -6.08 & -2.08 \\
\hline 1994 & -2.94 & -1.98 & -3.73 & -2.92 & -8.94 & -2.37 \\
\hline 1995 & -1.46 & -0.39 & -5.50 & n.a. & n.a. & 4.24 \\
\hline 1996 & 1.03 & 0.69 & -5.03 & -4.04 & -11.43 & 11.24 \\
\hline 1997 & 3.35 & 2.87 & -3.11 & -2.63 & -6.31 & 14.08 \\
\hline 1998 & 5.66 & 2.17 & -0.08 & -0.09 & -0.02 & 16.48 \\
\hline 1999 & 6.83 & 1.04 & 0.49 & -0.02 & 3.79 & 19.43 \\
\hline 2000 & 8.65 & 1.48 & 1.89 & 1.12 & 7.01 & 22.33 \\
\hline 2001 & 9.71 & 0.84 & 2.27 & 1.09 & 10.15 & 24.79 \\
\hline 2002 & 12.22 & 0.61 & 4.88 & 3.51 & 13.90 & 28.18 \\
\hline 2003 & 15.46 & 1.47 & 8.39 & 6.94 & 17.81 & 32.56 \\
\hline 2004 & 19.26 & 0.62 & 13.89 & 12.77 & 21.29 & 37.00 \\
\hline
\end{tabular}

C. Summed provincial pre-economic census vs. national post-economic census values, percentage difference

$\begin{array}{rrrccrr}1993 & -3.13 & -0.74 & -0.92 & -0.22 & -5.32 & -7.54 \\ 1994 & -5.84 & -2.13 & -4.05 & -3.52 & -7.47 & -10.47 \\ & & 51 & & \end{array}$




\begin{tabular}{|c|c|c|c|c|c|c|}
\hline 1995 & -5.21 & -0.61 & -5.96 & n.a. & n.a. & -6.90 \\
\hline 1996 & -3.64 & 0.39 & -5.66 & -5.23 & -8.54 & -3.12 \\
\hline 1997 & -2.55 & 2.49 & -3.93 & -4.14 & -2.48 & -3.29 \\
\hline 1998 & -1.92 & 1.72 & -1.07 & -1.94 & 4.91 & -4.73 \\
\hline 1999 & -2.24 & 0.51 & -0.67 & -2.18 & 9.78 & -5.29 \\
\hline 2000 & -2.02 & 0.87 & 0.50 & -1.38 & 14.10 & -6.06 \\
\hline 2001 & -2.63 & 0.16 & 0.69 & -1.71 & 18.39 & -7.30 \\
\hline 2002 & -1.92 & -0.15 & 3.10 & 0.33 & 23.41 & -7.89 \\
\hline 2003 & -0.21 & 0.63 & 6.37 & 3.33 & 28.67 & -7.76 \\
\hline 2004 & 2.10 & -0.28 & 11.56 & 8.62 & 33.53 & -7.87 \\
\hline
\end{tabular}

Pre-economic census national values from the Statistical Yearbook 2005 have undergone the typical annual revision one year after they were first published. All Statistical Yearbook data quoted in the table incorporate the benchmark revision following the 1993 tertiary sector census. Pre-economic census provincial values of each year are typically published only once in the Statistical Yearbook series, when they first become available (and thus no revised values are available, although in the early years the provincial data were released a year late, i.e., might incorporate an annual revision). Provincial values would also have been available for 1991 and 1992 (and for provincial GDP only, without subcategories, for 1988-1990) from the Statistical Yearbook series, but these are pre-tertiary sector census data. GDP 1952-95 has provincial values for other years, but since the compilation of NIPA data following the SNA only began in the second half of the 1980s, the comparison of national and summed provincial data would have had to be based on retrospectively compiled values.

Sources: post-economic census national values: Statistical Yearbook 2006, pp. 57, 63f.; pre-economic census national values: Statistical Yearbook 2005, p. 51; pre-economic census provincial values: each year's issue of the Statistical Yearbook (prior to the 2006 benchmark revision, provincial values were never revised in the Statistical Yearbook, except that the 1993 provincial values incorporate the 1995 benchmark revision following the 1993 tertiary sector census). 


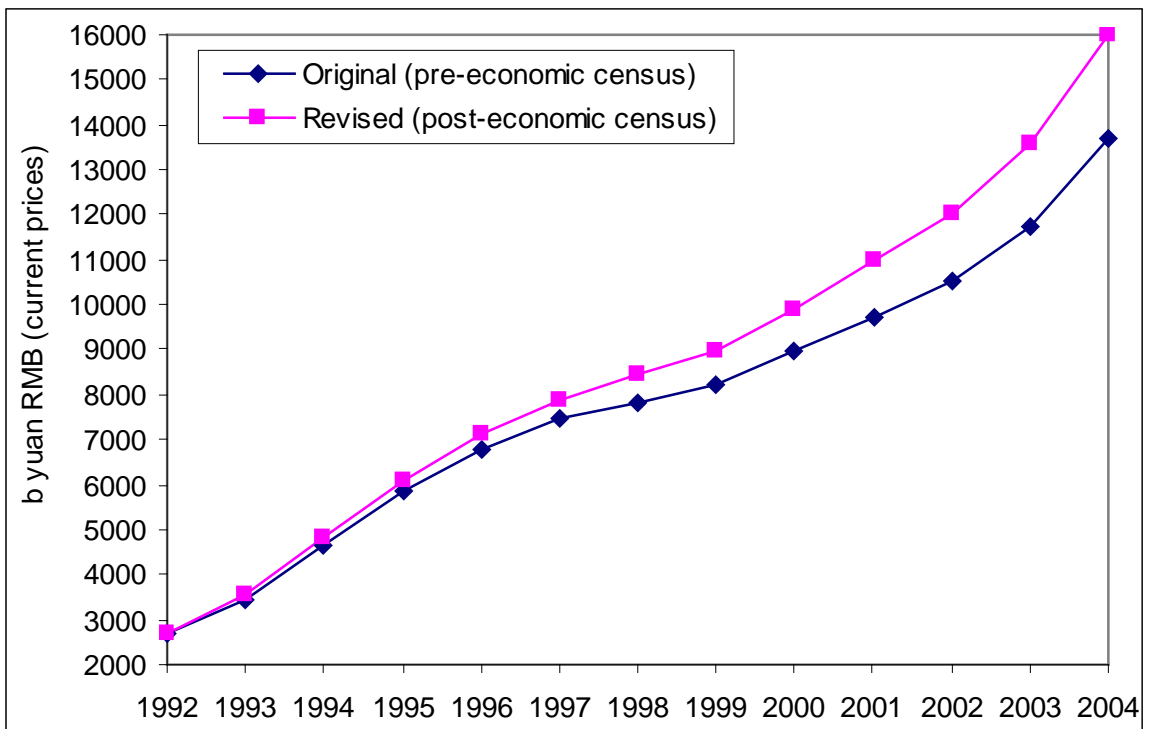

Sources: pre-economic census values from Statistical Yearbook 2005, p. 51, post-economic census values (for 1993-2004) from Economic Census 2004 (9 Jan. 2006).

Figure 2. Pre- and Post-Economic Census 2004 GDP, 1992-2004 
Table 7. Ratio of Post- to Pre-Economic Census Expenditure Values

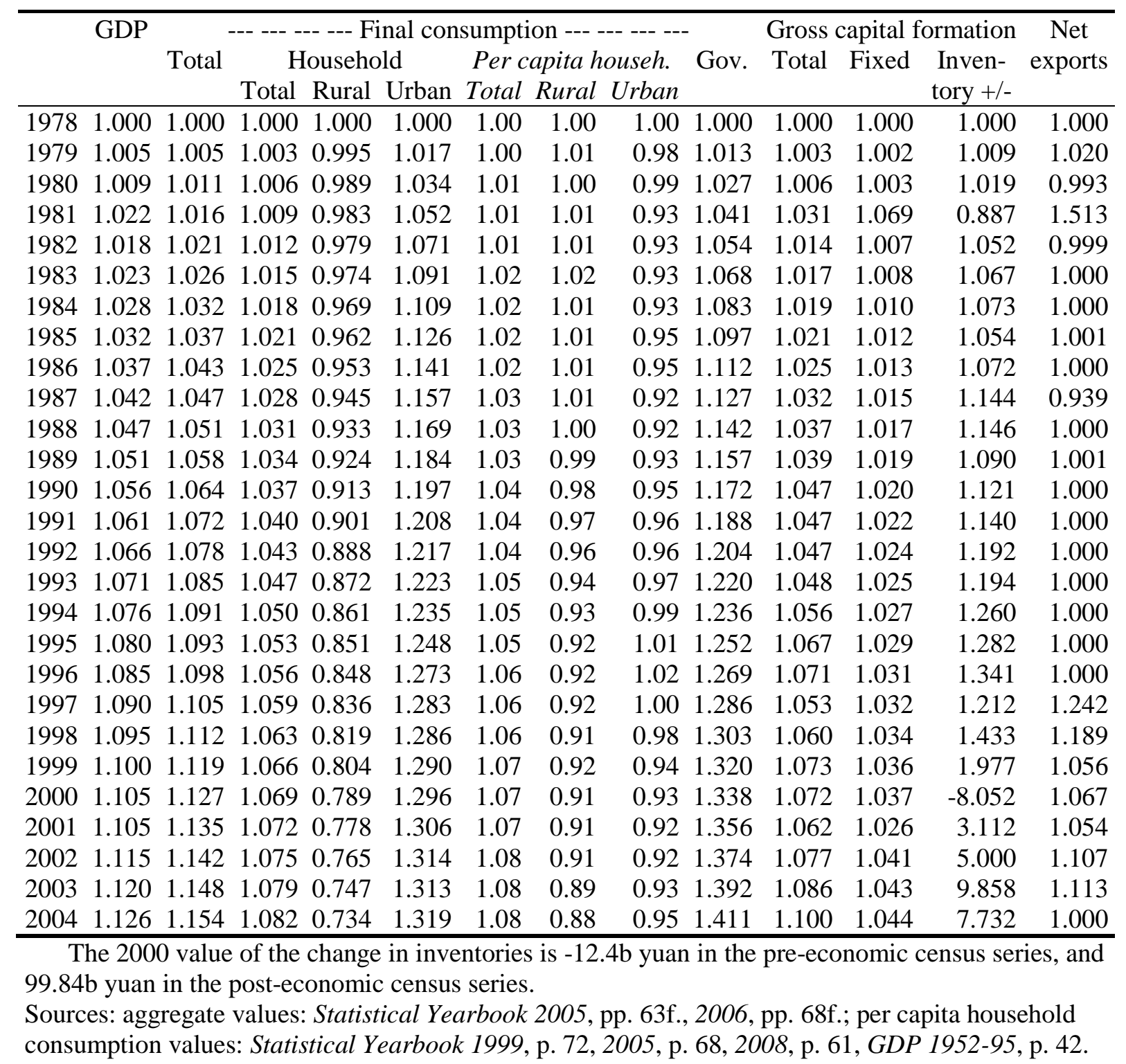




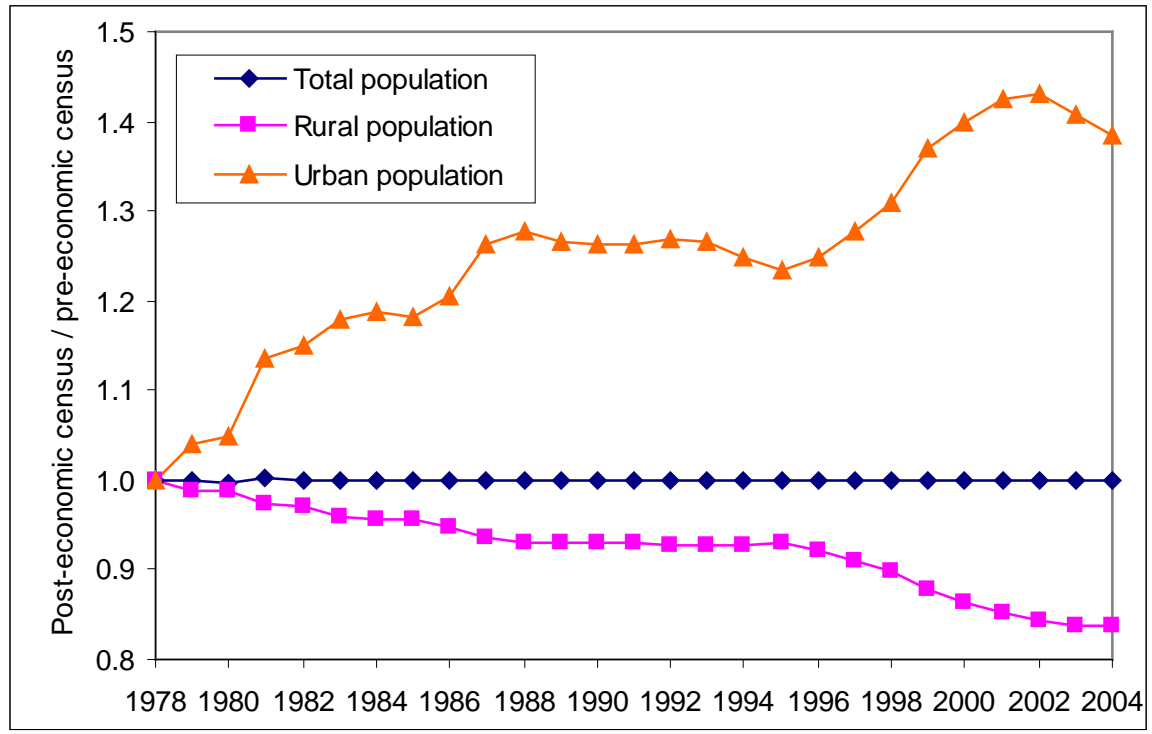

Sources: for aggregate (nominal) values see sources to Table 7; per capita (nominal) values: Statistical Yearbook 2001, p. 66; 2003, p. 72; 2005, p. 68; 2006, p. 73.

Figure 3. Ratio of Post- to Pre-Economic Census Population Numbers Implicit in Aggregate and Per Capita Household Consumption Values 
Table 8. Real Growth Rates and Implicit Deflators of Expenditures, Post- Vs. PreEconomic Census

\begin{tabular}{|c|c|c|c|c|c|c|c|c|c|c|c|}
\hline & \multicolumn{8}{|c|}{ Final consumption } & \multicolumn{3}{|c|}{ Gross capital formation } \\
\hline & Total & $\begin{array}{l}\text { House- } \\
\text { hold }\end{array}$ & \# Rural & \# Urban & \multicolumn{3}{|c|}{$\begin{array}{l}\text { Per capita househ. } \\
\text { All Rural Urban }\end{array}$} & $\begin{array}{c}\text { Govern- } \\
\text { ment }\end{array}$ & Total & Fixed & $\begin{array}{l}\text { Inven- } \\
\text { tory +/- }\end{array}$ \\
\hline \multicolumn{12}{|c|}{ A. Post-economic census minus pre-economic census real growth rates (percentage point difference) } \\
\hline 1979 & 0.6 & 0.3 & -0.6 & 1.8 & 0.4 & 0.4 & -2.4 & 1.7 & 0.3 & 0.2 & 0.7 \\
\hline 1980 & 0.6 & 0.3 & -0.7 & 1.9 & 0.3 & -0.4 & 0.9 & 1.4 & 0.3 & 0.1 & 0.7 \\
\hline 1981 & 0.6 & 0.3 & -0.6 & 1.8 & 0.3 & 1.4 & -6.6 & 1.4 & 2.4 & 6.0 & -15.4 \\
\hline 1982 & 0.6 & 0.3 & -0.6 & 1.9 & 0.3 & 0.0 & 0.3 & 1.5 & -1.9 & -6.8 & 14.1 \\
\hline 1983 & 0.6 & 0.3 & -0.5 & 2.0 & 0.3 & 0.2 & -0.4 & 1.5 & 0.2 & 0.2 & 0.8 \\
\hline 1984 & 0.7 & 0.4 & -0.6 & 2.0 & 0.4 & -0.1 & 0.9 & 1.6 & 0.0 & 0.2 & -0.5 \\
\hline 1985 & 0.6 & 0.3 & -0.9 & 2.3 & 0.4 & -0.8 & 2.9 & 1.5 & -0.1 & 0.2 & -4.8 \\
\hline 1986 & 0.6 & 0.3 & -1.0 & 1.7 & 0.3 & -0.2 & -0.6 & 1.5 & 0.5 & 0.1 & 1.4 \\
\hline 1987 & 0.6 & 0.4 & -1.0 & 1.9 & 0.4 & 0.6 & -3.1 & 1.5 & 0.6 & 0.2 & 3.1 \\
\hline 1988 & 0.5 & 0.3 & -1.3 & 2.0 & 0.4 & -0.8 & 0.8 & 1.4 & 0.7 & 0.1 & 2.4 \\
\hline 1989 & 0.7 & 0.3 & -1.0 & 1.7 & 0.3 & -0.9 & 2.3 & 1.4 & 0.4 & 0.1 & -4.2 \\
\hline 1990 & 0.7 & 0.4 & -1.1 & 0.9 & 0.3 & -1.1 & 1.0 & 1.4 & 0.7 & 0.2 & 2.4 \\
\hline 1991 & 0.8 & 0.3 & -1.4 & 1.4 & 0.3 & -1.3 & 1.4 & 1.6 & 0.1 & 0.2 & 1.9 \\
\hline 1992 & 0.6 & 0.4 & -1.6 & 1.0 & 0.4 & -1.3 & 0.7 & 1.5 & 0.1 & 0.2 & 4.2 \\
\hline 1993 & 0.6 & 0.3 & -1.9 & 1.3 & 0.3 & -1.8 & 1.5 & 1.4 & -0.2 & 0.2 & -2.5 \\
\hline 1994 & 0.6 & 0.3 & -1.3 & 1.3 & 0.3 & -1.5 & 2.7 & 1.4 & 1.2 & 0.2 & 8.0 \\
\hline 1995 & 0.5 & 0.3 & -1.3 & 1.5 & 0.3 & -1.4 & 2.6 & 1.4 & 0.6 & 0.2 & 0.4 \\
\hline 1996 & 0.6 & 0.3 & -0.3 & 2.3 & 0.3 & 0.5 & 0.9 & 1.5 & 0.5 & 0.2 & 4.8 \\
\hline 1997 & 0.7 & 0.4 & -1.5 & 1.0 & 0.3 & -0.2 & -1.3 & 1.4 & -0.2 & 0.2 & 0.7 \\
\hline 1998 & 0.6 & 0.3 & -1.7 & -0.1 & 0.4 & -0.6 & -2.4 & 1.4 & -1.3 & -2.0 & 19.4 \\
\hline 1999 & 0.6 & 0.3 & -2.0 & 0.6 & 0.4 & 0.4 & -4.3 & 1.4 & 1.8 & 2.3 & 12.7 \\
\hline 2000 & 0.6 & 0.3 & -1.9 & 0.1 & 0.3 & -0.3 & -2.3 & 1.5 & 0.3 & 0.2 & n.a. \\
\hline 2001 & 0.8 & 0.3 & -1.5 & 0.7 & 0.4 & 0.0 & -1.2 & 1.5 & -1.0 & -1.3 & n.a. \\
\hline 2002 & 1.5 & 1.1 & -0.4 & 1.1 & 0.3 & -0.5 & 0.2 & 2.8 & 1.5 & 1.0 & n.a. \\
\hline 2003 & & & & & 0.2 & -2.4 & 1.4 & & & & \\
\hline 2004 & & & & & 0.2 & -1.3 & 1.4 & & & & \\
\hline 02/78 & 0.7 & 0.4 & -1.1 & 1.4 & 0.3 & -0.4 & -0.2 & 1.5 & 0.3 & 0.2 & n.a. \\
\hline $04 / 78$ & & & & & 0.3 & -0.5 & -0.1 & & & & \\
\hline \multicolumn{12}{|c|}{ B. Post-economic census minus pre-economic census implicit deflators (percentage point difference) } \\
\hline 1979 & 0.0 & 0.0 & 0.0 & 0.1 & 0.1 & 0.3 & 0.2 & 0.0 & 0.0 & 0.0 & 0.2 \\
\hline 1980 & 0.0 & 0.0 & 0.0 & -0.1 & 0.1 & -0.3 & -0.2 & 0.0 & 0.0 & 0.0 & 0.2 \\
\hline 1981 & 0.0 & 0.0 & 0.0 & 0.1 & -0.4 & -0.3 & 0.0 & 0.0 & 0.0 & 0.0 & -0.2 \\
\hline 1982 & -0.1 & 0.0 & 0.1 & 0.0 & 0.4 & -0.1 & 0.1 & 0.0 & 0.1 & 0.0 & 0.9 \\
\hline 1983 & 0.0 & 0.0 & 0.0 & -0.1 & -0.1 & 0.5 & -0.2 & -0.1 & 0.1 & 0.0 & 0.6 \\
\hline 1984 & 0.0 & -0.1 & 0.0 & -0.1 & 0.0 & -0.1 & 0.0 & 0.0 & 0.2 & 0.0 & 1.1 \\
\hline 1985 & -0.1 & 0.0 & 0.0 & -0.5 & -0.3 & -0.1 & -0.5 & 0.0 & 0.4 & 0.0 & 0.7 \\
\hline 1986 & 0.0 & 0.0 & 0.1 & -0.2 & 0.1 & 0.2 & -0.1 & 0.0 & -0.1 & 0.1 & 0.2 \\
\hline 1987 & -0.1 & -0.1 & 0.0 & -0.4 & -0.1 & -0.2 & -0.5 & -0.1 & 0.2 & 0.0 & 2.5 \\
\hline 1988 & -0.1 & 0.0 & 0.0 & -0.9 & -0.1 & 0.0 & -0.9 & 0.0 & -0.1 & 0.0 & -1.8 \\
\hline 1989 & -0.1 & 0.0 & 0.0 & -0.4 & 0.1 & 0.0 & -0.3 & 0.0 & -0.3 & 0.0 & -3.0 \\
\hline 1990 & -0.1 & -0.1 & -0.1 & 0.3 & 0.0 & -0.1 & 0.3 & 0.1 & 0.1 & 0.0 & 0.3 \\
\hline 1991 & 0.1 & 0.0 & 0.0 & -0.3 & 0.0 & 0.1 & -0.3 & 0.0 & -0.2 & 0.0 & -0.5 \\
\hline 1992 & 0.1 & -0.1 & 0.0 & -0.1 & -0.1 & 0.0 & -0.2 & 0.0 & -0.1 & 0.0 & -1.3 \\
\hline
\end{tabular}




\begin{tabular}{rrrrrrrrrrrr}
1993 & 0.1 & 0.0 & 0.0 & -0.8 & 0.1 & -0.1 & -0.9 & 0.1 & 0.3 & 0.0 & 2.6 \\
1994 & 0.0 & 0.0 & 0.0 & -0.3 & 0.0 & 0.1 & -0.2 & 0.1 & -0.3 & 0.0 & -2.4 \\
1995 & -0.4 & 0.0 & 0.0 & -0.3 & 0.1 & -0.1 & -0.3 & 0.0 & 0.5 & 0.0 & 1.7 \\
1996 & -0.1 & 0.0 & -0.1 & -0.2 & 0.0 & 0.0 & -0.2 & 0.0 & 0.0 & 0.0 & -0.5 \\
1997 & 0.0 & -0.1 & 0.0 & -0.1 & 0.0 & 0.0 & -0.1 & 0.0 & -1.5 & 0.0 & -10.3 \\
1998 & 0.1 & 0.0 & -0.4 & 0.3 & 0.0 & 0.0 & 0.0 & 0.0 & 1.8 & 1.9 & -13.3 \\
1999 & 0.1 & 0.0 & 0.0 & -0.2 & -0.1 & 0.0 & -0.2 & 0.0 & -0.5 & -2.0 & 15.1 \\
2000 & 0.1 & 0.0 & 0.0 & 0.3 & 0.0 & -0.1 & 0.3 & 0.0 & -0.4 & 0.0 & n.a. \\
2001 & 0.0 & 0.0 & 0.0 & 0.1 & -0.1 & 0.0 & 0.2 & 0.0 & -0.1 & 0.0 & n.a. \\
2002 & -0.1 & 0.0 & -0.8 & 0.6 & 0.0 & 0.0 & 0.0 & -0.7 & 0.0 & 0.0 & n.a. \\
2003 & & & & & 0.1 & 0.4 & 0.2 & & & & \\
2004 & & & & & 0.1 & -0.4 & 0.9 & & & & \\
$02 / 78$ & 0.0 & 0.0 & -0.1 & -0.1 & 0.0 & 0.0 & -0.2 & 0.0 & 0.0 & 0.0 & n.a. \\
$04 / 78$ & & & & & 0.0 & 0.0 & -0.1 & & & & \\
\hline
\end{tabular}

02/78 (04/78): difference over these years between (geometric) average annual post-economic census real growth rate or deflator (inflation) rate and the corresponding pre-economic census value.

Sources: pre-economic census aggregate data: GDP 1996-2002, pp. 22, 25, 27, 29 (and Statistical Yearbook 2005, pp. 63, 64, for nominal values of 1978-1980, 1982-1985, and 1987-1988); post-economic census aggregate data: GDP 1952-2004, pp. 20, 23, 25, 27; pre-economic census per capita data: Statistical Yearbook 1999, p. 72, 2005, p. 68, GDP 1952-95, pp. 42, 46, 48; post-economic census per capita data: Statistical Yearbook 2008, p. 61. 
Table 9. Real Growth Rates and Implicit Deflators of Aggregate Vs. Per Capita Household Consumption

\begin{tabular}{|c|c|c|c|c|c|c|c|c|c|c|c|c|}
\hline & \multicolumn{6}{|c|}{ Aggregate minus per capita real growth rates } & \multicolumn{6}{|c|}{ Aggregate minus per capita implicit deflators } \\
\hline & \multicolumn{3}{|c|}{ Pre-economic census } & \multicolumn{3}{|c|}{ Post-economic census } & \multicolumn{3}{|c|}{ Pre-economic census } & \multicolumn{3}{|c|}{ Post-economic census } \\
\hline & All & Rural & Urban & All & Rural & Urban & All & Rural & Urban & All & Rural & Urban \\
\hline 1979 & 1.5 & 0.8 & 4.6 & 1.4 & -0.2 & 8.8 & -0.1 & 0.0 & 0.0 & -0.2 & -0.3 & -0.1 \\
\hline 1980 & 1.4 & 0.7 & 4.7 & 1.4 & 0.4 & 5.7 & 0.1 & -0.1 & 0.0 & 0.0 & 0.2 & 0.1 \\
\hline 1981 & 1.4 & 2.6 & -3.8 & 1.4 & 0.6 & 4.6 & -0.1 & -0.2 & 0.0 & 0.3 & 0.1 & 0.1 \\
\hline 1982 & 1.6 & 1.0 & 4.4 & 1.6 & 0.4 & 6.0 & 0.1 & -0.1 & 0.0 & -0.2 & 0.1 & -0.1 \\
\hline 1983 & 1.6 & 1.3 & 2.8 & 1.6 & 0.6 & 5.2 & -0.1 & 0.3 & -0.1 & 0.0 & -0.2 & 0.0 \\
\hline 1984 & 1.5 & 0.6 & 5.2 & 1.5 & 0.1 & 6.3 & 0.1 & 0.0 & 0.0 & 0.0 & 0.1 & -0.1 \\
\hline 1985 & 1.6 & 0.1 & 7.4 & 1.5 & 0.0 & 6.8 & -0.3 & -0.2 & 0.0 & 0.1 & -0.1 & 0.0 \\
\hline 1986 & 1.6 & 1.3 & 2.8 & 1.6 & 0.5 & 5.1 & 0.1 & 0.1 & 0.1 & 0.0 & 0.0 & 0.0 \\
\hline 1987 & 1.7 & 2.1 & 0.3 & 1.7 & 0.5 & 5.3 & 0.0 & 0.0 & -0.1 & 0.0 & 0.1 & 0.1 \\
\hline 1988 & 1.8 & 1.3 & 3.4 & 1.7 & 0.8 & 4.6 & -0.1 & -0.1 & 0.0 & 0.0 & -0.1 & 0.1 \\
\hline 1989 & 1.5 & 1.0 & 4.0 & 1.5 & 0.9 & 3.4 & 0.1 & 0.0 & 0.0 & 0.0 & 0.0 & -0.1 \\
\hline 1990 & 1.5 & 1.1 & 3.0 & 1.6 & 1.1 & 2.9 & 0.0 & -0.1 & 0.0 & -0.1 & -0.1 & 0.0 \\
\hline 1991 & 1.5 & 1.1 & 3.1 & 1.5 & 1.0 & 3.1 & 0.1 & 0.1 & 0.0 & 0.1 & 0.0 & 0.0 \\
\hline 1992 & 1.4 & 0.9 & 3.4 & 1.4 & 0.6 & 3.7 & -0.1 & 0.0 & -0.1 & -0.1 & -0.1 & 0.0 \\
\hline 1993 & 1.3 & 0.6 & 3.6 & 1.3 & 0.5 & 3.4 & 0.0 & 0.0 & 0.0 & -0.1 & 0.0 & 0.1 \\
\hline 1994 & 1.2 & 0.2 & 4.6 & 1.2 & 0.4 & 3.2 & 0.0 & 0.0 & 0.0 & 0.0 & 0.0 & 0.0 \\
\hline 1995 & 1.2 & 0.2 & 4.3 & 1.2 & 0.3 & 3.2 & 0.0 & 0.0 & 0.0 & 0.0 & 0.2 & 0.0 \\
\hline 1996 & 1.2 & 0.4 & 3.3 & 1.2 & -0.4 & 4.7 & -0.1 & 0.1 & 0.0 & 0.0 & 0.0 & 0.0 \\
\hline 1997 & 1.0 & 0.3 & 3.7 & 1.1 & -1.0 & 6.0 & 0.1 & -0.1 & 0.0 & 0.0 & -0.1 & 0.0 \\
\hline 1998 & 1.1 & 0.0 & 3.6 & 1.0 & -1.1 & 5.9 & 0.0 & 0.3 & -0.3 & 0.0 & -0.1 & 0.0 \\
\hline 1999 & 1.0 & 1.1 & 0.8 & 0.9 & -1.3 & 5.7 & 0.0 & 0.0 & -0.1 & 0.1 & 0.0 & 0.0 \\
\hline 2000 & 0.8 & 0.1 & 3.0 & 0.8 & -1.5 & 5.4 & 0.0 & 0.0 & 0.0 & 0.0 & 0.1 & 0.0 \\
\hline 2001 & 0.8 & -0.1 & 3.1 & 0.7 & -1.6 & 5.0 & 0.0 & 0.0 & 0.0 & 0.1 & 0.0 & 0.0 \\
\hline 2002 & -0.1 & -1.8 & 3.9 & 0.7 & -1.7 & 4.8 & 0.0 & 0.8 & -0.6 & 0.0 & 0.0 & 0.0 \\
\hline 2003 & & & & 0.7 & -1.7 & 4.7 & & & & 0.0 & -0.1 & 0.0 \\
\hline 2004 & & & & 0.7 & -1.7 & 4.2 & & & & -0.1 & 0.0 & 0.0 \\
\hline 78-02 & 1.3 & 0.7 & 3.3 & 1.3 & 0.0 & 5.0 & 0.0 & 0.0 & 0.0 & 0.0 & 0.0 & 0.0 \\
\hline 78-04 & & & & 1.3 & -0.1 & 4.9 & & & & 0.0 & 0.0 & 0.0 \\
\hline
\end{tabular}

All = all households.

78-02 (78-04): arithmetic mean of the annual real growth rates or deflators between 1978 and 2002 (2004).

Sources: aggregate data: pre-economic census data: GDP 1996-2002, pp. 22, 25, 27, 29 (and Statistical Yearbook 2005, pp. 63,64, for nominal values of 1978-1980, 1982-1985, and 1987-1988); post-economic census data: GDP 1952-2004, pp. 20, 23, 25, 27; per capita data: pre-economic census data: Statistical Yearbook 1999, p. 72, 2005, p. 68, GDP 1952-95, pp. 42, 46, 48; post-economic census data: Statistical Yearbook 2008, p. 61. 


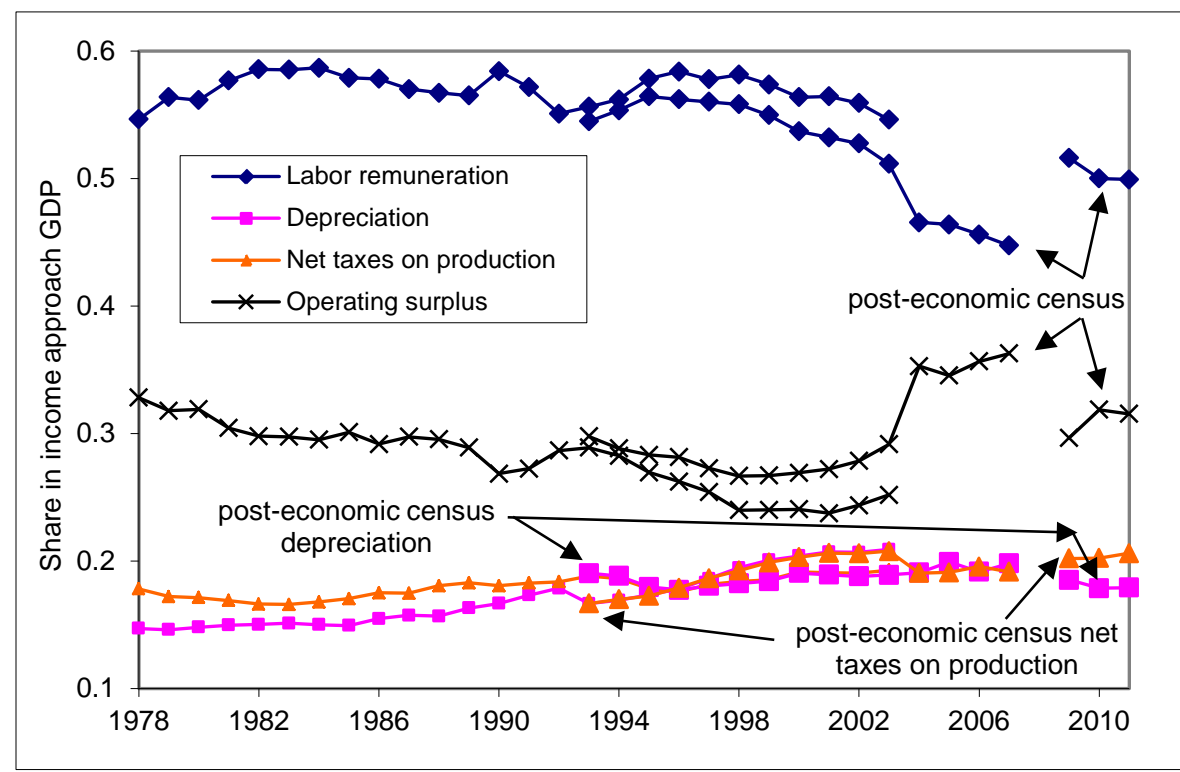

All data are summed provincial (nominal) data. National values have never been released.

1978-2003 values are pre-economic census values; these have not been revised. 1993-2011 values are post-economic census values; 2008 values are not available.

Markers for pre-economic census net taxes on production and operating surplus are reduced in size (those for post-economic census values are of regular size). Pre-economic census values of each of these two series after 1993 are not/barely discernible in the figure as they are covered by the post-economic census values of the opposite series.

Sources: pre-economic census values: 1978-1995: GDP 1952-95; 1996-2005: individual issues of the Statistical Yearbook 1997 through 2004; post-economic census values: GDP 1952-2004, pp. 63-8; Statistical Yearbook 2006, p. 67; 2007, p. 71, 2008, p. 53; 2010, p. 54; 2011, p. 60; 2012, p. 60.

\section{Figure 4. Shares of Individual Components in Income Approach GDP}


Table 10. Post- Vs. Pre-Economic Census Income Values, National and Selected Provinces, 1993 and 2002

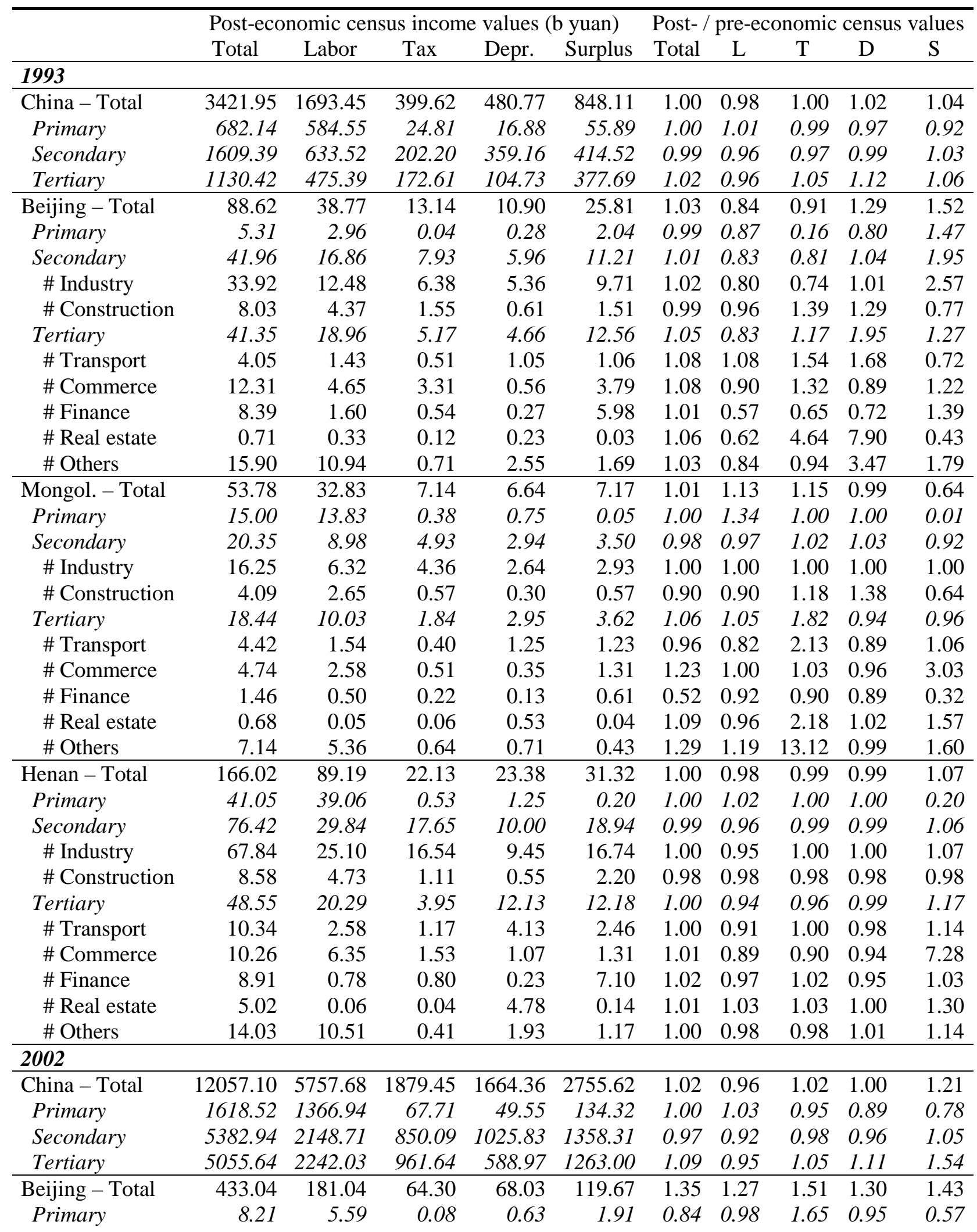




\begin{tabular}{|c|c|c|c|c|c|c|c|c|c|c|}
\hline Secondary & 125.00 & 52.43 & 25.02 & 19.89 & 27.66 & 1.12 & 1.03 & 1.15 & 1.08 & 1.33 \\
\hline \# Industry & 102.12 & 39.33 & 20.02 & 17.92 & 24.85 & 1.17 & 1.09 & 1.17 & 1.09 & 1.39 \\
\hline \# Construction & 22.88 & 13.10 & 5.00 & 1.97 & 2.81 & 0.94 & 0.90 & 1.07 & 0.98 & 0.96 \\
\hline Tertiary & 299.83 & 123.02 & 39.20 & 47.50 & 90.11 & 1.50 & 1.42 & 1.88 & 1.42 & 1.52 \\
\hline \# Transport & 40.84 & 8.13 & 3.29 & 13.36 & 16.06 & 1.70 & 1.67 & 2.23 & 1.79 & 1.57 \\
\hline \# Commerce & 50.97 & 19.69 & 15.22 & 2.94 & 13.12 & 1.04 & 1.77 & 8.19 & 1.21 & 0.39 \\
\hline \# Finance & 56.19 & 11.56 & 4.82 & 3.09 & 36.73 & 4.52 & 1.70 & 1.20 & 1.27 & -44.52 \\
\hline \# Real estate & 29.80 & 5.86 & 6.12 & 9.58 & 8.24 & 1.41 & 1.19 & 1.19 & 1.36 & 2.08 \\
\hline \# Others & 122.03 & 77.79 & 9.74 & 18.54 & 15.95 & 1.31 & 1.33 & 1.17 & 1.33 & 1.30 \\
\hline Mongolia - Total & 194.09 & 91.41 & 21.07 & 27.61 & 54.00 & 1.12 & 0.84 & 1.37 & 1.16 & 2.08 \\
\hline Primary & 37.47 & 33.48 & 1.18 & 2.70 & 0.11 & 1.00 & 1.25 & 1.00 & 1.00 & 0.02 \\
\hline Secondary & 75.48 & 32.98 & 12.07 & 13.00 & 17.44 & 1.04 & 0.93 & 1.30 & 1.12 & 1.05 \\
\hline \# Industry & 61.49 & 25.30 & 10.13 & 12.24 & 13.82 & 1.07 & 1.04 & 1.41 & 1.18 & 0.89 \\
\hline \# Construction & 13.99 & 7.68 & 1.94 & 0.75 & 3.62 & 0.90 & 0.70 & 0.93 & 0.61 & 3.02 \\
\hline Tertiary & 81.15 & 24.95 & 7.83 & 11.92 & 36.46 & 1.29 & 0.54 & 1.58 & 1.25 & 14.16 \\
\hline \# Transport & 24.43 & 5.39 & 2.20 & 4.36 & 12.49 & 1.30 & 0.44 & 1.42 & 1.11 & 10.58 \\
\hline \# Commerce & 26.65 & 4.98 & 2.64 & 1.26 & 17.78 & 1.62 & 0.41 & 1.63 & 1.05 & 11.74 \\
\hline \# Finance & 4.40 & 1.36 & 0.67 & 0.28 & 2.09 & 1.65 & 0.65 & 0.91 & 0.77 & -3.88 \\
\hline \# Real estate & 5.15 & 0.38 & 0.46 & 4.00 & 0.30 & 2.26 & 0.90 & 3.57 & 2.40 & 5.97 \\
\hline \# Others & 20.52 & 12.84 & 1.85 & 2.03 & 3.81 & 0.89 & 0.66 & 2.08 & 0.86 & 10.34 \\
\hline Henan - Total & 603.55 & 282.86 & 70.96 & 79.16 & 170.57 & 0.98 & 0.76 & 0.92 & 0.92 & 2.10 \\
\hline Primary & 128.84 & 121.92 & 2.59 & 4.09 & 0.23 & 1.00 & 1.07 & 1.06 & 1.03 & 0.03 \\
\hline Secondary & 276.88 & 89.39 & 52.02 & 35.31 & 100.16 & 0.94 & 0.64 & 0.94 & 0.95 & 1.59 \\
\hline \# Industry & 241.22 & 71.94 & 47.70 & 32.96 & 88.62 & 0.95 & 0.60 & 0.95 & 0.96 & 1.80 \\
\hline \# Construction & 35.66 & 17.45 & 4.32 & 2.35 & 11.54 & 0.85 & 0.85 & 0.85 & 0.85 & 0.85 \\
\hline Tertiary & 197.84 & 71.55 & 16.35 & 39.75 & 70.18 & 1.03 & 0.60 & 0.86 & 0.88 & 7.17 \\
\hline \# Transport & 47.08 & 11.08 & 4.61 & 10.50 & 20.89 & 0.96 & 0.40 & 0.96 & 0.80 & 6.31 \\
\hline \# Commerce & 51.40 & 10.65 & 5.73 & 3.64 & 31.38 & 1.10 & 0.34 & 0.70 & 0.60 & 20.98 \\
\hline \# Finance & 15.88 & 5.99 & 2.66 & 0.83 & 6.39 & 1.20 & 0.71 & 1.20 & 0.58 & 5.61 \\
\hline \# Real estate & 19.93 & 0.81 & 0.86 & 17.51 & 0.76 & 1.07 & 1.49 & 1.29 & 1.00 & -4.87 \\
\hline \# Others & 63.55 & 43.02 & 2.49 & 7.27 & 10.76 & 0.97 & 0.84 & 0.77 & 1.07 & 2.69 \\
\hline
\end{tabular}

Labor (or “L”): Labor remuneration, Tax (or “T”): Net taxes on production; Depr. (or “D”):

Depreciation, Surplus (or “S”): Operating surplus. China-Total: summed provincial values.

Primary (sector), Secondary (sector), Tertiary (sector); Transport: Transport, storage and post, telecommunications; Commerce: Wholesale, retail trade and catering services; Finance: Finance and insurance; Others: residual within tertiary sector. Mongol.: Inner Mongolia.

Sources: provincial data: 1993 pre-economic census values: GDP 1952-95, pp. 107f., 247f., 632f.; 2002 pre-economic census values: GDP 1996-2002, pp. 137-40, 197-200, 362-5; 1993 and 2002 post-economic census values: GDP 1952-2004, pp. 124-6, 164-6, 274-6; national data (as summed provincial values): 1993 pre-economic census values from GDP 1952-95 (individual provincial pages), 2002 pre-economic census values from GDP 1996-2002, pp. 72, 78, 84, 90; post-economic census values for 1993 and 2002 from GDP 1952-2004, pp. 67, 73, 79, 85. 
Table 11. Pre- and Post-Economic Census 2008 Value-Added

\begin{tabular}{|c|c|c|c|c|c|c|}
\hline & GDP & $\begin{array}{l}\text { Primary } \\
\text { sector }\end{array}$ & $\begin{array}{l}\text { Secondary } \\
\text { sector }\end{array}$ & $\begin{array}{c}\# \\
\text { Industry }\end{array}$ & $\begin{array}{c}\# \\
\text { Construction }\end{array}$ & $\begin{array}{l}\text { Tertiary } \\
\text { sector }\end{array}$ \\
\hline \multicolumn{7}{|c|}{ A. Post-economic census national vs. pre-economic census national values, percentage difference } \\
\hline 2004 & 0.0 & 0.0 & 0.0 & 0.0 & 0.0 & 0.0 \\
\hline 2005 & 0.9 & 0.0 & 0.3 & 0.0 & 2.3 & 2.0 \\
\hline 2006 & 2.1 & 0.0 & 0.5 & 0.0 & 4.7 & 4.5 \\
\hline 2007 & 3.3 & 0.0 & 0.8 & 0.0 & 7.2 & 7.2 \\
\hline 2008 & 4.4 & -0.9 & 1.9 & 0.9 & 9.8 & 9.0 \\
\hline \multicolumn{7}{|c|}{$\begin{array}{l}\text { B. Summed provincial pre-economic census vs. national pre-economic census values, percentage } \\
\text { difference }\end{array}$} \\
\hline 2004 & 2.1 & -2.4 & 11.6 & 8.6 & 33.5 & -7.2 \\
\hline 2005 & 8.0 & 2.6 & 10.9 & 10.6 & 13.5 & 6.0 \\
\hline 2006 & 9.0 & 2.9 & 12.1 & 12.3 & 10.3 & 7.0 \\
\hline 2007 & 7.1 & -0.2 & 10.8 & 11.6 & 5.1 & 4.7 \\
\hline 2008 & 8.8 & -0.7 & 14.2 & 15.4 & 4.8 & 5.1 \\
\hline \multicolumn{7}{|c|}{$\begin{array}{l}\text { C. Summed provincial pre-economic census vs. national post-economic census values, percentage } \\
\text { difference }\end{array}$} \\
\hline 2004 & 2.1 & -2.4 & 11.6 & 8.6 & 33.5 & -7.2 \\
\hline 2005 & 6.9 & 2.6 & 10.6 & 10.6 & 10.9 & 3.9 \\
\hline 2006 & 6.8 & 2.9 & 11.5 & 12.3 & 5.3 & 2.4 \\
\hline 2007 & 3.7 & -0.2 & 9.9 & 11.6 & -2.0 & -2.4 \\
\hline 2008 & 4.2 & 0.1 & 12.0 & 14.4 & -4.5 & -3.6 \\
\hline \multirow{2}{*}{\multicolumn{7}{|c|}{$\begin{array}{l}\text { D. Summed provincial post-economic census vs. national post-economic census values, percentage } \\
\text { difference } \\
2004\end{array}$}} \\
\hline & & & & & & \\
\hline 2005 & 7.7 & & & & & \\
\hline 2006 & 7.6 & & & & & \\
\hline 2007 & 5.2 & & & & & \\
\hline 2008 & 6.1 & & & & & \\
\hline \multicolumn{7}{|c|}{ E. Post-economic census less pre-economic census real growth rates, percentage points } \\
\hline 2004 & 0.0 & 0.0 & 0.0 & 0.0 & 0.0 & 0.0 \\
\hline 2005 & 0.9 & 0.0 & 0.4 & 0.0 & 3.4 & 1.7 \\
\hline 2006 & 1.1 & 0.0 & 0.4 & 0.0 & 3.5 & 2.0 \\
\hline 2007 & 1.2 & 0.0 & 0.4 & 0.0 & 3.4 & 2.2 \\
\hline 2008 & 0.6 & -0.1 & 0.6 & 0.4 & 2.4 & 0.9 \\
\hline \multicolumn{7}{|c|}{ F. Post-economic census less pre-economic census implicit deflators, percentage points } \\
\hline 2004 & 0.0 & 0.0 & 0.0 & 0.0 & 0.0 & 0.0 \\
\hline 2005 & 0.1 & 0.0 & -0.1 & 0.0 & -0.7 & 0.5 \\
\hline 2006 & 0.1 & 0.0 & -0.1 & 0.0 & -0.7 & 0.7 \\
\hline 2007 & 0.2 & 0.0 & -0.1 & 0.0 & -0.6 & 0.7 \\
\hline 2008 & 0.6 & -0.9 & 0.6 & 0.6 & 0.2 & 0.9 \\
\hline
\end{tabular}

Percentage difference is as percentage of the second variable.

Sources: Pre-economic (post-economic) census 2008 national values are from the Statistical Yearbook 2009 (2012). Pre-economic (post-economic) census 2008 provincial values are from the Statistical Yearbook 2009 and earlier issues (Statistical Yearbook 2010). 
Table 12. Post- versus Pre-Economic Census 2008 Expenditures (percentage difference)

\begin{tabular}{|c|c|c|c|c|c|c|c|c|c|c|}
\hline & GDP & $\begin{array}{l}\text { Final } \\
\text { con- } \\
\text { sumption }\end{array}$ & $\begin{array}{l}\text { \# House- } \\
\text { hold }\end{array}$ & $\begin{array}{l}\text { \#\# } \\
\text { Rural } \\
\end{array}$ & $\begin{array}{l}\# \# \\
\text { Urban }\end{array}$ & $\begin{array}{l}\text { \# Govern- } \\
\text { ment }\end{array}$ & $\begin{array}{l}\text { Gross } \\
\text { capital } \\
\text { formation }\end{array}$ & \# GFCF & $\begin{array}{l}\text { \# Inven- } \\
\text { tory +/- }\end{array}$ & $\begin{array}{l}\text { Net } \\
\text { exports }\end{array}$ \\
\hline 2000 & 0.0 & 0.0 & 0.0 & 0.0 & 0.0 & 0.0 & 0.0 & 0.0 & 0.0 & 0.0 \\
\hline 2001 & 0.1 & 0.1 & 0.5 & 0.0 & 0.7 & -0.9 & 0.0 & 0.0 & 0.0 & 0.0 \\
\hline 2002 & 0.1 & 0.2 & 0.9 & 0.0 & 1.3 & -1.9 & 0.0 & 0.0 & 0.0 & 0.0 \\
\hline 2003 & 0.2 & 0.3 & 1.4 & 0.0 & 2.0 & -2.8 & 0.0 & 0.0 & 0.0 & -0.7 \\
\hline 2004 & 0.4 & 0.6 & 2.2 & 0.8 & 2.7 & -3.7 & 0.0 & 0.0 & 0.0 & 3.8 \\
\hline 2005 & -0.7 & 1.6 & 2.4 & 3.8 & 1.9 & -0.8 & -3.5 & -4.0 & 8.5 & -0.1 \\
\hline 2006 & 0.5 & 2.3 & 2.6 & 3.2 & 2.4 & 1.4 & -1.5 & -2.4 & 17.6 & 0.0 \\
\hline 2007 & 1.3 & 2.7 & 2.9 & 1.2 & 3.5 & 2.0 & 0.0 & -1.4 & 27.6 & 0.2 \\
\hline 2008 & 3.0 & 2.9 & 3.0 & 1.7 & 3.5 & 2.5 & 3.5 & 1.5 & 38.3 & 0.4 \\
\hline
\end{tabular}

Percentage difference of values reported in the Statistical Yearbook 2012 compared to the Statistical

Yearbook 2009. GFCF: gross fixed capital formation.. 
Table 13. Official GDP Real Growth Rate Less (Various Versions of) the Weighted Sum of the Sectoral Real Growth Rates

\begin{tabular}{|c|c|c|c|c|c|c|c|c|c|c|}
\hline & \multicolumn{8}{|c|}{ Production approach } & & \multirow{3}{*}{$\begin{array}{l}\text { Expendi- } \\
\text { ture } \\
\text { volume }\end{array}$} \\
\hline & \multicolumn{2}{|c|}{ current-year } & \multicolumn{2}{|c|}{ previous year } & \multicolumn{2}{|c|}{ Törnqvist } & \multicolumn{2}{|c|}{ decade } & \multirow{2}{*}{$\begin{array}{l}\text { volume } \\
\text { weight } \\
\text { prev. year }\end{array}$} & \\
\hline & pre & post & pre & post & pre & post & pre & post & & \\
\hline 1978 & 0.1 & 0.1 & & & & & & & & -1.3 \\
\hline 1979 & 0.1 & 0.1 & 0.1 & 0.1 & 0.1 & 0.1 & & & 0.0 & -1.5 \\
\hline 1980 & 0.4 & 0.4 & 0.6 & 0.6 & 0.5 & 0.5 & & & 0.0 & -0.1 \\
\hline 1981 & -0.2 & -0.2 & -0.1 & -0.1 & -0.1 & -0.1 & -0.1 & & 0.0 & -2.4 \\
\hline 1982 & -0.1 & -0.1 & 0.0 & 0.0 & 0.0 & 0.0 & 0.1 & -0.1 & 0.0 & -0.4 \\
\hline 1983 & 0.1 & 0.1 & 0.2 & 0.2 & 0.1 & 0.1 & 0.1 & 0.1 & 0.0 & 1.4 \\
\hline 1984 & 0.0 & 0.0 & 0.1 & 0.2 & 0.1 & 0.1 & 0.1 & 0.1 & 0.0 & -0.4 \\
\hline 1985 & -0.3 & -0.2 & 0.4 & 0.4 & 0.1 & 0.1 & 0.0 & 0.1 & 0.0 & -1.3 \\
\hline 1986 & -0.1 & -0.1 & 0.0 & 0.0 & 0.0 & 0.0 & 0.3 & 0.1 & 0.0 & -0.1 \\
\hline 1987 & 0.1 & 0.1 & 0.1 & 0.1 & 0.1 & 0.1 & 0.5 & 0.3 & 0.0 & 2.6 \\
\hline 1988 & 0.3 & 0.3 & 0.4 & 0.4 & 0.3 & 0.3 & 0.7 & 0.5 & 0.0 & 2.7 \\
\hline 1989 & 0.0 & 0.0 & 0.0 & 0.0 & 0.0 & 0.0 & 0.2 & 0.7 & 0.0 & 2.1 \\
\hline 1990 & -0.2 & -0.2 & -0.1 & -0.1 & -0.2 & -0.2 & -0.4 & 0.2 & 0.0 & -3.9 \\
\hline 1991 & -0.2 & -0.2 & 0.0 & 0.0 & -0.1 & -0.1 & 0.0 & -0.4 & 0.0 & -2.4 \\
\hline 1992 & -0.4 & -0.3 & 0.0 & 0.0 & -0.2 & -0.2 & 0.2 & 0.0 & 0.0 & 1.0 \\
\hline 1993 & -0.4 & -0.3 & 0.1 & 0.1 & -0.2 & -0.1 & 0.6 & 0.2 & 0.0 & 3.0 \\
\hline 1994 & -0.1 & 0.0 & -0.1 & 0.0 & -0.1 & 0.0 & 0.9 & 0.7 & 0.0 & 1.8 \\
\hline 1995 & 0.1 & 0.1 & 0.2 & 0.1 & 0.1 & 0.1 & 0.7 & 0.9 & 0.0 & 0.2 \\
\hline 1996 & 0.2 & 0.2 & 0.2 & 0.2 & 0.2 & 0.2 & 0.7 & 0.7 & 0.0 & -0.5 \\
\hline 1997 & 0.1 & 0.0 & 0.1 & 0.1 & 0.1 & 0.1 & 0.6 & 0.6 & 0.0 & 2.0 \\
\hline 1998 & 0.1 & 0.0 & 0.1 & 0.1 & 0.1 & 0.0 & 0.6 & 0.6 & 0.0 & 0.9 \\
\hline 1999 & 0.1 & -0.1 & 0.1 & 0.0 & 0.1 & 0.0 & 0.6 & 0.5 & 0.0 & 0.7 \\
\hline 2000 & 0.2 & -0.1 & 0.3 & 0.0 & 0.2 & 0.0 & 0.9 & 0.6 & 0.0 & -0.3 \\
\hline 2001 & 0.0 & -0.1 & 0.0 & 0.0 & 0.0 & 0.0 & 0.0 & 0.8 & 0.0 & -0.6 \\
\hline 2002 & -0.1 & 0.0 & 0.0 & 0.1 & 0.0 & 0.0 & 0.0 & 0.0 & 0.0 & -0.3 \\
\hline 2003 & -0.1 & -0.1 & 0.0 & 0.0 & 0.0 & 0.0 & 0.1 & 0.1 & 0.0 & 0.0 \\
\hline 2004 & 0.0 & 0.0 & 0.0 & 0.0 & 0.0 & 0.0 & 0.1 & 0.1 & 0.0 & -0.5 \\
\hline 2005 & & 0.0 & & 0.1 & & 0.0 & & 0.1 & 0.0 & \\
\hline 2006 & & -0.1 & & 0.0 & & 0.0 & & 0.2 & 0.0 & \\
\hline 2007 & & 0.0 & & 0.0 & & 0.0 & & 0.3 & 0.0 & \\
\hline 2008 & & 0.0 & & 0.0 & & 0.0 & & 0.5 & 0.0 & \\
\hline 2009 & & 0.0 & & 0.0 & & 0.0 & & 0.2 & 0.0 & \\
\hline 2010 & & 0.0 & & 0.0 & & 0.0 & & 0.3 & 0.0 & \\
\hline 2011 & & 0.0 & & 0.0 & & 0.0 & & 0.3 & & \\
\hline Sum abs. dev. & 3.9 & 3.6 & 3.4 & 3.1 & 3.2 & 2.9 & 8.5 & 10.5 & 0.0 & 34.4 \\
\hline Maximum & 0.39 & 0.28 & 0.56 & 0.40 & 0.47 & 0.34 & 0.90 & 0.91 & 0.0 & 3.0 \\
\hline Minimum & -0.39 & -0.35 & -0.14 & -0.14 & -0.20 & -0.18 & -0.44 & -0.44 & 0.0 & -3.9 \\
\hline Average & -0.01 & -0.04 & 0.11 & 0.08 & 0.05 & 0.02 & 0.31 & 0.33 & 0.00 & 0.09 \\
\hline Standard dev. & 0.18 & 0.14 & 0.15 & 0.12 & 0.15 & 0.11 & 0.34 & 0.31 & 0.00 & 1.64 \\
\hline
\end{tabular}

"Pre" and "post" refers to pre-economic census 2004 data and post-economic census 2008 data.

Sectoral growth rates are those of the primary, secondary, and tertiary sectors. 
Nominal weights are provided by the shares of sectoral nominal value-added in nominal GDP. Törnqvist weights are the geometric means of previous-year and current-year nominal shares.

Decade weights are the nominal weights of 1980, 1990, and 2000. 1980 weights are applied to the growth rates of 1981-1990, and similarly for the other decades.

"Vol. weight prev. year" refers to previous year weights using post-economic census data, where these weights consist of real (volume) GDP as provided by the NBS in a table with real GDP in base year prices. Base years are 1970 (which applies to 1978-1980), 1980, 1990, 2000, and 2005. These base year values do not perfectly match the official nominal GDP values in 1980 and 1990 (incl. primary sector value-added in 1980 and tertiary sector value-added in 1980 and 1990). The summed absolute deviations if the other three methods of combining sectoral real growth rates are applied to these real GDP data are 3.9 (current-year weight), 1.9 (Törnqvist index), and 9.1 (decade weights).

"Expenditure volume" is the difference between the official (production approach) real GDP growth rate and a constructed expenditure real growth rate. All data are post-economic census data. Expenditure real growth rates are obtained from the sum of real final consumption, real gross capital formation, and real net exports (with base years 1970, 1980, 1990, and 2000). Real final consumption and real gross capital formation are calculated from the available nominal data and real growth rates; real net exports are constructed from the available nominal data and the implicit (production approach) GDP deflator.

Source: pre-economic census production approach values: Statistical Yearbook 2005, pp. 51, 53; posteconomic census production approach values: Statistical Yearbook 2012, pp. 44, 46f.; post-economic census expenditure data: GDP 1952-2004, pp. 3-5, 19, 22, 25, 26. 
Table 14. Deflators for Industrial Output

\begin{tabular}{|c|c|c|c|c|c|c|c|c|c|c|c|c|}
\hline & \multicolumn{3}{|c|}{ Industrial value-added } & \multicolumn{2}{|c|}{ Industrial $\mathrm{GOV}^{\mathrm{a}}$} & \multicolumn{2}{|c|}{ DRIEs GOV ${ }^{\mathrm{a}, \mathrm{c}}$} & \multirow{2}{*}{$\begin{array}{l}\text { GOV of } \\
\text { ind. ent. at tsh. } \\
\text { level \& above }\end{array}$} & \multicolumn{3}{|c|}{ Price indices } & \multirow{2}{*}{$\begin{array}{c}\text { Double- } \\
\text { deflated } \\
\text { value- } \\
\text { added }^{\text {f }}\end{array}$} \\
\hline & $\begin{array}{l}\text { Pre- } \\
\text { economic } \\
\text { census }\end{array}$ & $\begin{array}{l}\text { Post- } \\
\text { economic } \\
\text { census }\end{array}$ & $\begin{array}{c}\text { As first } \\
\text { published }\end{array}$ & $\begin{array}{l}\text { Statistical } \\
\text { Yearbook } \\
\text { issues }\end{array}$ & $\begin{array}{c}\text { Summed } \\
\text { provinces }^{b}\end{array}$ & $\begin{array}{c}\text { All } \\
\text { DRIEs }\end{array}$ & SOEs & & $\begin{array}{l}\text { Ex-fac- } \\
\text { tory price } \\
\text { index }\end{array}$ & $\begin{array}{c}\text { Raw } \\
\text { material pr. } \\
\text { index }\end{array}$ & $\begin{array}{c}\text { Purchasing } \\
\text { price } \\
\text { index }\end{array}$ & \\
\hline 1979 & 1.3 & 1.3 & & 1.5 & 1.1 & & & 1.6 & 1.5 & & & \\
\hline 1980 & 0.1 & 0.1 & & 0.8 & 0.3 & & & 0.4 & 0.5 & & & \\
\hline 1981 & 0.8 & 0.8 & & 0.5 & 0.5 & & & 0.4 & 0.2 & & & \\
\hline 1982 & -0.2 & -0.2 & & -0.2 & -0.3 & & & -0.2 & -0.2 & & & \\
\hline 1983 & 0.1 & 0.1 & & 0.0 & 0.0 & & & 0.0 & -0.1 & & & \\
\hline 1984 & 2.2 & 2.2 & & 1.4 & 1.3 & & & 1.4 & 1.4 & & & \\
\hline 1985 & 4.6 & 4.6 & & 5.1 & 5.0 & & & 5.4 & 8.7 & 10.9 & 18.0 & -4.9 \\
\hline 1986 & 4.9 & 4.9 & & 3.2 & 2.9 & & & 3.3 & 3.8 & 7.5 & 9.5 & -3.6 \\
\hline 1987 & 2.1 & 2.1 & & 4.8 & 5.1 & & & 5.2 & 7.9 & 6.9 & 11.0 & 1.8 \\
\hline 1988 & 9.3 & 9.3 & & 9.2 & 8.7 & & & 9.9 & 15.0 & 13.5 & 20.2 & 6.8 \\
\hline 1989 & 6.8 & 6.8 & & 11.3 & 11.1 & & & 12.4 & 18.6 & 16.4 & 26.4 & 6.1 \\
\hline 1990 & 2.3 & 2.3 & 1.9 & 0.8 & 0.9 & & & 1.1 & 4.1 & 5.9 & 5.6 & 0.9 \\
\hline 1991 & 3.1 & 3.1 & 4.9 & -3.0 & 3.2 & & & 3.6 & 6.2 & 11.8 & 9.1 & 6.4 \\
\hline 1992 & 5.0 & 5.0 & 3.9 & 4.2 & 1.4 & & & 3.5 & 6.8 & 10.2 & 11.0 & 1.5 \\
\hline 1993 & 14.5 & 14.9 & 13.5 & 9.9 & 13.4 & & & 13.3 & 24.0 & 40.4 & 35.1 & 13.5 \\
\hline 1994 & 15.1 & 15.5 & 10.0 & 16.7 & 8.6 & 7.5 & 12.4 & 7.9 & 19.5 & 17.9 & 18.2 & 16.2 \\
\hline 1995 & 12.0 & 12.3 & 10.0 & 8.9 & 8.1 & 9.3 & 9.5 & 9.8 & 14.9 & 13.6 & 15.3 & 12.6 \\
\hline 1996 & 4.6 & 4.9 & 4.6 & 3.8 & $*-3.0$ & 0.5 & 0.6 & 0.3 & 2.9 & 1.7 & 3.9 & \\
\hline 1997 & 0.1 & 0.4 & -1.7 & 1.0 & -1.6 & -2.6 & -1.4 & -2.4 & -0.3 & 0.0 & 1.3 & \\
\hline 1998 & -5.4 & -5.1 & -5.3 & -5.5 & -5.1 & $*_{-}-2.4$ & *-10.0 & & -4.1 & -6.6 & -4.2 & \\
\hline 1999 & -3.2 & -2.9 & -3.5 & -5.1 & -4.2 & -4.6 & -2.8 & & -2.4 & -1.8 & -3.3 & \\
\hline 2000 & 1.4 & 1.7 & 2.6 & & 0.8 & 0.8 & 4.0 & & 2.8 & 8.4 & 5.1 & \\
\hline 2001 & -0.2 & 0.2 & 0.2 & & -1.9 & -2.8 & -3.0 & & -1.3 & -0.3 & -0.2 & \\
\hline 2002 & -1.4 & -1.0 & -0.2 & & -1.7 & -1.8 & -1.5 & & -2.2 & -2.0 & -2.3 & \\
\hline 2003 & 2.4 & 2.7 & 2.4 & & & 2.3 & 3.6 & & 2.3 & 6.7 & 4.8 & \\
\hline 2004 & 6.1 & 6.4 & 6.1 & & & 0.5 & & & 6.1 & 10.2 & 11.4 & \\
\hline 2005 & & 6.1 & 5.7 & & & & & & 4.9 & 9.8 & 8.3 & \\
\hline 2006 & & 4.7 & 4.7 & & & & & & 3.0 & 6.6 & 6.0 & \\
\hline
\end{tabular}




\begin{tabular}{|c|c|c|c|c|c|c|c|c|c|c|c|}
\hline 2007 & 5.4 & 3.6 & & & & & & 3.1 & 5.6 & 4.4 & \\
\hline 2008 & 7.2 & 6.7 & & & & & & 6.9 & 8.9 & 10.5 & \\
\hline 2009 & -4.5 & -4.5 & & & & & & -5.4 & -8.1 & -7.9 & \\
\hline 2010 & 6.0 & 6.0 & & & & & & 5.5 & 10.1 & 9.6 & \\
\hline 2011 & 6.2 & 6.2 & & & & & & 6.0 & 9.2 & 9.1 & \\
\hline \multicolumn{12}{|c|}{ (1) Average annual absolute difference between the deflator of pre-economic census industrial value-added and the alternative deflator } \\
\hline All years & & & 1.6 & 1.8 & 2.8 & 2.3 & 1.8 & 2.9 & 5.8 & 6.3 & 2.9 \\
\hline 1979-1997 & & & 1.6 & 2.0 & 4.3 & 2.7 & 1.8 & 3.0 & 6.0 & 7.8 & 2.9 \\
\hline 1985-1997 & & & 2.2 & 2.8 & 4.3 & 2.7 & 2.5 & 4.2 & 6.0 & 7.8 & 2.9 \\
\hline 1998-2007 & & & 1.0 & 0.8 & 2.0 & 2.0 & & 2.9 & 5.5 & 5.0 & \\
\hline 1998-2003 & & & 1.0 & 0.8 & 1.6 & 2.1 & & 1.1 & 2.1 & 1.2 & \\
\hline 2004-2007 & & & & & 5.7 & & & 4.4 & 7.8 & 7.6 & \\
\hline \multicolumn{12}{|c|}{ (2) Average annual absolute difference between the deflator of post-economic census industrial value-added and the alternative deflator } \\
\hline All years & & & 1.6 & 1.9 & 3.1 & 2.4 & 1.9 & 2.1 & 4.2 & 4.9 & 2.9 \\
\hline 1979-1997 & & & 1.7 & 2.1 & 4.6 & 3.0 & 1.9 & 2.9 & 6.0 & 7.7 & 2.9 \\
\hline 1985-1997 & & & 2.3 & 2.9 & 4.6 & 3.0 & 2.6 & 4.1 & 6.0 & 7.7 & 2.9 \\
\hline 1998-2007 & & & 1.3 & 1.0 & 2.2 & 2.0 & & 0.9 & 2.6 & 2.2 & \\
\hline 1998-2003 & & & 1.3 & 1.0 & 1.8 & 2.2 & & 1.0 & 2.1 & 1.3 & \\
\hline 2004-2007 & & & & & 6.0 & & & 0.9 & 2.7 & 2.8 & \\
\hline \multicolumn{12}{|c|}{ (3) Average annual absolute difference between the deflator of industrial value-added as first published and the alternative deflator } \\
\hline All years & & & 2.6 & 1.8 & 2.2 & 2.0 & 1.2 & 2.1 & 4.6 & 3.9 & 2.3 \\
\hline 1979-1997 & & & 3.0 & 2.1 & 2.0 & 1.8 & 1.2 & 4.3 & 7.5 & 6.7 & 2.3 \\
\hline 1985-1997 & & & 3.0 & 2.1 & 2.0 & 1.8 & 1.2 & 4.3 & 7.5 & 6.7 & 2.3 \\
\hline 1998-2007 & & & 0.9 & 1.3 & 2.3 & 2.1 & & 0.8 & 2.9 & 2.3 & \\
\hline 1998-2003 & & & 0.9 & 1.3 & 2.1 & 2.3 & & 1.2 & 2.2 & 1.3 & \\
\hline 2004-2007 & & & & & 5.6 & & & 0.6 & 3.1 & 3.0 & \\
\hline
\end{tabular}


* denotes values that may suffer from a statistical break.

a The definition of GOV changed in 1995, with 1995 data available according to both the old and the new stipulations; the new stipulations introduced four differences, of which the most significant one is that since 1995 the value-added tax is not included in GOV (for details see Carsten Holz and Yi-min Lin, 2001a). In calculating the deflator, the 1995 data according to the old stipulations were used for the 1995 deflator, and the 1995 data according to the new stipulations for the 1996 deflator.

b The national industrial GOV deflator is derived by comparing the summed provincial nominal industrial GOV to the summed provincial real industrial GOV growth rate. The summed provincial real industrial GOV growth rate is obtained by weighting provincial growth rates with the average of previous-year and current year provincial shares in summed provincial nominal industrial GOV, i.e., for simplicity, the "In version" of the Törnqvist index is used (making use of the fact that, for example, $\ln (1.05) \approx 5$ percent $)$.

For Tibet, values are only available since 1994; the contribution of Tibet's 1994 real growth rate to the summed provincial real growth rate uses only the year 1994 provincial nominal value (divided by the summed provincial value) rather than 1993 and 1994 nominal values as weight. For Hainan, nominal values are available starting in 1990, and real growth rates starting in 1991. Prior to 1990, Hainan could be included in the Guangdong data in the source, but probably are not. Chongqing data start in 1995/1996; prior to 1996, Chongqing is included in the Sichuan data.

The summed provincial industrial GOV exceeds the national industrial GOV in the Statistical Yearbook issues since 1991; the source of the provincial industrial GOV data, GDP 1952-95 and GDP 1952-95, do not incorporate the revisions following the industrial census of 1995. But the discrepancy also continues after 1995; it is never larger than 9 percent of the national value.

c In 1998, the group of DRIEs was redefined from "industrial enterprises with independent accounting systems at the township level and above" to "industrial SOSCEs with independent accounting systems and all industrial non-SOSCEs with independent accounting systems and annual sales revenue in excess of $5 \mathrm{~m}$ yuan.”

The deflators for 1991-2003 are derived from the "constant 1990 price” and current price GOV series; the fact that there is no "constant 2000 price" GOV series suggests that the 1990 price manual has been in use at least through 2003. For 2004, a real growth rate instead of a value in constant 1990 prices is published.

d GOV of ind. ent. at tsh. level \& above: GOV of industrial enterprises at township level and above. e Purchasing price index: purchasing price index of raw materials, fuel, and power.

f Industrial value-added obtained via deflated industrial GOV and deflated intermediate inputs: a series of real industrial value-added is constructed first, which is then contrasted to the Statistical Yearbook 2005 series of nominal industrial value-added in the NIPA. Real industrial value-added is the difference of industrial GOV (the nominal data underlying the fourth data column), deflated by the ex-factory price index, and the value of intermediate inputs, deflated by the purchasing price index. The value of intermediate inputs is obtained as nominal industrial GOV less nominal industrial value-added. The calculated series ends in 1995 due to the change in the definition of GOV with a lack of data on the valueadded tax that would be needed for a continuation of the calculations after 1995.

Sources:

Pre-economic census: Statistical Yearbook 2005, pp. 51, 53. 1981, 1986, and 1992 values were taken from the post-economic census Statistical Yearbook 2008, because the electronic version of this source contains real growth rates at a much higher degree of precision (in the electronic version of the Statistical Yearbook 2005, real growth rates come with one decimal, as in the print version); the real growth rates and implicit deflators of 1979-1992 are identical in the two sources if the same degree of precision is used.

Post-economic census: Statistical Yearbook 2012, pp. 44, 47.

As first published: Statistical Yearbook series starting with 1991 issue (when data on industrial valueadded were first published). 
Industrial GOV: Statistical Yearbook issues: Statistical Yearbook 1993, p. 412; 1996, p. 403, 1997, p. 413, 2000, p. 409; summed provinces: GDP 1952-95, GDP 1996-2002 (pages of each individual province). DRIEs GOV: Industrial Yearbook 1994, pp. 81, 84; 1995, pp. 79, 82; 1998, p. 77; Industrial Census 1995, pp. 46f.; Statistical Yearbook 2004, p. 514; 2005, p. 488; Fifty-five Years, pp. 36f.

Industrial enterprises at the township level and above: Seventeen Years, p. 145.

Price indices: ex-factory price index (more recently, in English only, relabeled "producer price index for manufactured goods): Statistical Yearbook 1994, p. 246; 2004, p. 323; 2005, p. 301, 2008, p. 281; raw materials price index (a sub-index of the price index of means of production, which in turn is a sub-index of the ex-factory price index): Price Yearbook 1992, p. 538; Statistical Yearbook 1995, p. 249; 2001, p. 297; 2008, p. 304; purchasing price index of raw material, fuel, and power: Price Yearbook 1992, p. 538; Statistical Yearbook 2004, p. 323; 2005, p. 301; 2008, p. 281; 2012, pp. 331, 334. 


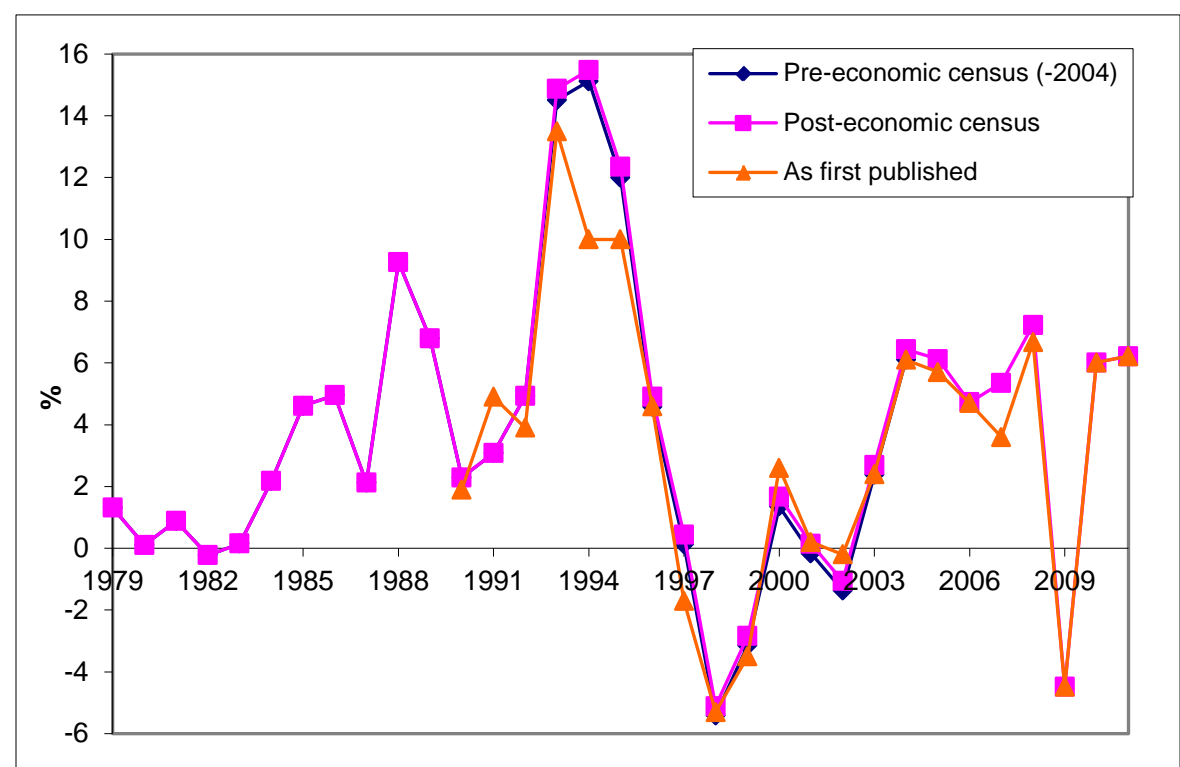

Sources: see Table 14.

Figure 5. Industrial Value-Added Deflators

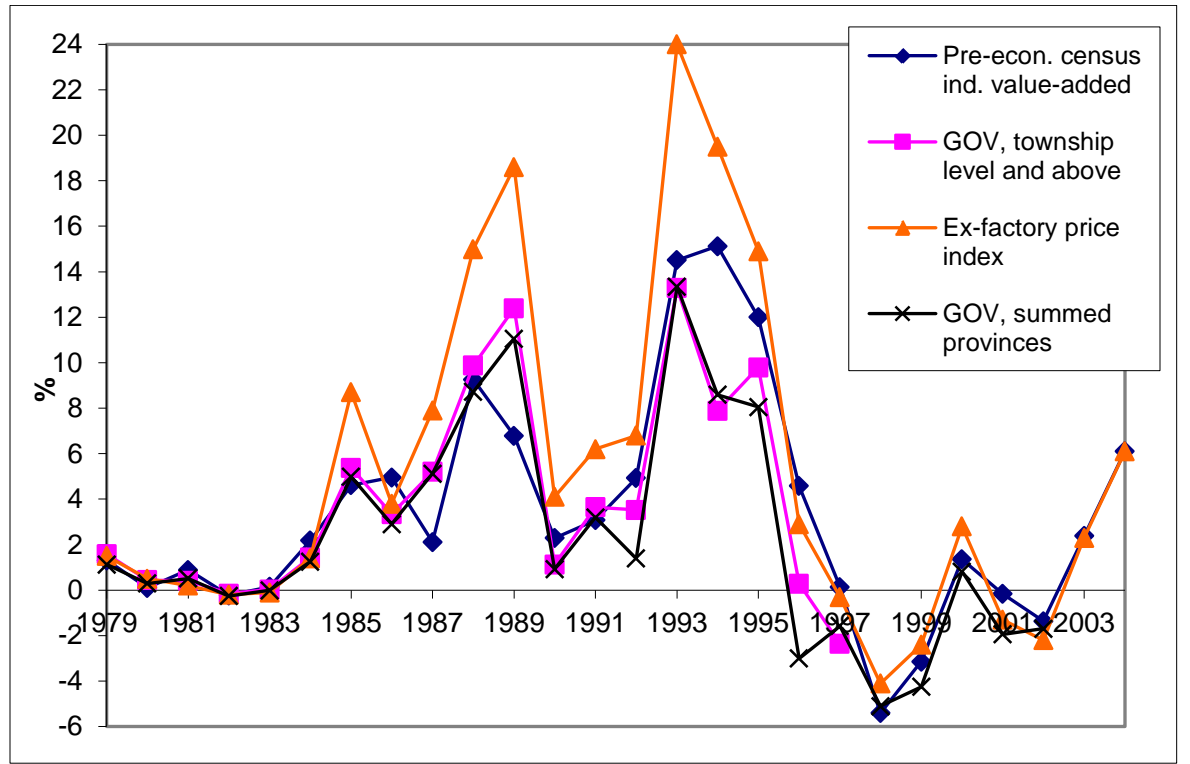

Sources: see Table 14.

Figure 6. Alternative Industrial Deflators 
Table 15. Expenditure Deflators and Price Indices

\begin{tabular}{|c|c|c|c|c|c|c|c|c|c|c|c|c|c|}
\hline & \multicolumn{10}{|c|}{ Consumption } & \multicolumn{3}{|c|}{ Fixed capital formation } \\
\hline & \multicolumn{3}{|c|}{ Household } & \multirow{2}{*}{ CPI } & \multirow{2}{*}{$\begin{array}{l}\text { \# Rural } \\
\text { Aggre- } \\
\text { gate }\end{array}$} & \multirow{2}{*}{$\begin{array}{l}--- \\
\text { Per } \\
\text { capita }\end{array}$} & \multirow{2}{*}{ CPI } & \multirow{2}{*}{$\begin{array}{l}\text { \# Urban } \\
\text { Aggre- } \\
\text { gate }\end{array}$} & \multirow{2}{*}{$\begin{array}{c}--- \\
\text { Per } \\
\text { capita }\end{array}$} & \multirow[t]{2}{*}{ Gov. } & \multirow{2}{*}{$\begin{array}{l}\text { Fixed } \\
\text { asset } \\
\text { prices }\end{array}$} & \multirow[t]{2}{*}{ GFCF } & \multirow{2}{*}{$\begin{array}{l}\text { Inven- } \\
\text { tory } \\
\text { change }\end{array}$} \\
\hline & CPI & $\begin{array}{l}\text { Aggre- } \\
\text { gate }\end{array}$ & $\begin{array}{c}\text { Per } \\
\text { capita }\end{array}$ & & & & & & & & & & \\
\hline 1979 & & 5.6 & 5.7 & & 7.9 & 8.2 & 1.9 & 2.0 & 2.1 & 0.9 & & 2.2 & 8.1 \\
\hline 1980 & 7.5 & 4.9 & 5.0 & & 3.5 & 3.3 & 7.5 & 7.4 & 7.3 & 4.6 & & 3.0 & -1.9 \\
\hline 1981 & & 2.8 & 2.4 & & 3.0 & 2.8 & 2.5 & 2.5 & 2.4 & 0.6 & & 3.2 & 0.7 \\
\hline 1982 & & 1.9 & 2.1 & & 1.8 & 1.7 & 2.0 & 2.1 & 2.2 & -0.4 & & 2.3 & 2.7 \\
\hline 1983 & & 1.5 & 1.5 & & 1.1 & 1.4 & 2.0 & 2.0 & 2.0 & 0.0 & & 2.5 & 3.6 \\
\hline 1984 & & 2.0 & 2.0 & & 1.8 & 1.7 & 2.7 & 2.6 & 2.6 & 0.7 & & 4.1 & 1.8 \\
\hline 1985 & 9.3 & 8.9 & 8.9 & 7.6 & 7.2 & 7.3 & 11.9 & 11.4 & 11.4 & 3.1 & & 7.2 & 7.9 \\
\hline 1986 & 6.5 & 6.4 & 6.4 & 6.1 & 5.9 & 5.9 & 7.0 & 6.8 & 6.8 & 3.1 & & 6.4 & 4.4 \\
\hline 1987 & 7.3 & 7.3 & 7.2 & 6.2 & 6.3 & 6.2 & 8.8 & 8.4 & 8.4 & 2.8 & & 5.2 & 10.7 \\
\hline 1988 & 18.8 & 17.3 & 17.2 & 17.5 & 14.9 & 14.9 & 20.7 & 19.8 & 19.7 & 11.3 & & 13.6 & 14.1 \\
\hline 1989 & 18.0 & 10.6 & 10.6 & 19.3 & 9.8 & 9.7 & 16.3 & 10.9 & 11.0 & 13.9 & & 8.5 & 10.9 \\
\hline 1990 & 3.1 & 1.8 & 1.9 & 4.5 & 2.7 & 2.8 & 1.3 & 0.3 & 0.3 & 1.5 & & 5.5 & 7.9 \\
\hline 1991 & 3.4 & 3.1 & 3.0 & 2.3 & 2.0 & 2.0 & 5.1 & 4.1 & 4.1 & 5.3 & 9.5 & 8.5 & 4.9 \\
\hline 1992 & 6.4 & 5.6 & 5.7 & 4.7 & 5.2 & 5.3 & 8.6 & 5.9 & 5.9 & 8.6 & 15.3 & 13.0 & 14.2 \\
\hline 1993 & 14.7 & 15.1 & 15.1 & 13.7 & 12.2 & 12.2 & 16.1 & 17.1 & 17.1 & 18.2 & 26.6 & 25.1 & 24.5 \\
\hline 1994 & 24.1 & 25.8 & 25.8 & 23.4 & 25.0 & 25.1 & 25.0 & 26.2 & 26.2 & 22.0 & 10.4 & 10.3 & 13.5 \\
\hline 1995 & 17.1 & 19.2 & 19.2 & 17.5 & 18.6 & 18.4 & 16.8 & 19.4 & 19.4 & 5.5 & 5.9 & 6.0 & 17.3 \\
\hline 1996 & 8.3 & 8.2 & 8.3 & 7.9 & 8.1 & 8.2 & 8.8 & 8.5 & 8.5 & 7.1 & 4.0 & 3.9 & 5.3 \\
\hline 1997 & 2.8 & 3.0 & 3.0 & 2.5 & 2.6 & 2.7 & 3.1 & 3.0 & 3.0 & 4.6 & 1.7 & 1.7 & -10.6 \\
\hline 1998 & -0.8 & -0.6 & -0.6 & -1.0 & -0.8 & -0.7 & -0.6 & -0.9 & -0.9 & 0.3 & -0.2 & 0.0 & -7.7 \\
\hline 1999 & -1.4 & -2.1 & -2.2 & -1.5 & -2.9 & -2.9 & -1.3 & -2.0 & -2.0 & 1.8 & -0.4 & -0.4 & 13.8 \\
\hline 2000 & 0.4 & 0.0 & 0.0 & -0.1 & 0.8 & 0.8 & 0.8 & -0.8 & -0.8 & 2.1 & 1.1 & 1.1 & -16.5 \\
\hline 2001 & 0.7 & 0.9 & 0.8 & 0.8 & 1.3 & 1.3 & 0.7 & 0.6 & 0.6 & 1.0 & 0.4 & 0.4 & -1.0 \\
\hline 2002 & -0.8 & -0.3 & -0.4 & -0.4 & -0.4 & -0.5 & -1.0 & -0.4 & -0.3 & -0.5 & 0.2 & 0.2 & 1.5 \\
\hline 2003 & 1.2 & 0.8 & 0.9 & 1.6 & 1.6 & 1.7 & 0.9 & 0.6 & 0.6 & 1.0 & 2.2 & 2.3 & 1.1 \\
\hline 2004 & 3.9 & 3.9 & 4.0 & 4.8 & 5.8 & 5.8 & 3.3 & 3.3 & 3.2 & 3.7 & 5.6 & 6.2 & 5.4 \\
\hline
\end{tabular}

All implicit deflators are post-economic census values (which are near-identical to pre-economic census values, available through 2002, see Table 8).

Househ. consumption: All household consumption.

Gov.: Government

GFCF: Gross fixed capital formation.

Fixed asset prices: Investment in fixed assets price index.

CPI: Consumer Price Index (total, rural, urban).

Sources: price indices: Statistical Yearbook 2008, p. 281, 1998, p. 301; implicit deflators: see Table 8. 


\section{References}

Chinese names are given last name first if they appear in pinyin notation in the original source.

To avoid confusion between pinyin and non-pinyin names, when last names are rendered first in Chinese-sounding names, these last names are fully capitalized.

BAI Chong-en, and QIAN Zhenjie. "Guomin shouru de yaosu fenpei: tongji shuju beihou de gushi” (Factor contribution: the story behind the numbers). Unpublished and undated manuscript, obtained December 2009.

BAI Chong-en, and QIAN Zhenjie. “The Factor Distribution in China: 1978-2007.” China Economic Review 21, no. 4 (Dec. 2010): 650-70.

China Infobank. (Internet database on, among others, news items, and laws and regulations, at http://www.chinainfobank.com).

29 February 2000. “Zhongguo tongjiju zhang 'bamai’ tongji shuzi” (The head of China’s statistics office 'gets a grip' on the statistics).

China Markets Yearbook (Zhongguo shichang nianjian). (NBS data edited by the All China Marketing Research Co., Ltd.) Beijing: Foreign Languages Press, various years. The (presumably) first issue was published as China Industrial Markets Yearbook 1997 by the City University of Hong Kong Press.

Economic Census 2004. Zhongguo jingji pucha nianjian-2004 (China Economic Census Yearbook-2004). Four volumes. Beijing: Zhongguo tongji chubanshe, (May) 2006.

Economic Census 2004 (9 Jan. 2006). "Guanyu wo guo guonei shengchan zongzhi lishi shuju xiuding jieguo de gonggao" (Announcement of the results of the historic revisions of China's GDP data). http://www.stats.gov.cn/tjdt/zygg/t20060109_402300176.htm (accessed on 27 April 2006). Also, on 8 March 2006, "Jingji pucha hou zhongguo GDP shuju jiedu zhi yi: GDP zongliang, zengzhang sudu ji renjun GDP” (China’s GDP figures after the economic census, part 1: GDP volume, GDP increase, and per capita GDP), http://www.stats.gov.cn/zgjjpc/cgfb/ (accessed on 27 April 2006).

Economic Census 2008. Zhongguo jingji pucha nianjian-2008 (China Economic Census Yearbook-2008). Five volumes. Beijing: Zhongguo tongji chubanshe, (May) 2010.

Fifty Years. Xin zhongguo wushi nian tongji ziliao huibian (Comprehensive statistical materials on 50 years of new China). Beijing: Zhongguo tongji chubanshe, 1999.

Fifty-five Years. Xin zhongguo wushiwu nian tongji ziliao huibian (Comprehensive statistical materials on 55 years of new China [1949-2004]). Beijing: Zhongguo tongji chubanshe, 2005.

GDP 1952-95. Zhongguo guonei shengchan zongzhi hesuan lishi ziliao 1952-1995 (Historical data on China's gross domestic product 1952-1995). Dalian: Dongbei caijing daxue chubanshe, 1997.

GDP 1952-96. Zhongguo guonei shengchan zongzhi hesuan lishi ziliao (zhaiyao, 1952-1996) (Historical data on China’s gross domestic product (abstract, 1952-1996)). Beijing: Zhongguo tongji chubanshe, 1998.

GDP 1952-2004. Zhongguo guonei shengchan zongzhi hesuan lishi ziliao 1952-2004 (Historical data on China’s gross domestic product 1952-2004). Beijing: Zhongguo tongji chubanshe, 2007.

GDP 1996-2002. Zhongguo guonei shengchan zongzhi hesuan lishi ziliao 1996-2002 (Historical data on China’s gross domestic product 1996-2002). Beijing: Zhongguo tongji chubanshe, 2003. 
GDP Manual. Zhongguo guonei shengchan zhongzhi hesuan shouce (Manual for GPD calculation in China). Compiled by the NBS National Income Accounts Division. Beijing: Zhongguo tongjiju guomin jingji hesuansi, 2001.

Holz, Carsten. "Institutional Constraints on the Quality of Statistics in a Developing and Transitional Economy: the Case of China.” China Information 16, no. 1 (2002): 25-67. “'Fast, Clear and Accurate:' How Reliable Are Chinese Output and Economic Growth Statistics?” The China Quarterly, no. 173 (March 2003): 122-63. . "Deconstructing China's GDP Statistics.” China Economic Review 15, no. 2 (2004a):

164-202. . “China’s Reform Period Economic Growth: How Reliable Are Angus Maddison's Estimates? Review of Income and Wealth 52, no. 1 (March 2006a): 85-119. . "Chinese Statistics: Classification Systems and Data Sources.” Mimeo, 7 January 2013.

Holz, Carsten A., and Yi-min Lin. "Pitfalls of China's Industrial Statistics: Inconsistencies and Specification Problems.” The China Review 1, no. 1 (Fall 2001a): 29-71. . "The 1997-1998 Break in Industrial Statistics: Facts and Appraisal." China Economic Review 12, no. 4 (2001b): 303-16.

Industrial Census 1995. Zhonghua renmin gongheguo 1995 nian quanguo gongye pucha ziliao (Materials of the 1995 PRC national industrial census). Three volumes. Beijing: Zhongguo tongji chubanshe, 1997.

Industrial Yearbook. Zhongguo gongye jingji tongji nianjian (China Industrial Economy Statistical Yearbook). Beijing: Zhongguo tongji chubanshe, various issues. (The following issues, with the year in the title, have so far been published: 1988, 1989, 1990, 1991, 1992, 1993, 1994, 1995, 1998, 2001, 2002, 2003, 2004, 2006, 2007, 2008, 2009, 2010, 2011. The predecessor is the Zhongguo gongye jingji tongji ziliao (China Industrial Statistical Material), Beijing: Zhongguo tongji chubanshe, 1949-1984, 1986, 1987.

Industry, Transport, and Energy 50 Years. Zhongguo gongye jiaotong nengyuan 50 nian tongji ziliao huibian 1949-1999 (Compendium of 50 Years of Statistics on China’s Industry, Transport and Energy, 1949-1999). Compiled by the NBS Industry and Transport Statistics Division. Beijing: Zhongguo tongji chubanshe, 2000.

Labor Yearbook. Zhongguo laodong tongji nianjian (China Labor Statistical Yearbook). Beijing: Zhongguo tongji chubanshe, various years since the 1991 issue. A 1989 and a 1990 issue are available of Zhongguo laodong gongzi tongji nianjian (China Labor and Wage Statistical Yearbook) by the same publisher.

LIU Xiaoyue. "Paiyou jienan zhong zai jiceng: baixian diaoyan hainanzu you gan er fa" (The key to solving the worries lies at the grassroots: reflections of the Hainan group of the hundred-county-survey campaign). Zhongguo tongji, no. 8 (Aug. 2006): 10-12.

Maddison, Angus. Chinese Economic Performance in the Long Run. Paris: Development Centre of the Organisation for Economic Co-operation and Development, 1998.

NBS. National Bureau of Statistics.

30 Sept. 1990. "1990 nian gongye chanpin bubian jiage” (1990 constant prices of industrial products). In NBS (1995), pp. 768-72.

1995. Tongji zhidu fangfa wenjian xuanbian 1987-1993 (Selected documents on the methods of the statistical system 1987-1993). Beijing, Guojia tongiju tongji sheji guanlisi (Design and Administration Department of the NBS), no specific publisher, 1995.

1997. Zhongguo niandu guonei shengchan zongzhi jisuan fangfa (Calculation method of China's annual gross domestic product). NBS National Income Accounts Division. Beijing: Zhongguo tongji chubanshe. (This is one of seven small volumes explaining compilation practices of different NIPA statistics in China.) 
2007. Zhongguo jingji pucha niandu guonei shengchan zongzhi hesuan fangfa (Calculation method of China's annual gross domestic product from China's economic census). NBS National Income Accounts Division. Beijing: Zhongguo tongji chubanshe, 2007.

PAN Zhenwen, and AN Yuli. "Yi wan yi de chaju cong he er lai: dui guojiaji, shengji hesuan shuju chaju de sikao" (Where is the one-trillion difference from? Some thoughts on the difference between national and provincial accounts data). Zhongguo tongji, no. 11 (Nov. 2003): 8f.

SC. State Council (guowuyuan). All items from China Infobank unless otherwise noted. 5 September 2004. “'Quanguo jingji pucha tiaoli' shiyi” (Explanation of the 'national stipulation on the economic census'). Issued in collaboration with the NBS.

Seventeen Years. Gaige kaifang shiqi nian de zhongguo diqu jingji (China’s Regional Economy in Seventeen Years of Reform and Opening). Beijing: Zhongguo tongji chubanshe, 1996.

Sixty Years. Xin zhongguo liushi nian tongji ziliao huibian (Comprehensive atatistical materials on 60 years of the New China [1949-2008]). Beijing: Zhongguo tongji chubanshe, 2010.

Statistical Abstract. Zhongguo tongji zhaiyao (China Statistical Abstract). Beijing: Zhongguo tongji chubanshe, various years.

Statistical Yearbook. Zhongguo tongji nianjian (China Statistical Yearbook). Beijing: Zhongguo tongji chubanshe, various years starting with the 1981 issue (1981 in the title), and since published annually, with the second issue labeled "1983."

Wu, Harry X. "China’s GDP Level and Growth Performance: Alternative Estimates and the Implications." Review of Income and Wealth 46, no. 4 (Dec. 2000): 475-99.

. "The Chinese GDP Growth Rate Puzzle: How Fast Has the Chinese Economy Grown?" Asian Economic Papers 6, no. 1 (Winter 2007): 1-23.

XIE Haiqiu and ZHANG Lihua. "Dui shouci jingji pucha ruogan wenti de sikao yu jianyi" (Thoughts and suggestions regarding some problems in the first economic census). Tongji jiaoyu, no. 2 (2006): 11-3.

XU Xianchun. Zhongguo guonei shengchan zongzhi hesuan (Calculation of China’s GDP). Beijing: Beijing daxue chubanshe, 2000(b).

. "Woguo GDP hesuan yu xianxing SNA de GDP hesuan zhijian de ruogan chayi” (Some discrepancies in China's GDP compilation in comparison to the current SNA GDP compilation methods). Jingji yanjiu, no. 11 (Nov. 2001): 63-8.

. "Guanyu jingji pucha niandu GDP hesuan de bianhua" (Changes in the calculation of annual GDP in the economic census). Jingji yanjiu, no. 2 (February), 2006: 16-20.

. "The Establishment, Reform, and Development of China's System of National Accounts." Review of Income and Wealth 55, special issue 1 (July 2009): 442-65.

Zhongguo tongji (China Statistics). Monthly magazine published by the NBS. 
Appendix 1. Nominal GDP and Sectoral Value-Added, 1952-2005 (b yuan, pre-GB2002, pre- and post-economic census 2004)

\begin{tabular}{|c|c|c|c|c|c|c|c|c|}
\hline & GDP & $\begin{array}{l}\text { Primary } \\
\text { sector }\end{array}$ & $\begin{array}{c}\text { Secondary } \\
\text { sector }\end{array}$ & $\begin{array}{c}\# \\
\text { Industry }\end{array}$ & $\begin{array}{c}\# \\
\text { Construction }\end{array}$ & $\begin{array}{c}\text { Tertiary } \\
\text { sector }\end{array}$ & $\begin{array}{c}\text { \# Transp. \& } \\
\text { communic. }\end{array}$ & $\begin{array}{l}\text { \# Comm. } \\
\text { \& cater. }\end{array}$ \\
\hline \multicolumn{9}{|c|}{ A. Pre-economic census data } \\
\hline 1952 & 67.90 & 34.29 & 14.18 & 11.98 & 2.20 & 19.43 & 2.90 & 8.03 \\
\hline 1953 & 82.40 & 37.80 & 19.25 & 16.35 & 2.90 & 25.35 & 3.50 & 11.50 \\
\hline 1954 & 85.90 & 39.20 & 21.17 & 18.47 & 2.70 & 25.53 & 3.80 & 12.03 \\
\hline 1955 & 91.00 & 42.10 & 22.22 & 19.12 & 3.10 & 26.68 & 3.90 & 11.98 \\
\hline 1956 & 102.80 & 44.39 & 28.07 & 22.47 & 5.60 & 30.34 & 4.60 & 13.14 \\
\hline 1957 & 106.80 & 43.00 & 31.70 & 27.10 & 4.60 & 32.10 & 4.90 & 13.30 \\
\hline 1958 & 130.70 & 44.59 & 48.35 & 41.45 & 6.90 & 37.76 & 7.10 & 13.66 \\
\hline 1959 & 143.90 & 38.38 & 61.55 & 53.85 & 7.70 & 43.97 & 9.40 & 14.57 \\
\hline 1960 & 145.70 & 34.07 & 64.82 & 56.82 & 8.00 & 46.81 & 10.40 & 13.31 \\
\hline 1961 & 122.00 & 44.11 & 38.89 & 36.21 & 2.68 & 39.00 & 6.92 & 11.08 \\
\hline 1962 & 114.93 & 45.31 & 35.93 & 32.54 & 3.39 & 33.69 & 5.74 & 8.05 \\
\hline 1963 & 123.33 & 49.75 & 40.76 & 36.56 & 4.20 & 32.82 & 5.50 & 7.61 \\
\hline 1964 & 145.40 & 55.90 & 51.35 & 46.11 & 5.24 & 38.15 & 5.84 & 9.40 \\
\hline 1965 & 171.61 & 65.11 & 60.22 & 54.65 & 5.57 & 46.28 & 7.74 & 11.83 \\
\hline 1966 & 186.80 & 70.22 & 70.95 & 64.86 & 6.09 & 45.63 & 8.51 & 14.81 \\
\hline 1967 & 177.39 & 71.42 & 60.28 & 54.49 & 5.79 & 45.69 & 7.23 & 15.35 \\
\hline 1968 & 172.31 & 72.63 & 53.73 & 49.03 & 4.70 & 45.95 & 7.05 & 13.89 \\
\hline 1969 & 193.79 & 73.62 & 68.91 & 62.61 & 6.30 & 51.26 & 8.49 & 16.36 \\
\hline 1970 & 225.27 & 79.33 & 91.22 & 82.81 & 8.41 & 54.72 & 10.02 & 17.81 \\
\hline 1971 & 242.64 & 82.63 & 102.28 & 92.66 & 9.62 & 57.73 & 10.84 & 17.83 \\
\hline 1972 & 251.81 & 82.74 & 108.42 & 98.99 & 9.43 & 60.65 & 11.80 & 19.43 \\
\hline 1973 & 272.09 & 90.75 & 117.30 & 107.25 & 10.05 & 64.04 & 12.55 & 21.10 \\
\hline 1974 & 278.99 & 94.52 & 119.20 & 108.36 & 10.84 & 65.27 & 12.61 & 20.66 \\
\hline 1975 & 299.73 & 97.11 & 137.05 & 124.49 & 12.56 & 65.57 & 14.16 & 17.58 \\
\hline 1976 & 294.37 & 96.70 & 133.72 & 120.46 & 13.26 & 63.95 & 13.96 & 14.72 \\
\hline 1977 & 320.19 & 94.21 & 150.91 & 137.24 & 13.67 & 75.07 & 15.69 & 21.38 \\
\hline 1978 & 362.41 & 101.84 & 174.52 & 160.70 & 13.82 & 86.05 & 17.28 & 26.55 \\
\hline 1979 & 403.82 & 125.89 & 191.35 & 176.97 & 14.38 & 86.58 & 18.42 & 22.02 \\
\hline 1980 & 451.78 & 135.94 & 219.20 & 199.65 & 19.55 & 96.64 & 20.50 & 21.36 \\
\hline 1981 & 486.24 & 154.56 & 225.55 & 204.84 & 20.71 & 106.13 & 21.11 & 25.57 \\
\hline 1982 & 529.47 & 176.16 & 238.30 & 216.23 & 22.07 & 115.01 & 23.67 & 19.86 \\
\hline 1983 & 593.45 & 196.08 & 264.62 & 237.56 & 27.06 & 132.75 & 26.49 & 23.14 \\
\hline 1984 & 717.10 & 229.55 & 310.57 & 278.90 & 31.67 & 176.98 & 32.71 & 41.24 \\
\hline 1985 & 896.44 & 254.16 & 386.66 & 344.87 & 41.79 & 255.62 & 40.69 & 87.84 \\
\hline 1986 & 1020.22 & 276.39 & 449.27 & 396.70 & 52.57 & 294.56 & 47.56 & 94.32 \\
\hline 1987 & 1196.25 & 320.43 & 525.16 & 458.58 & 66.58 & 350.66 & 54.49 & 115.93 \\
\hline 1988 & 1492.83 & 383.10 & 658.72 & 577.72 & 81.00 & 451.01 & 66.10 & 161.80 \\
\hline 1989 & 1690.92 & 422.80 & 727.80 & 648.40 & 79.40 & 540.32 & 78.60 & 168.70 \\
\hline 1990 & 1854.79 & 501.70 & 771.74 & 685.80 & 85.94 & 581.35 & 114.75 & 141.97 \\
\hline 1991 & 2161.78 & 528.86 & 910.22 & 808.71 & 101.51 & 722.70 & 140.97 & 208.70 \\
\hline 1992 & 2663.81 & 580.00 & 1169.95 & 1028.45 & 141.50 & 913.86 & 168.18 & 273.50 \\
\hline 1993 & 3463.44 & 688.21 & 1642.85 & 1414.38 & 228.47 & 1132.38 & 212.32 & 309.07 \\
\hline 1994 & 4675.94 & 945.72 & 2237.22 & 1935.96 & 301.26 & 1493.00 & 268.59 & 405.04 \\
\hline 1995 & 5847.81 & 1199.30 & 2853.79 & 2471.83 & 381.96 & 1794.72 & 305.47 & 493.23 \\
\hline 1996 & 6788.46 & 1384.42 & 3361.29 & 2908.26 & 453.05 & 2042.75 & 349.40 & 556.03 \\
\hline 1997 & 7446.26 & 1421.12 & 3722.27 & 3241.21 & 481.06 & 2302.87 & 379.72 & 615.99 \\
\hline
\end{tabular}




\begin{tabular}{|c|c|c|c|c|c|c|c|c|}
\hline 1998 & 7834.52 & 1455.24 & 3861.93 & 3338.79 & 523.14 & 2517.35 & 412.13 & 657.91 \\
\hline 1999 & 8206.75 & 1447.20 & 4055.78 & 3508.72 & 547.06 & 2703.77 & 446.03 & 691.03 \\
\hline 2000 & 8946.81 & 1462.82 & 4493.53 & 3904.73 & 588.80 & 2990.46 & 540.86 & 731.60 \\
\hline 2001 & 9731.48 & 1541.18 & 4875.00 & 4237.46 & 637.54 & 3315.30 & 596.83 & 791.88 \\
\hline 2002 & 10517.23 & 1611.73 & 5298.02 & 4597.52 & 700.50 & 3607.48 & 642.03 & 847.67 \\
\hline 2003 & 11739.02 & 1692.81 & 6127.41 & 5309.29 & 818.12 & 3918.80 & 664.43 & 923.84 \\
\hline 2004 & 13687.59 & 2076.81 & 7238.72 & 6281.51 & 957.21 & 4372.06 & 769.42 & 1009.85 \\
\hline \multicolumn{9}{|c|}{ B. Post-economic census data } \\
\hline 1978 & 364.52 & as & as & as & as & 88.16 & as & as \\
\hline 1979 & 406.26 & above & above & above & above & 89.02 & above & above \\
\hline 1980 & 454.56 & & & & & 99.42 & & \\
\hline 1981 & 489.16 & & & & & 109.05 & & \\
\hline 1982 & 532.34 & & & & & 117.88 & & \\
\hline 1983 & 596.27 & & & & & 135.57 & & \\
\hline 1984 & 720.81 & & & & & 180.69 & & \\
\hline 1985 & 901.60 & & & & & 260.78 & & \\
\hline 1986 & 1027.52 & & & & & 301.86 & & \\
\hline 1987 & 1205.86 & & & & & 360.27 & & \\
\hline 1988 & 1504.28 & & & & & 462.46 & & \\
\hline 1989 & 1699.23 & & & & & 548.63 & & \\
\hline 1990 & 1866.78 & & & & & 593.34 & & \\
\hline 1991 & 2178.15 & & & & & 739.07 & \multicolumn{2}{|c|}{ revised values } \\
\hline 1992 & 2692.35 & --- & revised va & ues starting & 993 & 942.40 & starting & 993 \\
\hline 1993 & 3533.39 & 688.73 & 1645.44 & 1418.80 & 226.65 & 1199.22 & 220.56 & 319.87 \\
\hline 1994 & 4819.79 & 947.14 & 2244.54 & 1948.07 & 296.47 & 1628.11 & 289.83 & 433.84 \\
\hline 1995 & 6079.37 & 1202.00 & 2867.95 & 2495.06 & 372.88 & 2009.43 & 342.41 & 546.77 \\
\hline 1996 & 7117.66 & 1388.58 & 3383.50 & 2944.76 & 438.74 & 2345.58 & 406.85 & 637.92 \\
\hline 1997 & 7897.30 & 1426.46 & 3754.30 & 3292.14 & 462.16 & 2716.54 & 459.30 & 731.41 \\
\hline 1998 & 8440.23 & 1461.80 & 3900.42 & 3401.84 & 498.58 & 3078.01 & 517.84 & 808.48 \\
\hline 1999 & 8967.71 & 1454.81 & 4103.36 & 3586.15 & 517.21 & 3409.53 & 582.18 & 878.86 \\
\hline 2000 & 9921.46 & 1471.62 & 4555.59 & 4003.36 & 552.23 & 3894.25 & 733.34 & 962.97 \\
\hline 2001 & 10965.52 & 1551.62 & 4951.23 & 4358.06 & 593.17 & 4462.67 & 840.61 & 1078.74 \\
\hline 2002 & 12033.27 & 1623.86 & 5389.68 & 4743.13 & 646.55 & 5019.73 & 939.34 & 1195.09 \\
\hline 2003 & 13582.28 & 1706.83 & 6243.63 & 5494.55 & 749.08 & 5631.81 & 1009.84 & 1348.00 \\
\hline 2004 & 15987.83 & 2095.58 & 7390.43 & 6521.00 & 869.43 & 6501.82 & 1214.76 & 1524.98 \\
\hline $2005^{\mathrm{a}}$ & 18232.06 & 2271.84 & 8620.76 & 7618.96 & 1001.80 & 7339.46 & 1380.48 & 1711.87 \\
\hline $2005^{\mathrm{b}}$ & 18308.48 & 2307.04 & 8704.67 & 7691.29 & 1013.38 & 7296.77 & 1052.61 & 1353.45 \\
\hline
\end{tabular}

A. Data for 1990-2004/05 follow GB1994, with one exception: agricultural services are included in the tertiary rather than primary sector, in contradiction to GB1984, GB1994, and GB2002. Data for 19521989 supposedly follow GB1984 (GDP 1952-95, preface p. 2), which de facto corresponds to GB1994 for the three main economic sectors (but not for the two tertiary sector subsectors), except that agricultural services are again included in the tertiary rather than primary sector. There is uncertainty about the allocation of water conservancy to the primary or tertiary sector in the years prior to 1990; since 1990, it is part of the tertiary sector, corresponding to GB1994. (See text, and notes to text, for details.)

B. Data are likely to follow GB1994 in all years through 2004 (see text for details); both rows with 2005 data presumably follow GB2002 (row “a” with preliminary data), except that in row "a” the two tertiary sector subsectors follow GB1994 and in row "b” GB2002.

Sources: 1952-77 values from GDP 1952-95, p. 27; 1978-2004 values from Statistical Yearbook 2005, p. 51 (GDP 1952-95 reports identical values for 1978-1995); benchmark revision data from Statistical Yearbook 2006, p. 57 (or for 1993-2004 from Economic Census 2004, 9 Jan. 2006, without the two tertiary sector subsectors) except for 2005 row a, which is from the Statistical Abstract 2006, pp. $20 \mathrm{f}$. 
Appendix 2. Real Growth Rates of GDP and Sectoral Value-Added, 1953-2005 (annual, in \%, pre-GB2002, pre- and post-economic census 2004)

\begin{tabular}{|c|c|c|c|c|c|c|c|c|c|c|c|}
\hline & GDP & $\begin{array}{l}\text { Pri- } \\
\text { mary } \\
\text { sector }\end{array}$ & $\begin{array}{l}\text { Secon- } \\
\text { dary } \\
\text { sector }\end{array}$ & $\begin{array}{c}\# \\
\text { In- } \\
\text { dustry }\end{array}$ & $\begin{array}{c}\# \\
\text { Con- } \\
\text { struction }\end{array}$ & $\begin{array}{c}\text { Tertiary } \\
\text { sector }\end{array}$ & $\begin{array}{l}\text { \# Trans- } \\
\text { port \& } \\
\text { commun. }\end{array}$ & $\begin{array}{l}\text { \# Com- } \\
\text { merce \& } \\
\text { catering }\end{array}$ & $\begin{array}{l}\text { GDP } \\
1952 \\
=100\end{array}$ & $\begin{array}{l}\text { GDP } \\
1978 \\
=100\end{array}$ & $\begin{array}{l}\text { GDP } \\
\text { Törn- } \\
\text { qvist }\end{array}$ \\
\hline \multicolumn{12}{|c|}{ A. Pre-economic census data } \\
\hline 1952 & & & & & & & & & 100.0 & & \\
\hline 1953 & 15.6 & 1.9 & 35.8 & 35.7 & 36.4 & 27.3 & 24.1 & 38.0 & 115.6 & & 16.0 \\
\hline 1954 & 4.2 & 1.7 & 15.7 & 19.3 & -3.3 & -0.6 & 10.8 & 1.8 & 120.5 & & 4.2 \\
\hline 1955 & 6.8 & 7.9 & 7.6 & 6.6 & 13.8 & 4.6 & 2.5 & -0.1 & 128.7 & & 6.8 \\
\hline 1956 & 15.0 & 4.7 & 34.5 & 28.6 & 70.0 & 14.1 & 21.8 & 8.5 & 148.1 & & 14.6 \\
\hline 1957 & 5.1 & 3.1 & 8.0 & 11.4 & -7.1 & 4.8 & 7.2 & -1.1 & 155.6 & & 5.0 \\
\hline 1958 & 21.3 & 0.4 & 52.9 & 53.4 & 50.0 & 17.9 & 46.7 & 3.6 & 188.6 & & 21.1 \\
\hline 1959 & 8.8 & -15.9 & 25.8 & 29.1 & 5.7 & 15.2 & 31.0 & 5.9 & 205.3 & & 8.4 \\
\hline 1960 & -0.3 & -16.4 & 5.6 & 6.1 & 1.4 & 4.8 & 10.4 & -8.8 & 204.6 & & -0.6 \\
\hline 1961 & -27.3 & 1.4 & -42.1 & -39.0 & -65.4 & -25.7 & -35.0 & -27.0 & 148.7 & & -25.9 \\
\hline 1962 & -5.6 & 4.5 & -10.8 & -13.3 & 23.8 & -9.2 & -18.9 & -4.0 & 140.4 & & -4.8 \\
\hline 1963 & 10.2 & 11.3 & 14.5 & 13.3 & 25.9 & 4.4 & -1.6 & 8.2 & 154.7 & & 10.3 \\
\hline 1964 & 18.3 & 12.9 & 25.6 & 25.6 & 25.6 & 15.5 & 5.4 & 13.2 & 182.9 & & 17.8 \\
\hline 1965 & 17.0 & 9.7 & 24.2 & 25.8 & 10.6 & 15.8 & 34.5 & -0.5 & 214.1 & & 16.3 \\
\hline 1966 & 10.7 & 7.2 & 22.4 & 23.8 & 9.4 & -1.8 & 10.3 & 20.4 & 237.1 & & 10.0 \\
\hline 1967 & -5.7 & 1.9 & -14.3 & -15.1 & -5.0 & 0.5 & -14.0 & 4.1 & 223.6 & & -4.6 \\
\hline 1968 & -4.1 & -1.6 & -9.2 & -8.2 & -18.9 & 0.6 & -2.3 & -9.3 & 214.4 & & -3.6 \\
\hline 1969 & 16.9 & 0.8 & 33.1 & 33.0 & 34.5 & 13.3 & 22.7 & 19.2 & 250.6 & & 14.1 \\
\hline 1970 & 19.4 & 7.7 & 34.8 & 35.2 & 30.4 & 7.1 & 16.8 & 9.4 & 299.3 & & 17.1 \\
\hline 1971 & 7.0 & 1.9 & 12.3 & 12.3 & 12.1 & 5.8 & 8.3 & -0.1 & 320.4 & & 7.0 \\
\hline 1972 & 3.8 & -0.9 & 6.7 & 7.6 & -2.1 & 5.0 & 9.6 & 8.8 & 332.4 & & 3.7 \\
\hline 1973 & 7.9 & 9.0 & 8.3 & 8.8 & 3.4 & 5.5 & 6.3 & 9.0 & 358.5 & & 7.9 \\
\hline 1974 & 2.3 & 4.1 & 1.4 & 1.0 & 6.2 & 1.6 & 0.3 & -2.0 & 366.8 & & 2.3 \\
\hline 1975 & 8.7 & 2.0 & 15.8 & 16.0 & 13.8 & 4.9 & 11.4 & -0.1 & 398.7 & & 8.6 \\
\hline 1976 & -1.6 & -1.8 & -2.5 & -3.1 & 4.3 & 0.4 & -1.6 & -3.7 & 392.2 & & -1.6 \\
\hline 1977 & 7.6 & -2.2 & 13.3 & 14.4 & 1.7 & 9.5 & 12.6 & 13.4 & 422.1 & & 7.4 \\
\hline 1978 & 11.7 & 4.1 & 15.0 & 16.4 & -0.6 & 13.7 & 8.9 & 23.1 & 471.4 & 100.0 & 11.5 \\
\hline 1979 & 7.6 & 6.1 & 8.2 & 8.7 & 2.0 & 7.8 & 7.7 & 8.8 & 507.1 & 107.6 & 7.5 \\
\hline 1980 & 7.8 & -1.5 & 13.6 & 12.7 & 26.7 & 5.9 & 5.7 & -1.3 & 546.8 & 116.0 & 7.1 \\
\hline 1981 & 5.2 & 7.0 & 1.9 & 1.7 & 3.2 & 10.4 & 1.9 & 30.0 & 575.5 & 122.1 & 5.3 \\
\hline 1982 & 9.1 & 11.5 & 5.6 & 5.8 & 3.4 & 13.0 & 11.7 & 3.9 & 627.6 & 133.1 & 9.1 \\
\hline 1983 & 10.9 & 8.3 & 10.4 & 9.7 & 17.1 & 15.2 & 10.0 & 21.9 & 695.8 & 147.6 & 10.7 \\
\hline 1984 & 15.2 & 12.9 & 14.5 & 14.9 & 10.9 & 19.4 & 15.0 & 21.5 & 801.3 & 170.0 & 15.1 \\
\hline 1985 & 13.5 & 1.8 & 18.6 & 18.2 & 22.2 & 18.3 & 13.5 & 28.9 & 909.2 & 192.9 & 13.2 \\
\hline 1986 & 8.8 & 3.3 & 10.2 & 9.6 & 15.9 & 12.1 & 12.8 & 10.6 & 989.7 & 210.0 & 8.8 \\
\hline 1987 & 11.6 & 4.7 & 13.7 & 13.2 & 17.9 & 14.4 & 10.0 & 13.5 & 1104.3 & 234.3 & 11.4 \\
\hline 1988 & 11.3 & 2.5 & 14.5 & 15.3 & 8.0 & 13.2 & 13.3 & 14.3 & 1228.9 & 260.7 & 10.8 \\
\hline 1989 & 4.1 & 3.1 & 3.8 & 5.1 & -8.4 & 5.4 & 4.7 & -8.3 & 1278.8 & 271.3 & 4.1 \\
\hline 1990 & 3.8 & 7.3 & 3.2 & 3.4 & 1.2 & 2.3 & 8.6 & -4.8 & 1327.9 & 281.7 & 4.0 \\
\hline 1991 & 9.2 & 2.4 & 13.9 & 14.4 & 9.6 & 8.8 & 11.2 & 4.5 & 1449.8 & 307.6 & 9.2 \\
\hline 1992 & 14.2 & 4.7 & 21.2 & 21.2 & 21.0 & 12.4 & 10.5 & 13.1 & 1656.3 & 351.4 & 14.2 \\
\hline 1993 & 13.5 & 4.7 & 19.9 & 20.1 & 18.0 & 10.7 & 12.4 & 6.6 & 1880.0 & 398.8 & 13.5 \\
\hline 1994 & 12.6 & 4.0 & 18.4 & 18.9 & 13.7 & 9.6 & 9.5 & 7.7 & 2117.8 & 449.3 & 12.5 \\
\hline
\end{tabular}




\begin{tabular}{|c|c|c|c|c|c|c|c|c|c|c|}
\hline 1995 & 10.5 & 5.0 & 13.9 & 14.0 & 12.4 & 8.4 & 12.0 & $5.9 \quad 2340.5$ & 496.5 & 10.3 \\
\hline 1996 & 9.6 & 5.1 & 12.1 & 12.5 & 8.5 & 7.9 & 11.4 & 5.4 & 544.1 & 9.4 \\
\hline 1997 & 8.8 & 3.5 & 10.5 & 11.3 & 2.6 & 9.1 & 10.8 & 8.5 & 592.2 & 8.7 \\
\hline 1998 & 7.8 & 3.5 & 8.9 & 8.9 & 9.0 & 8.3 & 10.6 & 7.7 & 638.5 & 7.7 \\
\hline 1999 & 7.1 & 2.8 & 8.1 & 8.5 & 4.3 & 7.7 & 11.3 & 7.2 & 684.1 & 7.0 \\
\hline 2000 & 8.0 & 2.4 & 9.4 & 9.8 & 5.7 & 8.1 & 11.5 & 8.2 & 738.8 & 7.7 \\
\hline 2001 & 7.5 & 2.8 & 8.4 & 8.7 & 6.8 & 8.4 & 9.5 & 7.5 & 794.2 & 7.5 \\
\hline 2002 & 8.3 & 2.9 & 9.8 & 10.0 & 8.8 & 8.7 & 7.9 & 8.1 & 860.1 & 8.3 \\
\hline 2003 & 9.5 & 2.5 & 12.7 & 12.8 & 12.1 & 7.8 & 6.3 & 9.1 & 941.8 & 9.5 \\
\hline 2004 & 9.5 & 6.3 & 11.1 & 11.5 & 8.1 & 8.3 & 14.9 & 6.3 & 1031.3 & 9.5 \\
\hline \multicolumn{11}{|c|}{ B. Post-economic census data } \\
\hline \multicolumn{11}{|c|}{ 1978-1992: GDP and all sectors as above } \\
\hline 1993 & 14.0 & 4.7 & 19.9 & 20.1 & 18.0 & 12.1 & 14.5 & 8.4 & 400.4 & 14.5 \\
\hline 1994 & 13.1 & 4.0 & 18.4 & 18.9 & 13.7 & 11.0 & 11.6 & 9.5 & 452.8 & 12.9 \\
\hline 1995 & 10.9 & 5.0 & 13.9 & 14.0 & 12.4 & 9.8 & 14.1 & 7.7 & 502.3 & 10.7 \\
\hline 1996 & 10.0 & 5.1 & 12.1 & 12.5 & 8.5 & 9.4 & 13.6 & 7.2 & 552.6 & 9.8 \\
\hline 1997 & 9.3 & 3.5 & 10.5 & 11.3 & 2.6 & 10.7 & 12.9 & 10.4 & 603.9 & 9.2 \\
\hline 1998 & 7.8 & 3.5 & 8.9 & 8.9 & 9.0 & 8.3 & 10.6 & 7.8 & 651.2 & 7.7 \\
\hline 1999 & 7.6 & 2.8 & 8.1 & 8.5 & 4.3 & 9.3 & 13.4 & 9.1 & 700.9 & 7.6 \\
\hline 2000 & 8.4 & 2.4 & 9.4 & 9.8 & 5.7 & 9.7 & 13.6 & 10.1 & 759.9 & 8.4 \\
\hline 2001 & 8.3 & 2.8 & 8.4 & 8.7 & 6.8 & 10.2 & 11.6 & 9.3 & 823.0 & 8.3 \\
\hline 2002 & 9.1 & 2.9 & 9.8 & 10.0 & 8.8 & 10.4 & 9.9 & 10.0 & 897.8 & 9.1 \\
\hline 2003 & 10.0 & 2.5 & 12.7 & 12.8 & 12.1 & 9.5 & 8.3 & 11.0 & 987.8 & 10.0 \\
\hline 2004 & 10.1 & 6.3 & 11.1 & 11.5 & 8.1 & 10.0 & 17.1 & 8.1 & 1087.4 & 10.0 \\
\hline $2005^{\mathrm{a}}$ & 9.9 & 5.2 & 11.4 & 11.4 & 11.9 & 9.6 & 11.3 & 11.4 & 1195.5 & 9.9 \\
\hline $2005^{b}$ & 10.2 & 5.2 & 11.7 & 11.6 & 12.6 & 10.0 & 11.7 & 7.8 & 1198.7 & 10.2 \\
\hline
\end{tabular}

a: Preliminary data for 2005, following GB2002 except for tertiary sector subsector values which presumably follow the GB1994.

b: First published (final) data for 2005 (no longer preliminary), following GB2002 (including the tertiary sector subsectors).

Sources: 1952-77 values from GDP 1952-95, p. 33; 1978-2004 values from Statistical Yearbook 2005, p. 53 (GDP 1952-95 reports identical values for 1978-95); benchmark revision data from Statistical Yearbook 2006, p. 59, except for 2005 row a, which is from the Statistical Abstract 2006, p. 23. Growth indices: 1952=100: GDP 1952-95, p. 36; 1978=100: Statistical Yearbook 2005, p. 54, and benchmark revision values from Statistical Yearbook 2006, p. 60, except for 2005 row a, which is from the Statistical Abstract 2006, p. 23. GDP Törnqvist index: own calculations based on primary, secondary, and tertiary sector values. 
Appendix 3. GDP and Sectoral Value-Added, 1952-2011, Nominal Values and Real Growth Rates, GB2002, Post-economic Census 2004, 2008

\begin{tabular}{|c|c|c|c|c|c|c|c|c|c|c|c|c|c|}
\hline & \multicolumn{6}{|c|}{ Nominal values (b yuan) } & \multicolumn{7}{|c|}{ Real growth rates (in \%) } \\
\hline & GDP & $\begin{array}{c}\text { Primary } \\
\text { sector }\end{array}$ & $\begin{array}{c}\text { Secondary } \\
\text { sector }\end{array}$ & \# Industry & $\begin{array}{l}\text { \# Con- } \\
\text { struction }\end{array}$ & $\begin{array}{c}\text { Tertiary } \\
\text { sector }\end{array}$ & GDP & $\begin{array}{l}\text { Prim. } \\
\text { sector }\end{array}$ & $\begin{array}{c}\text { Sec. } \\
\text { sector }\end{array}$ & $\begin{array}{l}\text { \# In- } \\
\text { dustry }\end{array}$ & $\begin{array}{l}\text { \# Con- } \\
\text { struction }\end{array}$ & $\begin{array}{l}\text { Tertiary } \\
\text { sector }\end{array}$ & $\begin{array}{c}\text { GDP } \\
\text { Törnqvist }\end{array}$ \\
\hline 1952 & 67.90 & 34.60 & 14.18 & 11.98 & 2.20 & 19.12 & & & & & & & \\
\hline 1953 & 82.42 & 38.14 & 19.25 & 16.35 & 2.90 & 25.03 & 15.6 & 1.9 & 35.8 & 35.7 & 36.4 & 24.9 & 16.1 \\
\hline 1954 & 85.94 & 39.55 & 21.17 & 18.47 & 2.70 & 25.22 & 4.2 & 1.7 & 15.7 & 19.3 & -3.3 & -0.4 & 4.4 \\
\hline 1955 & 91.08 & 42.48 & 22.22 & 19.12 & 3.10 & 26.38 & 6.8 & 7.9 & 7.6 & 6.6 & 13.8 & 4.8 & 6.9 \\
\hline 1956 & 102.90 & 44.79 & 28.07 & 22.47 & 5.60 & 30.04 & 15.0 & 4.7 & 34.5 & 28.6 & 70.0 & 13.3 & 14.9 \\
\hline 1957 & 106.93 & 43.39 & 31.70 & 27.10 & 4.60 & 31.84 & 5.1 & 3.1 & 8.0 & 11.4 & -7.1 & 4.7 & 5.0 \\
\hline 1958 & 130.82 & 44.99 & 48.35 & 41.45 & 6.90 & 37.48 & 21.3 & 0.4 & 52.9 & 53.4 & 50.0 & 18.1 & 23.1 \\
\hline 1959 & 144.04 & 38.72 & 61.55 & 53.85 & 7.70 & 43.76 & 8.8 & -15.9 & 25.8 & 29.1 & 5.7 & 15.6 & 10.0 \\
\hline 1960 & 145.75 & 34.38 & 64.82 & 56.82 & 8.00 & 46.55 & -0.3 & -16.4 & 5.6 & 6.1 & 1.4 & 5.0 & -0.2 \\
\hline 1961 & 122.09 & 44.51 & 38.89 & 36.21 & 2.68 & 38.70 & -27.3 & 1.4 & -42.1 & -39.0 & -65.4 & -25.8 & -23.8 \\
\hline 1962 & 115.12 & 45.72 & 35.93 & 32.54 & 3.39 & 33.48 & -5.6 & 4.5 & -10.8 & -13.3 & 23.8 & -9.3 & -4.5 \\
\hline 1963 & 123.64 & 50.20 & 40.76 & 36.56 & 4.20 & 32.68 & 10.2 & 11.3 & 14.5 & 13.3 & 25.9 & 4.4 & 10.4 \\
\hline 1964 & 145.55 & 56.40 & 51.35 & 46.11 & 5.24 & 37.80 & 18.3 & 12.9 & 25.6 & 25.6 & 25.6 & 15.5 & 17.9 \\
\hline 1965 & 171.72 & 65.69 & 60.22 & 54.65 & 5.57 & 45.81 & 17.0 & 9.7 & 24.2 & 25.8 & 10.6 & 15.8 & 16.4 \\
\hline 1966 & 187.31 & 70.85 & 70.95 & 64.86 & 6.09 & 45.51 & 10.7 & 7.2 & 22.4 & 23.8 & 9.4 & -1.9 & 10.4 \\
\hline 1967 & 178.03 & 72.06 & 60.28 & 54.49 & 5.79 & 45.69 & -5.7 & 1.9 & -14.3 & -15.1 & -5.0 & 0.5 & -4.3 \\
\hline 1968 & 173.02 & 73.28 & 53.73 & 49.03 & 4.70 & 46.00 & -4.1 & -1.6 & -9.2 & -8.2 & -18.9 & 0.7 & -3.5 \\
\hline 1969 & 194.58 & 74.28 & 68.91 & 62.61 & 6.30 & 51.39 & 16.9 & 0.8 & 33.1 & 33.0 & 34.5 & 13.4 & 14.9 \\
\hline 1970 & 226.13 & 80.04 & 91.22 & 82.81 & 8.41 & 54.87 & 19.4 & 7.7 & 34.8 & 35.2 & 30.4 & 7.1 & 17.8 \\
\hline 1971 & 243.53 & 83.37 & 102.28 & 92.66 & 9.62 & 57.87 & 7.0 & 1.9 & 12.3 & 12.3 & 12.1 & 5.8 & 7.1 \\
\hline 1972 & 253.02 & 83.48 & 108.42 & 98.99 & 9.43 & 61.12 & 3.8 & -0.9 & 6.7 & 7.6 & -2.1 & 5.1 & 3.8 \\
\hline 1973 & 273.34 & 91.56 & 117.30 & 107.25 & 10.05 & 64.47 & 7.9 & 9.0 & 8.3 & 8.8 & 3.4 & 5.5 & 7.9 \\
\hline 1974 & 280.37 & 95.37 & 119.20 & 108.36 & 10.84 & 65.81 & 2.3 & 4.1 & 1.4 & 1.0 & 6.2 & 1.5 & 2.3 \\
\hline 1975 & 301.31 & 97.98 & 137.05 & 124.49 & 12.56 & 66.28 & 8.7 & 2.0 & 15.8 & 16.0 & 13.8 & 4.9 & 8.7 \\
\hline 1976 & 296.15 & 97.57 & 133.72 & 120.46 & 13.26 & 64.86 & -1.6 & -1.8 & -2.5 & -3.1 & 4.3 & 0.4 & -1.6 \\
\hline 1977 & 322.11 & 95.06 & 150.91 & 137.24 & 13.67 & 76.14 & 7.6 & -2.2 & 13.3 & 14.4 & 1.7 & 9.6 & 7.6 \\
\hline 1978 & 364.52 & 102.75 & 174.52 & 160.70 & 13.82 & 87.25 & 11.7 & 4.1 & 15.0 & 16.4 & -0.6 & 13.8 & 11.6 \\
\hline 1979 & 406.26 & 127.02 & 191.35 & 176.97 & 14.38 & 87.89 & 7.6 & 6.1 & 8.2 & 8.7 & 2.0 & 7.9 & 7.5 \\
\hline 1980 & 454.56 & 137.16 & 219.20 & 199.65 & 19.55 & 98.20 & 7.8 & -1.5 & 13.6 & 12.7 & 26.7 & 6.0 & 7.3 \\
\hline
\end{tabular}




\begin{tabular}{|c|c|c|c|c|c|c|c|c|c|c|c|c|c|}
\hline 1981 & 489.16 & 155.95 & 225.55 & 204.84 & 20.71 & 107.66 & 5.2 & 7.0 & 1.9 & 1.7 & 3.2 & 10.4 & 5.3 \\
\hline 1982 & 532.34 & 177.74 & 238.30 & 216.23 & 22.07 & 116.30 & 9.1 & 11.5 & 5.6 & 5.8 & 3.4 & 13.0 & 9.1 \\
\hline 1983 & 596.27 & 197.84 & 264.62 & 237.56 & 27.06 & 133.81 & 10.9 & 8.3 & 10.4 & 9.7 & 17.1 & 15.2 & 10.8 \\
\hline 1984 & 720.81 & 231.61 & 310.57 & 278.90 & 31.67 & 178.63 & 15.2 & 12.9 & 14.5 & 14.9 & 10.9 & 19.3 & 15.1 \\
\hline 1985 & 901.60 & 256.44 & 386.66 & 344.87 & 41.79 & 258.50 & 13.5 & 1.8 & 18.6 & 18.2 & 22.2 & 18.2 & 13.4 \\
\hline 1986 & 1027.52 & 278.87 & 449.27 & 396.70 & 52.57 & 299.38 & 8.8 & 3.3 & 10.2 & 9.6 & 15.9 & 12.0 & 8.8 \\
\hline 1987 & 1205.86 & 323.30 & 525.16 & 458.58 & 66.58 & 357.40 & 11.6 & 4.7 & 13.7 & 13.2 & 17.9 & 14.4 & 11.5 \\
\hline 1988 & 1504.28 & 386.54 & 658.72 & 577.72 & 81.00 & 459.03 & 11.3 & 2.5 & 14.5 & 15.3 & 8.0 & 13.2 & 11.0 \\
\hline 1989 & 1699.23 & 426.59 & 727.80 & 648.40 & 79.40 & 544.84 & 4.1 & 3.1 & 3.8 & 5.1 & -8.4 & 5.4 & 4.1 \\
\hline 1990 & 1866.78 & 506.20 & 771.74 & 685.80 & 85.94 & 588.84 & 3.8 & 7.3 & 3.2 & 3.4 & 1.2 & 2.3 & 4.0 \\
\hline 1991 & 2178.15 & 534.22 & 910.22 & 808.71 & 101.51 & 733.71 & 9.2 & 2.4 & 13.9 & 14.4 & 9.6 & 8.9 & 9.3 \\
\hline 1992 & 2692.35 & 586.66 & 1169.95 & 1028.45 & 141.50 & 935.74 & 14.2 & 4.7 & 21.2 & 21.2 & 21.0 & 12.4 & 14.4 \\
\hline 1993 & 3533.39 & 696.38 & 1645.44 & 1418.80 & 226.65 & 1191.57 & 14.0 & 4.7 & 19.9 & 20.1 & 18.0 & 12.2 & 14.1 \\
\hline 1994 & 4819.79 & 957.27 & 2244.54 & 1948.07 & 296.47 & 1617.98 & 13.1 & 4.0 & 18.4 & 18.9 & 13.7 & 11.1 & 13.1 \\
\hline 1995 & 6079.37 & 1213.58 & 2867.95 & 2495.06 & 372.88 & 1997.85 & 10.9 & 5.0 & 13.9 & 14.0 & 12.4 & 9.8 & 10.8 \\
\hline 1996 & 7117.66 & 1401.54 & 3383.50 & 2944.76 & 438.74 & 2332.62 & 10.0 & 5.1 & 12.1 & 12.5 & 8.5 & 9.4 & 9.8 \\
\hline 1997 & 7897.30 & 1444.19 & 3754.30 & 3292.14 & 462.16 & 2698.81 & 9.3 & 3.5 & 10.5 & 11.3 & 2.6 & 10.7 & 9.2 \\
\hline 1998 & 8440.23 & 1481.76 & 3900.42 & 3401.84 & 498.58 & 3058.05 & 7.8 & 3.5 & 8.9 & 8.9 & 9.0 & 8.4 & 7.8 \\
\hline 1999 & 8967.71 & 1477.00 & 4103.36 & 3586.15 & 517.21 & 3387.34 & 7.6 & 2.8 & 8.1 & 8.5 & 4.3 & 9.3 & 7.7 \\
\hline 2000 & 9921.46 & 1494.47 & 4555.59 & 4003.36 & 552.23 & 3871.40 & 8.4 & 2.4 & 9.4 & 9.8 & 5.7 & 9.7 & 8.4 \\
\hline 2001 & 10965.52 & 1578.13 & 4951.23 & 4358.06 & 593.17 & 4436.16 & 8.3 & 2.8 & 8.4 & 8.7 & 6.8 & 10.3 & 8.3 \\
\hline 2002 & 12033.27 & 1653.70 & 5389.68 & 4743.13 & 646.55 & 4989.89 & 9.1 & 2.9 & 9.8 & 10.0 & 8.8 & 10.4 & 9.1 \\
\hline 2003 & 13582.28 & 1738.17 & 6243.63 & 5494.55 & 749.08 & 5600.47 & 10.0 & 2.5 & 12.7 & 12.8 & 12.1 & 9.5 & 10.0 \\
\hline 2004 & 15987.83 & 2141.27 & 7390.43 & 6521.00 & 869.43 & 6456.13 & 10.1 & 6.3 & 11.1 & 11.5 & 8.1 & 10.1 & 10.1 \\
\hline 2005 & 18493.74 & 2242.00 & 8759.81 & 7723.08 & 1036.73 & 7491.93 & 11.3 & 5.2 & 12.1 & 11.6 & 16.0 & 12.2 & 11.3 \\
\hline 2006 & 21631.44 & 2404.00 & 10371.95 & 9131.09 & 1240.86 & 8855.49 & 12.7 & 5.0 & 13.4 & 12.9 & 17.2 & 14.1 & 12.7 \\
\hline 2007 & 26581.03 & 2862.70 & 12583.14 & 11053.49 & 1529.65 & 11135.19 & 14.2 & 3.7 & 15.1 & 14.9 & 16.2 & 16.0 & 14.2 \\
\hline 2008 & 31404.54 & 3370.20 & 14900.34 & 13026.02 & 1874.32 & 13134.00 & 9.6 & 5.4 & 9.9 & 9.9 & 9.5 & 10.4 & 9.6 \\
\hline 2009 & 34090.28 & 3522.60 & 15763.88 & 13523.99 & 2239.88 & 14803.80 & 9.2 & 4.2 & 9.9 & 8.7 & 18.6 & 9.6 & 9.2 \\
\hline 2010 & 40151.28 & 4053.36 & 18738.32 & 16072.22 & 2666.10 & 17359.60 & 10.4 & 4.3 & 12.3 & 12.1 & 13.5 & 9.8 & 10.4 \\
\hline 2011 & 47288.16 & 4748.62 & 22041.28 & 18847.02 & 3194.27 & 20498.25 & 9.3 & 4.3 & 10.3 & 10.4 & 9.7 & 9.4 & 9.3 \\
\hline
\end{tabular}

Sources: 1952-2004: GDP 1952-2004, p. 3 (nominal values) and p. 5 (real growth rates); 2005 (or 1978)-2011: Statistical Yearbook 2012, p. 44 (nominal values) and p. 47 (real growth rates). GDP Törnqvist index (real growth rate): own calculations based on primary, secondary, and tertiary sector values. 


\section{Appendix 4. Implicit Deflators As First Published and Corresponding Real Growth Rates,}

1987-2011

\begin{tabular}{|c|c|c|c|c|c|c|c|c|}
\hline & GDP & $\begin{array}{c}\text { Primary } \\
\text { sector }\end{array}$ & $\begin{array}{l}\text { Secondary } \\
\text { sector }\end{array}$ & $\begin{array}{c}\# \\
\text { Indust. }\end{array}$ & $\begin{array}{c}\# \\
\text { Constr. }\end{array}$ & $\begin{array}{c}\text { Tertiary } \\
\text { sector }\end{array}$ & $\begin{array}{l}\text { \# Transp. } \\
\text { \& comm. }\end{array}$ & $\begin{array}{l}\text { \# Trade } \text { Törnqvist } \\
\text { \& cater. }{ }^{\mathrm{a}} \text { GDP index }\end{array}$ \\
\hline \multicolumn{9}{|c|}{$\begin{array}{l}\text { A. Implicit deflators as first published (in \%), variation of GB1994 through } 2004 \text { and GB2002 since } \\
2005\end{array}$} \\
\hline 1987 & & 10.5 & 3.8 & & & 4.9 & & \\
\hline 1988 & & 16.6 & 9.5 & & & 11.2 & & \\
\hline 1989 & & 7.0 & 7.7 & & & 13.8 & & \\
\hline 1990 & & 10.5 & 2.1 & 1.9 & 5.5 & 6.9 & 19.1 & -1.8 \\
\hline 1991 & & 3.0 & 5.3 & 4.9 & 8.1 & 3.3 & 1.1 & 2.6 \\
\hline 1992 & 5.1 & 4.4 & 5.2 & 3.9 & 15.1 & 5.5 & 0.7 & 5.4 \\
\hline 1993 & 13.6 & 10.2 & 15.3 & 13.5 & 29.4 & 13.1 & 12.1 & 14.5 \\
\hline 1994 & 16.6 & 31.8 & 10.2 & 10.0 & 13.3 & 18.0 & 14.5 & 21.0 \\
\hline 1995 & 13.0 & 20.8 & 10.3 & 10.0 & 12.8 & 13.2 & 10.0 & 15.0 \\
\hline 1996 & 7.0 & 10.2 & 5.1 & 4.6 & 9.3 & 9.0 & 2.1 & 7.0 \\
\hline 1997 & 1.2 & -2.5 & -1.3 & -1.7 & 2.7 & 8.7 & 17.0 & 4.1 \\
\hline 1998 & -1.1 & -0.7 & -4.8 & -5.3 & -2.2 & 5.3 & 22.6 & -0.4 \\
\hline 1999 & -2.4 & -3.4 & -3.2 & -3.5 & -0.3 & -0.1 & -1.0 & -3.0 \\
\hline 2000 & 0.9 & -4.1 & 2.3 & 2.6 & 1.9 & 1.9 & 0.8 & -2.5 \\
\hline 2001 & 0.0 & -2.8 & 0.5 & 0.2 & 2.2 & 0.5 & -9.3 & -0.9 \\
\hline 2002 & -0.3 & 1.6 & 0.0 & -0.2 & 1.0 & -1.4 & -2.9 & -2.8 \\
\hline 2003 & 2.0 & 3.5 & 2.6 & 2.4 & 4.2 & 0.5 & -2.2 & -0.1 \\
\hline 2004 & 6.5 & 15.4 & 6.3 & 6.1 & 8.2 & 3.0 & 0.8 & 2.8 \\
\hline $2005^{b}$ & 3.9 & 4.6 & 5.4 & 5.7 & 3.5 & 2.0 & $2.1 / 1.7$ & $0.8 / 4.1$ \\
\hline 2006 & 3.2 & 2.1 & 4.5 & 4.7 & 2.9 & 2.0 & 2.5 & 1.0 \\
\hline 2007 & 5.2 & 12.7 & 3.8 & 3.6 & 5.0 & 4.9 & 4.5 & 4.4 \\
\hline 2008 & 7.2 & 12.6 & 7.2 & 6.7 & 11.7 & 5.9 & 4.1 & 6.4 \\
\hline 2009 & -0.6 & 0.3 & -3.7 & -4.5 & 0.8 & 2.8 & 0.5 & -1.2 \\
\hline 2010 & 6.6 & 10.3 & 5.9 & 6.0 & 4.9 & 6.7 & 4.1 & 7.9 \\
\hline 2011 & 7.8 & 12.3 & 6.6 & 6.2 & 9.2 & 7.9 & 4.8 & 7.9 \\
\hline
\end{tabular}

B. Real growth rates based on implicit deflators as first published (Section A) and pre-economic

census nominal values from the Statistical Yearbook 2005 (Appendix 1), in \%

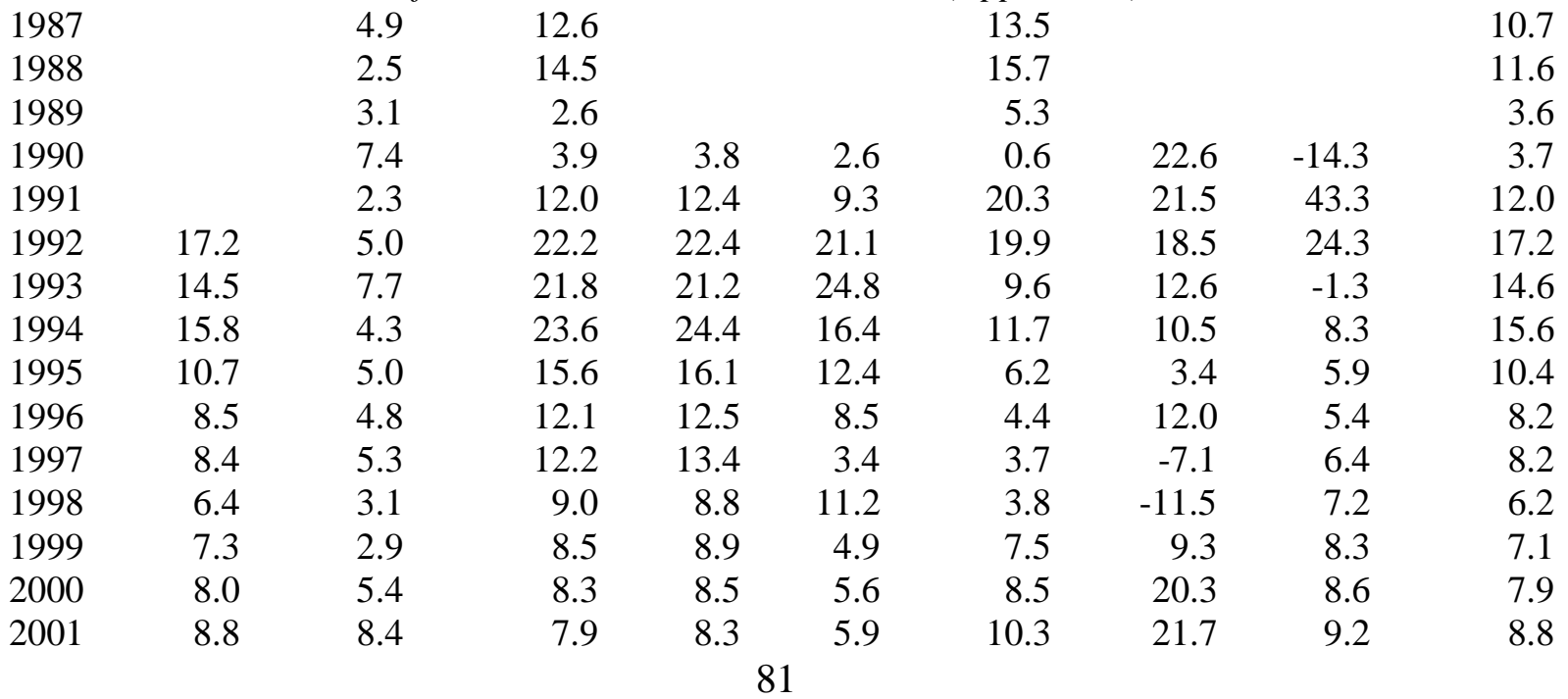




\begin{tabular}{|c|c|c|c|c|c|c|c|c|c|}
\hline 2002 & 8.4 & 2.9 & 8.7 & 8.7 & 8.8 & 10.4 & 10.8 & 10.1 & 8.3 \\
\hline 2003 & 9.4 & 1.5 & 12.7 & 12.8 & 12.1 & 8.1 & 5.8 & 9.1 & 9.4 \\
\hline 2004 & 9.5 & 6.3 & 11.1 & 11.5 & 8.1 & 8.3 & 14.9 & 6.3 & 9.5 \\
\hline \multicolumn{10}{|c|}{$\begin{array}{l}\text { C. Real growth rates based on implicit deflators as first published (above) and post-economic census } \\
\text { (pre-GB2002) nominal values (Appendix 1), in } \%^{c}\end{array}$} \\
\hline 1987 & & 4.9 & 12.6 & & & 13.8 & & & 10.8 \\
\hline 1988 & & 2.5 & 14.5 & & & 15.4 & & & 11.6 \\
\hline 1989 & & 3.1 & 2.6 & & & 4.2 & & & 3.2 \\
\hline 1990 & & 7.4 & 3.9 & 3.8 & 2.6 & 1.2 & 22.6 & -14.3 & 3.9 \\
\hline 1991 & & 2.3 & 12.0 & 12.4 & 9.3 & 20.6 & 21.5 & 43.3 & 12.1 \\
\hline 1992 & 17.6 & 5.0 & 22.2 & 22.4 & 21.1 & 20.9 & 18.5 & 24.3 & 17.6 \\
\hline 1993 & 15.5 & 7.8 & 22.0 & 21.5 & 23.8 & 12.5 & 17.0 & 2.1 & 15.6 \\
\hline 1994 & 17.0 & 4.3 & 23.8 & 24.8 & 15.5 & 15.1 & 14.8 & 12.1 & 16.8 \\
\hline 1995 & 11.6 & 5.1 & 15.8 & 16.4 & 11.5 & 9.0 & 7.4 & 9.6 & 11.4 \\
\hline 1996 & 9.4 & 4.8 & 12.3 & 12.8 & 7.7 & 7.1 & 16.4 & 9.0 & 9.0 \\
\hline 1997 & 9.6 & 5.4 & 12.4 & 13.7 & 2.6 & 6.5 & -3.5 & 10.1 & 9.1 \\
\hline 1998 & 8.1 & 3.2 & 9.1 & 9.1 & 10.3 & 7.6 & -8.0 & 11.0 & 7.5 \\
\hline 1999 & 8.9 & 3.0 & 8.7 & 9.2 & 4.0 & 10.9 & 13.6 & 12.1 & 8.5 \\
\hline 2000 & 9.6 & 5.5 & 8.5 & 8.8 & 4.8 & 12.1 & 25.0 & 12.4 & 9.4 \\
\hline 2001 & 10.5 & 8.5 & 8.1 & 8.6 & 5.1 & 14.0 & 26.4 & 13.0 & 10.5 \\
\hline 2002 & 10.1 & 3.0 & 8.9 & 9.1 & 7.9 & 14.1 & 15.1 & 14.0 & 10.1 \\
\hline 2003 & 10.7 & 1.6 & 12.9 & 13.1 & 11.2 & 11.6 & 9.9 & 12.9 & 10.8 \\
\hline 2004 & 10.5 & 6.4 & 11.4 & 11.9 & 7.3 & 12.1 & 19.3 & 10.0 & 11.0 \\
\hline
\end{tabular}

D. Real growth rates based on implicit deflators as first published (Section A), and post-economic census (2004, 2008) nominal values according to GB2002 in all years (Appendix 3 and Appendix 8)

\begin{tabular}{|c|c|c|c|c|c|c|c|c|c|}
\hline 1987 & & 4.9 & 12.6 & & & 13.8 & & & 10.9 \\
\hline 1988 & & 2.5 & 14.5 & & & 15.5 & & & 11.7 \\
\hline 1989 & & 3.1 & 2.6 & & & 4.3 & & & 3.3 \\
\hline 1990 & & 7.4 & 3.9 & 3.8 & 2.6 & 1.1 & & & 3.9 \\
\hline 1991 & & 2.5 & 12.0 & 12.4 & 9.3 & 20.6 & & & 12.4 \\
\hline 1992 & 17.6 & 5.2 & 22.2 & 22.4 & 21.1 & 20.9 & & & 17.8 \\
\hline 1993 & 15.5 & 7.7 & 22.0 & 21.5 & 23.8 & 12.6 & & & 15.8 \\
\hline 1994 & 17.0 & 4.3 & 23.8 & 24.8 & 15.5 & 15.1 & & & 17.0 \\
\hline 1995 & 11.6 & 4.9 & 15.8 & 16.4 & 11.5 & 9.1 & & & 11.4 \\
\hline 1996 & 9.4 & 4.8 & 12.3 & 12.8 & 7.7 & 7.1 & & & 9.1 \\
\hline 1997 & 9.6 & 5.7 & 12.4 & 13.7 & 2.6 & 6.4 & & & 9.1 \\
\hline 1998 & 8.1 & 3.3 & 9.1 & 9.1 & 10.3 & 7.6 & & & 7.6 \\
\hline 1999 & 8.9 & 3.2 & 8.7 & 9.2 & 4.0 & 10.9 & & & 8.6 \\
\hline 2000 & 9.6 & 5.5 & 8.5 & 8.8 & 4.8 & 12.2 & & & 9.4 \\
\hline 2001 & 10.5 & 8.6 & 8.1 & 8.6 & 5.1 & 14.0 & & & 10.6 \\
\hline 2002 & 10.1 & 3.1 & 8.9 & 9.1 & 7.9 & 14.1 & & & 10.2 \\
\hline 2003 & 10.7 & 1.6 & 12.9 & 13.1 & 11.2 & 11.7 & & & 10.9 \\
\hline 2004 & 10.5 & 6.8 & 11.4 & 11.9 & 7.3 & 11.9 & & & 11.0 \\
\hline 2005 & 11.3 & 0.1 & 12.5 & 12.0 & 15.2 & 13.8 & 12.7 & 7.7 & 11.4 \\
\hline 2006 & 13.3 & 5.0 & 13.3 & 12.9 & 16.3 & 15.9 & 11.4 & 17.2 & 13.4 \\
\hline 2007 & 16.8 & 5.7 & 16.9 & 16.8 & 17.4 & 19.9 & 14.7 & 21.3 & 16.9 \\
\hline
\end{tabular}




\begin{tabular}{rrrrrrrrrr}
2008 & 10.2 & 4.6 & 10.5 & 10.4 & 9.7 & 11.4 & 7.7 & 17.5 & 10.2 \\
2009 & 9.2 & 4.2 & 9.9 & 8.7 & 18.6 & 9.6 & 1.7 & 12.0 & 9.2 \\
2010 & 10.5 & 4.3 & 12.2 & 12.1 & 13.5 & 9.9 & 9.9 & 14.3 & 10.4 \\
2011 & 9.3 & 4.3 & 10.3 & 10.4 & 9.7 & 9.4 & 9.4 & 12.6 & 9.3 \\
\hline
\end{tabular}

a The implicit deflators of the tertiary sector and its subsectors, and therefore their real growth rates, should be treated with caution. The tertiary sector census led to revisions of the tertiary sector 1978-1993 nominal values and 1980-1993 real growth rates, the 'transport and communication' values of 1990/19911993, and the 'commerce and catering' values of 1981-1993. In addition, the subsectoral nominal values are also repeated revised. The subsectoral nominal values are also repeatedly revised. For example, the Statistical Yearbook 1999 revised the 1997 nominal 'transport and communication' value down from 452.55b to 379.72b yuan, the Statistical Yearbook 2000 the 1998 value down from 502.93b to 412.13b yuan, and the Statistical Yearbook 2002 and 2003 the 2000 and 2001 values up from 491.86 to 540.86b yuan and from 522.21b to 596.83b yuan; annual revisions to previous-year 'commerce and catering' values are on a much smaller scale. None of these revisions invalidates the earlier (and in all likelihood final) implicit deflators, but the scale of the revisions, nevertheless, gives some idea of the overall uncertainty involved in these data. The labels of the two subsectors changed from a generic label to the specific GB1994 label in the Statistical Yearbook 1996, without this affecting the data of earlier years listed in the same table. (Also see text for details on statistical breaks.)

b The GDP, primary sector, and tertiary sector implicit deflators of 2005 could be slightly inconsistent in that the nominal 2004 data follow GB1994 and the nominal 2005 data GB2002. It is unclear how the official real growth rates of 2005 were obtained; the Statistical Yearbook 2006 carries an explanatory note with the nominal data, but not with the real growth rate data.

The first set of 2005 tertiary sector subsector implicit deflators is based on the preliminary nominal values and real growth rates published in the Statistical Abstract 2006, pp. 21 and 23, following GB1994 (row 2005a in Appendix 1 as well as in Appendix 2). In contrast, in the Statistical Yearbook 2006, the first published (non-preliminary) nominal values for 2005 — but not for 2004 — follow GB2002, with a large statistical break in these two subsectors in 2005. The second set of 2005 tertiary sector subsector implicit deflators is based on nominal values from the Statistical Abstract 2006, pp. 21 (following GB1994) and real growth rates from the Statistical Yearbook 2006, p. 59 (row 2005a in Appendix 1 and row 2005b in Appendix 2). The first published (non-preliminary) real growth rates for 2005 in the Statistical Yearbook 2006 could follow either GB1994 or GB2002 - they probably follow GB2002, as the nominal data reported in this source do.

Implicit deflators for the tertiary sector subsectors in 2005 based on GB2002 could be calculated based on the data published in the Statistical Yearbook 2007, but these would then be deflators based on revised (final) nominal data and real growth rates, rather than first published implicit deflators. The 2006 and 2007 implicit deflators of the two tertiary sector subsectors correspond to GB2002; the labels of these two subsectors are now 'transport, storage and post' and 'wholesale an retail trade.'

c Nominal values are post-economic census values across all sectors (including GDP) in 1993-2004, as well as for the tertiary sector and GDP in 1987(1978)-1992. All other nominal values were not revised, and the earlier published nominal values are used in those instances.

Sources of implicit deflators (nominal values and real growth rates): Statistical Yearbook issue of each year starting with the 1988 volume (the first one to report value-added following the SNA); in each issue, the implicit deflator of one year, the most recent year in the particular issue, is obtained by dividing the growth in the nominal value (compared to the previous year) by the real growth rate (1.X/1.Y), and turning the resulting value into a percent value. For the tertiary sector subsector implicit deflators of 2005, see note "b.” The Törnqvist GDP index relies on primary, secondary, and tertiary sector values. 
Appendix 5. Tertiary Sector Nominal Value-Added and Real Growth Rates, 1952-1995 (GB1984 with adjustments)

\begin{tabular}{|c|c|c|c|c|c|c|c|c|c|}
\hline & Total & $\begin{array}{l}\text { Transport } \\
\text { \& telecom. }\end{array}$ & $\begin{array}{l}\text { Com- } \\
\text { merce }\end{array}$ & $\begin{array}{l}\text { (Social) } \\
\text { services }\end{array}$ & $\begin{array}{c}\text { Public } \\
\text { facilities }\end{array}$ & $\begin{array}{l}\text { Banking } \\
\text { \& insur. }\end{array}$ & $\begin{array}{l}\text { Real } \\
\text { estate }\end{array}$ & $\begin{array}{l}\text { Science } \\
\text { etc. }\end{array}$ & $\begin{array}{l}\text { Govern- } \\
\text { ment etc. }\end{array}$ \\
\hline \multicolumn{10}{|c|}{ A. Nominal value-added, b yuan } \\
\hline 1952 & 19.43 & 2.90 & 8.03 & 1.40 & 0.20 & 1.10 & 1.40 & 1.40 & 3.00 \\
\hline 1953 & 25.35 & 3.50 & 11.55 & 1.50 & 0.20 & 1.10 & 1.30 & 1.60 & 4.60 \\
\hline 1954 & 25.53 & 3.80 & 12.03 & 1.50 & 0.30 & 1.10 & 1.30 & 1.70 & 3.80 \\
\hline 1955 & 26.68 & 3.90 & 11.98 & 1.60 & 0.30 & 1.30 & 1.70 & 1.80 & 4.10 \\
\hline 1956 & 30.34 & 4.60 & 13.14 & 1.80 & 0.40 & 1.30 & 1.60 & 2.40 & 5.10 \\
\hline 1957 & 32.10 & 4.90 & 13.30 & 2.00 & 0.40 & 1.50 & 1.70 & 2.90 & 5.40 \\
\hline 1958 & 37.76 & 7.10 & 13.66 & 3.50 & 0.50 & 2.30 & 1.60 & 4.10 & 5.00 \\
\hline 1959 & 43.97 & 9.40 & 14.57 & 4.20 & 0.70 & 3.70 & 1.90 & 4.40 & 5.10 \\
\hline 1960 & 46.81 & 10.40 & 13.31 & 4.60 & 0.90 & 6.10 & 1.80 & 4.60 & 5.10 \\
\hline 1961 & 39.00 & 6.92 & 11.08 & 2.70 & 0.80 & 6.10 & 2.00 & 4.10 & 5.30 \\
\hline 1962 & 33.69 & 5.74 & 8.05 & 2.60 & 0.80 & 4.80 & 2.10 & 3.90 & 5.70 \\
\hline 1963 & 32.82 & 5.50 & 7.61 & 2.80 & 0.91 & 3.60 & 2.20 & 4.20 & 6.00 \\
\hline 1964 & 38.15 & 5.84 & 9.40 & 2.90 & 1.11 & 5.90 & 2.00 & 4.70 & 6.30 \\
\hline 1965 & 46.28 & 7.74 & 11.83 & 3.10 & 1.01 & 8.60 & 2.40 & 5.20 & 6.40 \\
\hline 1966 & 45.63 & 8.51 & 14.81 & 3.20 & 1.11 & 3.50 & 2.50 & 5.30 & 6.70 \\
\hline 1967 & 45.69 & 7.23 & 15.35 & 3.30 & 1.01 & 4.10 & 2.90 & 5.30 & 6.50 \\
\hline 1968 & 45.95 & 7.05 & 13.89 & 3.40 & 1.01 & 4.80 & 3.10 & 5.60 & 7.10 \\
\hline 1969 & 51.26 & 8.49 & 16.36 & 3.60 & 1.01 & 5.40 & 3.30 & 5.60 & 7.50 \\
\hline 1970 & 54.72 & 10.02 & 17.81 & 3.60 & 1.11 & 5.70 & 3.40 & 5.60 & 7.48 \\
\hline 1971 & 57.73 & 10.84 & 17.83 & 3.80 & 1.21 & 6.60 & 3.50 & 5.80 & 8.15 \\
\hline 1972 & 60.65 & 11.80 & 19.43 & 4.00 & 1.21 & 5.29 & 3.80 & 6.60 & 8.52 \\
\hline 1973 & 64.04 & 12.55 & 21.10 & 4.20 & 1.22 & 5.28 & 3.70 & 6.90 & 9.09 \\
\hline 1974 & 65.27 & 12.61 & 20.66 & 4.60 & 1.32 & 5.68 & 3.90 & 7.10 & 9.40 \\
\hline 1975 & 65.57 & 14.16 & 17.58 & 4.80 & 1.43 & 6.18 & 4.21 & 7.20 & 10.01 \\
\hline 1976 & 63.95 & 13.96 & 14.72 & 5.30 & 1.43 & 6.28 & 4.41 & 7.50 & 10.35 \\
\hline 1977 & 75.07 & 15.69 & 21.38 & 5.80 & 1.53 & 6.98 & 4.61 & 8.30 & 10.78 \\
\hline 1978 & 86.05 & 17.28 & 26.55 & 6.60 & 1.73 & 7.78 & 4.91 & 9.50 & 11.70 \\
\hline 1979 & 86.58 & 18.42 & 22.02 & 7.60 & 2.04 & 7.68 & 5.21 & 11.00 & 12.61 \\
\hline 1980 & 96.64 & 20.50 & 21.36 & 8.50 & 2.64 & 8.65 & 5.71 & 13.80 & 15.48 \\
\hline 1981 & 106.13 & 21.11 & 25.57 & 9.09 & 2.85 & 9.25 & 5.81 & 15.10 & 17.35 \\
\hline 1982 & 115.01 & 23.67 & 19.86 & 10.82 & 3.23 & 13.37 & 6.32 & 17.80 & 19.94 \\
\hline 1983 & 132.75 & 26.49 & 23.14 & 12.26 & 3.49 & 17.44 & 6.82 & 20.30 & 22.81 \\
\hline 1984 & 176.98 & 32.71 & 41.24 & 14.74 & 3.82 & 24.00 & 8.92 & 25.40 & 26.15 \\
\hline 1985 & 255.62 & 40.69 & 87.84 & 19.18 & 4.09 & 30.74 & 11.61 & 30.70 & 30.77 \\
\hline 1986 & 294.56 & 47.56 & 94.32 & 22.37 & 4.41 & 42.37 & 15.78 & 33.60 & 34.15 \\
\hline 1987 & 350.66 & 54.49 & 115.93 & 26.92 & 4.91 & 53.77 & 19.88 & 36.78 & 37.98 \\
\hline 1988 & 451.01 & 66.10 & 161.80 & 32.91 & 5.59 & 70.30 & 24.16 & 47.00 & 43.15 \\
\hline 1989 & 540.32 & 78.60 & 168.70 & 38.98 & 6.22 & 116.40 & 28.34 & 54.30 & 48.78 \\
\hline 1990 & 581.35 & 114.75 & 141.97 & 40.38 & 6.91 & 123.45 & 32.53 & 61.43 & 59.93 \\
\hline 1991 & 722.70 & 140.97 & 208.70 & 54.34 & 7.62 & 128.81 & 36.82 & 72.57 & 72.87 \\
\hline 1992 & 913.86 & 168.18 & 273.50 & 72.42 & 9.85 & 160.10 & 52.11 & 87.83 & 89.87 \\
\hline 1993 & 1132.38 & 212.32 & 309.07 & 103.35 & 14.77 & 205.70 & 64.07 & 112.44 & 110.66 \\
\hline 1994 & 1493.00 & 268.59 & 405.04 & 139.56 & 19.72 & 276.72 & 87.03 & 152.51 & 143.84 \\
\hline 1995 & 1794.72 & 305.47 & 493.23 & 179.10 & 25.40 & 348.28 & 105.86 & 175.53 & 161.85 \\
\hline
\end{tabular}




\begin{tabular}{|c|c|c|c|c|c|c|c|c|c|}
\hline \multicolumn{10}{|c|}{$\begin{array}{l}\text { B. Real growth rates (in \%) } \\
1952\end{array}$} \\
\hline 1953 & 27.3 & 24.1 & 38.0 & 3.6 & 0.0 & -2.7 & -5.0 & 10.7 & 48.7 \\
\hline 1954 & -0.6 & 10.8 & 1.8 & -2.1 & 45.0 & -1.9 & 0.0 & 4.5 & -18.8 \\
\hline 1955 & 4.6 & 2.5 & -0.1 & 5.6 & -3.4 & 17.1 & 33.8 & 4.9 & 6.9 \\
\hline 1956 & 14.1 & 21.8 & 8.5 & 12.7 & 39.3 & 0.0 & -2.2 & 34.1 & 24.0 \\
\hline 1957 & 4.8 & 7.2 & -1.1 & 8.9 & 0.0 & 15.4 & 10.3 & 19.3 & 4.6 \\
\hline 1958 & 17.9 & 46.7 & 3.6 & 74.5 & 25.0 & 50.0 & -7.6 & 40.7 & -8.0 \\
\hline 1959 & 15.2 & 31.0 & 5.9 & 18.9 & 36.0 & 60.1 & 12.7 & 6.4 & 1.2 \\
\hline 1960 & 4.8 & 10.4 & -8.8 & 6.5 & 26.5 & 60.3 & -9.0 & 1.2 & -2.8 \\
\hline 1961 & -25.7 & -35.0 & -27.0 & -49.5 & -22.1 & -13.7 & 9.9 & -22.6 & -10.2 \\
\hline 1962 & -9.2 & -18.9 & -4.0 & -7.2 & -3.0 & -24.2 & 3.4 & -7.9 & 3.6 \\
\hline 1963 & 4.4 & -1.6 & 8.2 & 14.5 & 18.5 & -21.4 & 7.1 & 14.1 & 11.6 \\
\hline 1964 & 15.5 & 5.4 & 13.2 & 7.6 & 26.0 & 71.1 & -8.2 & 15.7 & 8.9 \\
\hline 1965 & 15.8 & 34.5 & -0.5 & 9.8 & -6.2 & 50.5 & 21.1 & 13.6 & 4.3 \\
\hline 1966 & -1.8 & 10.3 & 20.4 & 3.6 & 11.0 & -59.2 & 4.6 & 2.3 & 5.0 \\
\hline 1967 & 0.5 & -14.0 & 4.1 & 3.8 & -8.9 & 17.4 & 16.7 & 0.8 & -2.3 \\
\hline 1968 & 0.6 & -2.3 & -9.3 & 3.0 & 0.0 & 16.7 & 8.6 & 5.6 & 9.3 \\
\hline 1969 & 13.3 & 22.7 & 19.2 & 7.1 & 2.2 & 14.5 & 8.0 & 1.4 & 6.8 \\
\hline 1970 & 7.1 & 16.8 & 9.4 & 0.0 & 10.6 & 6.0 & 3.5 & 0.2 & 0.1 \\
\hline 1971 & 5.8 & 8.3 & -0.1 & 6.4 & 9.9 & 17.0 & 2.1 & 4.1 & 9.6 \\
\hline 1972 & 5.0 & 9.6 & 8.8 & 5.5 & 7.4 & -19.2 & 7.2 & 13.7 & 2.9 \\
\hline 1973 & 5.5 & 6.3 & 9.0 & 4.2 & -0.8 & -2.6 & -2.4 & 4.1 & 7.8 \\
\hline 1974 & 1.6 & 0.3 & -2.0 & 9.0 & 0.8 & 7.4 & 5.5 & 2.5 & 2.6 \\
\hline 1975 & 4.9 & 11.4 & -0.1 & 4.4 & 8.4 & 9.1 & 6.8 & 1.1 & 6.3 \\
\hline 1976 & 0.4 & -1.6 & -3.7 & 10.0 & -0.7 & 1.8 & 3.4 & 3.8 & 2.6 \\
\hline 1977 & 9.5 & 12.6 & 13.4 & 7.2 & 5.0 & 9.6 & 3.8 & 8.6 & 2.1 \\
\hline 1978 & 13.7 & 8.9 & 23.1 & 13.1 & 12.2 & 9.8 & 5.7 & 13.0 & 7.7 \\
\hline 1979 & 7.8 & 7.7 & 8.8 & 12.7 & 15.1 & -2.8 & 4.1 & 14.2 & 5.4 \\
\hline 1980 & 5.9 & 5.7 & -1.3 & 1.4 & 12.0 & 6.6 & 7.9 & 19.2 & 13.7 \\
\hline 1981 & 10.4 & 1.9 & 30.0 & 3.8 & 3.0 & 4.3 & -3.5 & 6.5 & 10.7 \\
\hline 1982 & 13.0 & 11.7 & 3.9 & 17.7 & 8.8 & 44.6 & 9.1 & 15.6 & 10.4 \\
\hline 1983 & 15.2 & 10.0 & 21.9 & 11.5 & 4.1 & 27.0 & 5.2 & 12.4 & 12.6 \\
\hline 1984 & 19.4 & 15.0 & 21.5 & 15.9 & 5.2 & 31.1 & 27.7 & 22.0 & 11.1 \\
\hline 1985 & 18.3 & 13.5 & 28.9 & 21.9 & 4.9 & 16.9 & 25.0 & 12.0 & 9.2 \\
\hline 1986 & 12.1 & 12.8 & 10.6 & 8.6 & 2.4 & 31.6 & 25.9 & 1.7 & 3.9 \\
\hline 1987 & 14.4 & 10.0 & 13.5 & 18.6 & 8.0 & 23.3 & 29.3 & 7.0 & 10.0 \\
\hline 1988 & 13.2 & 13.3 & 14.3 & 11.2 & 5.3 & 19.5 & 12.7 & 10.9 & 6.7 \\
\hline 1989 & 5.4 & 4.7 & -8.3 & 2.0 & 3.0 & 25.9 & 15.9 & 6.9 & 5.1 \\
\hline 1990 & 2.3 & 8.6 & -4.8 & -0.5 & 2.0 & 1.9 & 6.2 & 3.7 & 8.0 \\
\hline 1991 & 8.8 & 11.2 & 4.5 & 25.3 & 2.5 & 2.3 & 12.0 & 10.2 & 14.5 \\
\hline 1992 & 12.4 & 10.5 & 13.1 & 18.9 & 15.0 & 8.0 & 34.7 & 8.4 & 9.6 \\
\hline 1993 & 10.7 & 12.4 & 6.6 & 15.3 & 18.9 & 10.9 & 10.8 & 13.4 & 8.7 \\
\hline 1994 & 9.6 & 9.5 & 7.7 & 10.2 & 8.3 & 9.4 & 12.0 & 13.2 & 8.5 \\
\hline 1995 & 8.4 & 12.0 & 5.9 & 6.4 & 5.8 & 8.5 & 12.4 & 7.7 & 6.3 \\
\hline
\end{tabular}

The source follows GB1984, with some adjustments (GDP 1952-95, preface p. 2). These are:

The 'farming, forestry, husbandry, fisheries and water conservancy services' are included in 'science etc.' (rather than in the primary sector, as GB1984, GB1994, and GB2002 require).

'Geological investigation and prospecting' is included in 'science etc.' 
'Real estate administration, public facilities, resident services, and consulting services' is split into 'real estate,' 'public facilities,' and (social) 'services.'

Otherwise, the individual categories stand for:

Transport \& telecom.: transport and telecommunications (jiaotong yunshu youdian tongxinye).

Commerce: Trade, public catering, material supply and marketing cooperatives, and storage.

Science etc.: Science, education, culture, health care, sports, and social welfare (plus the agricultural services as noted above, and the geological investigation and prospecting).

Government etc.: Government and Party agencies, social organizations, and others.

The 1989-90 change in the nominal values of 'transport and telecommunications' and of 'commerce' would be explained by pre-1990 values following GB1984 and the later values GB1994 (see text). The 1990 real growth rate of 'transport and telecommunications' appears plausible (i.e., to control for the statistical break), while those of 'commerce' in 1989 and 1990 appear questionable.

The 1966 real growth rate of 'banking and insurance' seems low, but applying 1965 nominal weights to tertiary sector subsector real growth rates yields approximately the official tertiary sector real growth rate (i.e., any significant changes in the 'banking and insurance' real growth rate would be inconsistent with the official tertiary sector real growth rate); the official tertiary sector real growth rate-combined with the official primary and secondary sector real growth rates-is approximately equal to the official GDP real growth rate.

Source: GDP 1952-95, pp. 27f, 33f. 
Appendix 6. Tertiary Sector Nominal Value-Added and Real Growth Rates, 1990-2003 (GB1994), Pre-Economic Census 2004

\begin{tabular}{|c|c|c|c|c|c|c|c|c|c|c|c|c|c|c|c|}
\hline & 1990 & 1991 & 1992 & 1993 & 1994 & 1995 & 1996 & 1997 & 1998 & 1999 & 2000 & 2000 & 2001 & 2002 & 2003 \\
\hline \multicolumn{16}{|c|}{ A. Nominal values (b yuan) } \\
\hline Total & 581.35 & 722.70 & 913.86 & 1132.38 & 1493.00 & 1794.72 & 2042.75 & 2302.87 & 2517.35 & 2703.77 & 2987.87 & 2990.46 & 3315.30 & 3607.49 & 3918.80 \\
\hline Agric. serv. & 4.50 & 5.36 & 6.66 & 7.65 & 10.13 & 11.58 & 12.96 & 17.73 & 19.96 & 22.19 & 22.85 & 22.85 & 26.51 & 29.85 & 31.34 \\
\hline Geol. prosp. & 6.50 & 7.68 & 9.80 & 13.45 & 19.12 & 25.33 & 28.02 & 30.23 & 30.21 & 31.62 & 32.86 & 32.86 & 34.31 & 35.68 & 34.88 \\
\hline Communic. & 114.75 & 140.97 & 168.18 & 212.32 & 268.59 & 305.47 & 349.40 & 379.72 & 412.13 & 446.03 & 540.86 & 540.86 & 596.83 & 642.03 & 664.43 \\
\hline \# Transport & 103.83 & 126.17 & 148.80 & 182.35 & 220.43 & 237.80 & 262.66 & 268.96 & 288.62 & 305.81 & 341.33 & 341.33 & 359.79 & 370.55 & 343.15 \\
\hline \# Post & 10.92 & 14.80 & 19.38 & 29.97 & 48.16 & 67.67 & 86.74 & 110.76 & 123.51 & 140.22 & 199.53 & 199.53 & 237.04 & 271.48 & 321.28 \\
\hline Trade & 141.97 & 208.70 & 273.50 & 309.07 & 405.04 & 493.23 & 556.03 & 615.99 & 657.91 & 691.03 & 731.60 & 731.60 & 791.88 & 847.67 & 923.84 \\
\hline Finance & 123.45 & 128.81 & 160.10 & 205.70 & 276.72 & 348.28 & 401.74 & 453.46 & 467.26 & 484.73 & 521.70 & 521.70 & 558.59 & 594.89 & 646.73 \\
\hline Real estate & 32.53 & 36.82 & 52.11 & 64.07 & 87.03 & 105.86 & 114.93 & 125.88 & 145.26 & 152.84 & 166.45 & 169.04 & 188.54 & 209.82 & 237.76 \\
\hline Social serv. & 32.79 & 44.73 & 59.97 & 89.92 & 120.05 & 154.64 & 171.77 & 217.79 & 264.93 & 289.37 & 324.98 & 324.98 & 385.57 & 436.64 & 487.96 \\
\hline Health & 17.40 & 21.52 & 26.40 & 33.37 & 43.38 & 48.32 & 56.42 & 61.71 & 68.72 & 74.27 & 82.61 & 82.61 & 98.63 & 106.84 & 115.88 \\
\hline Education & 39.38 & 45.49 & 54.77 & 70.99 & 97.76 & 112.45 & 135.49 & 157.32 & 182.39 & 209.80 & 239.12 & 239.12 & 276.87 & 309.05 & 341.51 \\
\hline Science & 8.15 & 9.75 & 12.50 & 15.18 & 21.34 & 27.71 & 33.57 & 43.41 & 47.08 & 55.66 & 62.61 & 62.61 & 70.27 & 80.21 & 88.42 \\
\hline Government & 54.53 & 66.21 & 80.97 & 98.64 & 127.91 & 143.80 & 161.53 & 176.39 & 196.91 & 220.12 & 234.78 & 234.78 & 258.46 & 284.45 & 313.85 \\
\hline Others & 5.40 & 6.66 & 8.90 & 12.02 & 15.93 & 18.05 & 20.89 & 23.24 & 24.59 & 26.12 & 27.45 & 27.45 & 28.84 & 30.38 & 32.20 \\
\hline \multicolumn{16}{|c|}{ B. Real growth rates (in \%) } \\
\hline Total & & 8.8 & 12.4 & 10.7 & 9.6 & 8.4 & 7.9 & 9.1 & 8.3 & 7.7 & 8.1 & 8.1 & 8.4 & 8.7 & 7.8 \\
\hline Agric. serv. & & 10.7 & 10.4 & 2.2 & 10.3 & 8.7 & 5.8 & 32.5 & 13.4 & 6.3 & 3.0 & 3.0 & 11.7 & 12.0 & 3.2 \\
\hline Geol. prosp. & & 10.9 & 15.1 & 11.2 & 16.3 & 5.4 & 5.1 & 4.3 & 0.7 & 6.2 & 4.1 & 4.1 & 3.7 & 4.8 & -3.4 \\
\hline Communic. & & 11.2 & 10.5 & 12.4 & 9.5 & 12.1 & 11.4 & 10.8 & 10.6 & 11.3 & 11.5 & 11.5 & 9.5 & 7.9 & 6.3 \\
\hline \# Transport & & 8.6 & 7.9 & 5.9 & 7.1 & 5.0 & 3.8 & 5.3 & 2.0 & 5.6 & 5.0 & 5.0 & 4.8 & 4.5 & 1.6 \\
\hline \# Post & & 35.5 & 30.3 & 53.3 & 20.1 & 39.0 & 34.0 & 23.1 & 27.4 & 20.1 & 20.4 & 20.4 & 17.5 & 12.9 & 12.9 \\
\hline Trade & & 4.5 & 13.1 & 6.6 & 7.7 & 5.9 & 5.4 & 8.5 & 7.7 & 7.2 & 8.2 & 8.2 & 7.5 & 8.1 & 9.1 \\
\hline Finance & & 2.3 & 8.0 & 10.9 & 9.4 & 8.5 & 7.5 & 8.5 & 4.9 & 4.8 & 6.5 & 6.5 & 6.4 & 6.9 & 7.0 \\
\hline Real estate & & 12.0 & 34.7 & 10.8 & 12.0 & 12.4 & 4.0 & 4.1 & 7.7 & 5.9 & 7.1 & 7.1 & 11.0 & 9.9 & 9.8 \\
\hline Social serv. & & 26.8 & 19.3 & 18.9 & 8.3 & 5.8 & 5.0 & 7.9 & 10.6 & 8.1 & 8.7 & 8.7 & 10.9 & 11.2 & 9.3 \\
\hline Health & & 14.9 & 9.4 & 11.8 & 8.2 & 6.4 & 10.3 & 8.1 & 7.8 & 4.6 & 6.3 & 6.3 & 11.6 & 9.2 & 7.2 \\
\hline Education & & 7.8 & 8.0 & 14.9 & 15.0 & 8.0 & 13.9 & 14.8 & 10.2 & 7.2 & 5.3 & 5.3 & 8.6 & 11.0 & 7.5 \\
\hline Science & & 12.0 & 15.3 & 6.9 & 17.9 & 10.5 & 14.0 & 12.1 & 10.8 & 10.5 & 6.9 & 6.9 & 7.4 & 12.1 & 7.8 \\
\hline Government & & 14.5 & 8.6 & 7.7 & 8.3 & 6.0 & 6.2 & 7.0 & 8.3 & 8.6 & 7.7 & 7.7 & 7.3 & 8.4 & 7.9 \\
\hline Others & & 14.8 & 19.5 & 17.9 & 10.6 & 8.6 & 9.5 & 10.2 & 8.1 & 6.5 & 5.6 & 5.6 & 4.4 & 5.7 & 4.5 \\
\hline Törnqvist & & 8.7 & 12.4 & 10.4 & 9.4 & 8.1 & 7.6 & 9.0 & 8.2 & 7.5 & 8.0 & 8.0 & 8.4 & 8.7 & 7.8 \\
\hline
\end{tabular}


The sectoral classification with near-certainty follows GB1994 (see text). The individual subsectors are: Agric. serv. (agricultural service): Farming, forestry, animal husbandry, and fishery services; Geol. prosp.: Geological prospecting and water conservancy; Communic.

(communications): Transport, storage, post, and telecommunications; \# Transport: \# Transport and storage; \# Post: \# Post and telecommunications; Trade: Wholesale and retail trades and catering services; Finance: Banking and insurance; Real estate; Social serv.: Social services; Health: Health care, sports and social welfare; Education: Education, culture and arts, radio, film and television; Science: Scientific research and polytechnic services; Government: Government agencies, Parties and social organizations; Others;

Törnqvist: Törnqvist index across all subsectors (not using subsector data within 'transport').

Sources: nominal values: Statistical Yearbook 1998 (first issue reporting detailed tertiary sector data), p. 59, 2005, p. 55; first column of 2000 values (with different real estate nominal value only) from 2002, p. 55; real values: Statistical Yearbook 1998, p. 61, 2005, p. 56; identical real growth rates for 2000 in 2002, p. 57. The 2000 real estate nominal value is the only tertiary sector subsector value that was ever retrospectively revised in a later published Statistical Yearbook. 
Appendix 7. Tertiary Sector Value-Added, 2004-2010 (b yuan, GB2002), Post-Economic Census 2004, 2008

\begin{tabular}{|c|c|c|c|c|c|c|c|}
\hline & 2004 & 2005 & 2006 & 2007 & 2008 & 2009 & 2010 \\
\hline Total & 6456.13 & 7491.93 & 8855.49 & 11135.19 & 13134.00 & 14803.80 & 17359.60 \\
\hline Transport, storage, and post & 930.44 & 1066.62 & 1218.30 & 1460.10 & 1636.25 & 1672.71 & 1913.22 \\
\hline Information transfer, computer services, and software services & 423.63 & 490.41 & 568.35 & 670.56 & 785.97 & 816.38 & 888.19 \\
\hline Wholesale and retail trade & 1245.38 & 1396.62 & 1653.07 & 2093.78 & 2618.23 & 2898.45 & 3574.61 \\
\hline Accommodation and catering & 366.48 & 419.57 & 479.26 & 554.81 & 661.61 & 711.82 & 806.85 \\
\hline Finance & 539.3 & 608.68 & 809.91 & 1233.75 & 1486.33 & 1776.75 & 2098.06 \\
\hline Real estate & 717.41 & 851.64 & 1037.05 & 1380.97 & 1473.87 & 1865.49 & 2278.20 \\
\hline Leasing and commercial services & 262.75 & 312.91 & 379.08 & 469.49 & 560.82 & 619.14 & 778.50 \\
\hline Scientific research, polytechnic services, and geological prosp. & 175.95 & 216.40 & 268.48 & 344.13 & 399.34 & 472.17 & 563.69 \\
\hline Administration of water, environment, and public facilities & 76.86 & 85.00 & 94.58 & 111.07 & 126.55 & 148.04 & 175.21 \\
\hline Resident and other services & 248.15 & 312.80 & 354.17 & 399.65 & 462.80 & 527.15 & 610.17 \\
\hline Education & 489.26 & 575.97 & 640.70 & 769.32 & 888.75 & 1048.18 & 1204.21 \\
\hline Health care, social insurance and social welfare & 262.07 & 298.73 & 332.62 & 401.38 & 462.87 & 508.26 & 598.08 \\
\hline Culture, sports, and entertainment & 104.32 & 120.45 & 136.27 & 163.13 & 192.24 & 223.10 & 249.58 \\
\hline Public administration and social organizations & 614.14 & 736.12 & 883.66 & 1083.04 & 1378.37 & 1516.17 & 1621.03 \\
\hline
\end{tabular}

Real growth rates are not available. Data are published with a two-year time lag.

Sources: Statistical Yearbook 2008, p. 47 (for 2004 only; GDP 1952-2004, pp. 16f., has 2004 data with a further breakdown into sub-subsectoral data), Statistical Yearbook 2010, p. 48 (with post-economic census 2008 benchmark revision data for 2005-2008), Statistical Yearbook 2012, p. 54. 
Appendix 8. Tertiary Sector Nominal Value-Added and Real Growth Rates, 1952-2011, GB2002, Post-economic Census 2004, 2008

\begin{tabular}{|c|c|c|c|c|c|c|c|c|c|c|c|c|c|c|}
\hline & \multicolumn{7}{|c|}{--- --- --- --- --- --- Nominal values (b yuan) --- --- --- --- --- --- } & \multicolumn{7}{|c|}{--- --- --- --- Real growth rates (in \%) --- --- --- --- } \\
\hline & Total & $\begin{array}{c}\text { Transport, } \\
\text { storage } \\
\text { and post }\end{array}$ & $\begin{array}{c}\text { Wholesale } \\
\text { and retail } \\
\text { trade }\end{array}$ & $\begin{array}{l}\text { Acccom- } \\
\text { modation, } \\
\text { catering }\end{array}$ & Finance & $\begin{array}{c}\text { Real } \\
\text { estate }\end{array}$ & Others & Total & $\begin{array}{c}\text { Transport, } \\
\text { storage } \\
\text { and post }\end{array}$ & $\begin{array}{c}\text { Wholesale } \\
\text { and retail } \\
\text { trade }\end{array}$ & $\begin{array}{c}\text { Acccom- } \\
\text { modation, } \\
\text { catering }\end{array}$ & Finance & $\begin{array}{c}\text { Real } \\
\text { estate }\end{array}$ & Others \\
\hline 1952 & 19.12 & 2.90 & 7.01 & 1.47 & 1.10 & 1.40 & 5.24 & & & & & & & \\
\hline 1953 & 25.03 & 3.50 & 10.24 & 1.80 & 1.09 & 1.32 & 7.07 & 24.9 & 24.1 & 40.0 & 17.6 & -2.7 & -5.0 & 22.0 \\
\hline 1954 & 25.22 & 3.80 & 10.66 & 1.86 & 1.09 & 1.35 & 6.46 & -0.4 & 10.8 & 1.7 & 1.2 & -1.9 & 0.0 & -7.1 \\
\hline 1955 & 26.38 & 3.90 & 10.49 & 2.01 & 1.28 & 1.80 & 6.90 & 4.8 & 2.5 & -1.2 & 7.9 & 17.1 & 33.8 & 6.3 \\
\hline 1956 & 30.04 & 4.60 & 11.53 & 2.19 & 1.27 & 1.72 & 8.72 & 13.3 & 21.8 & 8.7 & 8.4 & 0.0 & -2.2 & 20.2 \\
\hline 1957 & 31.84 & 4.90 & 11.61 & 2.33 & 1.46 & 1.87 & 9.66 & 4.7 & 7.2 & -1.6 & 4.5 & 15.4 & 10.3 & 7.5 \\
\hline 1958 & 37.48 & 7.10 & 12.09 & 2.70 & 2.23 & 1.79 & 11.56 & 18.1 & 46.7 & 5.0 & 16.1 & 50.0 & -7.6 & 19.2 \\
\hline 1959 & 43.76 & 9.40 & 12.93 & 3.00 & 3.57 & 2.17 & 12.69 & 15.6 & 31.0 & 6.1 & 10.1 & 60.1 & 12.7 & 8.8 \\
\hline 1960 & 46.55 & 10.40 & 12.03 & 2.77 & 5.86 & 2.09 & 13.40 & 5.0 & 10.4 & -7.1 & -9.2 & 60.3 & -9.0 & 2.6 \\
\hline 1961 & 38.70 & 6.92 & 9.64 & 2.31 & 5.83 & 2.37 & 11.63 & -25.8 & -35.0 & -29.7 & -26.8 & -13.7 & 9.9 & -24.7 \\
\hline 1962 & 33.48 & 5.74 & 6.76 & 2.14 & 4.56 & 2.53 & 11.75 & -9.3 & -18.9 & -7.5 & 9.5 & -24.2 & 3.4 & -2.6 \\
\hline 1963 & 32.68 & 5.50 & 6.45 & 2.07 & 3.40 & 2.70 & 12.55 & 4.4 & -1.6 & 9.3 & 5.9 & -21.4 & 7.1 & 13.4 \\
\hline 1964 & 37.80 & 5.84 & 8.17 & 2.17 & 5.55 & 2.50 & 13.57 & 15.5 & 5.4 & 16.1 & 0.5 & 71.1 & -8.2 & 12.1 \\
\hline 1965 & 45.81 & 7.74 & 10.46 & 2.37 & 8.05 & 3.06 & 14.12 & 15.8 & 34.5 & 1.2 & -4.1 & 50.5 & 21.1 & 7.3 \\
\hline 1966 & 45.51 & 8.51 & 13.21 & 2.64 & 3.26 & 3.25 & 14.64 & -1.9 & 10.3 & 21.5 & 9.0 & -59.2 & 4.6 & 4.2 \\
\hline 1967 & 45.69 & 7.23 & 13.86 & 2.56 & 3.80 & 3.84 & 14.40 & 0.5 & -14.0 & 5.4 & -2.5 & 17.4 & 16.7 & -0.9 \\
\hline 1968 & 46.00 & 7.05 & 12.61 & 2.38 & 4.42 & 4.18 & 15.35 & 0.7 & -2.3 & -8.8 & -7.0 & 16.7 & 8.6 & 6.7 \\
\hline 1969 & 51.39 & 8.49 & 14.90 & 2.63 & 4.95 & 4.54 & 15.88 & 13.4 & 22.7 & 19.5 & 12.0 & 14.5 & 8.0 & 4.8 \\
\hline 1970 & 54.87 & 10.02 & 16.28 & 2.69 & 5.20 & 4.76 & 15.91 & 7.1 & 16.8 & 9.8 & 2.7 & 6.0 & 3.5 & 0.6 \\
\hline 1971 & 57.87 & 10.84 & 16.25 & 2.82 & 5.99 & 4.99 & 16.99 & 5.8 & 8.3 & -0.4 & 4.7 & 17.0 & 2.1 & 7.6 \\
\hline 1972 & 61.12 & 12.29 & 17.66 & 3.07 & 4.78 & 5.52 & 17.80 & 5.1 & 15.1 & 8.5 & 8.7 & -19.2 & 7.2 & 4.0 \\
\hline 1973 & 64.47 & 13.10 & 19.20 & 3.26 & 4.75 & 5.48 & 18.69 & 5.5 & 6.3 & 9.2 & 6.6 & -2.6 & -2.4 & 5.1 \\
\hline 1974 & 65.81 & 13.22 & 18.82 & 3.34 & 5.08 & 5.89 & 19.47 & 1.5 & 0.7 & -2.0 & 1.9 & 7.4 & 5.5 & 3.2 \\
\hline 1975 & 66.28 & 14.83 & 16.02 & 3.12 & 5.50 & 6.47 & 20.34 & 4.9 & 11.2 & -0.1 & 1.6 & 9.1 & 6.8 & 4.4 \\
\hline 1976 & 64.86 & 14.71 & 13.44 & 3.00 & 5.56 & 6.91 & 21.25 & 0.4 & -1.2 & -3.5 & 1.4 & 1.8 & 3.4 & 4.0 \\
\hline 1977 & 76.14 & 16.52 & 19.51 & 3.75 & 6.15 & 7.36 & 22.85 & 9.6 & 12.4 & 13.4 & 10.5 & 9.6 & 3.8 & 5.4 \\
\hline 1978 & 87.25 & 18.20 & 24.23 & 4.46 & 6.82 & 7.99 & 25.56 & 13.8 & 8.9 & 23.1 & 18.1 & 9.8 & 5.7 & 11.0 \\
\hline
\end{tabular}




\begin{tabular}{|c|c|c|c|c|c|c|c|c|c|c|c|c|c|c|}
\hline 1979 & 87.89 & 19.37 & 20.09 & 4.40 & 6.69 & 8.63 & 28.71 & 7.9 & 8.3 & 8.7 & 11.1 & -2.8 & 4.1 & 10.1 \\
\hline 1980 & 98.20 & 21.34 & 19.38 & 4.74 & 7.50 & 9.64 & 35.60 & 6.0 & 4.3 & -1.9 & 3.9 & 6.6 & 7.9 & 15.1 \\
\hline 1981 & 107.66 & 22.07 & 23.11 & 5.41 & 7.98 & 9.99 & 39.09 & 10.4 & 1.9 & 29.5 & 17.5 & 4.3 & -3.5 & 7.6 \\
\hline 1982 & 116.30 & 24.69 & 17.14 & 6.23 & 11.48 & 11.08 & 45.68 & 13.0 & 11.4 & -0.7 & 31.6 & 44.6 & 9.1 & 13.6 \\
\hline 1984 & 178.63 & 33.85 & 36.35 & 9.68 & 20.39 & 16.23 & 62.12 & 19.3 & 14.9 & 24.7 & 8.1 & 31.1 & 27.7 & 15.5 \\
\hline 1985 & 258.50 & 42.17 & 80.24 & 13.83 & 25.99 & 21.52 & 74.75 & 18.2 & 13.8 & 33.5 & 6.3 & 16.9 & 25.0 & 11.7 \\
\hline 1986 & 299.38 & 49.88 & 85.26 & 16.32 & 35.64 & 29.81 & 82.46 & 12.0 & 13.9 & 9.4 & 15.6 & 31.6 & 25.9 & 3.0 \\
\hline 1989 & 544.84 & 81.27 & 153.62 & 27.74 & 96.43 & 56.62 & 129.16 & 5.4 & 4.2 & -10.7 & 9.9 & 25.9 & 15.9 & 4.9 \\
\hline 1990 & 588.84 & 116.70 & 126.89 & 30.19 & 101.75 & 66.22 & 147.09 & 2.3 & 8.3 & -5.3 & 3.5 & 1.9 & 6.2 & 3.7 \\
\hline 1991 & 733.71 & 142.03 & 183.46 & 44.23 & 105.63 & 76.37 & 181.99 & 8.9 & 10.6 & 5.2 & 8.2 & 2.3 & 12.0 & 15.7 \\
\hline 1992 & 935.74 & 168.90 & 240.50 & 58.46 & 130.62 & 110.13 & 227.13 & 12.4 & 10.1 & 10.5 & 27.0 & 8.0 & 34.7 & 11.5 \\
\hline 1993 & 1191.57 & 217.40 & 281.66 & 71.21 & 166.97 & 137.96 & 316.37 & 12.2 & 12.5 & 8.6 & 8.2 & 10.9 & 10.8 & 16.9 \\
\hline 1994 & 1617.98 & 278.79 & 377.34 & 100.85 & 223.48 & 190.93 & 446.58 & 11.1 & 8.5 & 8.2 & 27.1 & 9.4 & 12.0 & 12.7 \\
\hline 1999 & 3387.34 & 517.52 & 749.11 & 194.12 & 381.65 & 368.18 & 1176.77 & 9.3 & 12.2 & 8.7 & 7.7 & 4.8 & 5.9 & 11.4 \\
\hline 2000 & 3871.40 & 616.10 & 815.86 & 214.63 & 408.67 & 414.91 & 1401.24 & 9.7 & 8.6 & 9.4 & 9.3 & 6.5 & 7.1 & 13.0 \\
\hline 2001 & 4436.16 & 687.03 & 911.94 & 240.01 & 435.35 & 471.51 & 1690.33 & 10.3 & 8.8 & 9.1 & 7.6 & 6.4 & 11.0 & 12.9 \\
\hline 2002 & 4989.89 & 749.29 & 999.54 & 272.48 & 461.28 & 534.64 & 1972.67 & 10.4 & 7.1 & 8.8 & 12.1 & 6.9 & 9.9 & 13.6 \\
\hline 2003 & 5600.47 & 791.32 & 1116.95 & 312.61 & 498.94 & 617.27 & 2263.39 & 9.5 & 6.1 & 9.9 & 12.4 & 7.0 & 9.8 & 10.8 \\
\hline 2004 & 6456.13 & 930.44 & 1245.38 & 366.48 & 539.30 & 717.41 & 2657.12 & 10.1 & 14.5 & 6.6 & 12.3 & 3.7 & 5.9 & 12.6 \\
\hline 2005 & 7491.93 & 1066.62 & 1396.62 & 419.57 & 608.68 & 851.64 & 3148.80 & 12.2 & 11.2 & 13.0 & 12.3 & 13.8 & 12.2 & 11.9 \\
\hline 2006 & 8855.49 & 1218.30 & 1653.07 & 479.26 & 809.91 & 1037.05 & 3657.91 & 14.1 & 10.0 & 19.5 & 12.6 & 25.9 & 15.5 & 10.8 \\
\hline 2007 & 11135.19 & 1460.10 & 2093.78 & 554.81 & 1233.75 & 1380.97 & 4411.77 & 16.0 & 11.8 & 20.2 & 9.6 & 27.6 & 24.4 & 11.3 \\
\hline 2008 & 13134.00 & 1636.25 & 2618.23 & 661.61 & 1486.33 & 1473.87 & 5257.71 & 10.4 & 7.3 & 15.9 & 9.6 & 13.3 & 1.0 & 11.0 \\
\hline 2009 & 14803.80 & 1672.71 & 2898.45 & 711.82 & 1776.75 & 1865.49 & 5878.59 & 9.6 & 4.2 & 12.1 & 5.5 & 18.2 & 11.3 & 7.8 \\
\hline 2010 & 17359.60 & 1913.22 & 3574.61 & 806.85 & 2098.06 & 2278.20 & 6688.66 & 9.8 & 9.8 & 14.3 & 10.0 & 10.0 & 7.0 & 7.9 \\
\hline 2011 & 20498.25 & 2193.19 & 4344.52 & 917.28 & 2495.83 & 2670.80 & 7876.63 & 9.4 & 9.4 & 12.6 & 6.6 & 7.2 & 6.7 & 9.6 \\
\hline
\end{tabular}

Sources: GDP 1952-2004, pp. 8 and 10; Statistical Yearbook 2012, pp. 49 and 52 (for the years since 1978). 
Appendix 9. Directly Reporting Industrial Enterprise Output Measures 1993-2002 (b yuan)

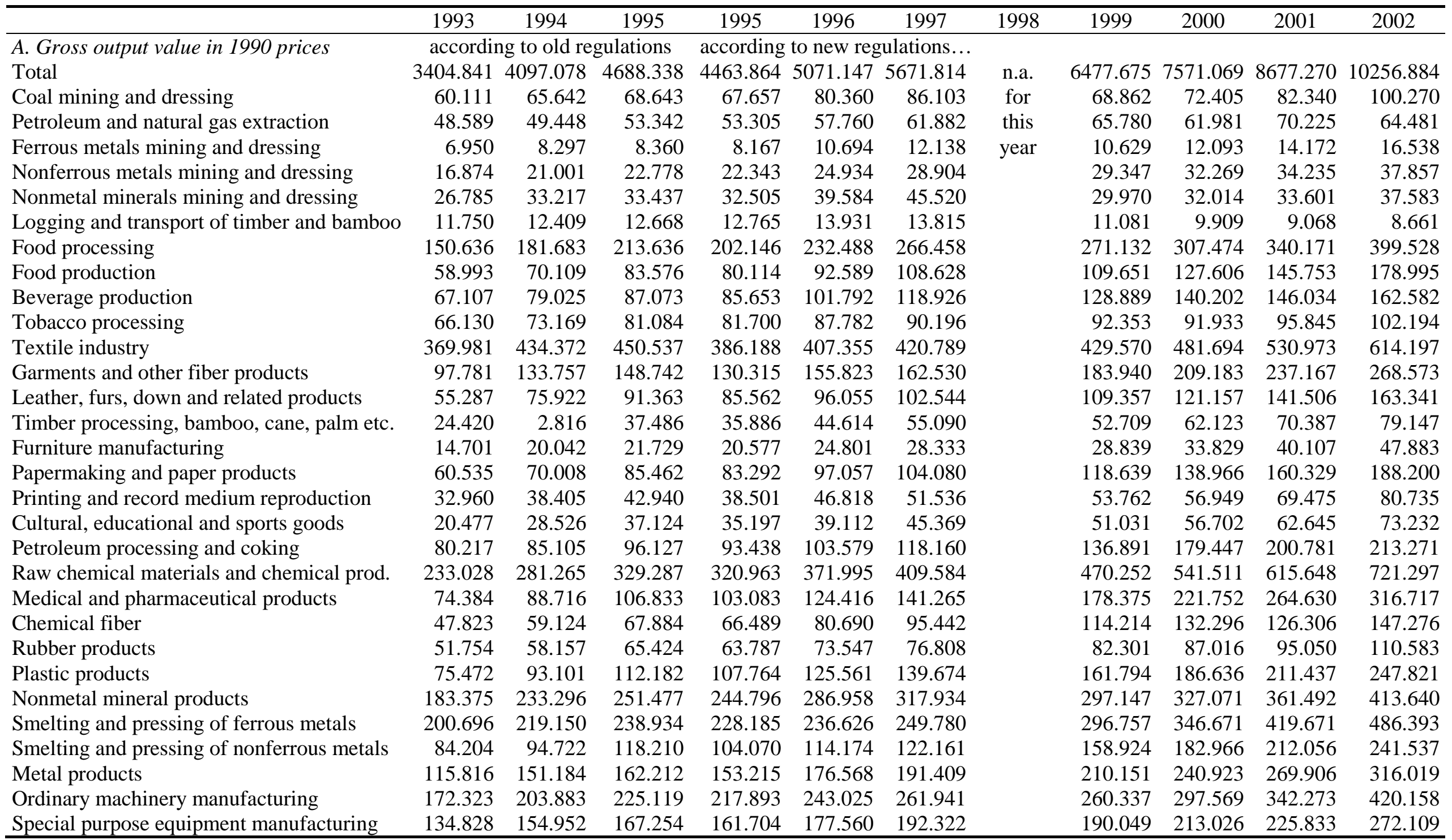




\begin{tabular}{|c|c|c|c|c|c|c|c|c|c|c|c|}
\hline Transport equipment manufacturing & 219.104 & 259.656 & 311.244 & 304.306 & 349.788 & 395.624 & & 471.274 & 550.588 & 673.056 & 886.589 \\
\hline Electric equipment and machinery & 180.958 & 222.873 & 275.194 & 266.211 & 305.659 & 344.255 & & 427.132 & 522.861 & 608.841 & 699.067 \\
\hline Electronic and telecommunications equipm. & 154.094 & 221.839 & 317.249 & 307.781 & 363.864 & 492.330 & & 818.888 & 1079.125 & 1316 & 1638.980 \\
\hline Instruments, meters, cultural and off. mach. & 36.770 & 41.832 & 44.952 & 44.836 & 52.466 & 64.245 & & 74.160 & 89.909 & & 007 \\
\hline Prod./supply of electric power, steam etc. & 86.320 & 97.097 & 108.351 & 108.597 & 116.877 & 131.547 & & 153.395 & 187.577 & 56 & 435 \\
\hline Production and supply of gas & 4.316 & 4.560 & 7.337 & 4.298 & 5.090 & 5.497 & & 8.645 & 11.106 & 11.986 & 14.196 \\
\hline Production and supply of tap water & 7.667 & 8.619 & 9.477 & 9.356 & 10.852 & 11.547 & & 11.003 & 11.412 & 11.164 & 12.490 \\
\hline Other extraction & 0.232 & & & & & & & & & & \\
\hline Implicit residual & 13.979 & 47.740 & 93.611 & 91.219 & 98.303 & 107.448 & & 110.445 & 113.118 & 124.620 & 138.302 \\
\hline B. Gross output value in $c$ & accor & 15 to vid & ns & tectum & & ,... & & & & & \\
\hline Total & 3969.300 & 5135.303 & 6424.671 & 5494.686 & 6274.016 & 6835.268 & & 7270.704 & 8567.366 & 398 & 1077.648 \\
\hline Coal mining and dressing & 83.019 & 103.648 & 27.619 & 115.516 & 42.882 & 153.863 & & 123.597 & 127.681 & 153.128 & 198.076 \\
\hline Petroleum and natural gas extraction & 96.809 & 136.039 & 165.294 & 142.846 & 163.929 & 187.510 & & 208.489 & 213.011 & 278.005 & 275.659 \\
\hline Ferrous metals mining and dressing & 8.553 & & 12.428 & 11.193 & 14.578 & 16.538 & & 14.713 & 16.486 & & 22.546 \\
\hline etals mining and dressi & 19.126 & & & & 34.783 & & & & & & 46.390 \\
\hline Logging and transport of timber and bamboo & 15.192 & .750 & 17.027 & 16.493 & 17.766 & 17.485 & & 13.626 & 12.109 & 11.212 & 11.163 \\
\hline Food processing & 172.683 & 250.901 & 348.442 & 304.510 & 347.162 & 379.247 & & 351.700 & 372.270 & 409 & 477.696 \\
\hline Food production & 62.989 & 82.607 & 112.859 & 99.507 & 115.409 & 0.255 & & 19 & 144.252 & 162. & 196.731 \\
\hline Beverage production & & & 2.035 & & 2.277 & 61.960 & & 70 & 37 & 182.434 & 199.626 \\
\hline Tobacco processing & 76.610 & 6.885 & 5.106 & & 20.219 & 29.603 & & 77 & 145.129 & 169.472 & 203.749 \\
\hline Textile industry & 352.074 & 494.993 & 00.508 & 460.400 & 472.229 & 476.028 & & 452.982 & 514.930 & 562 & 637.079 \\
\hline Garments and other fiber products & 99.358 & 144.148 & 180.666 & 147.015 & 177.666 & 184.528 & & 59 & 116 & 26 & 291.491 \\
\hline , down and related products & 57.073 & 84.341 & 112.391 & 97.441 & 111.220 & 118.636 & & 93 & 517 & 157 & 180.146 \\
\hline ocessing, bamboo, & 27.861 & 36.642 & 46.226 & 40.553 & 51.324 & 62.636 & & 56.058 & 65.677 & 74.122 & 82.806 \\
\hline Furniture manufacturing & 15.364 & 21.878 & 26.002 & 22.603 & 28.165 & 32.020 & & 31.838 & 37.018 & 43.485 & 52.421 \\
\hline Papermaking and paper prod & 1.122 & 75.870 & 116.287 & 101.446 & 121.533 & 124.443 & & 132.773 & 159.036 & 180.428 & 208.154 \\
\hline $\mathrm{d}$ record medium re & 33.852 & 40.459 & 50.843 & 41.159 & 53.147 & 57.441 & & 57.876 & 61.671 & 72. & 82.556 \\
\hline Cultural, educational and spo & 20.833 & 30.007 & 42.651 & 37.106 & 43.124 & 49.022 & & 55.574 & 61.794 & 68.072 & 78.208 \\
\hline ocessing and coking & 144.610 & 188.037 & 238.503 & 202.812 & 221.210 & 256.900 & & 270.558 & 442.919 & 458.776 & 478.498 \\
\hline Raw chemical materials and chemical prod. & 237.700 & 316.533 & 435.533 & 381.979 & 447.136 & 472.237 & & 492.478 & 574.902 & 630.366 & 722.005 \\
\hline Rubber products & 44.795 & 55.013 & 72.792 & 61.988 & 74.920 & 78.177 & & 78.030 & 81.270 & 89.382 & 106.460 \\
\hline Plastic products & 71.200 & 92.664 & 130.965 & 112.765 & 133.793 & 144.247 & 149.783 & 162.341 & 189.970 & 213.660 & 248.792 \\
\hline
\end{tabular}




\begin{tabular}{|c|c|c|c|c|c|c|c|c|c|c|c|}
\hline Nonmetal mineral products & 233.292 & 299.715 & 342.906 & 301.836 & 355.969 & 382.753 & 320.448 & 339.464 & 369.285 & 402.602 & 455.704 \\
\hline Smelting and pressing of ferrous metals & 393.118 & 416.542 & 436.052 & 366.022 & 374.584 & 385.632 & 388.319 & 409.736 & 473.290 & 570.731 & 649.236 \\
\hline Smelting and pressing of nonferrous metals & 97.445 & 120.236 & 178.672 & 137.229 & 142.455 & 147.000 & 162.873 & 179.314 & 218.023 & 236.917 & 259.998 \\
\hline Metal products & 130.205 & 170.799 & 192.764 & 165.072 & 194.378 & 207.810 & 215.068 & 221.509 & 253.976 & 285.227 & 329.438 \\
\hline Ordinary machinery manufacturing & 196.555 & 239.175 & 274.708 & 236.569 & 268.092 & 281.335 & 257.980 & 269.390 & 304.695 & 350.533 & 424.796 \\
\hline Special purpose equipment manufacturing & 149.933 & 179.190 & 204.081 & 175.654 & 198.814 & 207.102 & 192.027 & 198.071 & 219.263 & 235.225 & 281.890 \\
\hline Transport equipment manufacturing & 259.928 & 318.580 & 380.995 & 330.328 & 378.501 & 412.310 & 421.201 & 465.931 & 536.483 & 647.495 & 835.927 \\
\hline Electric equipment and machinery & 185.093 & 232.704 & 302.493 & 259.430 & 305.976 & 336.609 & 362.858 & 402.155 & 483.468 & 548.107 & 614.200 \\
\hline Electronic and telecommunications equipm. & 129.912 & 199.986 & 281.568 & 253.048 & 305.109 & 392.103 & 489.356 & 583.096 & 754.958 & 899.025 & 1128.864 \\
\hline Instruments, meters, cultural and off. mach. & 36.574 & 42.445 & 48.033 & 42.570 & 52.873 & 59.995 & 69.275 & 70.573 & 86.791 & 93.767 & 108.962 \\
\hline Prod./supply of electric power, steam etc. & 144.551 & 201.761 & 275.406 & 244.055 & 280.544 & 332.007 & 361.681 & 399.691 & 461.139 & 508.770 & 588.905 \\
\hline Production and supply of gas & 5.284 & 6.307 & 7.929 & 7.616 & 8.059 & 9.584 & 10.325 & 13.127 & 17.030 & 18.487 & 22.460 \\
\hline Production and supply of tap water & 11.413 & 15.250 & 19.697 & 18.244 & 23.234 & 27.008 & 26.969 & 31.495 & 32.553 & 34.448 & 37.757 \\
\hline Other extraction & 0.192 & & & & & & & & & & \\
\hline Other manufacturing & 58.110 & 75.323 & & & & & & & & & \\
\hline Implicit residual & 17.882 & 22.074 & 112.548 & 97.861 & 109.187 & 116.708 & 105.970 & 112.133 & 118.743 & 132.111 & 147.312 \\
\hline \multicolumn{12}{|l|}{ C. Value-added in current prices } \\
\hline Total & 1284.263 & 470.006 & same & 544.613 & 1802.611 & 983.518 & 942.193 & 156.474 & 539.480 & 2832.937 & 3299.475 \\
\hline Coal mining and dressing & 38.598 & 43.816 & as on & 59.863 & 68.490 & 71.210 & 60.155 & 56.502 & 58.309 & 69.865 & 91.906 \\
\hline Petroleum and natural gas extraction & 56.514 & 75.120 & right & 93.932 & 99.281 & 115.587 & 118.641 & 143.845 & 220.902 & 201.879 & 193.705 \\
\hline Ferrous metals mining and dressing & 3.685 & 4.020 & & 4.106 & 5.636 & 5.877 & 5.421 & 5.304 & 6.231 & 7.228 & 8.625 \\
\hline ng and dressing & 7.916 & 8.949 & & 11.355 & 12.101 & 13.311 & 11.127 & 12.605 & 13.977 & 14.178 & 15.080 \\
\hline Nonmetal minerals $\mathrm{m}$ & 13.516 & 13.532 & & 13.392 & 16.472 & 17.887 & 11.074 & 11.836 & 12.264 & 12.542 & 14.248 \\
\hline Logging and transport of timber and bamboo & 8.598 & 8.408 & & 9.080 & 8.985 & 8.757 & 8.236 & 6.650 & 6.149 & 5.541 & 5.571 \\
\hline Food processing & 49.560 & 61.611 & & 49.675 & 71.218 & 78.099 & 68.154 & 76.186 & 83.529 & 94.470 & 111.269 \\
\hline Food production & 18.737 & 21.796 & & 21.112 & 29.007 & 35.255 & 32.495 & 34.455 & 41.581 & 45.187 & 55.301 \\
\hline Beverage production & 27.773 & 33.043 & & 35.360 & 45.741 & 55.708 & 54.361 & 58.578 & 61.890 & 64.256 & 70.964 \\
\hline Tobacco processing & 42.192 & 55.250 & & 61.260 & 75.743 & 82.318 & 88.616 & 89.205 & 93.580 & 109.307 & 135.963 \\
\hline Textile industry & 95.086 & 111.731 & & 89.845 & 103.996 & 111.667 & 101.730 & 111.712 & 127.284 & 138.752 & 156.910 \\
\hline Garments and other fiber products & 32.523 & 35.512 & & 34.729 & 44.706 & 46.379 & 48.193 & 50.597 & 59.202 & 68.812 & 74.608 \\
\hline Leather, furs, down and related products & 15.181 & 20.226 & & 20.147 & 27.845 & 29.078 & 27.325 & 28.361 & 32.362 & 39.176 & 45.796 \\
\hline Timber processing, bamboo, cane, palm etc. & 9.535 & 9.953 & & 9.508 & 14.333 & 16.997 & 11.257 & 13.289 & 15.753 & 19.291 & 21.392 \\
\hline Furniture manufacturing & 4.829 & 5.874 & & 5.643 & 7.958 & 8.897 & 7.666 & 7.796 & 9.486 & 11.758 & 13.934 \\
\hline Papermaking and paper products & 15.106 & 19.182 & & 23.235 & 32.921 & 33.889 & 31.892 & 35.556 & 41.262 & 47.487 & 57.088 \\
\hline Printing and record medium reproduction & 12.388 & 12.440 & & 12.317 & 17.017 & 18.757 & 18.271 & 19.794 & 20.139 & 24.398 & 27.953 \\
\hline Cultural, educational and sports goods & 6.527 & 7.831 & & 9.118 & 12.120 & 13.076 & 14.114 & 14.020 & 15.530 & 17.987 & 20.452 \\
\hline
\end{tabular}




\begin{tabular}{|c|c|c|c|c|c|c|c|c|c|c|}
\hline Petroleum processing and coking & 34.583 & 43.415 & 56.133 & 55.947 & 60.247 & 52.858 & 59.024 & 78.799 & 88.330 & 100.392 \\
\hline Raw chemical materials and chemical prod. & 68.359 & 79.280 & 94.272 & 118.862 & 118.985 & 110.344 & 121.688 & 141.581 & 160.127 & 186.264 \\
\hline Medical and pharmaceutical products & 22.868 & 25.155 & 26.467 & 35.693 & 41.151 & 43.291 & 51.486 & 63.388 & 72.243 & 83.465 \\
\hline Chemical fiber & 14.582 & 17.159 & 20.299 & 19.497 & 20.952 & 18.462 & 25.255 & 29.578 & 22.210 & 24.892 \\
\hline Rubber products & 12.563 & 13.835 & 13.837 & 18.846 & 20.967 & 20.310 & 20.261 & 21.898 & 24.829 & 29.255 \\
\hline Plastic products & 20.864 & 22.168 & 22.506 & 32.438 & 35.810 & 35.428 & 38.780 & 46.443 & 54.502 & 64.684 \\
\hline Nonmetal mineral products & 89.782 & 94.212 & 89.991 & 105.520 & 110.677 & 90.914 & 100.460 & 112.672 & 121.188 & 136.516 \\
\hline Smelting and pressing of ferrous metals & 128.507 & 129.037 & 105.324 & 99.876 & 102.541 & 98.266 & 108.115 & 129.929 & 153.015 & 179.949 \\
\hline Smelting and pressing of nonferrous metals & 26.087 & 26.346 & 30.209 & 30.653 & 31.125 & 33.233 & 40.504 & 51.269 & 59.118 & 62.614 \\
\hline Metal products & 39.839 & 44.008 & 38.394 & 49.086 & 51.671 & 50.429 & 54.072 & 60.946 & 71.328 & 84.123 \\
\hline Ordinary machinery manufacturing & 61.297 & 68.333 & 66.977 & 72.669 & 79.480 & 69.694 & 74.361 & 84.075 & 97.163 & 115.303 \\
\hline Special purpose equipment manufacturing & 43.585 & 49.088 & 44.939 & 52.027 & 54.535 & 48.540 & 51.573 & 58.097 & 63.688 & 78.175 \\
\hline Transport equipment manufacturing & 69.795 & 75.536 & 80.512 & 92.881 & 100.592 & 108.028 & 119.314 & 132.361 & 163.369 & 217.717 \\
\hline Electric equipment and machinery & 53.058 & 58.170 & 60.382 & 74.098 & 81.962 & 87.957 & 100.257 & 123.150 & 137.844 & 158.473 \\
\hline Electronic and telecommunications equipm. & 35.514 & 48.427 & 63.500 & 66.331 & 90.237 & 112.096 & 134.795 & 182.431 & 203.503 & 252.092 \\
\hline Instruments, meters, cultural and off. mach. & 12.226 & 12.917 & 12.255 & 14.430 & 14.861 & 16.847 & 18.046 & 21.436 & 23.790 & 26.854 \\
\hline Prod./supply of electric power, steam etc. & 62.790 & 81.870 & 122.109 & 131.728 & 162.710 & 187.519 & 216.182 & 232.862 & 269.630 & 316.574 \\
\hline Production and supply of gas & 0.887 & 0.345 & 0.312 & -1.150 & 1.065 & 1.413 & 3.664 & 3.474 & 4.614 & 5.310 \\
\hline Production and supply of tap water & 5.434 & 6.436 & 8.382 & 10.040 & 11.314 & 12.386 & 14.632 & 15.088 & 16.196 & 17.098 \\
\hline Other extraction & 0.056 & & & & & & & & & \\
\hline Other manufacturing & 19.459 & 20.498 & & & & & & & & \\
\hline Implicit residual & 3.864 & 5.477 & 24.136 & 29.569 & 29.887 & 25.450 & 27.714 & 30.573 & 34.136 & 38.960 \\
\hline
\end{tabular}

Abbreviations: Raw chemical materials and chemical prod.: Raw chemical materials and chemical products; Electronic and telecommunications equipm.: Electronic and telecommunications equipment; Timber processing, bamboo, cane, palm etc.: Timber processing, bamboo, cane, palm fiber and straw products; Instruments, meters, cultural and off. mach.: Instruments, meters, cultural and office machinery; Prod./supply of electric power, steam etc.: Production and supply of electric power, steam and hot water.

GOV of 2000 in current prices in the sector "petroleum and natural gas extraction” was adjusted down by 100b yuan (to the value reported in the table) in order for the series of this sector to be consistent over time and in order for the implicit residual to be consistent over time.

The definition of the directly reporting industrial enterprises changed in 1998, from the previous "all industrial enterprises with independent accounting systems at the township level and above" to "all industrial SOSCEs plus all industrial non-SOSCEs with independent accounting systems and annual sales revenue in excess of $5 \mathrm{~m}$ yuan.”

Sources: Industrial Yearbook 1994, numerous pages; 1995, numerous pages; 1998, p. 77 (for 1996 and 1997 data); 2001 , p. 49 (for 1999 and 2000 data); 2002, p. 68; 2003, p. 68; Industrial Census 1995, numerous pages (for 1995 data); Statistical Yearbook 1999, p. 432 (for 1998 data). 
Appendix 10. Directly Reporting Industrial Enterprise Value-added 2003-2007 (b yuan)

\begin{tabular}{|c|c|c|c|c|c|}
\hline & 2003 & $2004^{\mathrm{a}}$ & 2005 & 2006 & 2007 \\
\hline Total & \multicolumn{5}{|c|}{4199.0235869 .2547218 .6999107 .57311704 .840} \\
\hline Mining and washing of coal & 115.204 & 197.578 & 288.825 & 358.727 & 469.633 \\
\hline Extraction of petroleum and natural gas & 238.822 & 333.130 & 481.396 & 598.666 & 645.083 \\
\hline Mining and processing of ferrous metal ores & 14.619 & 30.731 & 42.650 & 58.810 & 92.878 \\
\hline Mining and processing of non-ferrous metal ores & 17.765 & 27.201 & 42.760 & 67.757 & 97.332 \\
\hline Mining and processing of nonmetal ores & 16.288 & 20.684 & 28.051 & 37.812 & 51.724 \\
\hline Mining of other ores & 0.236 & 0.183 & 0.270 & 0.181 & 0.327 \\
\hline Processing of food from agricultural products & 146.642 & 207.040 & 274.596 & 349.209 & 464.245 \\
\hline Manufacture of foods & 66.709 & 86.957 & 116.832 & 146.725 & 186.156 \\
\hline Manufacture of beverages & 79.597 & 89.444 & 116.473 & 143.908 & 188.366 \\
\hline Manufacture of tobacco & 157.348 & 185.435 & 205.999 & 237.974 & 291.882 \\
\hline Manufacture of textiles & 190.670 & 260.111 & 324.019 & 396.299 & 491.392 \\
\hline M. of textile wearing apparel, footwear, and caps & 91.654 & 110.369 & 141.986 & 183.371 & 226.511 \\
\hline M. of leather & 59.135 & 73.650 & 94.438 & 117.286 & 148.039 \\
\hline Proc. of ti & 26.572 & 37.898 & 51.086 & 68.557 & 103.029 \\
\hline Manufacture of furniture & 18.296 & 30.216 & 38.487 & 50.109 & 64.676 \\
\hline Manufacture of paper and & 68.142 & 91.917 & 114.640 & 138.644 & 174.305 \\
\hline Printing, re & 33.446 & 38.760 & 46.306 & 55.776 & 69.194 \\
\hline M. of artic & 24.993 & 31.328 & 37.971 & 46.494 & 55.457 \\
\hline Proc & 128.745 & 163.805 & 198.164 & 231.423 & 309.698 \\
\hline terials and chemical prod. & 246.488 & 346.533 & 439.192 & 539.879 & 734.042 \\
\hline Manufacture of medicines & 102.474 & 115.787 & 152.980 & 180.809 & 228.660 \\
\hline Manufacture of chemical fibers & 29.525 & 37.995 & 48.531 & 60.417 & 80.943 \\
\hline Manufacture of rubber & 36.995 & 50.242 & 59.536 & 71.496 & 95.900 \\
\hline Manufac & 76.320 & 104.780 & 127.205 & 166.888 & 213.714 \\
\hline Man & 174.908 & 229.292 & 280.792 & 365.620 & 484.919 \\
\hline Smelting & 282.401 & 466.887 & 577.690 & 700.445 & 900.714 \\
\hline Smelting and processing of non-ferrous me & 90.213 & 148.475 & 192.965 & 319.800 & 447.761 \\
\hline Manufacture of metal products & 97.100 & 131.503 & 169.338 & 222.594 & 301.041 \\
\hline Manufact & 159.039 & 237.857 & 296.696 & 379.926 & 510.754 \\
\hline Manufactu & 100.819 & 136.570 & 168.156 & 229.635 & 306.736 \\
\hline Manufacture of transport equipment & 289.697 & 346.034 & 383.052 & 493.341 & 697.448 \\
\hline M. of electrical machinery and equip & 202.348 & 287.976 & 357.413 & 461.796 & 605.378 \\
\hline M. of communication equipm., computers, etc. & 348.250 & 480.476 & 572.211 & 708.430 & 792.457 \\
\hline M. of measuring instruments and mi & 44.503 & 58.712 & 73.319 & 96.794 & 116.325 \\
\hline Manufacture of artwork and other manufacturing & 34.774 & 44.912 & 57.083 & 70.572 & 91.762 \\
\hline Recycling and disposal of waste & 1.067 & 4.239 & 5.993 & 9.472 & 16.205 \\
\hline Prod. and distr. of electric power and heat power & 360.613 & 587.378 & 571.979 & 691.246 & 882.889 \\
\hline Production and distribution of gas & 7.534 & 11.250 & 13.452 & 19.171 & 30.667 \\
\hline Production and distribution of water & 19.074 & 22.947 & 26.164 & 31.514 & 36.596 \\
\hline Implicit residual & -0.002 & 2.974 & 0.003 & 0.000 & 0.002 \\
\hline
\end{tabular}

a: 2004 value-added is obtained by multiplying 2004 GOV by the average 2003 and 2005 ratio of GOV to value-added, sector by sector. The 2004 implicit residual is large in comparison to other years, but it is still only 0.05 percent of national value-added, which suggests the approximation method chosen could be quite reliable.

Abbreviations: for unabbreviated sector labels see GB2002 (reproduced in Carsten Holz, 2013). Source: Industrial Yearbook 2004, pp. 64f.; Economic Census 2004, pp. 10-38; Statistical Yearbook 2006, p. 511; 2007, p. 503; 2008, p. 487. 
Appendix 11. Directly Reporting Industrial Enterprise Gross Output Value 2003-2011 (b yuan)

\begin{tabular}{|c|c|c|c|c|c|c|c|c|c|c|}
\hline & 2003 & 2003 & 2004 & 2005 & 2006 & 2007 & 2008 & 2009 & 2010 & $2011^{\mathrm{a}}$ \\
\hline Total & 12871.6 & 14227.1 & 20172.2 & 25162.0 & 31658.9 & 40517.7 & 50744.8 & 54831.1 & 69859.1 & 84426.9 \\
\hline Mining and washing of coal & 117.16 & 245.94 & 406.64 & 572.28 & 720.76 & 920.18 & 1462.59 & 1640.43 & 2210.93 & \\
\hline Extraction of petroleum and natural gas & 88.65 & 347.90 & 460.15 & 628.63 & 771.88 & 830.01 & 1061.60 & 751.75 & 991.78 & 1288.88 \\
\hline Mining and processing & 23.29 & 35.09 & 72.54 & 98.96 & 138.83 & 213.06 & 376.07 & 380.25 & 599.93 & 790.43 \\
\hline Mining / processing of non-ferrous metal ores & 44.13 & 57.33 & 80.16 & 114.04 & 167.17 & 228.88 & 272.78 & 281.47 & 379.94 & 503.47 \\
\hline Mining and processing of nonmetal ores & 42.79 & 48.68 & 58.80 & 75.65 & 102.94 & 136.56 & 186.95 & 230.24 & 309.35 & 384.77 \\
\hline Mining of other ores & 0.69 & 0.75 & 0.58 & 0.86 & 0.52 & 1.10 & 1.04 & 1.39 & 3.13 & 1.67 \\
\hline Processing & 492.29 & 615.23 & 834.49 & 1061.50 & 1297.35 & 1749.61 & 2391.74 & 2796.10 & 3492.81 & 4412.61 \\
\hline Manufac & 204.45 & 229.01 & 289.91 & 377.94 & 471.43 & 607.10 & 771.65 & 921.92 & 1135.06 & 1404.70 \\
\hline Man & 183.16 & 223.32 & 244.09 & 308.93 & 389.92 & 508.23 & 625.05 & 746.50 & 915.26 & 1183.48 \\
\hline Mant & 107.11 & 223.58 & 259.60 & 284.07 & 321.41 & 377.62 & 448.89 & 492.50 & 584.25 & 680.57 \\
\hline Man & 698.93 & 772.52 & 1035.55 & 1267.17 & 1531.55 & 1873.33 & 2139.31 & 2297.14 & 2850.79 & 3265.30 \\
\hline M. o & 311.44 & 342.60 & 399.63 & 497.46 & 615.94 & 760.04 & 943.58 & 1044 & 1233.12 & 1353.81 \\
\hline ucts & 202.84 & 227.41 & 27 & 346.28 & 415.00 & 515.35 & 587.14 & 642.56 & 789.75 & 892.75 \\
\hline & 93.81 & 99.28 & 138.59 & 182.77 & 242.90 & 352.05 & 480.36 & 575.96 & 739.32 & 900.23 \\
\hline Manı & 64.35 & 72.00 & 115.48 & 142.73 & 188.31 & 242.49 & 307.28 & 343.11 & 441.48 & 508.98 \\
\hline Manufac & 222.32 & 252.61 & 337.19 & 416.13 & 503.49 & 632.55 & 787.39 & 826.44 & 1043.41 & 1207.95 \\
\hline Prin & 99.77 & 102.72 & 119.91 & 144.30 & 170.66 & 1.76 & 50 & 297.29 & 356.29 & 386.10 \\
\hline sports & 89.37 & 6.59 & 121.69 & 25 & 175.90 & 209.88 & 249.84 & 26 & 313.54 & 321.24 \\
\hline & 243.81 & 23.53 & 892.65 & 1200.05 & 1514.90 & 1785.09 & 2262.87 & 2149.26 & 2923.88 & 3688.92 \\
\hline M. of raw & 873.26 & 924.49 & 1295.27 & 1635.97 & 2044.87 & 2679.88 & 3395.51 & 3690.86 & 4792.00 & 6082.51 \\
\hline Manufactu & 389.56 & 289.00 & 324.13 & 425.05 & 501.89 & 636.19 & 787.50 & 944.33 & 1174.13 & 1494.20 \\
\hline Man & 174.39 & 144.84 & 195.30 & 260.84 & 320.56 & 412.08 & 397.02 & 382.83 & 495.40 & 667.37 \\
\hline Manı & 34.20 & 131.29 & 181.84 & 219.67 & 273.19 & 346.24 & 422.86 & 476.79 & 590.67 & 733.07 \\
\hline & 301.76 & 306.38 & 419.04 & 506.79 & 638.10 & 812.04 & 989.72 & 1096.94 & 1387.22 & 1557.95 \\
\hline Man & 503.19 & 565.33 & 745.99 & 919.52 & 1172.15 & 1555.94 & 2094.35 & 2484.39 & 3205.73 & 4018.03 \\
\hline Smel & 651.49 & 1000.74 & 1694.89 & 2147.10 & 2540.38 & 3370.30 & 4472.80 & 4263.62 & 5183.36 & 6406.70 \\
\hline Smelting and processing of non-ferrous metals & 309.54 & 356.41 & 598.68 & 793.80 & 1293.65 & 1803.19 & 2094.87 & 2056.72 & 2811.90 & 3590.68 \\
\hline Manufacture of metal products & 360.62 & 385.74 & 515.79 & 655.68 & 852.95 & 1144.71 & 1502.96 & 1608.30 & 2013.46 & 2335.08 \\
\hline Manufacture of general purpose machinery & 563.69 & 571.12 & 852.39 & 1061.04 & 1373.48 & 1841.55 & 2468.76 & 2736.15 & 3513.27 & 4099.26 \\
\hline
\end{tabular}




\begin{tabular}{|c|c|c|c|c|c|c|c|c|c|c|}
\hline Manufacture of special purpose machinery & 364.53 & 383.17 & 506.64 & 608.54 & 795.33 & 1059.20 & 1452.13 & 1678.44 & 2156.18 & 2614.91 \\
\hline Manufacture of transport equipment & 1193.51 & 1121.41 & 1379.55 & 1571.49 & 2038.29 & 2714.74 & 3339.53 & 4173.03 & 5545.26 & 6325.13 \\
\hline M. of electrical machinery and equipment & 902.62 & 791.62 & 1123.33 & 1390.13 & 1816.55 & 2401.91 & 3042.88 & 3375.80 & 4334.44 & 5142.64 \\
\hline M. of communication equipm., computers, etc. & 2238.59 & 1583.98 & 2226.03 & 2699.44 & 3307.76 & 3922.38 & 4390.28 & 4456.26 & 5497.07 & 6379.57 \\
\hline M. of measuring instruments and machinery etc. & 165.46 & 163.67 & 219.32 & 278.11 & 353.93 & 430.80 & 498.45 & 508.33 & 639.91 & 763.30 \\
\hline Manufacture of artwork and other manuf. & 122.09 & 130.66 & 164.46 & 203.57 & 253.32 & 338.77 & 408.86 & 446.52 & 566.27 & 718.95 \\
\hline Recycling and disposal of waste & 4.16 & 4.99 & 20.28 & 29.30 & 42.01 & 68.07 & 113.78 & 144.39 & 230.61 & 262.42 \\
\hline Prod. and distr. of electric power and heat power & 258.85 & 685.86 & 1471.81 & 1778.59 & 2154.93 & 2646.27 & 3006.05 & 3343.51 & 4055.08 & 4735.27 \\
\hline Production and distribution of gas & 15.89 & 27.26 & 41.88 & 51.47 & 73.21 & 98.87 & 150.66 & 180.91 & 239.34 & 314.20 \\
\hline Production and distribution of water & 13.86 & 43.11 & 51.32 & 57.90 & 71.48 & 79.71 & 91.26 & 101.23 & 113.71 & 117.81 \\
\hline Implicit residual & -0.004 & -0.001 & -0.001 & -0.001 & 0.000 & 0.000 & 0.000 & 0.001 & -0.001 & 0.002 \\
\hline
\end{tabular}

a: Starting in 2011, the minimum sales revenue requirement for an enterprise to be included in the DRIEs is $20 \mathrm{~m}$ (previously $5 \mathrm{~m}$ ). The coverage of DRIES likely expanded in 2004 due to the capture of previously omitted enterprises, and a slight redefinition of the group of DRIEs occurred in 2007.

Abbreviations: for unabbreviated sector labels see GB2002 (reproduced in Carsten Holz, 2013).

Sources: Industrial Yearbook 2004, pp. 64f.; Economic Census 2004, pp. 10-38; Statistical Yearbook 2006, p. 511; 2007, p. 502; 2008, p. 486; 2009, p. 488; 2010, p. 512; 2011, p. 500; 2012, p. 503. 
Appendix 12. Ex-Factory Price Index (Producer Price Index) by Industrial Sector (in \%), 2002-2011

\begin{tabular}{|c|c|c|c|c|c|c|c|c|c|c|}
\hline & 2002 & 2003 & 2004 & 2005 & 2006 & 2007 & 2008 & 2009 & 2010 & 2011 \\
\hline Total & -2.2 & 2.3 & 6.1 & 4.9 & 3.0 & 3.1 & 6.9 & -5.4 & 5.5 & 6.0 \\
\hline Mining and washing of coal & 13.0 & 3.8 & 16.8 & 23.2 & 5.0 & 3.8 & 28.7 & 1.9 & 10.0 & 10.2 \\
\hline Extraction of petroleum and natural gas & -5.4 & 19.1 & 19.6 & 29.9 & 22.0 & 2.0 & 22.1 & -34.0 & 37.8 & 24.5 \\
\hline Mining and processing of ferrous metal ores & 1.0 & 10.4 & 45.3 & 12.3 & -3.2 & 10.3 & 31.4 & -25.7 & 17.5 & 12.7 \\
\hline Mining and processing of non-ferrous metal ores & 0.8 & 7.2 & 17.6 & 19.6 & 23.4 & 12.6 & 4.8 & -11.1 & 19.0 & 15.0 \\
\hline Mining and processing of nonmetal ores & 0.2 & 0.2 & 5.8 & 9.3 & 2.5 & 3.1 & 11.0 & -2.2 & 6.4 & 9.1 \\
\hline Processing of food from agricultural products & -1.5 & 3.1 & 14.0 & 1.1 & 0.1 & 13.3 & 14.4 & -4.0 & 5.5 & 10.6 \\
\hline Manufacture of foods & -1.0 & -0.3 & 2.9 & 1.5 & 1.1 & 2.6 & 8.0 & 1.1 & 3.3 & 6.3 \\
\hline Manufact & -0.8 & -0.8 & 0.6 & 0.6 & 0.5 & 1.2 & 3.7 & 0.6 & 2.9 & 4.4 \\
\hline Manı & 3.5 & 0.6 & 1.1 & 0.9 & 0.5 & 0.4 & 0.5 & 0.5 & 0.4 & 0.3 \\
\hline Manu & -4.8 & 1.8 & 4.3 & 0.5 & 2.1 & 0.8 & 1.5 & -1.7 & 8.5 & 11.1 \\
\hline M. of te & -0.9 & -0.2 & 0.7 & -0.2 & 0.9 & 0.7 & 2.1 & -0.1 & 1.7 & 3.7 \\
\hline M. of & -0.9 & -0.3 & 0.9 & 2.5 & 1.2 & 2.4 & 2.3 & -1.5 & 1.7 & 4.5 \\
\hline Proc & -3.2 & -0.9 & 2.2 & 1.8 & 2.3 & 3.6 & 4.1 & -1.2 & 1.5 & 4.1 \\
\hline Manı & -1.0 & -0.4 & 1.8 & 2.7 & 0.3 & 1.5 & 3.3 & 0.2 & 1.4 & 2.4 \\
\hline Manı & -2.4 & -1.3 & 1.3 & 1.4 & 0.7 & 1.0 & 5.8 & -5.6 & 3.5 & 3.0 \\
\hline Printi & -3.0 & -2.4 & -1.9 & -0.4 & -0.2 & 0.5 & 2.6 & -0.1 & 0.7 & 1.9 \\
\hline M. of & -2.2 & 0.2 & 2.2 & 2.0 & 1.4 & 1.5 & 1.9 & 0.3 & 2.4 & 3.7 \\
\hline Proc. o & -3.6 & 14.7 & 12.2 & 18.4 & 18.0 & 5.0 & 20.3 & -8.8 & 17.8 & 14.9 \\
\hline M. of raw chemical materials and chemical prod. & -1.1 & 3.4 & 10.2 & 8.5 & 0.4 & 3.8 & 11.2 & -11.9 & 8.0 & 9.8 \\
\hline Manufacture of medicines & -1.7 & -1.2 & -2.2 & 1.6 & -1.4 & 2.1 & 3.8 & 0.2 & 3.2 & 2.5 \\
\hline Manufacture of cher & -6.6 & 4.5 & 8.1 & 4.7 & 1.2 & 3.3 & -0.6 & -9.5 & 14.1 & 12.1 \\
\hline Manu & -2.3 & 0.0 & 1.0 & 4.5 & 4.7 & 3.3 & 4.9 & -0.4 & 3.8 & 10.0 \\
\hline of plastics & -3.8 & -0.2 & 6.5 & 5.5 & 1.0 & 2.0 & 2.7 & -3.9 & 2.3 & 4.7 \\
\hline Manufactu & -2.3 & -0.4 & 3.3 & 0.6 & 1.5 & 1.3 & 7.9 & -0.1 & 2.1 & 7.0 \\
\hline Smelti & -1.5 & 10.1 & 18.9 & 4.7 & -4.0 & 7.9 & 19.7 & -16.1 & 7.4 & 9.8 \\
\hline Smel & -4.6 & 5.1 & 18.9 & 11.7 & 22.5 & 13.9 & -3.2 & -16.6 & 17.3 & 13.0 \\
\hline Manu & -2.4 & 0.4 & 7.4 & 4.0 & 1.0 & 2.6 & 6.7 & -3.2 & 1.7 & 4.1 \\
\hline Manu & -1.8 & -0.2 & 3.1 & 1.8 & 0.2 & 1.3 & 4.8 & -1.3 & 0.1 & 2.7 \\
\hline Manu & -1.2 & -0.4 & 1.8 & 1.8 & 1.2 & 1.5 & 3.3 & 0.0 & 1.2 & 1.5 \\
\hline Manufacture of transport equipment & -3.3 & -2.1 & -1.8 & -1.2 & -0.5 & 0.1 & 1.5 & -0.1 & 0.3 & 0.4 \\
\hline
\end{tabular}




\begin{tabular}{|c|c|c|c|c|c|c|c|c|c|c|}
\hline M. of electrical machinery and equipment & n.a. & -2.1 & 3.7 & 3.2 & 7.4 & 3.7 & 1.1 & -5.0 & 3.2 & 3.1 \\
\hline M. of communication equipm., computers, etc. & -3.5 & -6.3 & -4.9 & -4.8 & -3.4 & -2.5 & -1.7 & -4.3 & -1.7 & -1.7 \\
\hline M. of measuring instruments and machinery etc & -6.9 & -2.7 & -1.5 & -1.3 & -0.8 & -1.1 & 0.3 & -0.9 & -0.9 & -0.2 \\
\hline Manufacture of artwork and other manufacturing & -4.8 & 2.1 & 5.7 & 3.9 & 2.5 & 4.3 & 5.5 & 0.5 & 3.5 & 5.3 \\
\hline Recycling and disposal of waste & 0.7 & 11.5 & 16.9 & 5.3 & 3.4 & 4.4 & 8.9 & -15.0 & 7.5 & 11.8 \\
\hline er and heat power & 0.7 & 0.9 & 2.4 & 4.2 & 2.8 & 2.2 & 1.8 & 2.3 & 2.0 & 1.6 \\
\hline Produ & 1.3 & 3.3 & 2.5 & 5.2 & 6.8 & 4.8 & 5.9 & 0.5 & 5.4 & 9.4 \\
\hline Production and distribution of water & 6.2 & 5.3 & 4.1 & 4.0 & 6.4 & 4.8 & 2.9 & 3.2 & 5.5 & 2.8 \\
\hline
\end{tabular}

Abbreviations: for unabbreviated sector labels see GB2002 (reproduced in Carsten Holz, 2013).

Source: Statistical Yearbook 2006, p. 335 (for 2002-2005); 2008, p. 303 (for 2006-2007); 2012, p. 332 (for 2008-2011). While the Chinese title of the tables in the sources is unchanged, the English title between 2006 and 2008 changed from "ex-factory price index of industrial products" to "producer price index for manufactured goods." 
Appendix 13. Aggregate Expenditures and Real Growth Rates

\begin{tabular}{|c|c|c|c|c|c|c|c|c|c|c|c|c|c|c|c|c|c|c|}
\hline & \multicolumn{10}{|c|}{ Aggregate expenditures (b yuan) } & \multicolumn{8}{|c|}{ Real growth rates in \% } \\
\hline & \multirow[t]{3}{*}{ Total } & \multicolumn{5}{|c|}{ Consumption } & \multicolumn{3}{|c|}{ Gross capital formation } & \multirow{3}{*}{$\begin{array}{l}\text { Net } \\
\text { exp. }\end{array}$} & \multicolumn{5}{|c|}{ Consumption } & \multicolumn{3}{|c|}{ GCF } \\
\hline & & All & \# & \#\# & \#\# & \# & All & \# & \# & & All & \# & \#\# & \#\# & \# & All & \# & \# \\
\hline & & & Househ. & Rural & Urban & Gov. & & GFCF & Invent. & & & Hh. & Rur. & Urb. & Gov. & & Fix. & Inv. \\
\hline 1952 & 69.21 & 54.63 & 45.30 & 31.22 & 14.08 & 9.33 & 15.37 & 8.07 & 7.30 & -0.79 & & & & & & & & \\
\hline 1953 & 83.43 & 64.44 & 52.92 & 34.67 & 18.25 & 11.52 & 19.83 & 11.53 & 8.30 & -0.84 & 12.5 & 9.8 & 4.2 & 22.5 & 25.7 & 29.9 & 44.6 & 13.7 \\
\hline 1954 & 87.83 & 65.41 & 55.00 & 36.32 & 18.68 & 10.41 & 22.69 & 14.09 & 8.60 & -0.27 & 1.3 & 3.1 & 4.0 & 1.3 & -6.1 & 13.9 & 23.0 & 1.2 \\
\hline 1955 & 93.49 & 72.23 & 60.26 & 40.62 & 19.64 & 11.97 & 22.15 & 14.55 & 7.60 & -0.89 & 10.7 & 9.2 & 11.3 & 5.0 & 17.5 & 1.5 & 7.9 & -9.5 \\
\hline 1956 & 103.42 & 77.26 & 64.68 & 41.42 & 23.26 & 12.58 & 25.76 & 21.96 & 3.80 & 0.40 & 6.5 & 7.2 & 1.7 & 18.6 & 3.3 & 20.6 & 51.4 & -42.1 \\
\hline 1957 & 110.19 & 81.64 & 68.66 & 43.05 & 25.61 & 12.98 & 28.00 & 18.70 & 9.30 & 0.55 & 5.1 & 5.3 & 4.0 & 7.7 & 4.3 & 9.4 & -11.1 & 118.2 \\
\hline 1958 & 129.11 & 85.26 & 72.40 & 45.42 & 26.98 & 12.86 & 43.20 & 33.30 & 9.90 & 0.65 & 3.4 & 4.2 & 3.2 & 5.7 & -0.7 & 54.2 & 77.4 & 7.5 \\
\hline 1959 & 145.14 & 82.15 & 69.12 & 36.26 & 32.86 & 13.03 & 62.17 & 43.57 & 18.60 & 0.82 & -5.3 & -6.6 & -20.2 & 15.8 & 2.0 & 35.6 & 20.7 & 85.0 \\
\hline 1960 & 150.80 & 93.26 & 74.17 & 37.02 & 37.15 & 19.09 & 57.50 & 47.30 & 10.20 & 0.04 & 2.9 & -5.2 & -6.4 & -3.9 & 43.9 & -7.7 & 8.9 & -43.8 \\
\hline 1961 & 127.51 & 99.51 & 81.67 & 44.52 & 37.15 & 17.84 & 27.46 & 22.76 & 4.70 & 0.54 & -8.7 & -7.3 & 1.5 & 17.0 & -13.4 & -51.9 & -51.0 & -55.8 \\
\hline 1962 & 117.64 & 98.57 & 83.87 & 48.64 & 35.23 & 14.70 & 17.81 & 17.51 & 0.30 & 1.26 & -0.3 & 4.5 & 9.6 & -2.4 & -17.5 & -41.0 & -28.3 & n.a. \\
\hline 1963 & 129.31 & 101.43 & 84.42 & 51.33 & 33.09 & 17.01 & 26.53 & 21.53 & 5.00 & 1.35 & 12.1 & 12.2 & 11.8 & 12.7 & 12.1 & 43.4 & 17.3 & n.a. \\
\hline 1964 & 144.18 & 107.86 & 88.96 & 56.29 & 32.67 & 18.90 & 35.03 & 29.03 & 6.00 & 1.29 & 9.2 & 8.1 & 10.6 & 4.2 & 14.3 & 35.4 & 37.7 & 25.0 \\
\hline 1965 & 162.92 & 115.86 & 95.15 & 60.83 & 34.32 & 20.71 & 46.21 & 35.01 & 11.20 & 0.85 & 12.2 & 12.4 & 12.7 & 12.1 & 11.1 & 40.1 & 24.7 & 116.0 \\
\hline 1966 & 182.72 & 25.13 & 102.11 & 66.45 & 35.66 & 23.02 & 56.98 & .68 & 6.30 & 0.61 & 7.2 & 6.1 & 7.0 & 4.5 & 11.9 & 25.2 & 18.5 & 44.4 \\
\hline 1967 & 170.77 & 27.57 & 108.15 & 71.05 & 37.10 & 19.42 & 42.57 & 32.37 & 10.20 & 0.63 & 1.8 & 6.0 & 7.2 & 3.9 & -15.5 & -23.9 & -20.7 & -31.4 \\
\hline 1968 & 170.87 & 126.91 & 107.66 & 70.40 & 37.26 & 19.25 & 43.22 & 30.02 & 13.20 & 0.74 & -0.8 & -0.7 & -1.3 & 0.5 & -1.4 & 6.2 & -4.0 & 33.7 \\
\hline 1969 & 185.77 & 135.94 & 112.77 & 74.11 & 38.66 & 23.17 & 48.59 & 40.69 & 7.90 & 1.24 & 8.2 & 5.5 & 6.2 & 4.4 & 22.0 & 13.7 & 38.7 & -35.0 \\
\hline 1970 & 220.69 & 145.97 & 120.68 & 80.22 & 40.46 & 25.29 & 74.49 & 54.59 & 19.90 & 0.23 & 7.3 & 6.9 & 8.1 & 4.9 & 9.2 & 53.4 & 34.2 & 133.3 \\
\hline 1971 & 239.25 & 55.79 & 126.20 & 84.27 & 41.93 & 29.59 & 81.90 & 60.30 & 21.60 & 1.56 & 6.4 & 4.1 & 4.3 & 3.8 & 17.3 & 9.2 & 9.3 & 9.1 \\
\hline 1972 & 245.38 & 54.43 & 133.42 & 86.52 & 46.90 & 31.01 & 79.11 & 62.21 & 16.90 & 1.84 & 5.3 & 5.4 & 2.3 & 11.5 & 5.0 & -4.3 & 1.9 & -21.2 \\
\hline 1973 & 266.96 & 175.13 & 143.25 & 93.66 & 49.59 & 31.88 & 90.35 & 66.45 & 23.90 & 1.48 & 6.2 & 7.1 & 7.9 & 5.6 & 2.4 & 14.4 & 6.7 & 41.5 \\
\hline 1974 & 273.88 & 180.96 & 146.70 & 95.43 & 51.27 & 34.26 & 93.61 & 74.81 & 18.80 & -0.69 & 3.0 & 2.0 & 1.5 & 2.9 & 7.4 & 3.2 & 12.4 & -21.5 \\
\hline 1975 & 295.04 & 188.74 & 152.85 & 98.70 & 54.15 & 35.89 & 106.23 & 88.03 & 18.20 & 0.07 & 4.1 & 4.0 & 3.4 & 5.2 & 4.4 & 12.1 & 16.3 & -3.7 \\
\hline 1976 & 296.84 & 196.95 & 158.85 & 101.14 & 57.71 & 38.10 & 99.01 & 86.51 & 12.50 & 0.88 & 4.3 & 3.7 & 2.3 & 6.3 & 6.5 & -6.9 & -2.4 & -27.9 \\
\hline 1977 & 316.60 & 05.78 & 164.78 & 102.13 & 62.65 & 41.00 & 109.81 & 91.11 & 18.70 & 1.01 & 3.6 & 2.7 & 1.1 & 5.6 & 7.2 & 9.5 & 3.8 & 45.5 \\
\hline 1978 & 360.56 & 223.91 & 175.91 & 109.24 & 66.67 & 48.00 & 137.79 & 107.39 & 30.40 & -1.14 & 7.8 & 5.5 & 5.5 & 5.7 & 16.9 & 25.1 & 17.2 & 60.4 \\
\hline 1979 & 409.26 & 263.37 & 201.15 & 125.29 & 75.86 & 62.22 & 147.89 & 115.31 & 32.58 & -2.00 & 12.7 & 8.3 & 6.3 & 11.6 & 28.5 & 3.7 & 5.1 & -0.9 \\
\hline 1980 & 459.29 & 300.79 & 233.12 & 141.10 & 92.02 & 67.67 & 159.97 & 132.24 & 27.73 & -1.47 & 8.8 & 10.4 & 8.8 & 12.9 & 4.0 & 5.8 & 11.3 & -13.2 \\
\hline 1981 & 500.88 & 336.15 & 262.79 & 160.38 & 102.41 & 73.36 & 163.02 & 133.93 & 29.09 & 1.71 & 9.3 & 9.7 & 10.4 & 8.6 & 7.8 & -0.8 & -1.9 & 4.2 \\
\hline
\end{tabular}




\begin{tabular}{|c|c|c|c|c|c|c|c|c|c|c|c|c|c|c|c|c|c|c|}
\hline 82 & & & & & & & & & & & 9.0 & $\cdots$ & .5 & 5.7 & 11 & . & .7 & \\
\hline 1983 & & & & & & & & & & & 9.8 & 9.7 & 11.2 & 7.3 & & 1.3 & 11.9 & \\
\hline & & & & & & & & & & & & .5 & 13.0 & & & .9 & .7 & \\
\hline & & & & & & & & & & & & & 13.3 & 17.9 & & 28.4 & 6.1 & 87 \\
\hline 86 & & & & & & & & & & & 8.0 & 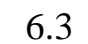 & & & & 7.5 & 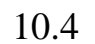 & \\
\hline 987 & & & & & & & & & & & 7.6 & & & & & 6.5 & & \\
\hline 88 & & & & & & & & & & & 8.5 & & 6.0 & & & & & \\
\hline & & & & & & & & & & & 2.2 & & .8 & & & & & \\
\hline & & & & & & & & & & & 6.6 & & & & & & & \\
\hline & & & & & & & & & & & & & & & & . & J.3 & $0.7^{2}$ \\
\hline & & & & & & & & & & & & & & & & & 4.1 & 23. \\
\hline & & & & & & & & & & & 9.9 & & & 3.8 & & .7 & 5.0 & 23.0 \\
\hline & & & & & & & & & & & 6.9 & & & 7.6 & & .0 & 7.9 & 10.8 \\
\hline & & & & & & & & & & & 8.6 & 9. & .1 & 10.4 & 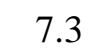 & 16.1 & 3.8 & 29. \\
\hline 6 & & & & & & & & & & 92 & 10.7 & 10.6 & 14.1 & 8.1 & 11 & 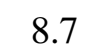 & 10.8 & -1. \\
\hline & & & & & & & & & & & 6.1 & 5.6 & 1 & .2 & 0 & 4 & 6.2 & -5. \\
\hline & & & & & & & & & & & 7.6 & $a_{0}$ & .1 & 1.8 & 8 & 5.2 & 10.0 & 25.7 \\
\hline 99 & & & & & & & & & & & 9.2 & 9.2 & .8 & 2.7 & 9.0 & 4.4 & 73 & 22.4 \\
\hline 00 & & & & & & & & & & & 10.0 & 9.4 & 3.0 & 13.2 & 1.8 & 5.4 & 9 & 50.7 \\
\hline 011 & & & & & & & & & & & 7.8 & 6.4 & 2. & .2 & 11.7 & 13.8 & 1.1 & 103.8 \\
\hline 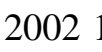 & & & & & & & & & & & 7.6 & 7.2 & & .0 & 8.8 & 14.3 & 5.3 & -5.5 \\
\hline , & & & & & & & & & & & 7.1 & 7.2 & -1.4 & 0 & 6.8 & 20.1 & 9.9 & 26.5 \\
\hline & & & & & & & & & 5.07 & .56 & 8.2 & 8.1 & 1.7 & 10.6 & 8.5 & 16.5 & 14.6 & 55. \\
\hline & & & & & & & & & 62 & 91 & n.a. & n.a. & n.a. & n.a. & n.a. & n.a. & n.a. & 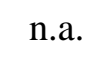 \\
\hline 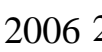 & & & דזרט & & 6 & & 41 & 41 & 00 & .46 & n.a. & n.a. & n.a. & n.a. & n.a. & n.a. & n.a. & $1 . \mathrm{a}$ \\
\hline 07 & & & 9633.25 & 2420.56 & 7212.69 & 590.04 & 1094.32 & 10394.86 & 699.46 & 42.31 & n.a. & n.a. & n.a. & n.a. & n.a. & n.a. & n.a. & n.a. \\
\hline & & & & & 839 & & & 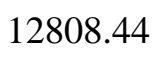 & & & n.a & 11. $\mathrm{a}$ & n.a. & n.a. & d. & n.a. & 11.d & 1.a \\
\hline & & & & & & & & & & & n.a. & $11 . \mathrm{d}$ & n.a. & n.a. & n.d. & n.a. & n.d & 1.6 \\
\hline & & & & & & & & & 998. & & n.a. & n.a. & n.a. & n.a. & n.a. & n.a. & n.a. & n.a \\
\hline 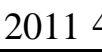 & 57 & 1 & 4945 & 73946 & 7550 & 3616 & 250006 & & & & n.a. & 11.d. & n.a. & n.a. & n.a. & n.a. & 1.a. & n.c \\
\hline
\end{tabular}
Sources: Nominal values: 1952-1978 or 2000: GDP 1952-2004, pp. 18, 20, 25; 1978 or 2000 onwards: Statistical Yearbook 2012, pp. 61f. Real growth rates: GDP 1952-2004, pp. 22, 26; since nominal values in the two sources differ in the years 2001-2004, the real growth rates of 2001-2004 may not match the (revised, presented here) nominal values (the revisions to the nominal values are small, below half a percentage point for the aggregate and less than four percentage points for any one category in any one year 2001-2004). 
Appendix 14. Economy-wide Income (b yuan)

\begin{tabular}{|c|c|c|c|c|c|}
\hline & Total & $\begin{array}{c}\text { Labor } \\
\text { remuneration }\end{array}$ & Depreciation & $\begin{array}{l}\text { Net taxes on } \\
\text { production }\end{array}$ & $\begin{array}{l}\text { Operating } \\
\text { surplus }\end{array}$ \\
\hline \multicolumn{6}{|c|}{ A. Pre-economic census 2004} \\
\hline 1978 & 344.046 & 170.841 & 33.394 & 44.081 & 95.730 \\
\hline 1979 & 391.799 & 201.306 & 37.679 & 47.872 & 104.942 \\
\hline 1980 & 436.787 & 223.406 & 42.883 & 52.976 & 117.522 \\
\hline 1981 & 475.960 & 250.751 & 47.464 & 56.663 & 121.082 \\
\hline 1982 & 529.158 & 283.451 & 53.004 & 61.498 & 131.204 \\
\hline 1983 & 593.977 & 318.040 & 60.131 & 68.818 & 146.987 \\
\hline 1984 & 707.459 & 379.765 & 70.828 & 83.435 & 173.432 \\
\hline 1985 & 857.739 & 453.751 & 85.331 & 103.380 & 215.277 \\
\hline 1986 & 961.045 & 507.630 & 100.795 & 120.212 & 232.389 \\
\hline 1987 & 1139.898 & 592.986 & 122.525 & 142.258 & 282.130 \\
\hline 1988 & 1438.852 & 744.209 & 153.527 & 187.936 & 353.173 \\
\hline 1989 & 1629.663 & 839.481 & 184.277 & 216.562 & 389.342 \\
\hline 1990 & 1835.723 & 980.627 & 214.284 & 239.695 & 401.117 \\
\hline 1991 & 2114.201 & 1102.782 & 260.608 & 280.525 & 470.296 \\
\hline 1992 & 2589.232 & 1297.055 & 333.173 & 346.290 & 612.714 \\
\hline 1993 & 3422.769 & 1732.740 & 398.912 & 472.912 & 818.194 \\
\hline 1994 & 4538.368 & 2323.582 & 540.688 & 618.475 & 1055.624 \\
\hline 1995 & 5763.278 & 3045.377 & 711.633 & 740.730 & 1265.538 \\
\hline 1996 & 6858.430 & 3662.220 & 878.142 & 862.186 & 1455.882 \\
\hline 1997 & 7695.661 & 4062.824 & 1048.641 & 1012.499 & 1571.697 \\
\hline 1998 & 8278.025 & 4398.895 & 98.124 & 109.235 & 1571.771 \\
\hline 1999 & 8767.113 & 4592.643 & 1320.904 & 1187.017 & 1666.549 \\
\hline 2000 & 9720.937 & 4994.806 & 1497.242 & 1376.027 & 1852.862 \\
\hline 2001 & 10676.630 & 5493.465 & 28 & .736 & 2002.497 \\
\hline 2002 & 11802.070 & 6009.914 & 377 & .312 & 2285.464 \\
\hline 2003 & 13553.910 & 6726.069 & 147 & 242 & 2736.456 \\
\hline \multicolumn{6}{|c|}{ B. Post-economic census 2004} \\
\hline 1993 & 3421.955 & 1693.455 & 480.772 & 620 & 848.109 \\
\hline 1994 & 4534.514 & 2282.904 & 88 & 198 & 1080.323 \\
\hline 1995 & 5753.520 & 2959.680 & 745.709 & 705.676 & 1342.454 \\
\hline 1996 & 6776.415 & 3470.364 & 863.417 & 873.667 & 1568.968 \\
\hline 1997 & 7633.924 & 3895.449 & 995.812 & 1042.029 & 1700.634 \\
\hline 1998 & 8255.851 & 4196.046 & 1093.251 & 1176.896 & 1789.658 \\
\hline 1999 & 8821.562 & 4408.216 & 1184.727 & 1313.630 & 1914.989 \\
\hline 2000 & 9850.414 & 4797.769 & 1385.488 & 1507.857 & 2159.300 \\
\hline 2001 & 10854.570 & 5235.129 & 1511.393 & 1696.757 & 2411.295 \\
\hline 2002 & 12057.100 & 5757.679 & 1664.355 & 1879.446 & 2755.623 \\
\hline 2003 & 13925.000 & 6427.153 & 1937.647 & 2196.209 & 3363.995 \\
\hline 2004 & 16758.710 & 6963.964 & 2362.401 & 2356.856 & 5075.491 \\
\hline 2005 & 19778.900 & 8188.802 & 2952.199 & 2791.921 & 5845.981 \\
\hline 2006 & 23105.330 & 9382.283 & 3272.666 & 3364.184 & 7086.202 \\
\hline 2007 & 27562.460 & 10953.227 & 4082.752 & 3901.885 & 8624.597 \\
\hline 2008 & n.a. & n.a. & n.a. & n.a. & n.a. \\
\hline 2009 & 530.369 & 29.971 & 4936.964 & 5553.111 & 9010.324 \\
\hline 2010 & 43704.199 & 19671.407 & 5622.758 & 6660.873 & 11745.661 \\
\hline 2011 & 52144.111 & 23431.025 & 6734.453 & 8139.925 & 13838.708 \\
\hline
\end{tabular}


All data are summed provincial values.

Sources: pre-economic census 1978-1995: GDP 1952-95, numerous pages; pre-economic census 19962003: individual issues of the Statistical Yearbook; post-economic census: GDP 1952-2004, pp. 63-68 (with the total obtained as summed income components), and Statistical Yearbook 2006, 2007, 2008, (2009,) 2010, 2011, 2012. 
1 For details on the sectoral classification systems see Carsten Holz (2013).

2 On the Chinese differences, see Xu Xianchun (2001). Some of these have been addressed in the benchmark revision following the 2004 economic census (Xu Xianchun, 2006).

3 Xu Xianchun (2009, pp. 450-9) provides an overview of the development of China's system of national accounts under the SNA since the 1990s.

4 A further volume, GDP 1952-96, reports substantially less data than GDP 1952-95, but includes one more year (1996).

5 An example of what has not become redundant is detailed household consumption expenditure data: GDP 1952-2004 offers a breakdown into rural vs. urban household consumption expenditures, but the pre-economic census GDP 1952-95 goes one step further in that it provides a further breakdown of rural and of urban household consumption expenditures by consumption categories for all years 1952-1995, and similarly do GDP 1952-96 and, at the provincial level, GDP 1996-2002, for the later years. GDP 1952-2004 revises the household consumption data published in GDP 1952-95 and the subsequent volumes; the revised aggregate household consumption expenditure data in GDP 1952-2004 can thus not be easily combined with the more detailed household consumption expenditure data published earlier. Starting with the 2007 issue, the Statistical Yearbook provides details on consumption categories, for the years starting with 2004.

6 In 1988, Hainan became a separate province; previously, it was part of Guangdong. In 1997, Chongqing became a separate province; previously, it was part of Sichuan. Different data sources start to report Hainan and Chongqing separately from Guangdong and Sichuan at different points of time.

7 See NBS (1997), pp. 12f., or NBS (2007); both sources offer detailed explanations for all economic sectors and subsectors.

8 In some tables, the additional coverage is for the years 1952, 1958, 1963, 1966, 1971, 1976, 1981, 1986, 1989, and 1990-1995, in others it is for the years 1952, 1978, 1985, 1990, and 1995.

9 The Statistical Yearbook 2005 for 2004 does not report value-added by industrial sector (but data on other variables). The Statistical Yearbook 2006 for 2005 again reports value-added (now with post-economic census 2004 values) by industrial sector. Value-added by industrial sector for 2004 is also not reported in the Industrial Yearbook series. GDP 1952-2004, pp. 15f., reports value-added by industrial sector, covering all industrial enterprises (i.e., not only the DRIEs).

10 One further national source of industrial sectoral data is the China Markets Yearbook, discontinued with the 2006 volume containing 2004 data, which covers approximately 500 individual three-digit industries since 1995 (but not continuously for every year since 1995). The enterprise coverage is the DRIEs. The list of industries is not exhaustive in some industrial sectors (and an aggregate is not provided in this source). Data are reported on nine variables; value-added and GOV are not included, only revenues. Value-added can be backed out of the two variables labor productivity and average number of employees. Data are reported industry-wide and by a nonexhaustive ownership breakdown into SOEs (covering either only the traditional SOEs, or the traditional SOEs, SOE-SOE joint enterprises, and 100 percent state-owned limited liability companies), collective-owned enterprises, and foreign and overseas Chinese funded enterprises.

11 The breakdown for consumption is into household and government consumption, for household consumption into farmer and non-farmer consumption, and for these latter two categories into four and three exhaustive subcategories. Gross capital formation comes with a breakdown into gross fixed capital formation and changes in inventories.

12 See the introductory sections of GDP 1952-95 and of GDP 1996-2002.

13 Table 2 also includes a national comparison, possible only between summed sectoral value-added and (total) expenditures because no income data are published at the national level. At the national level, expenditure approach GDP is presumably compiled independently; data on net exports, now with regard to foreign countries, are available at the national level. (The 2010 ratio of national value-added to expenditures is 101.7 percent.)

14 The same provinces show an approximately same discrepancy between the three approaches in 2010 as in 2007, except that in 2010 all three values are identical for Chongqing, while Tibet newly shows a minute discrepancy. 
15 See Carsten Holz (2002) for details on some of the problems specific to the different approaches to calculating GDP. Carsten Holz (2004a) examines the NBS explanations of how household consumption expenditures are compiled.

16 China Infobank, 29 February 2000.

17 See, for example, Pan Zhenwen and An Yuli (2003).

18 The (first published) implicit deflator of 2010, for example, is based on the nominal values of 2009 and 2010 and the 2010 real growth rate as published in the Statistical Yearbook 2011. The (first published) implicit deflator of 2011 relies on values from the Statistical Yearbook 2012, etc.

19 The starting year is 1987 because the Statistical Yearbook 1988 (with most recent data for 1987) is the first Statistical Yearbook issue with GDP data. For some data limitations in the years 1987-1991, see notes to the table.

${ }_{20} 16.8$ percent appears an almost impossibly high growth rate. Checking the underlying values, the growth rate of (published) nominal GDP is $22.9 \%$ and the derivation of the first published implicit deflator is correct; for comparison, the CPI is 4.8\% (Statistical Yearbook 2012, pp. 44, 311).

21 Compare Statistical Yearbook 1995, p. 377, and 2000, p. 409, or see the discussion in Carsten Holz and Yi-min Lin (2001a). GOV data of collective-owned enterprises, individual-owned and private enterprises, and enterprises in other (non-state) ownership for 1994 were retrospectively adjusted downward by 19 percent, 25 percent, and 16 percent, with similar or lesser revisions for the years 1991 through 1993. That data on SOEs were not retrospectively revised downward may be due to the fact that all SOEs are regularly reporting to the statistics xitong, whereas not all enterprises in non-state ownership are.

22 For the non-state enterprises, the NBS is unlikely to have any intermediate input data, nor value-added data, to begin with. Value-added in these enterprises is in all likelihood estimated as GOV times a value-added rate, which itself is estimated from a sample of non-DRIEs. I.e., theoretically, industrial value-added should have been revised along with GOV; in practice, given the data limitations, it may have seemed preferable not to attempt to adjust industrial value-added in the NIPA.

${ }^{23}$ The published real growth rate for GDP in 2006 changed, but this is presumably due to the annual revision of GDP data that happened in the publication reporting the changed real growth rate of GDP in 2006 (and the unchanged real growth rate of GDP in 2005), rather than to any effect from the agricultural sector nominal revisions. For the revisions, see the Statistical Yearbook 2008, pp. 37, 40; for the pre-revision data see the Statistical Yearbook 2007, pp. 57 and 59.

24 The announcement also includes a GDP index with its 1978 value set at 100. The original GDP index reported in the Economic Census 2004 (9 Jan. 2006) is identical to the original GNP index in the Statistical Yearbook 2005, p. 54, rather than the original GDP index (which must be a mistake). The published revised GDP index implies annual real growth rates that match the published revised (annual) real GDP growth rates.

25 Three years later, the same author (head of the national income accounts division of the NBS), in Xu Xianchun (2009, p. 457), provides a 6-item breakdown of how the production coverage of GDP was expanded in the year of the economic census to newly include: (i) some enterprise service activities (that are not covered in annual statistics), (ii) service activities of administrative and public institutional units (that are not covered in the annual statistics), (iii) production activities of those household unincorporated enterprises that did not register with the authorities, (iv) establishments whose activities differ from the principal activities of the enterprises to which they belong, and (v) housing rent services from households, and (vi) domestic and personal services produced by employing paid domestic staff that had not previously been estimated.

26 The 1993 SNA considers expenditures on computer software gross fixed capital formation; the 1968 version considered them an intermediate input.

27 Xinbao (Hong Kong Economic Journal [a newspaper]), 22 May 2006.

28 In 2003, the most recent year for which the pre-economic census values are available, value-added in agricultural services, classified with the tertiary sector, was equivalent to 1.85 percent of primary sector value-added (Statistical Yearbook 2005, pp. 51, 55).

29 And why do they cover only the period 1993-2004 and not 1978-1992? The years 1978-1993 were subject to the previous benchmark revision following the 1993 tertiary sector census; that census largely retained the earlier published implicit deflators. 
30 See p. 8 in Xu Xianchun (2006), where he reports that "the economic census led to the discovery that the previous data sources were missing a lot so that many economic activities were left out.”

31 For the data, see Statistical Yearbook 2005, pp. 488, 493, and Economic Census 2004, Vol. 2, pp. 10ff.

32 Several years after the 2006 benchmark revision, Xu Xianchun (2009, p. 460), head of the national income accounts division of the NBS, in a personal publication in an academic journal claims that following the economic census of 2004, tertiary sector values were revised back to 1953 with accompanying revisions to the value-added of the two subsectors 'finance and insurance' and real estate.

33 If this explanation of the revision of tertiary sector value-added for 1978-1992 were correct, then Guangdong either never implemented the 1993 tertiary sector census, or the original national GDP values (prior to the benchmark revision) experienced a statistical break in 1994 with unrevised Guangdong tertiary sector values for the years 1978-1993 and then revised values starting in 1994.

34 The upward revision contrasts sharply with Angus Maddison's (1998) downward revisions to China's reform period real growth rates, questioned by Carsten Holz (2006a). Harry Wu (2007) examines in greater detail the official retrospective adjustment method to nominal value-added (and GDP); he is particularly interested in the fact that the 1998 real GDP growth rate is the only one that has not been adjusted (Table 5). I.e., apart from the problems noted here, there may also exist an NBS intention to adjust values around a desired 1998 real growth rate.

35 In detail, (i) the nominal revised (post-economic census) value-added of the primary sector, secondary sector, and the tertiary sector of all years 1993-2004 is deflated using the first published implicit deflators of these sectors (as calculated from first published nominal and real growth data in the Statistical Yearbook series); (ii) the real growth rates of the primary sector, secondary sector, and tertiary sector are aggregated into real GDP growth rates using the Törnqvist index with post-economic census nominal value-added of these three sectors as weights. The calculations assume that the earlier implicit sectoral deflators are appropriate for the new classification. Beyond reclassifications at the level of the three main economic sectors, this also ignores the fact that the first published tertiary sector deflator may no longer be accurate due to changes to the relative nominal values of tertiary sector subsectors in the benchmark revision.

36 The data on cumulative real growth of consumption (with its various subcategories) for 1978-1989 published in GDP 1996-2002 (p. 25) are in all likelihood erroneous. The reasoning why these data in GDP 1996-2002 are likely to be erroneous is as follows. GDP 1996-2002 (p. 24) reports annual real growth rates for 1981, 1986, and the years since 1989; these values differ from the cumulative real growth figures that it reports for 1981, 1986 and 1989. (It publishes cumulative real growth figures for all reform years.). GDP 1952-95 reports both cumulative and annual real growth rates for all years of the reform period (the two series are consistent with each other) that match all (1981, 1986, and 1989-1995) annual real growth rates published in GDP 1996-2002, but not the 1979-1989 cumulative real growth figures in GDP 1996-2002; i.e., given the contradictory data, the majority of the available data (and consistently for GDP 1952-95) point towards using the real growth rates for 1978-1989 published in GDP 1952-95. If the cumulative real growth figures for 1978-1989 from GDP 1996-2002 were used, the comparisons conducted below would yield no patterns.

37 In any year of the period 1978-2004, the population figures implicit in the aggregate and per capita posteconomic census household consumption data differ from the official population statistics by less than 1 percent in the case of the total population and the rural population, and by less than 5 percent in the case of the urban population (with a maximum difference of 4.5 percent in 1978 and otherwise mostly an approximately 2 percent difference). For the official population statistics see the Labor Yearbook 2007, p. 3. Carsten Holz (2004a) discusses the two sets of population data-those used by the NBS in deriving the (earlier) household consumption data and those in the Statistical Yearbook - and points out the rise in consumption values that would follow from adopting the latter (as now done by the NBS, in the 2006 benchmark revision). NBS (2007, p. 92) describes the change from “village citizen” (nongcun jumin) and “city citizen” (chengzhen jumin), with the distinction based on agricultural vs. non-agricultural household registration, to "village population” (nongcun renkou) and "city population” (chengzhen renkou), with the distinction based on (permanent) residence, as in the fifth population census.

38 These cover purchases by households and other social entities in retail transactions. For details, see Carsten Holz (2004a) and NBS (1997). These retail transactions are difficult to capture in their totality. The NBS is reported to have gradually (zhubu) switched to the sales of commercial units as the variable on which to collect data. Since 2003, it has reportedly dropped the direct retail sales of consumer goods by factories from the concept of "social 
retail sales." In addition, or as consequence, the two categories "manufacturing” and "agricultural production" within the social retail sales measure were dropped. (Zhongguo tongji, no. 1, January 2003, p. 15)

39 The different types of government departments are: (i) legal-person public institutions (shiye faren danwei), (ii) legal-person (public) agencies (jiguan faren danwei), (iii) legal-person mass organizations (shehui tuanti faren danwei), and (iv) urban and rural neighborhood committees (cunweihui, juweihui).

40 A rationale for the NBS to knowingly provide underestimated values of government consumption is that if the NBS had reported accurate government consumption, expenditure approach (total) consumption and thereby GDP would have been much larger. Consequently, expenditure approach GDP would have significantly exceeded the official production approach GDP value.

41 At the provincial level, on the other hand, net exports are likely to be obtained as residuals. That in turn requires inventory investment to be estimated rather than to be obtained as residuals. In the early 2000s, before the 2006 benchmark revision of national values, the (pre-economic census) summed provincial value was many times the national value of inventory investment (in 2003, forty-one times, and in 2004 fourteen times, Table 3).

42 The 4.4 percent upward revision to 2004 gross fixed capital formation appears to be relatively small, but because gross fixed capital formation accounts for 41 percent of expenditure approach GDP, it is a large absolute amount. Presumably, part of the 4.4 percent increase consists of expenditures on computer software that are now supposedly consistently counted as gross fixed capital formation (Xu Xianchun, 2006a, p. 18). Otherwise, it is not clear where the increase comes from; possible explanations include a redefinition of the term "gross fixed capital formation" or simply a convenient adjustment so that expenditure approach GDP is close to the post-economic census production approach GDP value.

43 Although rural and urban per capita real growth rates fell, the economy-wide per capita real growth rate could rise because of the shift of rural to urban population in the 2006 benchmark revision. For the rural (urban) population, the difference in pre- and post-economic census real growth rates is not uniformly of the same sign in all years (Table 8).

44 For both pre- and post-economic census data, real growth rates of aggregate household consumption (total/rural/urban) differ from per capita real growth rates of household consumption (total/rural/urban) because real growth of aggregate consumption reflects growth in real consumption per capita plus population growth.

45 Prior to the economic census, total household consumption, derived from the value of total retail sales, came first (with some additional, separate rural and urban data), the breakdown of total household consumption into rural and urban values second. Rural and urban (aggregate or per capita) real growth rates are unlikely to have ever been aggregated into real growth rates of total (aggregate or per capita) household consumption.

46 Exceptionally, the new real growth rate for 2002 is 1.1 percentage points higher than the original one (Table 8), which could be due to pre-economic census revisions to the most recent year for which data were published in GDP 1996-2002, or to post-economic census intentional non-trend adjustments to the data of the most recent years.

47 The changes to deflators in 1998 and 1999 match well the reduction in the official 1998 real growth rate by 2.0 percentage points and the increase in the 1999 real growth rate by 2.3 percentage points. 1998 was the year for which researchers suspect official (upward) misreporting of official GDP growth; the ex-post downward reduction of real growth in gross fixed capital formation works in favor of this argument.

48 Details on rural and urban consumption components, necessary for any attempt to replicate the NBS compilation of household consumption, are available as summed provincial values for 1978-1995/1996/2002 in GDP 1952-95, GDP 1952-96, and GDP 1996-2002. Beginning with the Statistical Yearbook 2007, a national breakdown of rural and urban consumption by components has again become available, for the years since 2004 . ${ }^{49}$ Zhongguo tongji, no. 7, July 2000, 18. The Statistical Yearbook reports only the data compiled by the rural survey teams. In all three cases, reported income is likely to underestimate actual income (Zhongguo tongji no. 10, October 1999, 20f).

50 Part C of Table 6 shows that pre-economic census summed provincial tertiary sector value-added in 2004 falls eight percent short of post-economic census national tertiary sector value-added; it exceeds the pre-economic census national value by 37 percent (Part B of Table 6).

51 Summed provincial production approach value-added equals summed provincial income in all years since 1993, both for the pre-economic census data (as published in the Statistical Yearbook series) and for the post-economic census data (as published in GDP 1952-2004 and in the Statistical Yearbook since the 2006 issue). 
52 Income data of 2003 are from the Statistical Yearbook 2005, p. 62, and of 2005 from the Statistical Yearbook 2006, p. 67.

53 For the newly found production approach value-added for 2004 of 2300.24b yuan see the Statistical Yearbook 2006, p. 57, vs. 2005, p. 51; for the summed provincial operating surplus see the Statistical Yearbook 2006, p. 67, and 2005, p. 62.

54 The latter can be disaggregated into industry vs. the remainder, with industry accounting for a 1.65 percentage point drop, which the authors, in turn, attribute to reform of state-owned enterprises ( -1.00 percent), increased monopolization (-0.49 percent), and other factors (-0.16 percent).

55 Xu Xianchun (2006, p. 17) perhaps hints at the reason for avoiding revisions. He explains that the new treatment of financial sector value-added has been on the agenda for a long time, but the resulting large change in the value of financial sector value-added would have created a statistical break that would have been "not easy for the relevant departments and society to accept," while retrospective revisions of earlier data require a suitable opportunity, "otherwise everybody disapproves.” The values of China's official statistics thus at least partly reflect popular expectations.

See, in particular, Xie Haiqiu and Zhang Lihua (2006), who suggest that in their locality, Hunan Province Zhuzhou Municipality, GDP may well be eight percent higher than the economic census suggests. Liu Xiaoyue (2006) reports on problems in data collection at the lower tiers in general, including in censuses.

57 Tellingly, the Statistical Yearbook 2005, (p. 55), shows a detailed tertiary sector breakdown for 2003 (and 19972002) — agricultural services being one subsector - with aggregate tertiary sector value-added in this table identical to the tertiary sector value-added provided in the GDP table (p. 51). In contrast, the Statistical Yearbook 2006 (p. 61) shows a detailed sectoral breakdown for the whole economy in 2004-agricultural services not being included in the tertiary sector-with primary sector value-added and tertiary sector value-added 2.2 percent higher and 0.7 percent lower, respectively, than the corresponding values in the GDP table (p. 51). By the following year (Statistical Yearbook 2007, pp. 57, 65), the discrepancy between the two tables had disappeared.

An alternative explanation for changes to the primary sector value-added could be revisions due to the 2006 agricultural census (which may have been integrated into the 2007 release of data that carries the noted revisions). The exactly corresponding adjustment to tertiary sector value-added would then have to be explained by a NBS choice not to revise aggregate GDP but to subtract the newly found agricultural value-added from some other sector, and the tertiary sector, with the low reliability of the data covering some of its subsectors, then being the sector to balance the additions to primary sector value-added.

58 The Statistical Yearbook 2008, p. 44, also provides real value-added in base year prices for six exhaustive tertiary sector subsectors in 1978 through 2006.

59 The official sectoral real growth rates themselves are still Laspeyres volume indices at constant base year prices, given that the official real growth rates are obtained from sectoral volume indices which have output priced in base year prices. A series with output priced in, say, previous-year prices is not available.

60 The sectoral weights of the Törnqvist index are the geometric means of previous-year and current-year nominal sectoral shares.

61 Real growth rates of inventory investment (published) and of net exports (not published) are problematic in that when one year's values are close to zero, growth rates of this and the following year can be extremely large. (The NBS does not publish real growth rates of inventory investment in 1962 and 1963; in 1962, inventory investment was near-zero.) The volume series (not published) are still meaningful.

62 Using a Törnqvist index instead of a Laspeyres volume index at constant base year prices yields similar results for consumption but not for gross capital formation. A real growth rate of aggregate household consumption calculated as a Törnqvist index of the rural and urban real growth rates is up to 0.4 percentage higher if preeconomic census data are used, and up to 0.5 percentage points higher if post-economic census data are used; the only year in which the official household consumption real growth rate is below the calculated one, by 0.2 and 0.1 percentage points in the two sets of data, is 1996. The arithmetic mean of the annual differences between the Törnqvist index and the official real growth rate of household consumption in 1979 through 2002 is 0.1 percentage points for both sets of data. Similarly, real growth rates of household consumption and government consumption add up well to the real growth rates of total (final) consumption, with at most a 0.2 percentage point discrepancy in any year, and no discrepancy on average in the years 1978-2002/2004 (using either pre- or post-economic census data). 
The Törnqvist index of the real growth rates of gross fixed capital formation and inventory investment is significantly higher than the official real growth rates of gross capital formation, with several percentage points differences in some years and an average annual difference of 0.8 or 0.7 percentage points (1978-1999 using preeconomic census data, with no values on inventory investment real growth rates for 2000-2002, 1978-2004 using post-economic census data).

63 The Statistical Yearbook, starting with the 2007 issue, reports the percentage contribution of the three components consumption, gross capital formation, and net exports to the (unpublished) absolute real increase in expenditure approach GDP for the years since 1978. It also reports the product of these percentage contributions and the production approach real GDP growth rate, which yields approximate real growth rates for each of the three components (approximate because the second term is production approach real GDP growth and not expenditure approach real GDP growth). The thus derived real growth rates for consumption and gross capital formation do not match the through 2004 separately published real growth rates of consumption and gross capital formation. Real (volume) series of all expenditure components would be needed to explore the origin of the differences.

64 In contrast, if real growth rates (the denominator) were a Laspeyres volume index, the deflator would be $\frac{\sum p_{3} q_{3}}{\sum p_{2} q_{2}} / \frac{\sum p_{2} q_{3}}{\sum p_{2} q_{2}}=\frac{\sum p_{3} q_{3}}{\sum p_{2} q_{3}}$, i.e., a Paasche price index.

65 See, for example, NBS (1997), pp. 21-30, or Xu Xianchun (2000b), pp. $75 f$.

66 In the case of intermediate inputs for the different agricultural subsectors, up to 12 price indices are relevant. No details are provided on the price index for GOV, the "agricultural products production price index" (nongchanpin shengchan jiage suojian zhishu). For agricultural services, the procedure is to deflate nominal value-added by the service component of the rural CPI.

67 For details, see, for example, Xu Xianchun (2000b), pp. 77-80, or the GDP Manual, pp. 67-74. For the data since 2004, see NBS (2007).

68 For example, Angus Maddison (1998) states, without presenting evidence, that "there are two official price indices which provide a more realistic measure of the pace of inflation" than official implicit deflators; these are the producer price index for industrial products (in official terms, the "ex-factory price index of industrial products"), and the retail price of industrial products in rural areas (p. 140); Harry Wu (2000) provides a more detailed argument. Harry Wu (2000) proceeds to estimate alternative real growth rates based on output quantities; his results are reported in an earlier working paper of his and are used by Angus Maddison (1998). In Carsten Holz (2006a, including the appendices), I question the rationale for abandoning the official data and argue that the alternative real growth rates based on output quantities are likely to underestimate real growth severely.

69 See Xu Xianchun (2000b), pp. 23-26. The applicable value-added tax is derived from the value of value-added tax actually paid, taking into consideration timing (time of sales when the value-added tax accrues vs. time of production) and corrections for tax reimbursements (for example, in the case of exports) and value-added tax paid on bought-in products. Small enterprises may simply apply a flat six percent rate to sales revenue (which not necessarily equals value-added) to obtain their value of value-added tax. The GOV of some small enterprises may be approximated with business revenue. (For the complications of the statistical break in the GOV series in 1995, see Carsten Holz and Yi-min Lin, 2001a and 2001b.) NBS (1997), pp. 32-7 provides similar explanations; the DRIEs at that point in time were defined differently and this source provides further details for the case of the non-DRIEs. The GDP Manual, p. 21, states that the ratio of value-added to GOV which is to be applied to the non-DRIEs' GOV is provided through sample surveys of the (NBS's) enterprise survey teams. For the years since 2004, NBS (2007, pp. 16f.) procedes along similar lines as Xu Xianchun (2000) and NBS (1997); the economic census provides census data for 2004 so that no mentioning of surveys is made.

${ }^{70}$ In the early 1990s, the constant-price list applied to all industrial enterprises at the township level and above. It explicitly did not apply to village and below village-level enterprises or to the urban or rural self-employed (NBS, 30 Sept. 1990). The constant-price list consists of two parts. One is a national list that covers approximately 1500 industrial products in 45 categories. The national list reprinted in NBS (1995, pp. 1055-1132) does not contain prices; it names, for each category, a government department or company that presumably determines the price. The second part consists of a supplemental list at the provincial level; it may not substitute for or replace items included in the national list, and it is to be filed with the NBS. A number of special cases is discussed in the regulation (NBS, 30 Sept. 1990). For example, if an enterprise's product differs in specification to one included in the list, then the 
constant price of that enterprise's product is obtained by the local statistics department based on the product's 1990 relative price compared to the item included in the list. Newly introduced products are to be reported up to the relevant government department, which is to determine the constant price; with approval of the local statistics department, a temporary procedure is to use as the constant price the ex-factory price when the product is first produced.

71 The collection of industry-wide product quantities would require massive guesswork by lower-level statistical officials (and is contradicted by the findings of Carsten Holz, 2003). Considering the number of private and collective-owned small enterprises in the countryside, it would seem impossible to compile records of their types of products, their output quantities, and the quality/specifications of their products. Furthermore, for small enterprises to report constant price output, they need to know the constant prices. It appears not the case that millions of copies of the constant price manual are flooding the countryside - it is not even publicly available. It may, in fact, simply consist of a series of sector-specific publications.

72 The Statistical Yearbook 2005, exceptionally, on the first page of the industry section, reports value-added real growth for the DRIEs and various sub-groups of the DRIEs for 2004.

An exception is industrial GOV in nominal and real terms. Following the 1995 industrial census, GOV values of 1991-1994 were revised downward (but industrial value-added was not revised).

74 It would seem a natural choice for the NBS to use the output of the until 1997 industrial enterprises at the township level and above to derive real growth rates and implicit deflators for industry, as these data are available since 1978. The 1990 constant price regulation issued by the NBS (30 Sept. 1990) suggests as much. The DRIE deflators, in contrast, are only available for the years since 1994. The deflator of the (industrial) enterprises at the township level and above comprises all DRIEs (pre-1998, the industrial enterprises with independent accounting systems at the township level and above) plus industrial enterprises at the township level and above without independent accounting system. In 1995, for example, the DRIEs accounted for 96.86 percent of the GOV of all industrial enterprises at the township level and above. Data on industrial enterprises at the township level and above were discontinued after 1997, with similar tables in the Statistical Yearbook series now covering the DRIEs only.

75 The counterpart to an underestimated deflator is an over-estimated real growth rate.

76 The deflator of industrial GOV appears a better fit than the deflator of GOV of the DRIEs. But the NBS is likely to have price data only for the DRIEs, not for all of industry. This would then suggest NBS adjustments to a deflator derived from DRIE data to arrive at a new deflator for GOV.

77 GOV is deflated using the ex-factory price index and intermediate inputs are deflated using the purchasing price index of raw materials, fuel and power. The difference of the two deflated series equals real value-added. Combining this real value-added series with (pre-economic census) nominal value-added in the NIPA yields a final value-added deflator. Since 1987 (but not in 1985 and 1986), this "double deflator" matches the value-added deflator in the Statistical Yearbook 2005 well.

78 In contrast, prior to 2004, household consumption was deflated using the corresponding components of the CPI with a number of exceptions, of which the major ones are: rural self-produced self-consumed production was deflated using the corresonpding agricultural GOV deflator, owner-occupied housing using the investment in fixed assets price index, financial services using the investment in fixed assets price index and the retail price index, and urban consumption of agricultural sideline products using the agricultural products market transaction price index (nongmao shichang nongchanpin chengjiao tiage zhishu). See NBS (1997, pp. 157-61).

79 The Industrial Yearbook 1993 also provides employment data for these sectors in these years in the same table. In addition, the Statistical Yearbook series reports data on 13 non-exhaustive sectors for 1980-84 and then on an increasing number of sectors in subsequent years.

80 The Statistical Yearbook 2012 (p. 332) reports price indices by industrial sector for 2008-2011 acording to GB2002 (i.e., as in the industry section of the Statistical Yearbook, the switch to GB2011 has not yet occurred in the data).

81 For details on the statistical breaks in industry data, see Carsten Holz (2013).

82 The reasoning for why the values of the three main economic sectors in 1990-2004 follow GB1994 (with the one exception of the classification of agricultural services) is the following. First, the aggregate tertiary sector values as well as the two tertiary sector subsector values in Appendix 1 match those of the detailed tertiary sector classification in Appendix 6 (below), and the latter with near certainty follow GB1994 (as explained below), except 
that agricultural services are always included in the tertiary sector in contradiction to GB1994 (and GB1984 and GB2002). Second, with the aggregate tertiary sector values following GB1994 (except for the inclusion of the agricultural services), and the secondary sector likely to be consistently defined between GB1984 and GB1994, the primary sector values must comply with GB1994 (except for the exclusion of agricultural services). The secondary sector appears to be identically or near-identically defined in GB1984 and GB1994; at worst, it has experienced extremely minor changes, such as possibly in construction where a slight reclassification took place that, however, appears to not have affected non-secondary sectors (or industry).

83 The preface to the NIPA section (Statistical Yearbook 2007, p. 56) makes the adoption of GB2002 for all years explicit.

84 Three independent considerations otherwise suggest the match with GB1994. First, all individual subsector labels used in the statistics match those of GB1994, except for the additional listing of agricultural services. With the original regulation on GB1994 not available, GB1994 is inferred from the employment classification used in the 2000 population census data, where agricultural services are included in the primary sector. If GB1994 were to include agricultural services in the tertiary sector (in contrast to the 2000 population census data), then the description of the changes between GB1994 and GB2002 in Zhongguo tongji, which is particularly elaborate for the primary sector, should mention that the agricultural services in GB2002 moved from the tertiary to the primary sector, which it does not. That, in turn, implies that the classification of agricultural services is identical in GB1994 and GB2002. Second, the compilation of value-added in the production approach is explained in NBS (1997, pp. 21137); this source explicitly follows GB1994 (p. 9) and its sectoral labels match those of GB1994, yet this source also does not list agricultural services with agriculture, but as a separate sector after construction and before the other tertiary sector subsectors. Third, the tertiary sector subsector values reported in Appendix 6 for the years since 1990 were first published in the Statistical Yearbook 1998, i.e., at a time when GB1994 was in effect.

85 The fifth subcategory of the primary sctor is titled "water conservancy" (shuili ye) and covers water conservancy facilities and projects in the areas of irrigation, water reservoirs, dams, sluices, river control, and flood prevention, as well as all water conservancy work units and water and soil preservation units. The sixth subcategory is titled "services for farming, forestry, animal husbandry, fishery, and water conservancy" or, in abbreviated form, "agricultural services," with water conservancy only appearing in a sub-subcategory of "other services for farming, forestry, animal husbandry, fishery, and water conservancy;” the coverage of water conservancy in this sixth subcategory thus is limited to "other" services.

${ }^{86}$ A small issue is that the last decimal of most tertiary sector subsector values is zero through the early 1970sexcept for the two "material production sectors" of 'transport and communication,' and 'commerce and catering'which suggests that these values for the early years of the People's Republic of China may not be particularly reliable.

87 'Transport and communication' in GB1984 as well as in GDP 1952-95 (preface, p. 2) covers transport, post and telecommunication services, but in GB1994 transport, storage, post and telecommunication services (and in GB2002 transport, storage, and postal services). 'Commerce and catering' in GB1984 as well as in GDP 1952-95 (preface, p. 2) covers trade, public catering, material supply and marketing cooperatives, and storage, but in GB1994 wholesale and retail trade and catering services (and in GB2002 wholesale and retail trade).

88 Checking tertiary sector subsectors in the two sources for 1995, several individual subsectors match fully. These do not: in GDP 1952-95, social services with $179.10 \mathrm{~b}$ yuan, public facilities $25.40 \mathrm{~b}$ yuan, and science (which includes geological investigation and prospecting) $175.53 \mathrm{~b}$ yuan, adding up to $380.03 \mathrm{~b}$ yuan; in the Statistical Yearbook, the same residual of 380.03b yuan comprises agricultural services with $11.58 \mathrm{~b}$ yuan, geological prospecting with $25.33 \mathrm{~b}$ yuan, social services with $154.64 \mathrm{~b}$ yuan, health care with $48.32 \mathrm{~b}$ yuan, education with $112.45 \mathrm{~b}$ yuan, and science with $27.71 \mathrm{~b}$ yuan.

89 The subsector labels follow GB2002 and the data show no inconsistency at any point in time (including for the two subsectors 'transport, storage and post,' and 'wholesale and retail trades'). There is no break around key years such as 2004 or 1990, and the values are consistent in comparison to those of related sectors in the earlier classifications and earlier publications.

90 The provincial data in GDP 1952-2004, in contrast, limited to 1993-2004, follow GB1994. 